
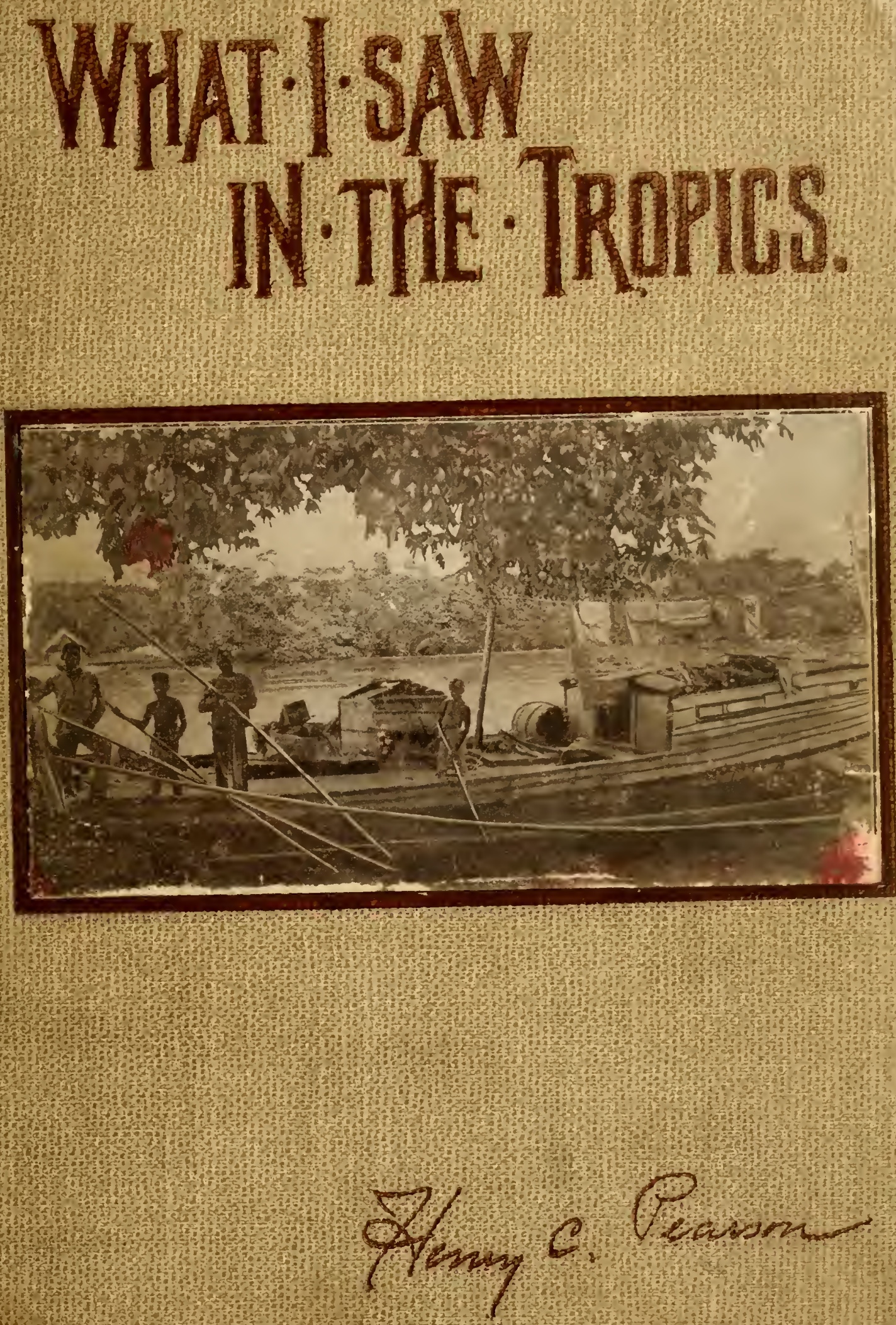


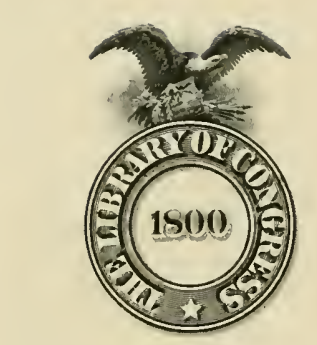

$$
\begin{aligned}
& \text { (lass } S B_{291} \\
& \text { bow I I } 4 P_{33}
\end{aligned}
$$

Coprighth ¿".

(OPJTICHT DEPOSIT. 





\section{WHAT I SAW \\ IN THE \\ TROPICS}

A RECORD OF VISITS TO CEYLON, THE FEDERATED MALAY STATES, MEXICO, NICARAGUA, COSTA RICA, REPUBLIC OF PANAMA, COLOMBIA, JAMAICA, HAWAII

BY HENRY C. PEARSON

Editor of The India Rubber World

NEW YORK

THE INDIA RUBBER PUBLISHING CO.

35 West 2 IST STRERT

1906 


\begin{tabular}{|c|}
\hline 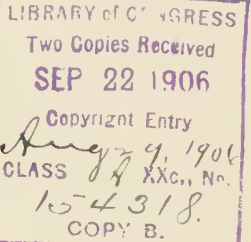 \\
\hline
\end{tabular}

COPYRIGHT, 1904, BY

The India Rubber Publishing Co.

COPYRIGHT, 1906, BY

Henry C. Pearson

$\therefore \vdots \vdots$ 


\section{PREFATORY}

THAE to write a preface, in fact I always resolve not to, and then 1 do it. When I brouglit out "Crude Rubber and Compounding lngredients," a captious friend complained that it was too matter of fact,-that it "lacked inmagination." As it was practically a dictionary of methods of rubber manufacture, I did not care, that is, I did care, but dicln't show it. This book is different. The story of rubber planting is most romantic and at the same time as a whole is sound and successful. I should like to stop a bit just here to say to a lot of good fellows who smiled at my predictions ten years ago-"I told you so." But they have forgotten, and if they haven't.- what's the use?

Starting again, this book is not a scientific treatise. It contains the personal experiences of the anthor "dished up in his inimitable style" (note the quotation marks), in his search for rubber planting information in the tropical world.

As a scientific treatise it may be scorned by some intellectual ones who have a string of letters following their names-(I wish I had them mrself) but whose attenuated digestive organs preclude the possibility of wedding fun with fact.

At all events the statements regarding rubber made herewith are facts and can be gambled on. As to my personal experiences and adventures, think of them as you like.

Another word-I want to thank planters the world over. for their interest and hospitality but then they know that too, and if I called them all by name here this book would contain a three hundred page preface. 



\section{CONTENTS}

CEYLON AND FEDERATED MALAY S'TATES

FIRST LETTER.

From NEW YORK TO CEYLON . . . . . . . . . . . . .

Some Experiences of the Journey; Opinions of English Manufacturers Regarding (eylon Rubler; Points of Interest in the Tropies: Peantiful Ceylon: A lisit to Typical Hevea Plantations.

\section{SECOND LETTER.}

Results of Experiments at the Royal Botanic.l, Gindexs . Growth of Hevea and its Yield at Varions Iges; Canker Fingus ancl its Treatment: Plantation Scenes.

\section{THIRD LETTER.}

A Visit to the New Experianent Station, Then to Culloden

Tapping Rubber Trees at Peradeniya Garden: Ficus Elastica Seventy-five Years ()1d; Prospective Increase in Planting;

Rainfall and Labor: Some Incidents of Travel; Library of

Singalese Sacred Literature: The Para Output from Cerlon: The Weeding of Crops in the Island.

\section{FOURTH LETTER.}

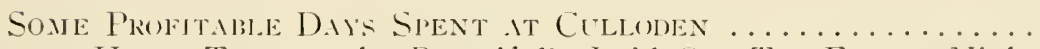
Hevea Trees at the Beautifully Laid Out Tea Estate; Night

Tapping: Results of an Experiment in Scraping the Onter

Bark from the Trees: An ()il made from Seeds of The Rubber Tree: A Rubber Drying House and Methods of Coagulation: Some Valuable Information Gleaned from Visits to ()ther Rubber l'lantations.

\section{FIFTH LETTER.}

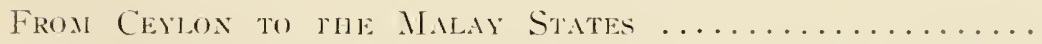
Arrival at Singapore: A Word About the Seat of Government: Visit to Royal Botanical Gardens: Hevea Kesponds to Cultivation Here: Phenomenal Crowth: Distance Planting: Castilloa and Ceara Less Promising A Visit to Chinese Merchant Quarters W'here Gitta Percha is I'repared for European Markets: Processes Watched with Interest: From Singapore to Selangor. 


\section{CONTENTS}

\section{SIXTH LETTER.}

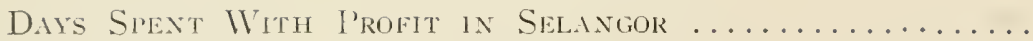
Rubber Plantations at Klang: Distance of Planting: Age at Which Hevea Trees Yield: The Labor Question; The Chinese as Rubber Planters: The Selangor Rubber Company: Return to Singapore and Departure for Hong Kong.

\section{ISTHMUS OF TEHAUN'TEPEC \\ FIRST LETTER.}

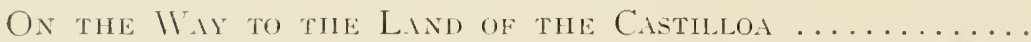
The Mining City of Zacatecas: Queretara Where Maximilian Was Exccuted: Mexican Opals: The Eternal Snows of Popocatepetl and Ixtaccihuatl: From the City of Mexico to Achotal: Experiences at the Latter Town: First Sight of Cultivated Rubber.

\section{SECOND LETTER.}

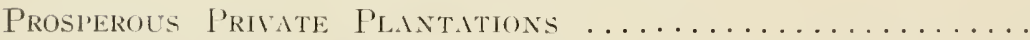
Careful Study of the Situation Proved to lnvestors that Rubber Would be More Yrofitable than Coffee: Results of Planting in Favorable and [nfavorable Conditions: Continual Tapping Showed Late.t Given Out by All Trees; Knowledge of Clinatic Conditions Nécessary to Successful Planting; La Junta; The Laborers.

\section{THIRD LETTER.}

A Grasp on the Rubber Planting Situation ............ Clearing and Purning by Contract; Danger from Fires; Gathering Castilloa Seeds: Costly Seed Failures: The Journey to Coatzacoalcos: Morning Glory Vines: The l'roblem of Tapping and Preparing for Market.

FOURTH LETTER.

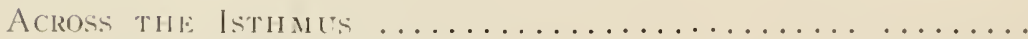

Tiews of Many Plantations: last Tracts of Land Needing Only Irrigation to Make Them Valuable: Mexican Laws: Animals and Insects of the Temperate \%one: Manner in Which I'lantations are Taxed: The Cow Pea and Velvet Bean Which Should Receive the Attention of Rubber Growers. 


\section{NICARAGUA}

Rubber Interests in Centr.l. America ...............

Witnessing a Waterspout: Through the Lagoons to the Rubber Plantations; The Nanhattin Plantation: Too Much

Water Detrimental to Castilloa: "The Rainfall : Sim 1rons" Rubber Groves and Cukra Plantations: Careful Tapping: Four Hundred Thousand Castilloas in This Vicinity a Conservative Estimate: $A$ seale that Affects the Rubber Trees: Samples Brought to United States and Examined at the Connecticut Agricultural Experiment Station at New Haven: Letters from State Entomologist. Connecticut, and Acting Chief of Bureau of Entomology at Washington: Treatment Suggested for Extermination of the Pest.

\section{COSTA RICA}

A Plantation of Oyer One Hundred Thousand Castilloas Bananas the Chief Product of the Country Interplanted with Rubber in Many Instances; Proper Drainage the Only. Salvation for Rubber Trees: Watery Later: Interest in Rubber Planting in Costa Rica Dates Back About Twelve Years: Some l'lantations That are Flourishing.

\section{PANAMA}

\section{FIRST LETTER}

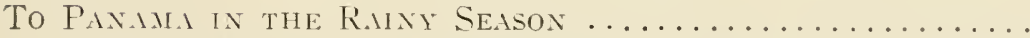
Colon: Along the Panana Canal: Panama City: Toboga Island: Quebro Outlaws: Almost Vrecked: Ashore at Last: Castilloa Growing Within One Humbled Feet of the Shore; Interesting Stories of the Pioneer.

\section{SECOND LETTER}

Rovghing IT

Camp Rio Negro; Castilloa Groves; Birds, Animals, and Reptiles: Trips of Exploration; Coagulating Rubber with Amole Juice: Native Rubber Gathering: P'rocess of Tapping and Tools L'sed: Trails Cut in Every Direction Followed by Long. Hard Tramps. 
THIRD LETTER

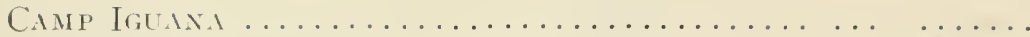

The Forest I'rimeval; lices and Rubber; A Land Without

La川: Breaking Camp: Mountain Clinbing; Plantation

Las Margharitas: On lioard Onartos Hermanos; Panansa. Colon, and New York.

\section{COLOMBIA}

IMPRESSIONS OF THE CONNTRY

Journey from the Fort of Colombia to liarranquilla: Amusing Hotel Experiences in That City; The Stay in Cartagena; Little Information to be Gained About Rubber;

Meeting Mr. Granger, Lnited States Consular Agent at Quibdo; His Interesting Account of the Reason for the P'resent Lack of Interest in Rubber Planting: His Prophesy for the Future Based upon

Present Well Founded Indications.

\section{JAMAICA}

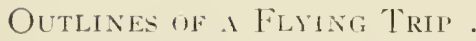

A VIord Concerning the Island of Jamaica; Information from the Departtment of Agriculture: A V isit to Castleton

Gardens: Something thont the Rubber Produced There and the Conditions Attending it: Hope Gardens: Hevea and Castilloa: The Milk Withe.

\section{HAWAII}

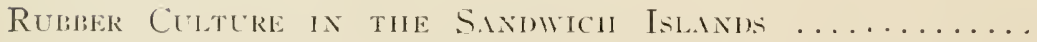
The First Sight of Hawaii ; A Pit of the History of the Sanctwich Islands; Temperature, Crops, etc.; Prospects for Rubler Growth; lirst Rubber Plantings: The Nahiku Rubber Company, Linnited; Principal Planting Done by Lnited States Settlers. 


\section{FIRST LETTER.}

Crossing tine Atlantic-English Manufacturers and Cestox Putrber-On Bontd the Hialayi-Stromboli-Port Shid axd tile Stez Canal-Tine Red Sea and Aden-Beiutifll Cejlon-At the Galle fice Hotel-Singalese, Tamils and Chinese-Quant Custons-Director Willis, of Peradenisa and Heneratgoda-The Oldest Plantations of Hefen-Iy a Blllock "Hackery" to HeNeritgoli Girnexs.

those who are interested as to why I chose the Leyland liner. Deronian, to carry me across the Atlantic at the leginning of my journey toward the Far East. I leeg to explain that she is a big, roomy, seawortly craft of I r,ooo tons, that there were only six passengers all told, and although she carried some eight hundred cattle, they did not appear on the deck, or at table, nor would one have dreaned of their existence, once they were driven aboard. The ten days that were occupied in crossing, spent chietly on the promenade deck playing quoits with the ship's doctor, put me in fine trim for the brief view of Liverpool and London that I had before the alleged train de lute bore me to Marseilles, to join the $P$. and O. steamship, the Himalay'a. My stop in England was only long enough to allow me to see a few of the leading rubber mantfacturers, and get their ideas as to the value of the new Pará rubber that Ceylon planters are sending to that market.

One who has probably used as much of this rubber. or more than any other, summarized his experience as follows: "It shrinks on the arerage about $1 .+$ per cent. I use it successfully in all grades of fine work, inchuding cut sheet, but do not like it for cements. It stands all tests after vulcanization-compression, stretch and return, oils, etc., just as well as fine Pará, and is perfectly satisfactory."

Another detailed the results of his own experiments thus: "This is a general summing up of the practical results, obtained from approxinnately two tons of rubber, from about twenty different plantations. The irregularity in quality is very great, varying from tough elastic gum, apparently equal to Manáos Pará, to soft. sticky short rubber, with little more elas- 
ticity than recovered rubber. This irregularity $I$ find in all the forms of pancakes, whether thick or thin, translucent or opaque, except those which have been smoked; which, whether owing to the smoke or some other reason, have in the lots (from three separate plantations) which I have tested, proved even in quality throughout. I have been favored by one plantation with unsmoked samples (separately treated and marked) from eighteen year old trees, and from young five year old trees. Each of these samples proved regular throughout, but the quality was very different. that from the old trees being tough and very elastic, while that from the young trees was soft and green. It appears to me, therefore, probable that the irregularity I have noted in the quality of shipments may arise from the varying ages of the trees, and that until they have reached absolute maturity, the latc.r of one season's planting should not be mixed with that of younger or older trees, but that each year should stand on its own merits to attain regularity in quality. The smoked samples may have come from old trees only; and the smoke perhaps had nothing to do with the quality. This want of regularity utterly shuts out Ceylon rubber from fine work, such as thread, cut sheet, bladders, etc., and as the strength of a chain is but that of its weakest link, it cannot at present, for general work, be classed higher than the good mediums. For the special purpose of making cement, however, it has found a place for itself on account of its extreme cleanliness, and the very convenient form of the pancakes in which it is shipped, practically ready for the naphtha bath. I believe in a great future for rubber planting, properly carried out. It might be (lone by the government forest department, and the trees rented when old enough."

Thus the only "ont" about the rubber, from the viewpoint of the user, seemed to be the presence of immature, or partly cured gum, something to be expected when the fact is remembered that the plantations are young and the planters without long experience in gathering or preparing for market. The added fact that it brings the highest price in the market led me to believe that $I$ had before ma a most interesting series of plantation visits, once I shculd reach Cerlon and the Federated Malay States.

As I saicl, therefore, I took train at Dover, crossed the channel. landed at Calais (so called from the way they handle one's luggage), shivered all the night in the absurd little French train de lute, and finally. arriving at Marseilles, stepped aboard the steaner that was to be my home for nearly three weeks. In due course we left the granite quays, the shipping, and the splendid linestone cliffs of the lirenily port behind 
and settled down to the Mediterranean trip. Ne passed through the straits of lionifacio in the night, so that I had no chance to observe, or photograph, and the next morning we were out of sight of land. The day following we all started in to get aceuainted. I was the only Imerican aboard, the major part being English people who had interests in India, Ceylon, or Anstralia, and some even were going beyond to Hongkong and Yokohanna.

I had thought to do some writing on this voyage. but some kindly soul put me on the "amusements committee," ancl what with tournaments for deck (110its, cricket, ball, needle and cigarette races, etc., not to speak of two concerts, my time was pretty well taken up. My revenge

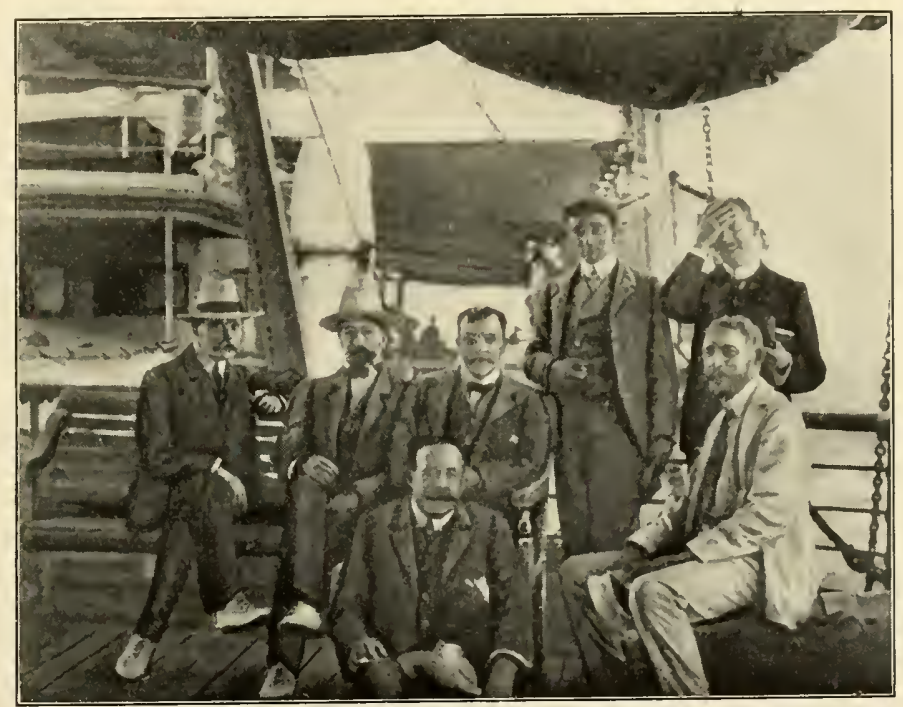

THE AMUSEMENTS COMMITTE.

[On H. M. S. "Himalaya."]

came with the concerts, however. I made a speech at each, relating various well known American stories as personal experiences, and they were most enthusiastically received. As the British are firmly convinced that all Americans are speech makers, it is well for those who propose to travel with them to prepare to be called upon.

On the night of November $2 \mathrm{I}$, we had a splendid view of the volcano of Stromboli, which gave us a veritable special exhibition. The night was moonless, and the sea as smooth as glass. About nine oclock we 
caught the first red glow of the crater, and two hours later we were near enough to dimly discern the outline of the cone shaped island mountain, and to see plainly the red lava torrents that tumbled down its sides and were quenched in the sea. We all staid up until the island was lost to sight, and left the deck only when a faint reflection on the gathering clouds was all there was left to us of one of the most impressive sights.

We passed the straits of Mycenae so early in the morning that none of us were up, and on Monday we saw Crete in the distance. By this time the boat had developed a pretty fair roll, but few were ill, and the deck games went on--that is, for the men. On Tuesday noon we were behind the breakwater at Port Said and surrounded by coaling scows, crowded by dirty Arabs who did the coaling with baskets. As the air was full

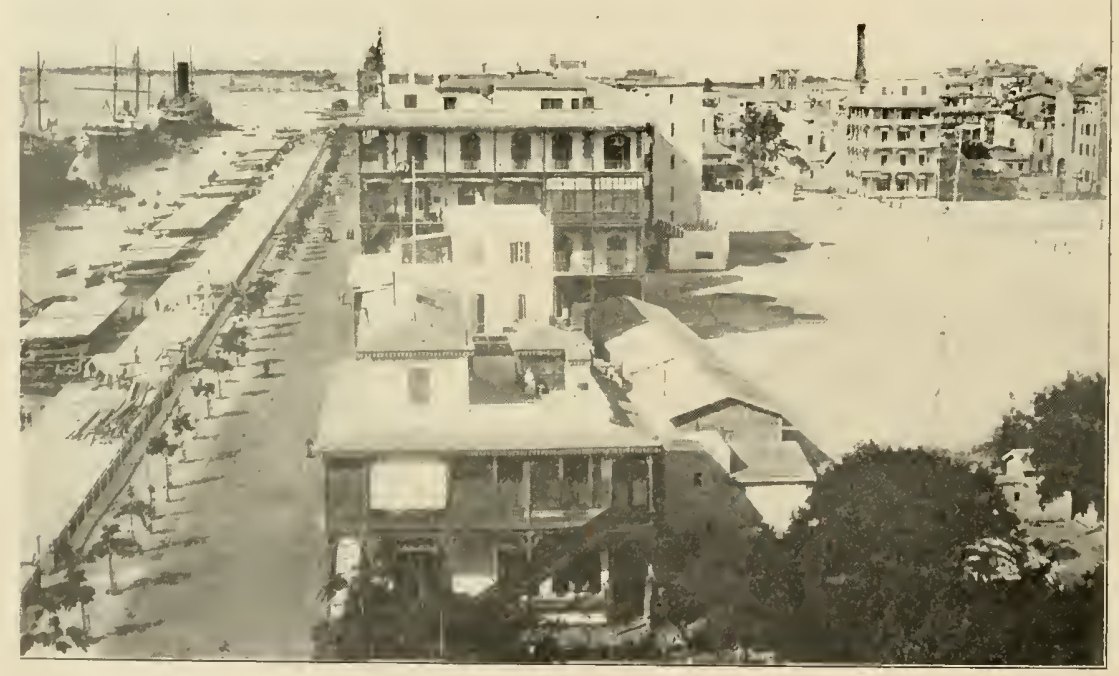

PORT S.IID WATER FRONT.

of coal dust a half dozen of us secured a boat and went ashore, spending the afternoon in roaning the sandy streets, followed by a crowd of beggars, jugglers, pox-pitted street venders, sellers of indecorous photographs, and all of the riffraff of the nastiest of all the cities of the Orient.

Port Said is built on soil, chicfly sand, that was dumped there during the excavation of the caral. It is a busy, hustling place, olue to the constant arrival and reparture of steamers. It has a fair harbor made 
by two breakwaters, that extend ont into the shallows, one 7,000 feet, the other 6,000 feet.

We expected to get away early the next morning. but the mail from brindisi being late, it was four v'clock in the afternoon before we enrered the canal. According to rules, we steamed at four miles an hour, tying up to the bank when another boat was met. As we passed by three during the night, this occasioned quite a delay. It was cool, and a light overcoat was necessary after the sun set, but we did not stay long on deck as botlı sand flies and mosquitoes were quite abundant.

In the light of our own American canal projects, it is interesting to remember that the Snez plan was entertained and dismissed as impracticable hy Napoleon I, who was advised by his engineers that the Red Sea was thirty-three feet higher than the Mediterranean, and later when M. de Lesseps had proved that the difference in levels was but six

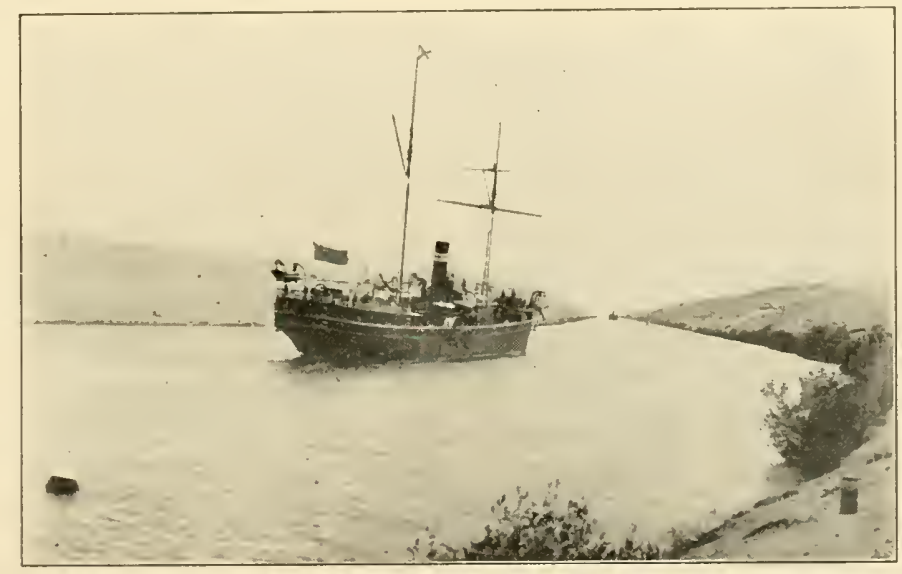

IN THE SLEZ CAN.IL.

inches, such an eminent authority as Rohert Stephenson declared the plan to be commercially unsound. There was also a rival plan bronght out for a 250 -mile canal from Alexandria to Suez. Nevertheless the great work was completed. It is one hundred miles long. only about one-quarter of it being artificially made, the rest traversing natural lakes such as Bitter Lake and Lake Timsah. The plan of the canal was for a depth of twenty-six feet, the bottom of the ditch being seventy-two feet wide and the top ahout three hundred feet. This was carried out in places. but where the digging was especially hard it is somewhat narrower. The canal shows a slight current, and slowly though the boats go through it. 
there is a constant crumbling of the sandy banks so that a force of steam dredgers is employed keeping the channel clear, nor is this work allowed to flag for an hour.

The next morning we were still hemmed in by sandy banks, and the scenery was not inspiring, being varied only by small stations about which clustered a few lebec trees, the big dredges and an occasional native boat with its huge yards and dingy sail. Passing both the old and the modern cities of Suez, we left the canal and were in the gulf of Suez. Here the water was of a marvelous blue, the sun brilliant, and the far off, lofty sand dunes, scored and seamed by winds and rain. showed wonderful effects in yellow, hrown, violet and purple. Here we began to get the warm weather. With Asia on our left, Africa on our right, and both in sight, a smouth sea and blazing sum, white flannel and duck suits soon appeared; the punkalss were started in the dining saloon, and the whole of the deck sharled by both top and side awnings. Wind scoops were also placed in the open ports, and we felt at last that we were in the tropics.

The next point of interest to be noted was the Daedelus shoal, from which our Captain broun once rescued one hundred and eighty souls. who, escaping from the wreck of their vessel, were gathered in a shivering crowd, waist deep in water.

We harl a further evidence of the genuineness of the hot weather the next morning at three oclock, when the order came to close the ports as the water was slopping into the cabins. How most of them stood it I don't know, but 1 took a blanket and went on deck, and even then it was stifling. At daybreak we passed the "twelve apostles," a dozen big rocks rising abruptly from the sea, a grim weather beaten row. It was near here that the Turkish govermment, after much pressure. erected fine light-houses furnished with the latsst illuminating devices, but after keeping them lit for two weeks, the lights went out and not a slimmer have they shown since. As navigation is a bit perilous hereabouts, and mariners need the lights, it is just as well perhaps, that I dicl not make careful note of the quartermaster's opinion of the unspeakable Turk, given as he tolil me the story.

The days were now long, hot, and a bit monotonous. Shut out as we were on the promenade decks by canvas walls, the peeps that we got at the sea showed a glare of light that was almost unbearable. The only relief was when a sudden drenching shower obscured the sun and we got glimpses of mountainous islands, distant peaks, and still more distant ranges. IV e were fortulate. however, in seeing the volcanic island Jebel 
Tair, and later Mocha, Mt. Sinai having been passed in the night. With a glorions setting of the smover Somaliand, we passed through the straits of Bab-el-1landel, ly the harren ishand P'erim, and the next morning cast anchor in the harbor at Aclen.

It must lave been two odlock in the morning when I awoke and found that we were at anchor. The somul that brought me to a sense of my surroundings, and the insufferable heat of the cabin, was the chanting of a gang of coolies who were warping a huge freight scow up to our steamer. Their song was the iteration of two phrases that sombled like "Esco darn ye! Perri go darn ye!" and with each "dlarn" they all gave a pull. Besides this, there was a constant chatter from a half humberl boatmen, that drove me on deck, where wrapped in a rug. and lying in the scuppers. I got a few more winks. Aden is as minteresting as it is mulhealthy. It is well called "the white man's grave," as hunclreds lie buried on its rocky slopes.

It is built on a flat, sandy, treeless plain, hemmed in by hills, ariel and harren to the last degree. It rains here regularly once in three vears, and the water is stored in huge tanks five miles away up in the hills. Anyone who wishes to enjoy a long cool drink, and then another. should seek this thirstiest of all thirsty spots. It was here that the passengers whose destination was India were transferred to another steamer. And sorry we were to have them go, for many friendships had been formed which were of the sort that shonld continue.

Here left, tco, a young man who had not only been my partner at reck quoits, but who harl given me much information alout America. Shall I ever forget the evening. just after our excellent course limner. when he said to me, with the kindest of intonations:

"Dont you miss the sweets (candy) between the courses?"

"What sweets?" was my bewildered query.

"Why, you know, in America, at a course dinner, they serve sweets after the soup, and the fish, and the entree, and right through the dinner."

I had no vivid remembrance of that custom myself. but his faith in the exactness of his information was so great that it would have been a sin to upset it, so I agreed that I was pining for chocolate creams after the consomme, and molasses candy as a chaser for the fish, and it made him my friend for life, for which I an exceedingly glad, as in spite of that one absurd idea, he was one of the finest chaps I ever met.

Speaking of the people one meets in distant lands, it is sad to say that one's own countrymen are often the biggest freaks. I met one of the freak sort later. He had not been in the smoking room ten minutes 
before he had told his whole history, and got every Briton and European there white hot by his comparisons, invidions and startling. In the midst of it I was pointed out to hin as a fellow countryman, and he tried to get me into the fight, but I balked. Then he started in to impress me with his importance.

"I come from Cod's country," he said. "but I've been all over everywheres. I used to be consul at $\mathrm{A} \longrightarrow$. I lecture, too. When I was consul at $\mathrm{A}$ - I often used to go aboard a man-of-war and lecture, sometimes for two or three hours, and I always got seven guns; what do you think of that?"

"Mighty poor shooting, so far, but they will get you some day," I saicl with conviction.

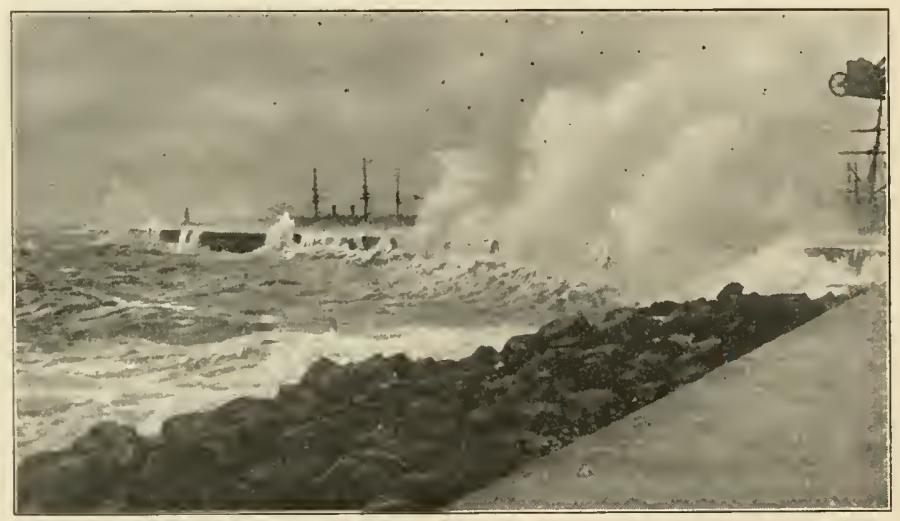

BREAKWATER AT COLOMEO, CEYLON.

After leaving Aden I was able to secure an upper deck cabin, which was much coo'er than those either on the main or spar decks. Now that we were in the Indian Ocean, the sea grew much smoother, and early in the norning. after a salt water bath, the men promenaded the deck in pajamas until eight o clock, after which ordinary clothes were required.

We now began to feel the breath of the monsoon. while the water tuok on an even bluer blue, and flying fish in shoals fled to right and left from the onrushing ship. The heaviest sort of showers also began to come with more or less regularity, the ship's officers came out in white duck suits, prawn, fish, and other currys appeared at dimer, and we knew that we were in the tropics.

() 11 the evening of December 5. We sighted Minecoi Island, a low lying. circular bit of land crowded with graceful cocoanut palns, and 
a well-known copra producing place. ()n the day following, at $1.15 \mathrm{in}$ the morning. we passed behind the great breakwater and dropped anchor in Colombo harbor, in the midst of a great fleet of passenger and tramp. steaners of all nations, native loats, lighters, etc. Most of the men aboard were on deck, although pajana-clad, and as the coaling was soon to begin, I went ashore, passed the little black customs inspector without difficulty, and, getting in a jinrikisha, was soon at the Galle Face Hotel and sound asleep in a big wide berl that seemed delightfully steady when contraster with even the comfortable berths of the Himalay.

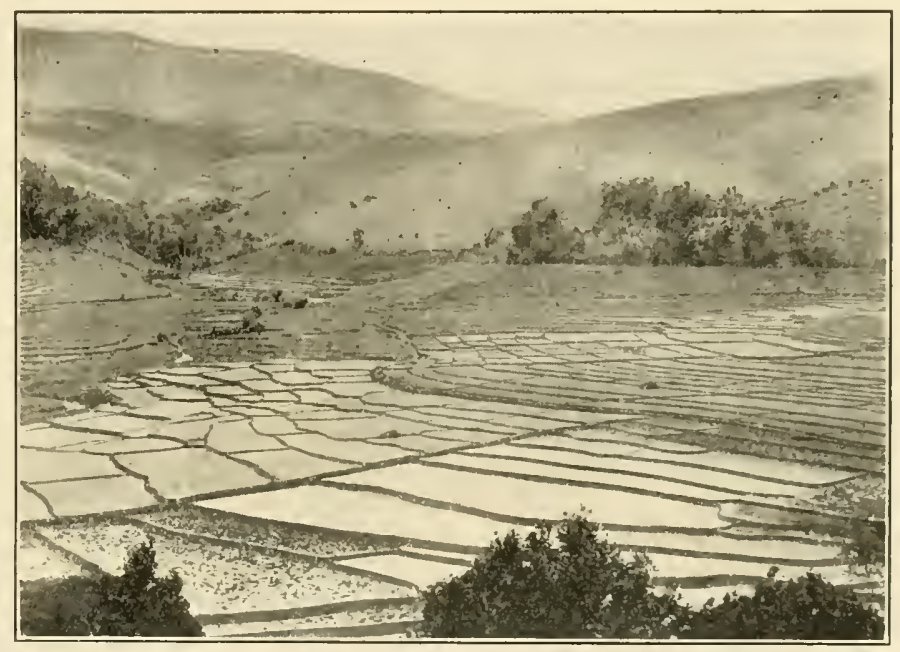

PADDY [RICE] FIELD IN CEYLON.

It may. perhaps, be well just here to refresh the reader's knowledge of Ceylon with the following facts. The island lies south of India proper, and is two hundred and serenty-one miles long and one hundred and thirty-seven miles broad, and contains about 24.700 square miles. It has under cultivation, or used for pasture. some 3.500 .000 acres-more than a fourth of its area. Of this about 520.000 acres are devoted to rice and other grains, the next largest planting being tea, of which there are about 400,000 acres. Other important products are cocoanuts, spices, coffee, sugar, cacao, tobacco, essential oil grasses, etc.

The population of the island is about $3,500,000$, of which less than I 0.000 are Europeans. The majority of the natives are Singalese, of 
whom there are over 2,000,000, the other races being Tamils (of whom there are nearly a million), Burghers, Eurasians, Moors, Malays, Vedahs (aborigines), and so on.

The island has an excellent government of the paternal sort, administered hy a governor who is appointed by the King of Engand. He is assisted by an executive council of five, but has power to overrule their advice. There is also a legislative council of nine, including members of the executive, together with eight unofficials appointed by the governor, representing the mercantile and planting interests and the native comnumities.

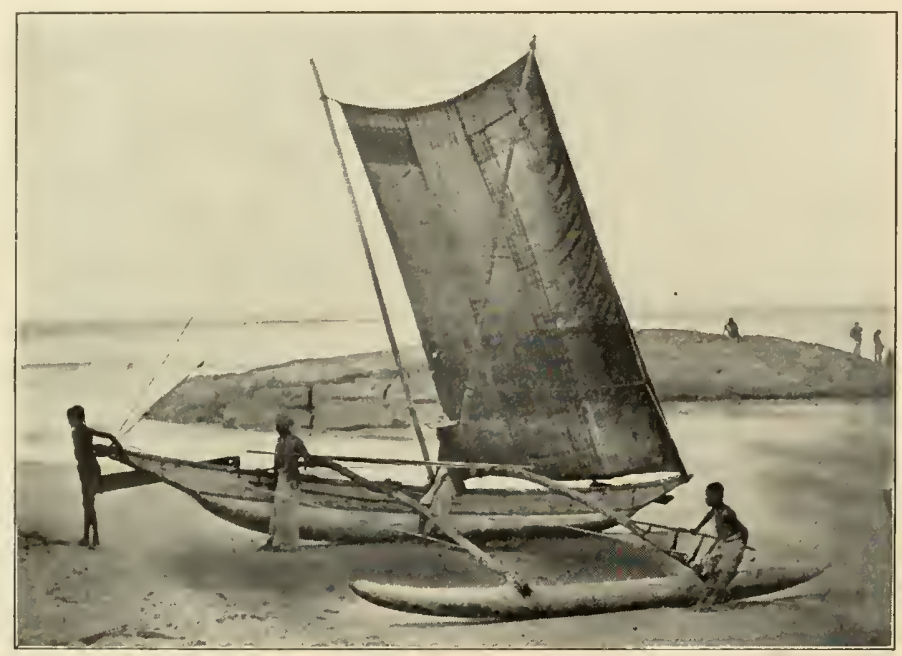

C.ITAMARAN WITH S.IL, CEYLON.

The island became a British possession in 1795. Prior to this the Dutch, who had held it for I 38 years, had wrested it from the Portuguese, who ruled it for If I years. Interesting reminlers of both of these conculests are found in the high-sounding Portuguese names that many of the Singalese bear, and in the Burgher types which remain quite Dutch, both in name and appearance. Neither the Dutch nor the Portuguese had ever conquered the whole of the island, which was acconplished by the British in 1815. Sinee then there have been a few rebellions, which, however, were easily suppressed. During the last one, in 1848 , some 2,000 up-country Singalese were put to flight by thirty Malays who wore the British uniforms, a proof that the ancient warlike spirit of the Kandyans is practically extinct. 
My first task after I was comfortably settled at the (ialle latee was to buy a sun luelmet, or toper, which l was lucky enough to fund in one of the native stores that ocenpy the gromud floor of the hotel. There are two dangers against which visitors to this part of the world must guard most carefully: one is exposure to the sum, and the otler a sucklen chill. In no part of the worle, if reports are true, is the sum so deadly ats lsere, but the danger may be reduced to a minimum if one will but listen to the advice of the older residents, and take reasonable precatitions. A pith sum helmet is indispensable, as straw or felt hats are sources of

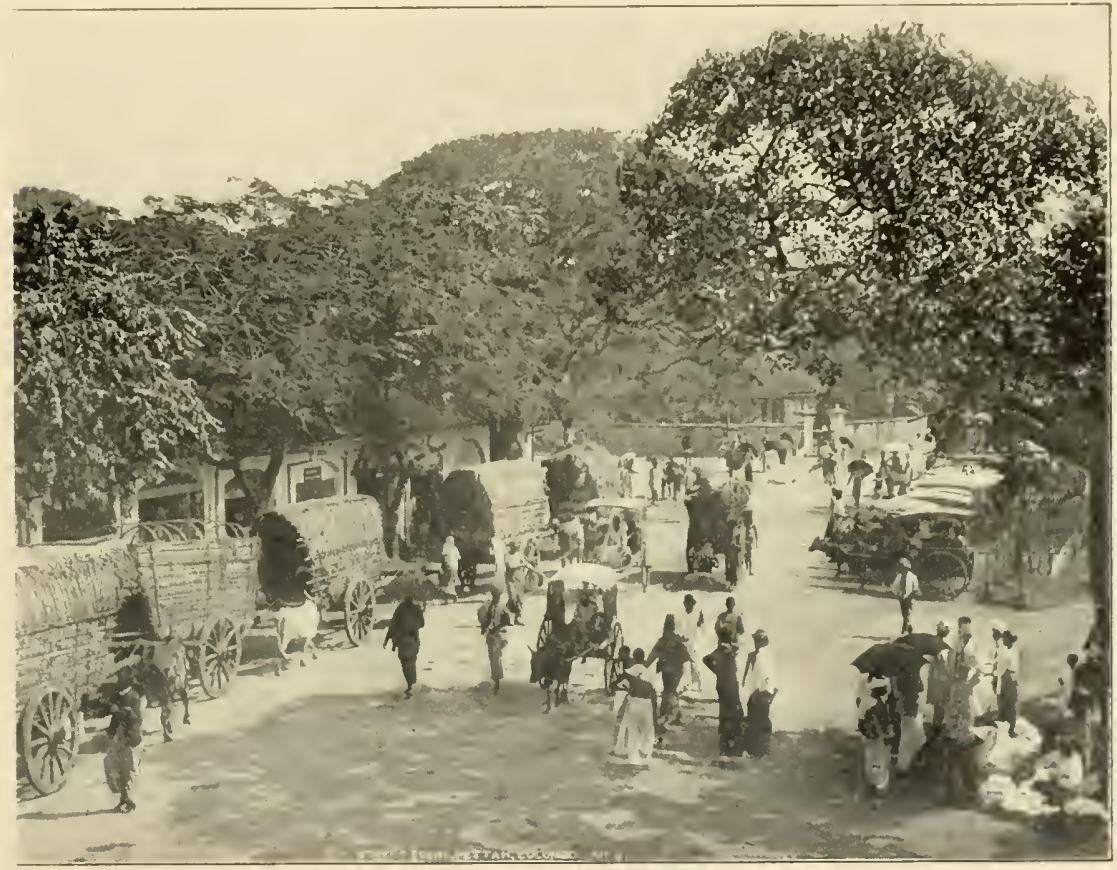

STREET SCENE IN COLOMBO.

langer, and a cap is worst of all. In addition, one slonld at first carry an umbrella as well. Nor is the danger present only at midlay, or when there are no clouds. It is practically as bad at seven in the morning. or when the sky is wholly covered with clonds. The habits of the dwellers here-that is, the Europeans. speak of this danger. Wen and women wear sun helmets and carry sum umbrellas, while broad rerandahs and close lattices guard the houses. Even the railway carriages have, in addition to curtains, visor-like projections to keep out the searching rays 
of Old Sol. There have been cases even of sunstroke through the eves, from the intense glare reflected from white roads or from the water, while a single shaft of sunlight, entering a crevice in a shutter, and falling on a man's temple, has been known to result fatally.

Where the heat is so great, it seems almost absurd to talk of chills, but when the sun goes down, and it still remains so hot that collars wilt, and the whole body is wet with perspiration, there comes that danger. The breath of the northeast monsoon, the regular wind of the winter months, while not cold, has brought on many a fatal chill, and resulted in fever and death. Hence most of the Europeans wear flannel bands about the abdomen (cholera belts they are called), and are very careful not to sleep in a draught, or to cool off too suddenly when very warm.

The natives, on the other hand, seem to be almost invulnerable both to the sun and to the "soon." They go about bareheaded, and almost bare-bodied, and sleep when and where they will, and rarely suffer from such exposure.

Equipped though I was to stand the heat, I was not proof against surprise, nor the delight that I felt when I saw standing in the hotel lobby, my good friend, Henry M. Rogers, of Boston, one of the directors of the Revere Rubber Co. He did not see me, and as my sun helnet would be a sort of disguise, I went up to him, and said:

"Do you wish a guide, sir?"

"No, I thank you," he responded politely.

"But you do!" I insisted, "You are lost now, and don't suspect it. I will not only guide you for nothing, but will be glad to pay for the. privilege."

I saw a glean of recognition come into his eyes, as he saicl: " $M_{y}$ dear boy. the rubber trade of the Lnited States sent me over here to watch over and guide you. It is you who are lost, and I am delighterl to find you."

Then we had a love feast, and instead of feeling far from home, kindred, and friends, it seemed as if the niles between Ceylon and the States were few, and most easily annihilated. At the same time, it dicl seem a bit unusual that we two, starting from the same city, and circling the globe in opposite directions, without any knowlerge of the other's alsence from home, should meet as we did. It was also very jolly: 
After proving to a score of Mohammerlan merchants who ham the hotel that I desired to buy no jewelry, silks, curius, or unset stones, and threatening the native tailor and shoemaker with my umbella, I hat a chance to look about. The hotel is heautifully situated on the seashore, its courtyard crowded with cocoanut palms, its broarl verandahs. latticed blinds, and ligh ceilings making it ats cool as one cotld expect in so torrid a clime. It was impossible for me to communicate with any of the planters that day, so I gave myself up to the pleasant task of watching the strange people that surrouncled me. For example, a Hinclu juggler, with the inevitable native flute, and a basket of cobras, invited

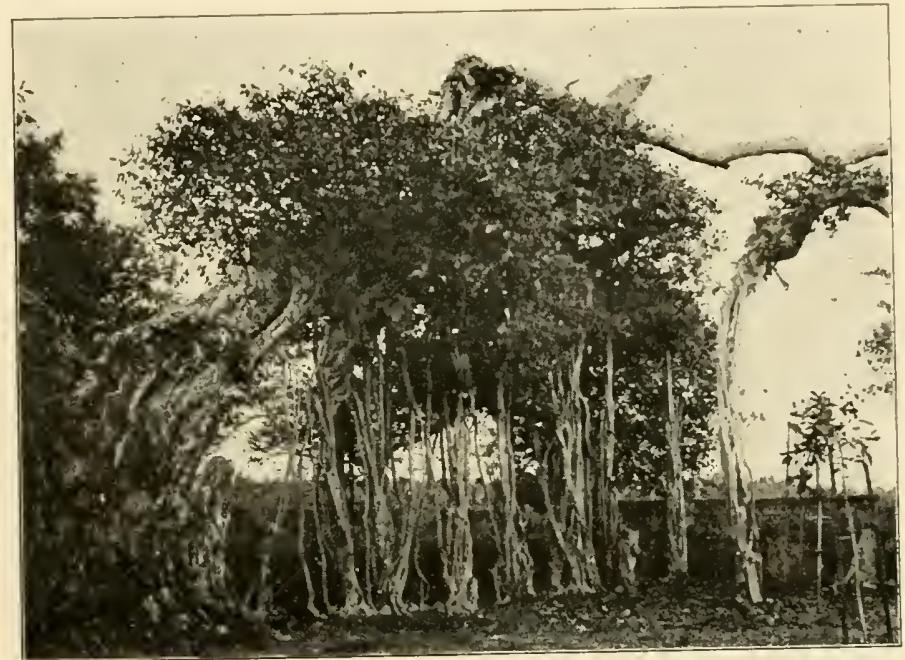

BANYAN TREE, CEYLON.

me out upon the lawn to view his magic. I thought it worth a rupee to see the "mango trick," and I was not able to detect any fraud in the sleight-of-hand by which he apparently planted the seed, made it sprout. and within two or three minutes grew a pretty shrub more than two feet high. By encouraging a rival of his, I also saw a lively little mongoose attack and kill a huge ratsnake, but no inducement was effective in getting him to trust his cobra within reach of its traditional enemy.

Just as the exhibition ended, along came a steamer friend, with the information that he had engaged a gharry to take us out to Mount Lavinia, a favorite shore house some three miles away. As it promised to give me a view of the country. I gladly consented, and we were soon bowling along over the fine roads, drawn ly a very diminutive but 
energetic pony. On the way. we stopped at a Buddhist temple, and, under the guidance of a priest who spoke excellent English, we saw the great inage of Puddha, in the forehead of which is set a sapphire as big as a teacup, which glows and sparkles with a most uncanny luster when the room is clarkened.

IVe also saw the small temple, where, securely sealed forever from humman sight, are the sacred books engraved on plates of gold and silver. The doors to this little building, by the way. were walled up some eleven hundred years ago. As a special favor, the priest showed us a footprint of the god in solid rock. To my mind, it dicln't do Bud justice, as the pedal extrenity was exceedingly flat, and the toes looked

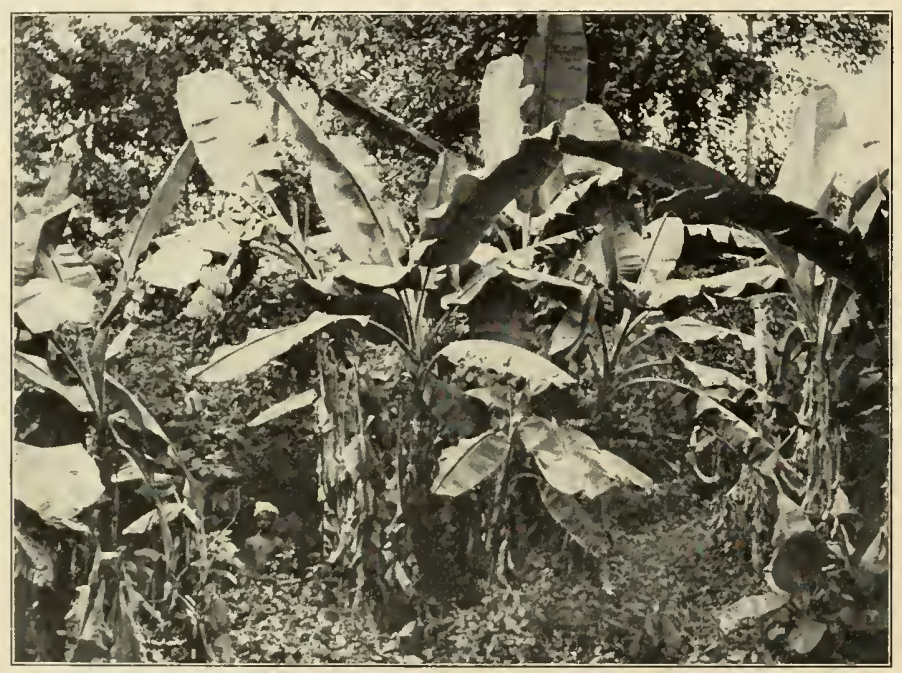

I'L.INTAINS, CEYLON.

as if they might have been whittled out of soft pine by a very poor whittler. The size of the foot, however, was all that could be desired ly any heliever.

He also sbowed us a series of striking pictures, illustrating the various types of torture in the hereafter for those who killed any living thing here on earth, even to the insects that make the finc-toothed comb a necessity. I was surprised to find among them special tortures for those who fish and hunt.

In the temple enclosure we were at peace, but once outside a half lundred legerars, hig and little. crowded about us, following closely down the narrow lane towards ont carriage. I was afraid some of 
them would give me of their various skin diseases, so I hired the priest for a rupee to keep them all at a distance, until we were on our way out. which he dirl.

The drive to Mount Lavinia was so full of novel scenes that it is almost impossible to select even a few that are typical. Throngh the narrow streets, croweded with native houses, from which swarmed halfclad men and women, and nude children. meeting Tamils, Singalese, Chinese, Moors-indeed all types of black and yellow men, turning out for carriages of all sorts, jinrikishas, bullock hackeries and huge two-

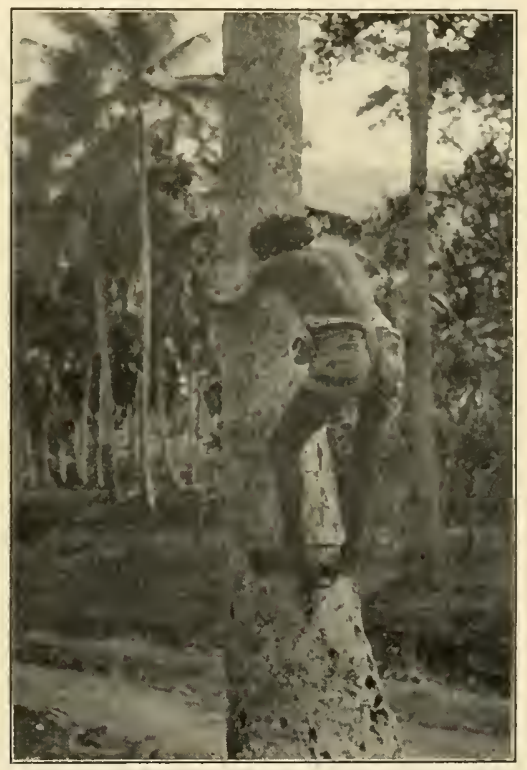

NATIVE METHOD UF TREE CLIMBING.

wheeled thatched-roof wains, getting a glimpse of a rare tropical garden, then of a squalid Tamil hut, by Chinese graveyards, European villas. cocoanut plantations, banana patches-all over a road of good hard "chabok." we went, until we drew up at the little hotel-crowned height of Mount Lavinia. Here we had tiffin, with coffee, out on the lawn under an umbrella-like tent. where we lay in reclining chairs and watched the sapphire sea studded with native fishing boats, their huge brown sails swelling with the breath of the northeast monsoon. It was scorching hot in the sum, so we waited until late in the afternoon, and drove slowly hack to the hotel. 
I was awakened early next moming by my black Tamil bedroom man, who brought coffee and bread and fruit, and informed me that "Master"s" bath was ready. Is I pulled the mosquito curtains aside, and got slowly ont of bed, I was startled by a flapping of wings, and a very black and impudent crow alighted on the window-sill, his eye on the tray of fool, and waited impatiently for me to go to the batliroom. On the tiled roof opposite were half a hundred more, awaiting the

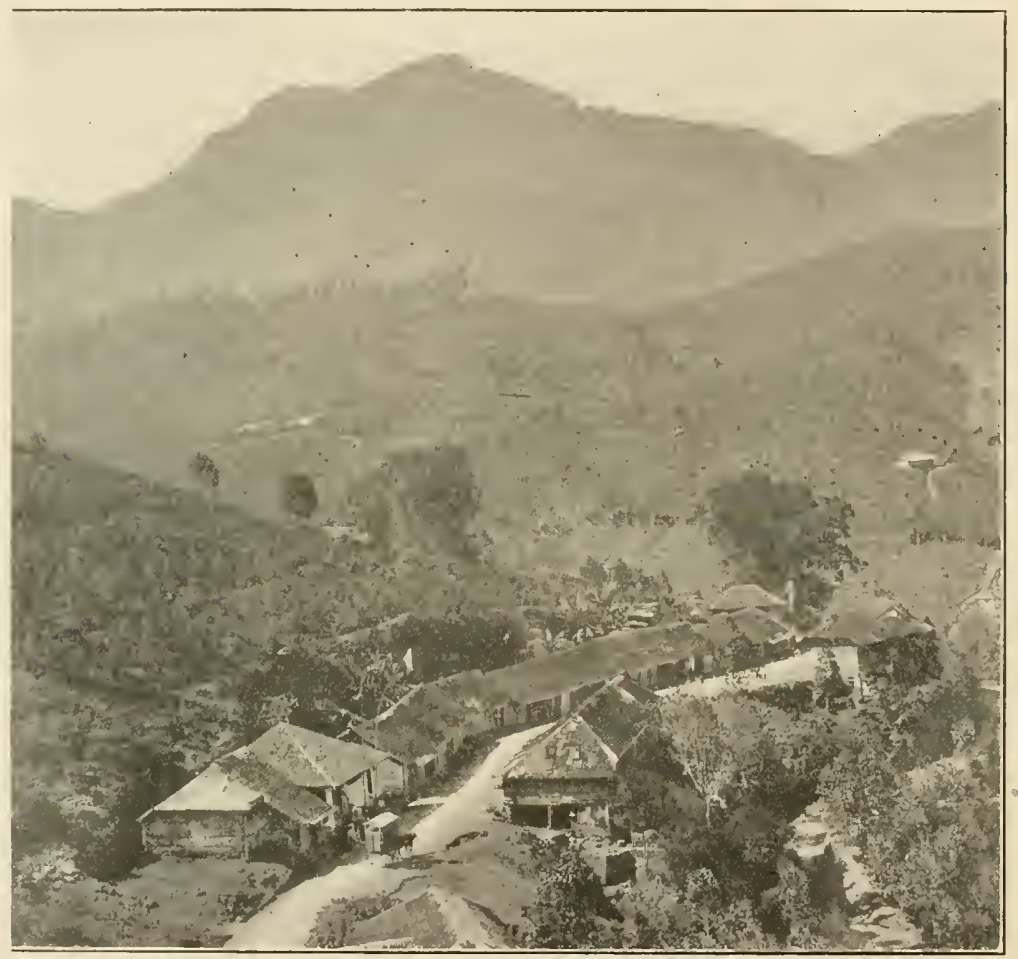

AN LPCOLNTRY TE.I ESTATE IN CEYLON,

[Great Western Mountains in the bacliground.]

results of his investigation, so I took my coffec then and there. On my return, not a crumb of food remained, much to the disgust of a couple of sparrows who were investigating my belongings with all sorts of profane comments. They left, however, when the lizard began to sing, and I clich't blame them, for however common and useful the houselizard is in Ceylon, and even if it can catch more flies and mosquitoes than anything else, its song is not real music, and if you try to stop it, lyy throwing a bout, the tail drops off, greatly injuring its looks. 
Very early in the day. I was introluced by my requen to the dhoby man. Who is the watherwoman of the East. He takes one clothing ont to the nearest stream, wades into the water, ancl pounds the dirt ont on the rocks, then partially dries and irons them. He also has a halut of infesting them with a parasite which results in the "llholies" itch." । hat a misture of starch, beric acid, and pewerered zinc, which I desired to try on this parasite, and althongh I told him when le took the contract to be sure to give me my money"s worth of germs, I lisint get one, and I am sure he had some, for he was always scrateling. I fancy he delivered mine to the chap who hat the rom neyt to me, for 1 used to hear him scratching and "saying things" when night harl fallen, and the "spicy. breczes blew wh wer cerlon's is.e."

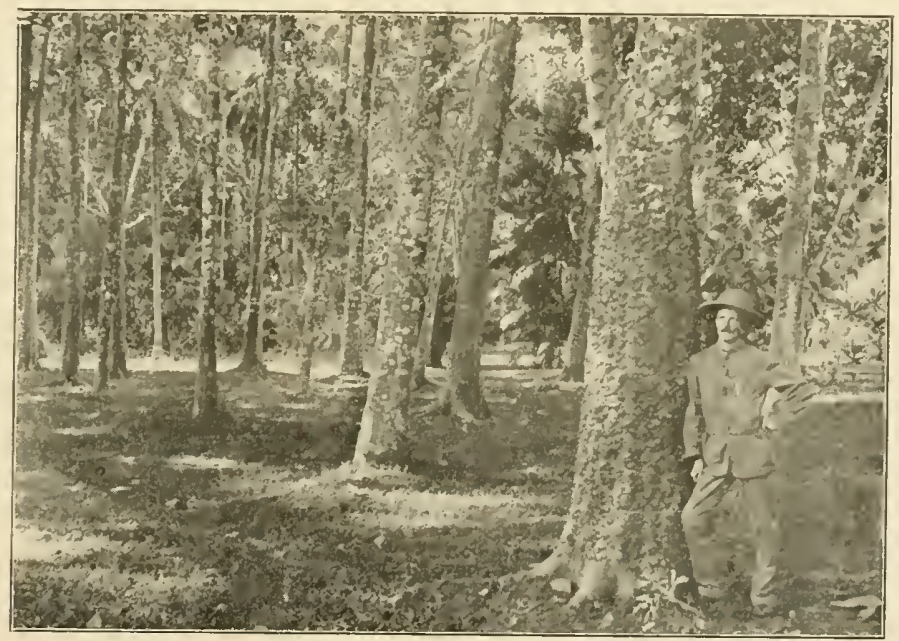

"HEVEA" AT HENERATGODA.

[Large tree in foreground on which tapping experiments were made for several years.]

The next monning I called on Mr. Ferguson, of the Tropical Agriculturist, who for many years has been a high authority on tropical planting. To my regret, he was absent, heing then in the Cuited States, and. his nephew informed me. likely to call at my New York office at any time. I learned, however, that Director J. C. Millis, F. L. S., of the Royal Botanical (ardens. Peradeniya, was then in town, and at the hotel familiarly known as the "G. (). H.," meaning the Grand Oriental Hotel, where I found him, and was able to secure his assistance in planning nuy visit to the typical Heren plantations. 
Prior to my visits to the plantations, in talking to those who were supposed to know about rubber plantations, there was a great unanimity of opinion as to the profits shown. One man, not an optimist either, said that in two cases he knew of, the first year's tapping had paid for the whole of the the original investment, and that the second year's production had shown a profit of 120 per cent. He was not quite sure

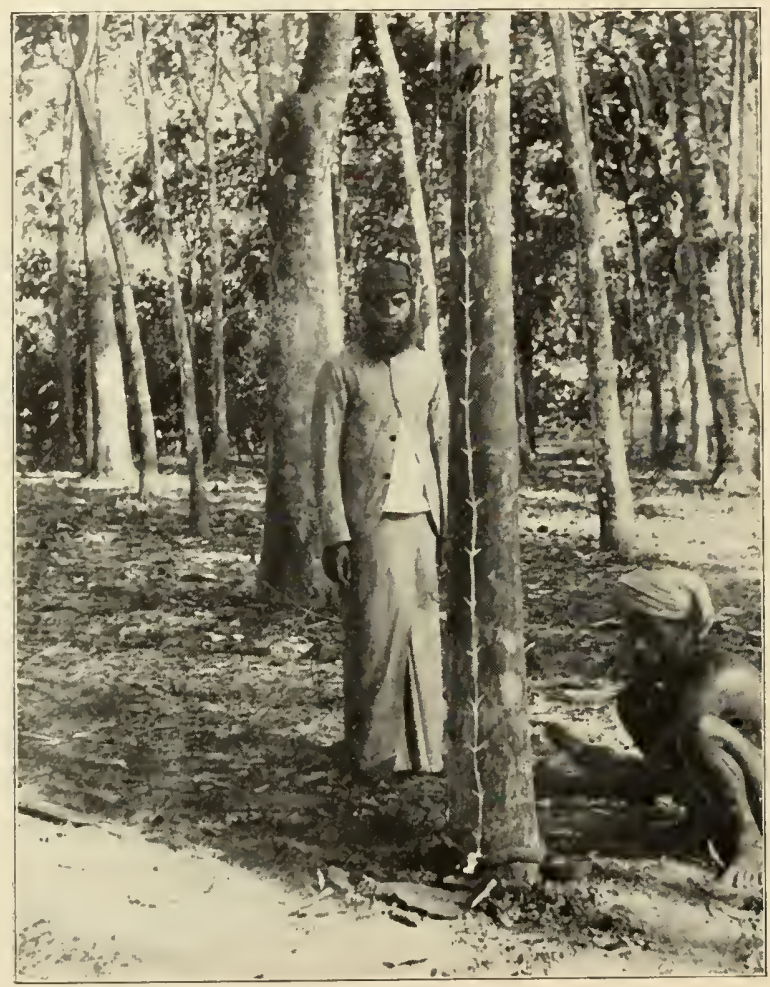

PARA RLHHFR TREFA ( HEYE.A BRASIIIENSIS) AT HENERATGODA.

[Tapping with Mallet and Chisel.]

of the age of the trees when first tapperl, but said they were certainly not ten years old.

He said that when the planters had in view any new product that looked pretty good, the natives always planted a little of it, so that when harvest time came, they could secure a little from their own plantation. which, arled to what they were able to steal from the white planters, often marle a very good showing. Thus they were alrearly planting the Heace in a small way, and wou'd douthtless later do more or less night 
tapping on the plantations of the white men. () f conrse, once they have the rubler, it is impossible to prove title to it.

In chatting with Director Willis, it was easy to see that he was enormonsly interested in the success of the Herea experiments in Ceylon, and, incleed, in the whole of the East, and that he was doing much to further them. That the whole of the tropical world in the East was fully alive to the opportmity that rubber offers, he acknowledged. The botanic gardens at Peradeniya, and the plantations as well, are constantly receiving visitors from Java. Sumatra, French lndo-China, Siam, and sinilar conntries, who are investigating the subject, and often trying to contract for seed on the spot.

As the oldest planting of Herea rubber in the island is at Heneratgoda gardens, which is one of the government gardens, under the direct charge of Mr. Willis, he thonght that my plan to go there first was a yood one, and at once gave me a letter to the contractor in charge, Mr. William Perira.

()n the following morning, therefore, I had coffee at $4 \cdot 30$, and took a "rickshaw" to the railway station, and ere long was speeding along the seacoast toward my destination. The rising sun disclosed long stretches of swamp and jungle, stretches of sandy shore crowded with cocoanut palms, native villages just awakening. fishing villages where the whole population was engaged in pulling nets that had been filling up all night. and in time we reached the railway station at Heneratgoda. Iere as I could get neither gharri nor rickshaw, I was obliged to cliarter a bullock "hackery." 


\section{SECUND LETTER.}

Growtil of Helea Trees at Heneratgoda-Their Yield at Virioes AgesVisit to Peradenixa-Director Willis and His Work-Canker Fungus in Hevea and tts Treatuent by Mr. Carrethers-Rillways in Ceylox-Plantation Scenes-Leeches axp Other Insect Pests.

A BLLLOCK hackery is a small two-wheeled cart, gatudily painted, 11 with oikchth top, no springs, and a seat on which sits the ciriver. so close to the little humb-backed bullock that he easily twists his tail, or punches his ribs to make him trot, while the passenger, sitting back to the driver, clings as best he may. It is a most jerky mode of

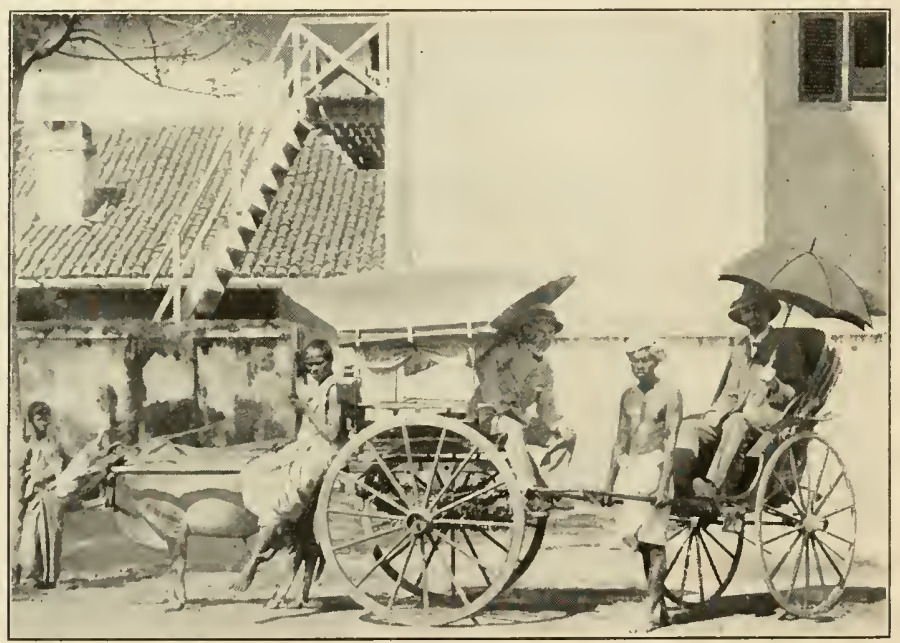

BULIOCK HACKERY AND RICKSHAI, COLONBO.

progression, as the bullock starts and stops with surprising suddemess; indeed, his whole progress is a series of jerks against which it is difficult to guard. Were it not for the little step behind on which one's feet rest, it would he impossible to hold on for more than five or six minutes. The bullock is a tough little beast, about four feet high at the shoulders, and is supposedly guided by a pair of rope reins that run through his nostrils. He is, however, more influenced by the half bark, half rell, of the driver, and the vigorous tail-twisting that he indulges in on occasion. 
From the statum I rode thromgh a most densely poptulaterl native village, with narrow streets and a smell of stale fish that was simply appalling. Here we gathered a lot of flies, but as they ultinately settled on the bullock's bump, no especial annogance cance from their presence. Finally we reached the entrance to the gardens, turned in, and in due time found Mr. Perira, who at once put himself at my disposal. (In the way he showed me some Ceará rubber trees which appeared to have grown well, but as that tree in Ceylom has not prover profitable, it was

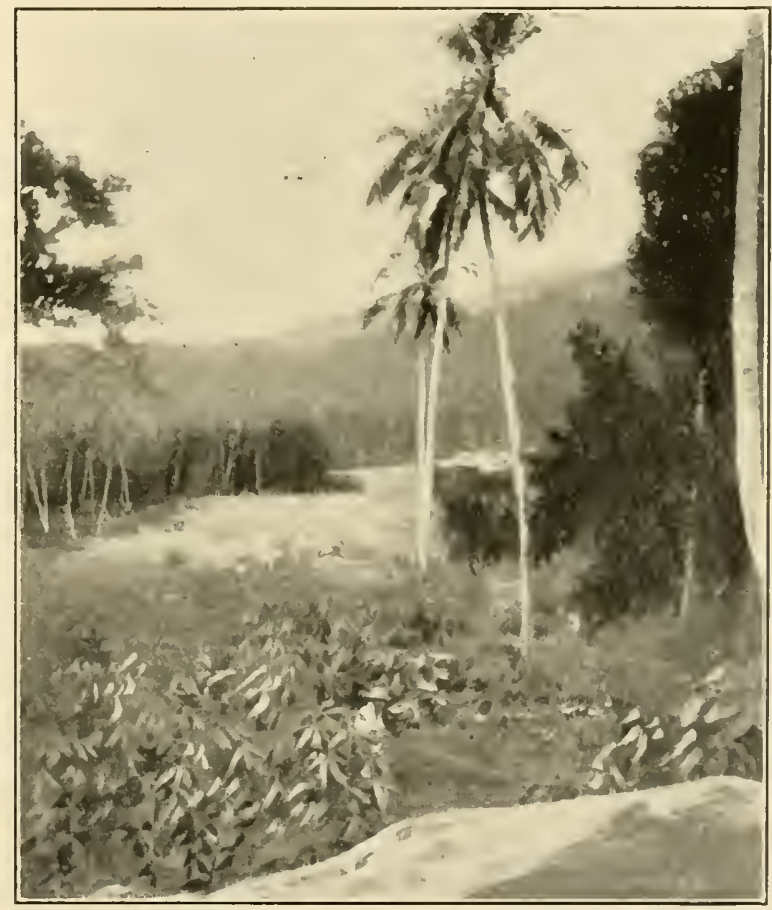

EXPERIMENT GARDEN, PERADENIYA

[Ceará rubber in foreground.]

to me of only transient interest. I did, however, measure one, twenty years old, which was two feet in diameter three feet from the gromd, and was probably fifty feet high. That it contained some later I proved by cutting into it.

A short distance away, on a somewhat lower level, was a grove of Heicas twenty years old, sixty to serenty- feet high. They were planted about ten feet apart, and had taken full possession of the soil, no weeds 
or grass growing in the dense shade they cast. The trees looked very healthy, with smooth bark and straight limbs, the branches appearing about thirty feet from the ground. There were about three hundred trees in this lot. They have been tapped experimentally a few times, but they are kept as seed bearers rather than rubber producers. The soil

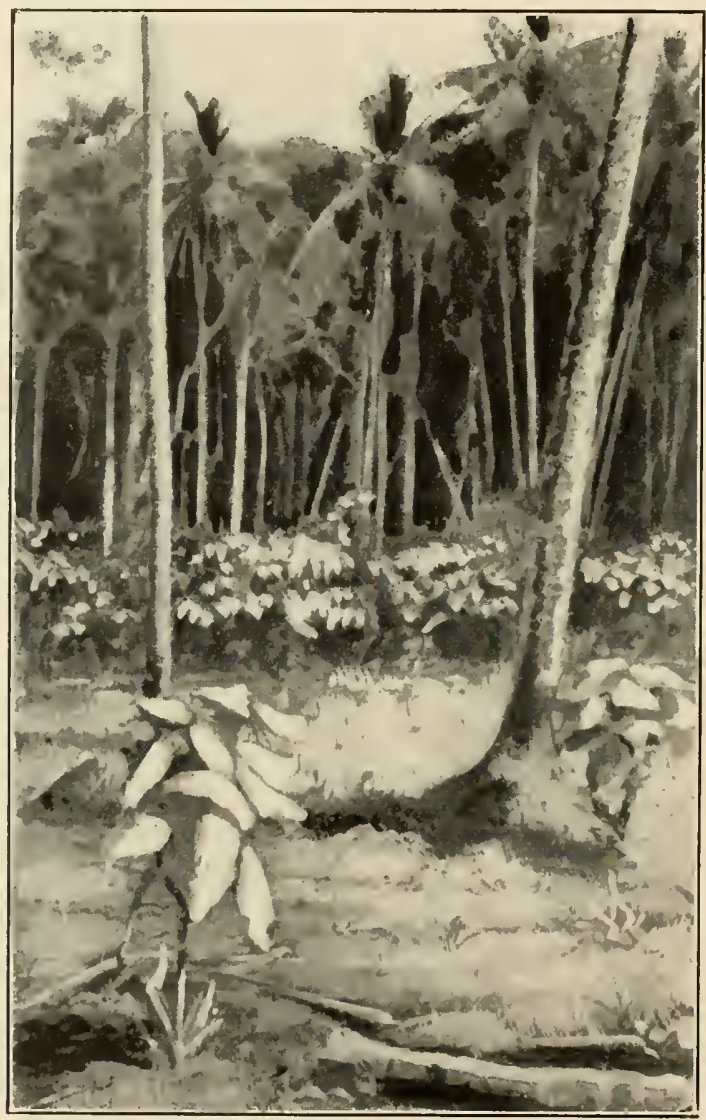

I'ERADENIYA GARDEN.

[Castilloa clastica planted among cocoanut palms.]

is gravelly, but seems to grow almost anything. The land is but thirtythree fect above the sea level, and the annual rainfall less than one huncired inches.

Not far from here is the oldest planting of Heiea at this place. These are trees about thirty years old. They are fine specimens, with massive trunks three or more feet in diameter. As a rule the trunks 
are straight, single stems, but here several of the larger ones have dividerl trumks. I had a look at a few specimens of the Castilloa clastica, but they did not appear to be floing well. I was also interested to see a sood specimen of the Landolphia florida, which dicl not strike me as a vine that it would be at all profitalle to cultivate.

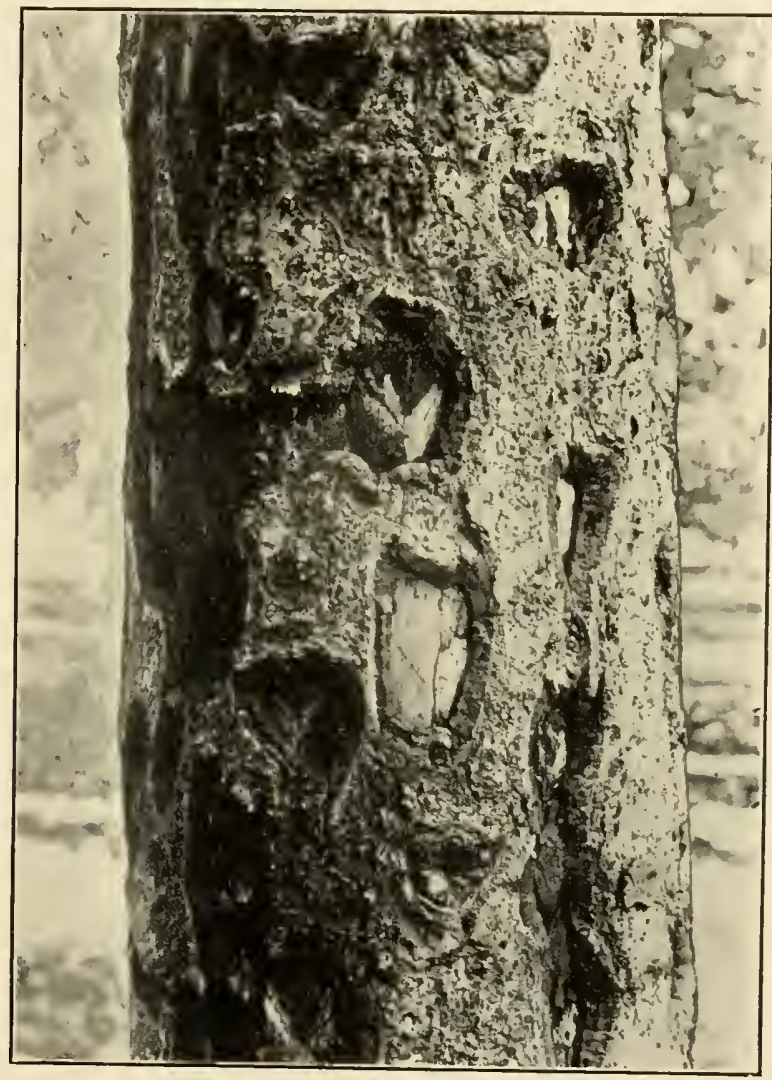

PORTION OF OLD "HEVEA" TREE.

[Showing proper healing of wounds that do not pass through the cambium, and injury caused by those that go too deep. Wounds made by chisel and mallet.

Heneratgoda Garden: tree I3 years old.]

It is here at Heneratgoda gardens that the first successful planting of P'ara rubber occurred, and what is more important, it is due to the eminent scientists in charge of this garden and that at Peradeniya that we have any sort of knowledge of the growth and productiveness of the Heica tree under cultivation. Their work dates back to 1876 under 
Director Thwaites, when 70.000 seeds, sent from the Amazon to Kew gardens. London, were set out, only four per cent. of them germinating. From there about two thousand plants were sent in wardian cases to Ceylon in charge of an experienced man, Mr. W. Chapman, and ninety per cent. reached the gardens in an excellent condition. These were set out in bambor pots and the next season were transferred from Peradeniya to Heneratgoda and flourished almost from the beginning, but the planters had set their hearts on the Ceará tree and paid little atten-

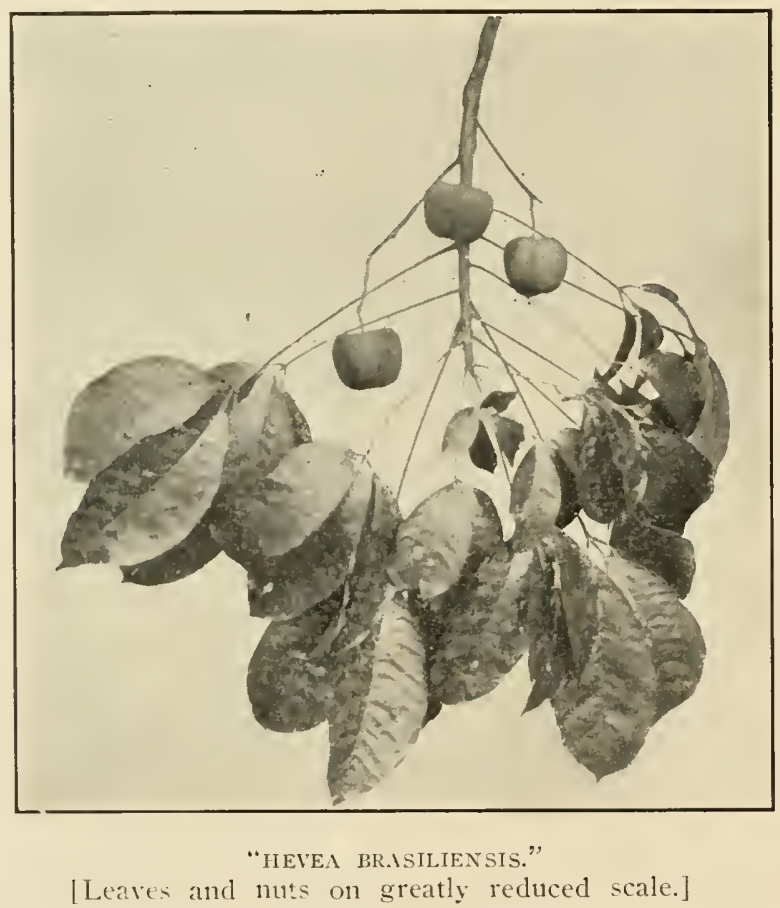

tion to the reports that the Director of the Gardens. Dr. Trimen, Dr. Thwaites" successor, made from time to time as to their growth.

In 1883 several of the Hered trees at Heneratgoda flowered, and from the ripened seeds two hundred and sixty plants were raised and distributed to various planters. One year later, one thousand plants were raised in the same way and sent out.

In 1886, the Pará plantation at Heneratgoda was thinned out, all of the smaller trees being cut down, after which there was a noticeable improvenent in the growth of the remainder. Seeds were sent that 
year to Janaica, Madras, Rangoon, I'enang. and the botanic garilens at linitenzorg. Java, while from the crop of 1888 there were sent w the Straits Settlements some 11,500, together with 1.000 to the Fiji Islands.

Dr. Trimen made annual neasurements of a typical tree at Heneratgoda, which are as follows, the tree being planted in 18-6. The measurements are circumferential, and taken, as is the custom, three fect from the ground:

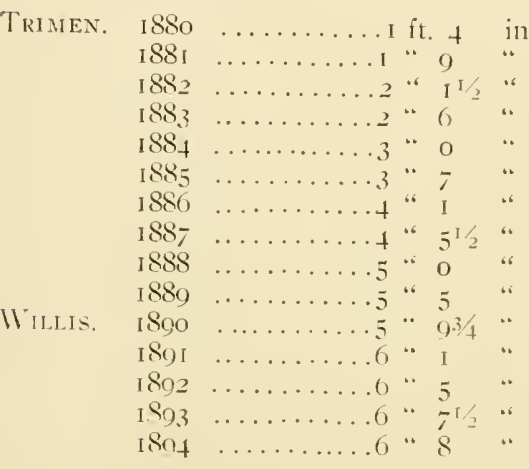

The first of the above measurements was taken by Director Trimen, and the latter by Director Willin. his successor, who sars rery justly. that more useful data is secured by measurements that give the mean girth of all the trees. He therefore measured in 1897. forty-five trees that stand about thirty feet apart. that were then twenty-two years old. The measurement was taken at about $5 \frac{1}{2}$ feet from the groumd. The largest tree was 7 feet 5 inches. the smallest 2 feet I inch, the mean girth being $4_{+}^{3}$ feet.

In this connection it is interesting to note the meastrements of wild Hecea trees made by Robert Cross in 18 $7 \%$. near Pará. These trees had been tapped for from five to fifteen years, and their age was No. I urknown. The figures are given hereNo. $2 \ldots \ldots \ldots \ldots, 6$ " 10 " with.

No. 3 ............. + " 7 "

No. 4 , . . . . . . . " 0 "

No. 5 , . . . . . . 5 " 10 "

No. $6 \ldots \ldots \ldots \ldots, 5$ " 3 "

No. $7 \ldots \ldots \ldots \ldots+\cdots+{ }^{2}$.

Niv. 8 ............ 5 "

No. $9 \ldots \ldots \ldots \ldots \ldots+$.

No. Iо ........... + 6 " 6

No. I1 , ......... + 8 "

No. 12 .......... 2 " 8 "

Mean N........... + " 10 "

All of these measurements were taken at three feet from the ground. It would scem, therefore, that the trees at Heneratgorla had about reached their growth.

It is as a seed-bearing proposition that the garden I was risiting appealed to me most. I hasty bit of figuring gave me the total of between 3.000,000 and $4.000,000$ Para seeds that had been sent out to planters all over the Eastern tropical world. A wonclerfully practical piece of work and one for which the tropical planter should be devoutly thankful. 
One of the few tapping experiments extending over a series of years was carried out at Heneratgoda moder the late Dr. Trimen. He selected a twelve-year-old tree that was $50 \frac{1}{2}$ inches in girth, three feet from the ground. This was tapped the first. third, fifth, seventh, and ninth years, the product being thirteen pounds seven ounces of dry rubber. As in any of the tapping years but seventeen tappings were caken, and they were well distributed through the twelve montls, it would seem as if the tree might just as well have been producing every year instead of every other year, and that its average of one and onehalf pounds a year inight just as well have been three pounds.

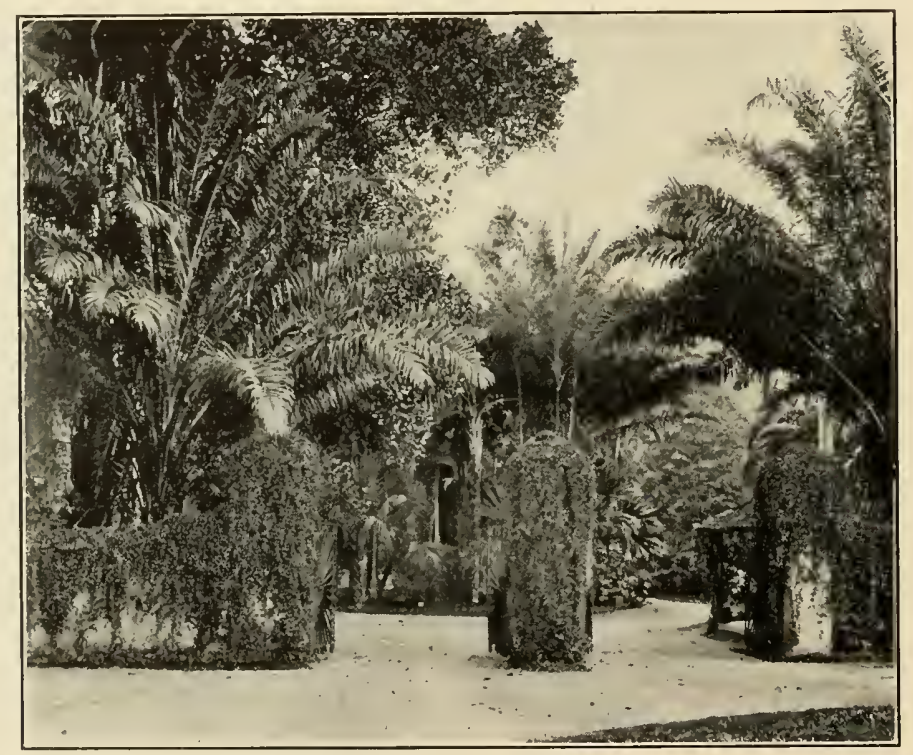

I ERIJENIYA GARUEN ENTRANCE.

These experinnents were followed by others by Director Willis, in which from smaller trees he secured on an average about one-half pound a tree, but where the trees were planted much more closely together. A curious fact in connection with the two experinents is that, supposing the Trimen trees had been tapped yearly and produced three pounds each, and the $1 \mathrm{~V}$ illis trees produced one-half pound each, the result would mean the same production per acre, as the former stood fifty to the acre, while the latter were three hundred, in either case the production reaching one hundred fifty pounds per acre. 
These yelels, by the way, are not large, as Heneratgorla is not to be compared with other parts of Ceylon as a rubber prorlucing locality. The many other and valuable experiments that were carried out here and at Peradeniya would fill volumes. Exhaustive experiments were made, for example, as to the kind of incision that gave the best results, whether the "herring bone," the $X$, the $Y$, or the single / was the best with records carefully kept and compared to learl to the right conclusion.

Then, too, experiments by the score were made to find what part of the tree was the hest to tap, whether near the base or high up on the trunk. In addition to this, a long series of experiments in the coagu-

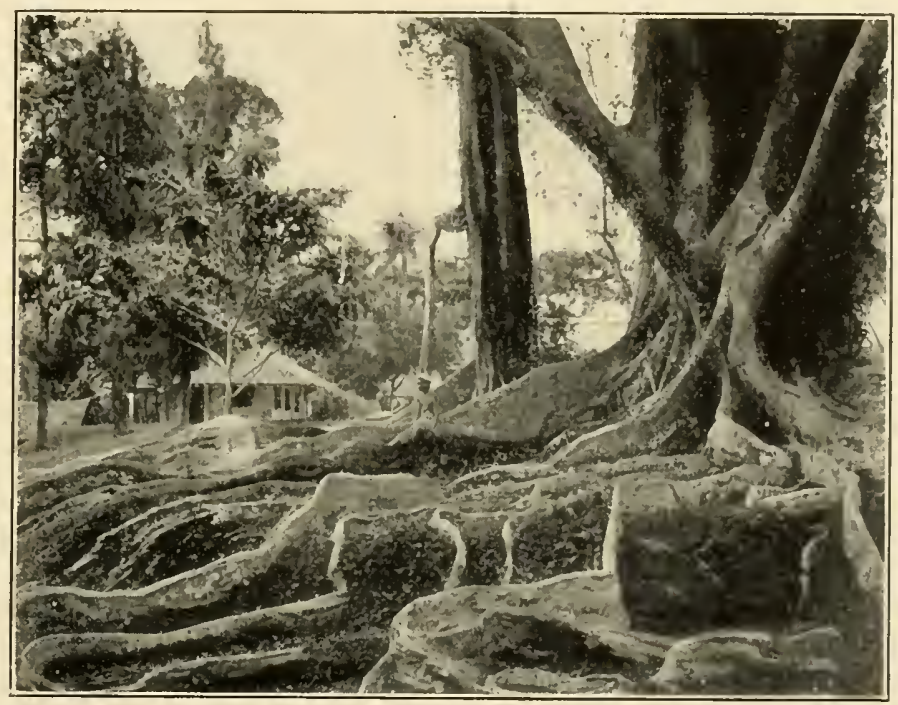

"FICL'S ELASTICA." PERADENIYA G.ARDEN.

[Showing spreading buttressed roots.]

lation of the late. were instituted both by centrifugal machinery and $b y$ the employment of a variety of acids. It is due directly to this investigation that the Ceylon planter to-day, if he wishes to hasten the coagulation, adds a few drops of acetic acid to the latex. Nor were these experiments done $i_{11}$ secret. The results were published and scattered broadcast among planters all through the tropical world, with wonderfut results for good.

After a lasty look at the magnificent palms, of which the garclen has more than fifty varieties, the banana, pepper, and other plants. I resumed my hackery, and jolted back to the railway. As the return 
train was not due for half an hour, I went to the "Rest House," a hotel ownerl by the guvernment and run by a trusty native, where I had an excellent hreakfast. I paid the fixed charges, signed my name to the risitors book, saying that I was well pleased, and walking on to the station, canght the train back to Colombo. In the afternoon I hired a jinrikisha, and rode around the town. These "rickshaws" are simply huge perambulators drawn by a half naked coolie who trots along all (lay content with ten cents an hour (gold). Most of the rickshaws are (s)l and rattley, but a few lately introduced have pnemmatic tires, and it is only a question of time before they will all have them.

As Director Willis had been good enough to invite me to make my home with him when I went up comntry to visit the Peradeniya gardens, and as I had only one suit of white flannels, I got the tailor at the fialle Face to make me annther. I was measured in the moming and the suit iras delivered that evening. It cost ten rupees [=about $\left.\$ 3.6_{4}\right]$ for the making, and the man who delivered it got two rupees, becanse the tailor, his master, was such a hard man to work for, and the hoy who was with the man who delivered it got one rupee because of some affliction that he had suffered, and the dog that accompanied the boy who was with the man-well, he didn't get anything, lont I vow he sat up and begeed just as long as I was in sight.

I mack an early start for Peradeniya, which means "guava plain," soing by the government railway in a very comfortable first-class car that is a sort of compromise between the American smoking car and the English compartment car, and about half the size. The gorermment railways, by the way, are pretty generally gool in Ceylon. The equipment is all that could be expected, although the cars are small; the freight cars, for example, heing twelve-ton affairs with corrugated iron roofs, and the locomotives look very light. The railway stations, however, are extremely good, and in most of them a white man need not wait at the ticket winlow, but may march into the agent's sanctum, and set his ticket before the natives are served. The profits that the railroads carn is expenderl on the carriage roads, a plan that some praise and some condenn. Anyhow, the latter roarls are first-class, and an automobilist could go from one end of the island to the other if the elephants did not oloject.

Soon we were bidden to the "refreshment carriage" where a good breakfast was served for about sixty cents, after which I sat on the sharly sirle in my car, and tonk note of the great padrly fields in which sullen water buffalo wallowed and fed, and where natives, clad only in breech- 
cloths and daubed from hearl to font in clayey murl, toiled in a half hearted way. Then the scenery became more interesting as we climbed to higher ground, the road ruming above a winding valles where great stretches of jungle were broken ly lanana and rice pantations, with

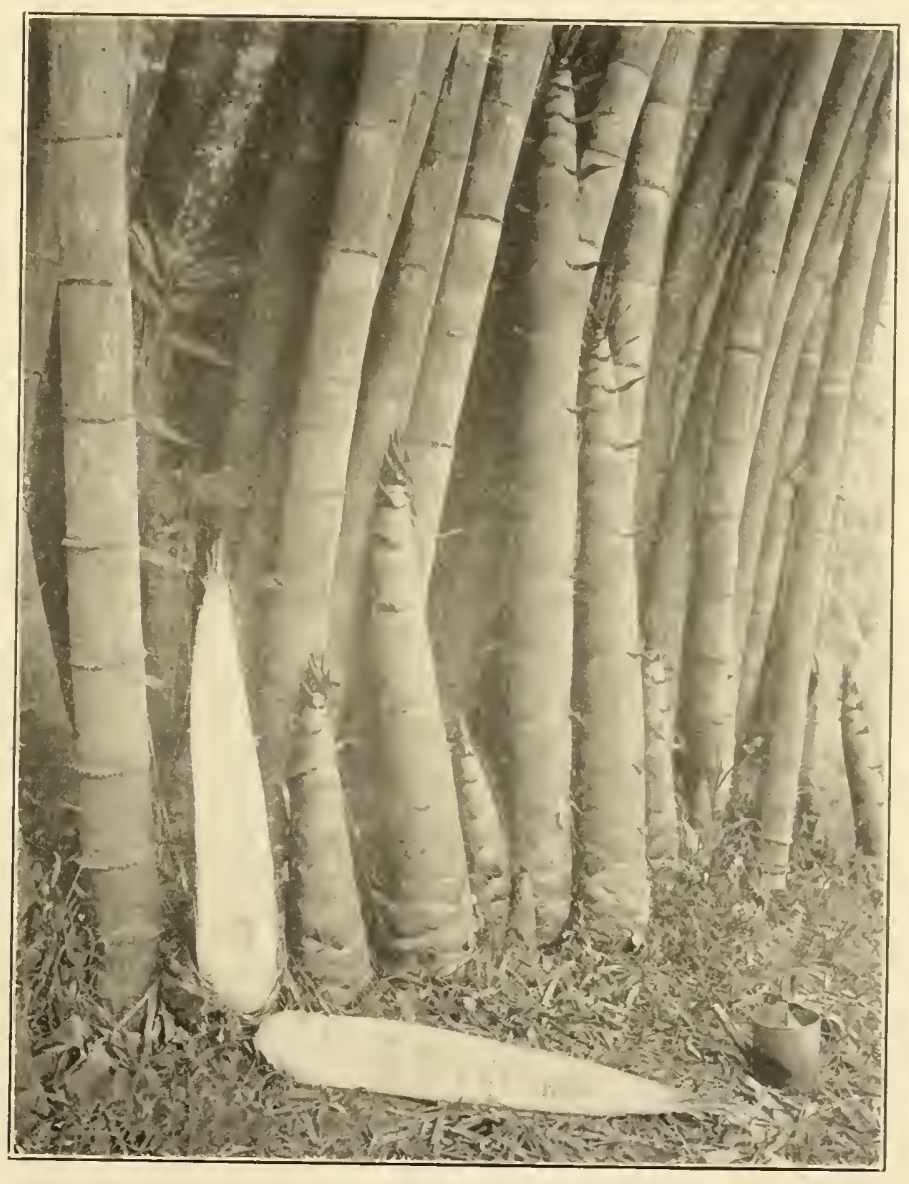

"DENDROCALAMUS GIGANTEUS."

[Giant bamboos in the Perademya Gardess, showing the young shoots, and a section of one.]

occasional glimpses of splendid govermment carriage roads, while rugged mountain ranges in the distance made an effective background.

Every now and then we stopped at a neat railway station, crowded with natives, interspersed with a few Europeans, for whom, by the way. the first-class waiting rooms and cars are always reserved. Between 
Polgahawela and Rambukkana, by the sicke of the track, is a very considerable plantation of Herea, covering some sixty acres, the trees being: planted about eight feet apart. They are about three years old, and would average, for a guess, thirty feet in height.

Further on, as we still ascended, the valley below was often a series of terraced paddy plots for miles. Then as we still skirted the valley,

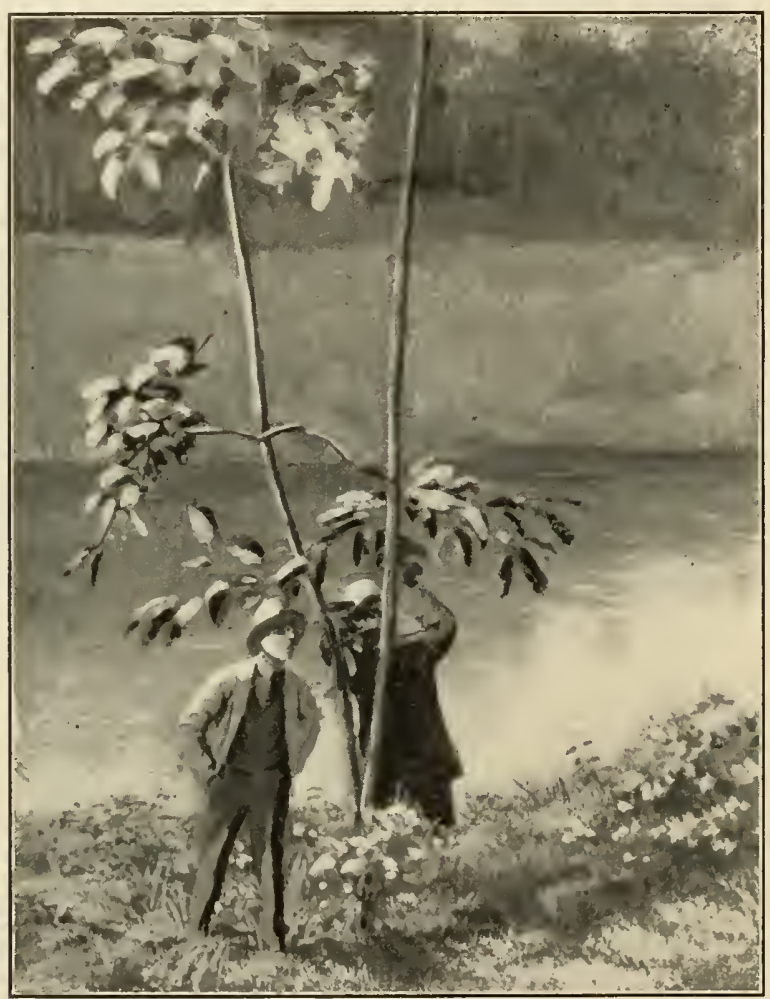

PER IDENIYA GARDEN.

[.Mr. Carruthers inoculating a young Hecou with Canker.]

which was farther and farther below us, we crept through many tumnels, clung to the sicles of precipices, getting occasional glinupses of Adam's Peak, the famous mountain of the island, and still far below, we saw winding through the jungle-crossing rivers-the white roads, hard, smooth, wicle, equal to any park roads at home. and then up, up, we climbed, the cablbage palms, bread fruit trees, and tropical growths now findling their hone on the rocks, or in the wash of steep mountain ravines. 
The ald wat raphlly growing drier, a decieled relief after the steamy atmosphere at the sea level: nor dicl I note the heat ats I leaned out to see as much as possille of the great tea plantations that now filled the valleys, and encroatched often on the steep hill and menntain sides. The soil, where it was in evidence, hat a redelish look, and would not sugerest fertility were it not for the luxuriant growth it preduced.

After a journey, full of intense interest, we reacherl l'eradeniya station, and, alighting from the train, I found Director IVillis awaiting me. One of his coolies took my luggage in charge, while his master and I walked up the broad, sharked roas that runs by the beatutiful entrance

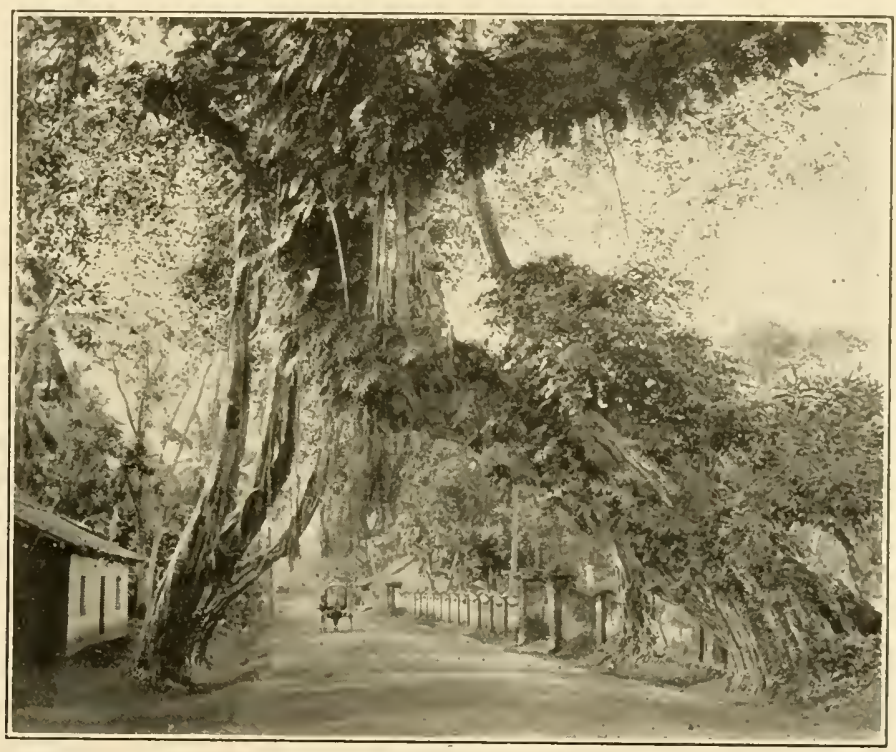

"FICUS BENGALENSIS"-BANYAN TREE [In the main street at Kalatura.]

to the Royal Botanic Gardens. A few minutes brought us to the IVillis bungalow, a very pretty two-story house, set on a little eminence, and hemmed in with foliage plants, flowers, and magnificent shade trees. As the new governor of Ceylon, Sir Henry Blake, had requested the presence of my host in Colombo, he turned me over for the moment to Mr. J. B. Carruthers, F. L. S., the mycologist and assistant director. Mr. Carruthers, by the way, had but just returned from a montlis visit to varions Howa plantations, where he had been studying the canker that had appeared npon some of the Herea trees. He was of the opinion that 
the alertness of the planters in discovering the disease in its first stages, and calling for expert advice, would result in its extinction before serious harm came to the trees.

The disease, although new to the Hcica as far as known, has long been an enemy to apple trees, cacao, tea, etc., and frequently kills the tree ( $r$ shrub upon which it grows. Mr. Carruthers, when first it appeared, examined portions of diseased trees, and recognized the fungus as a species of nectria. He then visited both the government plantations of Herca and the larger private plantations. In one district, Kalatura, he found only one tree in two hundred affected, but on the Edangodla estate, twenty per cent. of the trees were diseased; while at Yatiporua there were forty per cent. The appearance of the fungus on the trees is a swelling or roughening of portions of the tree trunk or branches. If the outer bark is cut off, the tissue beneath shows at first a neutral tint, and later a brownish or claret color. When the fruit of the fungus ripens, it is a very minute red dot which is carried by the wind, by water, or by tree insects, to a moist spot on the bark of the same or another tree, and there it thrives, and soon fills the tissues with its mycclium.

It was practically eradicated by cutting out the diseased portions and the burning of them. This is best done in dry weather. Nor did the cutting of the trees appear in any way to weaken then or hinder their growth. Mr. Carruthers had brought with him some cultures with which he proceeded to inoculate a young Herca tree, while I stole away into the grass with my back to the sum, turner my kodak upon him, anil pressed the button. A moment later, happening to glance downward, I saw that the grass was fairly alive with leeches, all making their way toward me. I retreated very hastily, and at once began a frantic search for them about my person. I found a lot on nyy shoes, trousers, and outer clothing. lut was lucky enough to remove the last one before getting bitten.

Speaking of insect pests, there are very few in Ceylon that are troublesome to man-at least I saw or felt but few. The mosquito was, of course, more or less in evidence, but I did not get too badly bitten. I did, however, resent its mode of attack. It does not approach you with a song, hut, in a silent, crafty, suspicions way, alights, bites, and Hees. So suspicious is the creature that it is almost impossible to clap it on the back, as is the custom in America when he has sncceeded in puncturing one's epidemis. It, therefore, has no friends, and beds everywhere are enclosed in huge muslin screens; otherwise one would be constantly boresl. 
There is also the leech. It lives, not in the water. but in the grass, and in the jungle. When exercising on an empty stomach, it is very small, alout the diancter of a knitting-needle, and from one-half to one and one-half inches in length. ()n hearing footsteps, it hastens toward the somd, getting over the ground at a surprising rate of speed for so tiny a creature, and without hesitation attacks instantly. If left to themselves, they fill themselves with blood, sivelling to the size of one's little finger, and then (trop off. Nor does this end the incident, for during their meal they inject something into the veins, which keeps

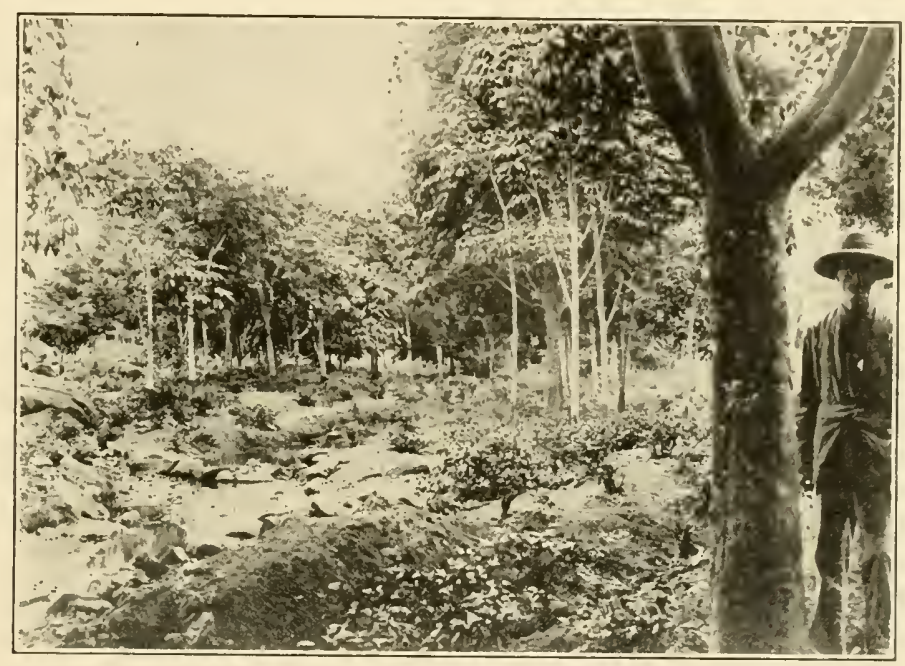

YOUNG "HETEA" TREES.

[Planted among tea along a watercourse, in Kalatura.]

the blood from clotting. and the wound therefore remains open and goes on bleeding. If roughly removed during feeding. it is rery apt to leave its teeth in the wound, which causes inflammation, and, in some cases, troublesome sores. The best way to treat them is to wear close-knit stockings, into which the lower ends of the tronser legs should be tucked. This keeps most of them off, but if they do get on one, a few drops squeezed from a fresh lime makes them let go at once. Many of the natives. who expect to encounter leeches, carry a line or two with them. Others simply pull them off, and take the chance of having an inflamed wound. In certain districts these leeches are a great pest, but as the land comes unrler cultivation, they gradually disappear. It is said 
that during the conquest of the island by the British, many a private soldier lay down in the jungle after an exhausting day's march and never awoke, his veins being literally drained dry by the swarming leeches. They are as tough as if marle of India-rulber. and about the only way to kill them is with fire. If cut in two, the separated parts will join together again, and they are always voracious, active, and absolutely devoid of fear. 


\section{THIRD IETTER.}

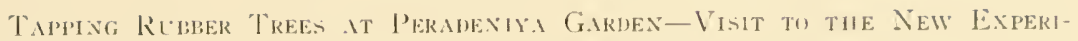
ment Staton-Senentr-file Year Oli ficus Emastici-The Stcal Speech-

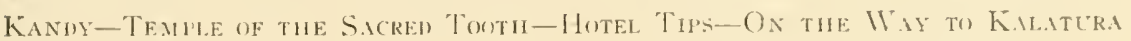

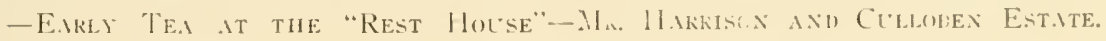

G'EAKINi again of canker, and the absence of the disease on the $D$ Sonth American Herea trees, Mr. Carruthers said that it was quite possible that individual trees there might have been attacked by it, but as the trees are wild, and grow singly, the disease, after exhausting its victin, would probably die out, as it would have no other Hi'cu

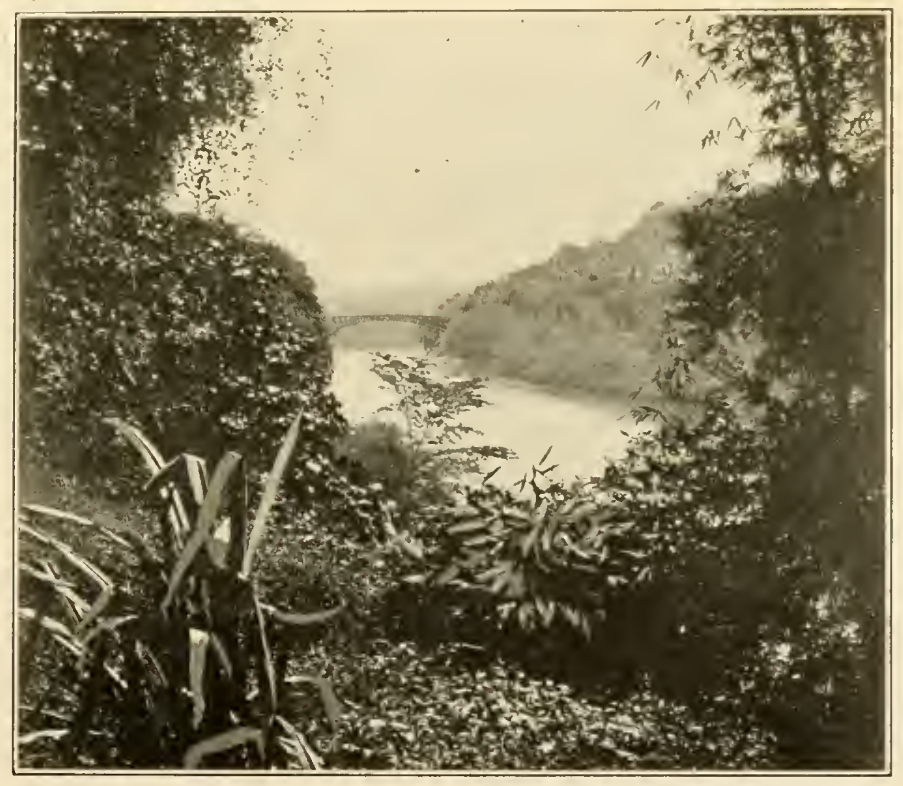

S.ITINWOOI) BRIDGE, PERADENIY.

near enough to reach. This, of course, led up to what has been proved since planting of any sort has been carried on on any considerable scale. That is, the occurrence of diseases and insects nnknown before, but which found in great plantings of a single kind the most favorable field for rapid growth and reproduction. 
It was while discussing these subjects that we visited the administration buildings of the gardens. They are neat and business like, and with their tropical setting form a very pretty picture. We visited the munseum, where sections of the woods, in which the island is very rich, are displayed; while seeds, fruits, and everything pertaining to the life of the plant growths are carefully prepared and preserved. He also showed me the offices of Director Willis, his own laboratory-where some very interesting experiments in determining the vitality of the Heica nut were then being carried on-introduced me to Mr. E. E. Green, F. E. S., the government entomologist, and then led me to some of the fifteen-year-old l'ará trees, which we tapperl. It was really too

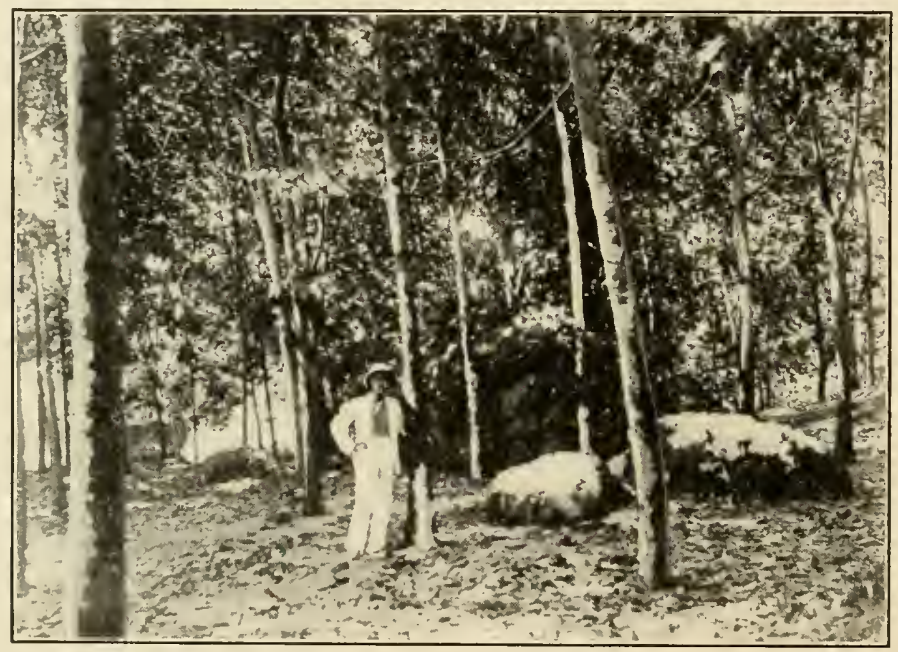

"HETEA" AT EDANGODA.

[Government Forest Department plantation, 8 years old. Mr. F. Lewis, assistant conservator of forests.]

near the middle of the day for the later to do more than ooze ont very slowly. The tool used is well known. It only needed a very few cuts with it, however, to convince me of its usefulness; incleerl. for the Hcica it is far superior to any form of machets that I lave seen. The incision is really a drawing cut that takes out a strip) of bark, laying the cambium bare. The cut is clean, small and may be made by the most unskilled coolie with but little chance of injuring the tree. I had with me a small two-bladed tapping-axe, invented by a friend in the United States, which I harl brought along to test. We all tried it, but the simple little tool far 
ontelistanced it. Leaving the collecting and straining of the letex to the coolies, Mr. Carruthers took me to his hungalow for breakfast, which meal occurs at nown, and there we discussed varions phases of rubler planting. In referring to the govermment plantations of Herea, he sair that there were alout one humeled and fifty acres now planted, and it harl not been flecided yet just how they would be administered. According to his figuring, these plantings cost about 1.200 rupees $\mid=\$ 38(1) .32\rfloor$ an acre when matured. If they are to be leased muler proper restrictions, the opinion secmed to be that the government shonld not reap more than five per cent, interest on its venture. Pint most of the experts think that it wonld be better for the wovernment to sell the plantations as near cost as possible. For further information he referred me to $\mathrm{Mr}$. F. Lewis, the assistant conservator of forests. Colombo.

The following morning we crossed the Mahaweli River, a deep. swift, muddy stream flowing by the gardens, to visit the great experiment stations that are under the charge of Mr. I lerbert Wright, A, R. C. $\therefore$ There is no bridge, so one is ferried across in a very narrow wooklen dngout, with the usual outrigger one sicle to prevent upsetting. This experiment garden is new, and contains about 1,200 acres, I believe, and takes in the native villages of Gangarnwa and Yatigalagala.

Mr. Wright kinelly piloted me over the sections devoted to rubber planting. Just to see what the Castilloa and the Ceará rubber will do in that climate moler varying conditions: he has many different plots. both in the shade and in the open. Perhaps the most interesting is the planting of the former where it is shaded by cocoanut trees. All of these rubber plots were small of course, and the trees very young, so that at the present it is impossible to say what results will be attained.

As we walked abont the place, it occurred to me to learn just how hot it was, and I found that it was $127^{\circ} \mathrm{F}$. in the sum, and the guess was that it was abont $85^{\circ}$ in the sharle. As we were in the sun most of the time, we had no reason to feel a clill.

In the afternoon, Director Willis having returned, we had a look at the Ficus clastica trees planted some seventy-five years ago. They are hunge growths, and mnlike the Straits trees of the same name, do not send down aërial roots, but instead form great root buttresses. They produce little if any later. as my own tapping experiments abundantly proved. Further than that, they are dying, so that every now and then it becomes necessary to fell one of them, for if it unexpectedly dropped its one hundred and fifty feet of length across the carriage road, a serions accident might result. 
Speaking of the Herca plantings in the island, Mr. Willis said that at that time there were about I I,OOO acres, and as the annual production of seeds was about 3.000,000, he thought that the planting increase

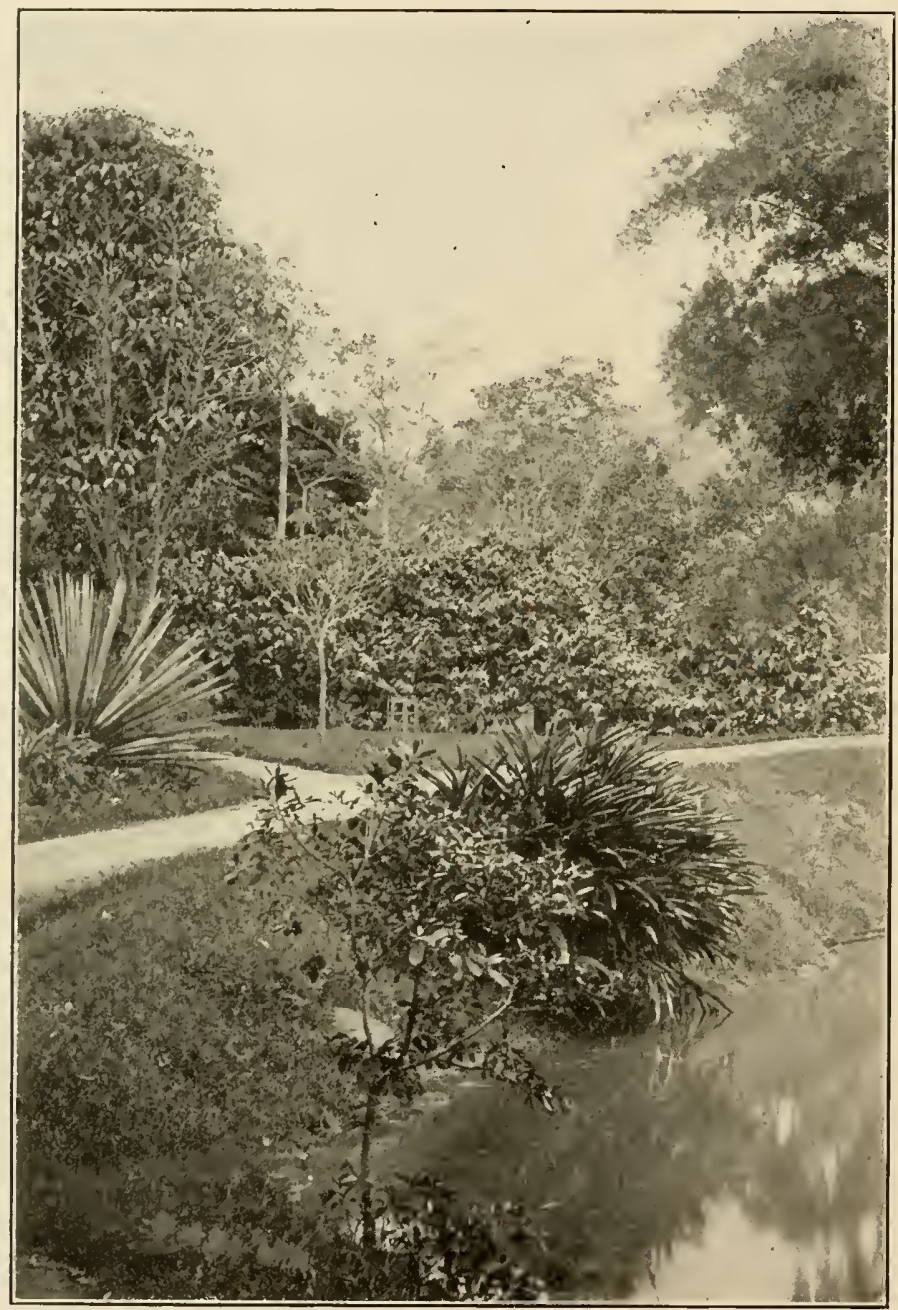

PERADENIYA GARDEN.

[Planted Castilloa clastica and cacao.]

would be about 5,000 acres annually. He said that the Herca could undoubtedly be planted in sleltered valleys, up to 4,000 feet altitude. In many situations the trees would mature more slowly, their growth repending upon the rainfall, and the richness of the soil. At Peradeniya those 
that had matured more slowly had produced latex as good and alumelant as had the others. The Castilloa hat proverl itself more tencler than he conld wish, and the general sentiment anong the planters was that it would not be as profitahle a venture. Speaking of rainfall at P'eradeniya, they could always reckon upon ninety inches quite well distributed. Labor, of course, is very cheap, ten cents a day being the regulat wage, shelter being furnished, but not food or clothing.

As an incident to this visit, I walled over the gardens, by well-kept roads, starled by magnificent trees, and visited the "lot honse" for orchids. As there is also a tea factory near the gardens. Mr. Willis

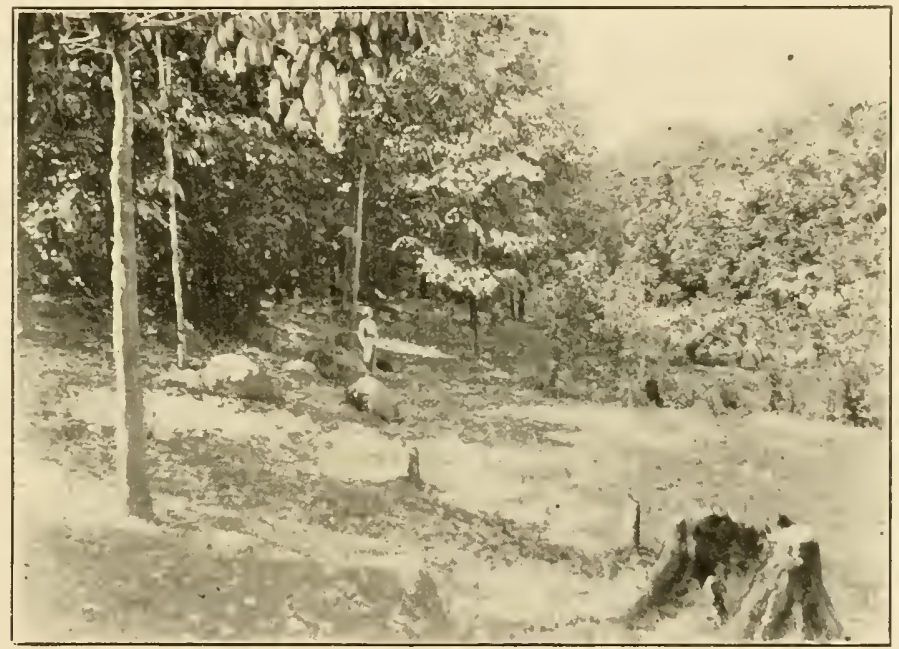

REPBER TREES KILLED BY FLOOD.

[Part of a Forest Department Hercu plantation in a valley subject to flood, showing the way in which the flooded trees died.]

was good enough to take me through that, and show me every process, the plucking. withering, rolling. drying, sorting, and packing, all of which was most interesting. After taking leave of Director Willis and his good wife, Mr. and Mrs. Carruthers, and all who had made my stay so pleasant, I took the train for Kandy, four miles away, where I planned to spend the afternoon with a steamer friend, and do a bit of sightseeing. As I waited for the train. I was conscious of careful inspection on the part of a man near me. He was a nice, well-fed, self-satisfied old gentleman, who sat by my side in one of the three cane-seated chairs that stand on the depot platform for the use of the white patrons of the railroatl. 
"Yon conkln"t have cane-bottomed chairs in a railway station in America, now, conld you?" said he to me.

"Thyy not:" I asked, much surprised.

"On account of the extraordinary habit you Americans have of standing on chairs, and making stmmp speeches," he responded with conviction.

That he was in dearl earnest, and that no denial of mine would affect his belief, one look at his comntenance showerl. It seemed a pity that he should not add to his store of knowledge along that line, so I said carelessly:

"That, of course, used to be so a few years ago. Indeed, it was a great nuisance. In public and private, at the theatre, at concerts, at receptions, even in church, stump speakers would suddenly mount chairs and harangue all in sight. It was a disease, you know, caused by a germ that was bred in the cotton fields of New Hampshire."

"Fancy!" gasped my listener.

"Oh yes, pure and simple," I continued (referring to his exclamation). The germ is known as the Septennis zocifcrens, and I may say morlestly that it was due to a little invention of my own that it is no longer feared in America."

"How interesting! And pray what was your invention?"

"Is it possible that you never heard of Pearson's Patent Orator Discomrager?" I asked with pained surprise. "It sold very well; indeed, I marle a comfortable sum out of it. Quite simple it was, but it dicl the work. It was, in a work, a semi-spherical rubber spring. so placed beneath the chair bottom that when one tried to step there, he was instanly thrown over backwarls, the shock killing the germ, but rarely injuring the man. If, however, one sat in the chair, the spring had no effect."

"Very ingenions! A most excellent device! I congratulate you!" exclaimed my listener, warmly. "Of course, it was only useful in your own comntry."

"I was coming to that. Having sold all I can in America, I am now about to prepare a foreign market for it." said.

"But-but no one makes stump speeches here, for instance!" he

"Ah, that's just it. They don't now, but they will. Our laboratory is working night and day producing healthy cultures of the germ. I am 
traveling around the world planting them everywere. They are invisible, practically. The lack of your chair this moment is covered with them where my hand rested before you came along. Ilere is my train. (rood bye."

As the train left the station, a once peaceful and self-satisfied encycloperlia of American halits, with red face and anxious mien, was stancling far away from the three clairs, and making a stump speech to a large

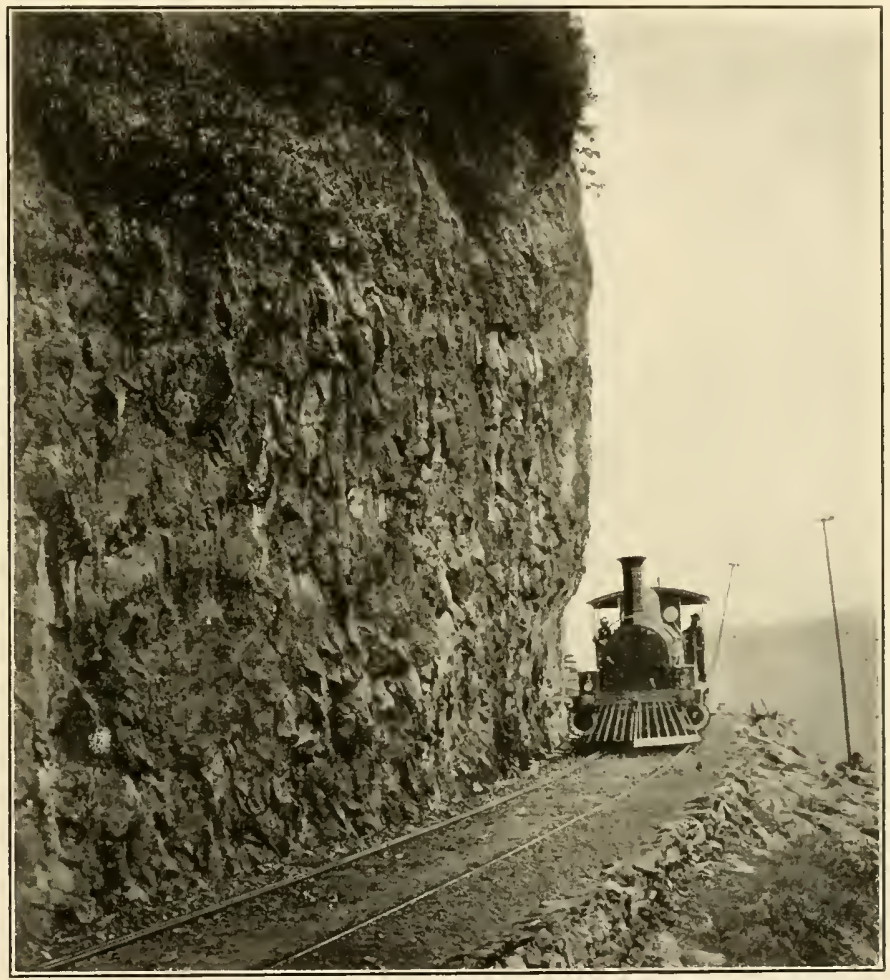

SENSATION ROCK, NEIR KANDY.

crowd of hewildered coolies. Those germs worked so quickly on him that I almost believed in their existence.

A few minutes later I was in Kandy, and comfortably established at the Queen's Hotel.

The city of Kandy (Hill town) is noted chiefly as having been the seat of the Kandyan kings, the possessor of the temple of the Sacred Tooth, and at the present time for having only one hotel, "The Queen "s." 
where a German tourist finds good entertainment for about two dollars a clay. while an American or an Englishman must pay five dollars. The city lies in a lovely valley, and is built around an artificial lake, on an island, in the middle of which once stood the royal harem. The walks and drives around the city, over heautifully lept roads that ascend with only the slighest grades, are simply ideal.

As a matter of duty. I visited the Buddhist temple of the Sacred Tooth during service. It was after nightfall. and the beating of the tomtoms and noise of conches were almost deafening. I secured a ruide at the main entrance, or rather he secured me, and, accompanied by two self-elected explainers, and a boy carrying a lighted candle, we went

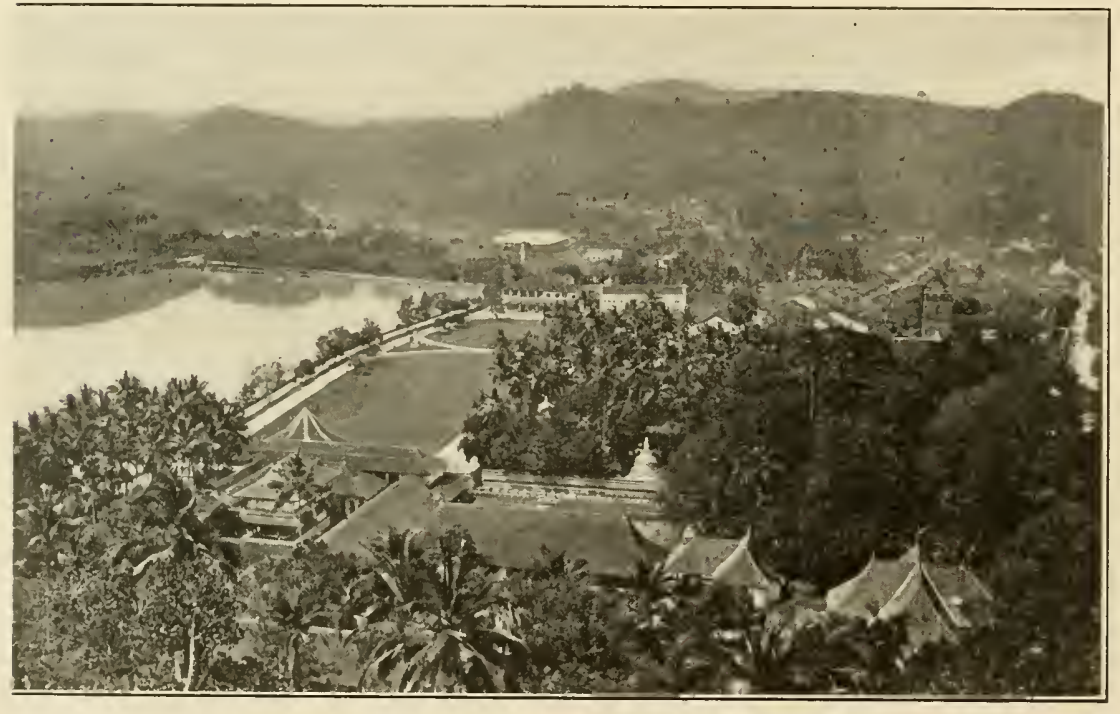

KANDY-L.ADY HORTON'S W.ILK.

from onc shrine to another, giving up contributions of small change before each, jostled by crowding worshippers, laclen with fruit and flowers.

Of the things that linger in my memory, the library of Singalese sacred literature is most prominent. There are humdreds of volumes, the leaves of the books being strips of fiber from the Tallipot palm. the letters being etched into the surface and then filled with ink. They are beautifully bound in gold and silver. and ornamented with jewels. There was also an image of the god, three feet high, of solid gold, as well as one carved out of a single block of crystal, some ten inches in height. 
Then there were copper, ivory, silver, and well carring and filigree work that would look just as well in America, but there were tor many around. I did not see the Satered Tooth, which is carefully guareler, and needs an oreler from the sovermment before one is permitted to view it. The true believers are sure that it was once a part of budclla's dental equipment, while the scientists say it belonged to a crocollile.

1 diclnt tarry long in Kandy, lut tork the morning train back to (olombo, as I now had more definite knowledge of the typical plantations, and how to reach them, as well as letters to the men in charge. l'erhaps, as a hint to others, I should say that when l left the hotel in Kandy, after paying my bill, the following servants put in a clain for tips: Bedronm man, bath man, head porter, waiter, doorman, gharri driver, the porter who puts your bas into the train, and any other native who can catch your eye.

It was early in the morning when the writer and Mignel de silval. the singalese plant collector at Peradeniya, Who was loaned me by Director Willis, entered rickshaws and started for Slave lsland station, on our way to Kalutara. For some distance the railroad follows the sea coast, disclosing the beantiful villas of Europeans, native fishing villages, and the blue sea itself. According to custom, Miguel rode with the natives, and 1, in the car reserved for the whites, was not able. to question him as I had planned. A friendly planter, however, did explain that the land over which we were passing was very valuable. through the palms which grew upon it, that were used in the production of the native liquor. "arrak." He said also that the ownership of these palms was most complex, one tree often being owned jointly by as many as five natives. I had noticed that many of them had a wattle of reeds braided about the stem some six feet from the ground, and was annsed to learn that this was to guard against thieves. It seems that the night climber cannot surmomnt this apparently flimsy barrier, nor remove it without making such a crackling that the owner is awakened sufficiently to remonstrate-usually with a knife.

Arriving at Kalutara, Mignel appeared, and with a commanding gesture secured a coolie to carry my bag, and we wended our way to the "Rest House" for breakfast. As the day was already a scorcher, its broad verandahs, square rooms, and cement floors gave one an impression of coolness which was truly grateful. Here I had "early tea." consisting of "papaya" (the luscious fruit of the paw paw tree), ham and eggs. bread, butter, and coffee-an excellent meal, the whole charge for which was, I believe, one rupee. 
After breakfast (I would say "early tea") we secured a gharri, drawn ly a horse that must have been a survival of the P'ortuguese occupation, so ancient was he, and started off for Tabeuwana, five miles away, where was another rest house. One advantage of the horse over the automolile. and the slow horse over the fast one, is that it allows one to take in the beatities of the scenery to a greater degree. The languid creature to which I had entrusted myself gave me ample chance to enjoy the cinnamon groves, the cocoanut plantations, and the paddy

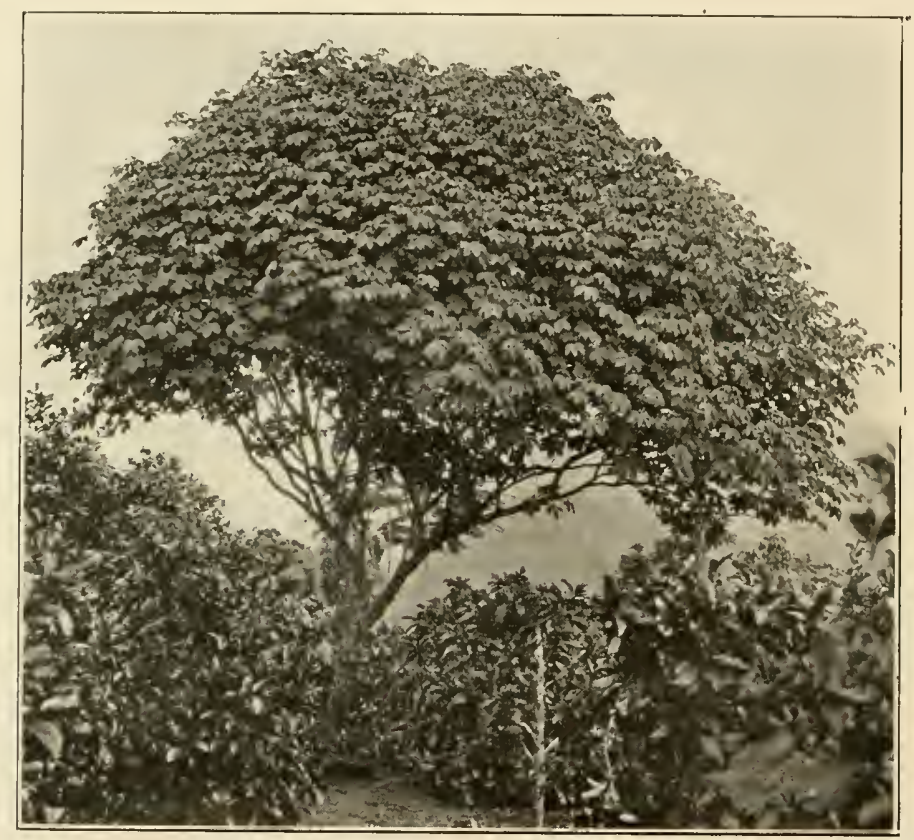

CEARA RUBBER TREE.

[At Polgahawella; planted about i886.]

fickls. Pesicles this, I was interested in the natives, and when we meanflered slowly through a village with the houses close to the road, and smelling like a fish glue factory that had soured over night, I simply held my nose, hut kept my eyes wirle open-and saw much that is not set down here. We tarried at the "Rest House" at Tabeuwana only long enough for noon breakfast and then pushed on for Culloden, which, by the way, is in Neboda, or at least that is the nearest postoffice. The roads were grood, as all in Ceylon are, and there are some 4,000 miles of them, but the scenery began to show a decided clange. The country becane more 
hilly, great masses of black gneiss showing ont through the luxuriant foliage. Finally, we ascencled a long hill, turned into a tea plantation, and leaving the gharri, followed a winding pathway to a pretty bungalow. situated where it commanded a view of much of the surromenting comntry and even wave a slimpse of the sea in the far clistance. Here I was met and welomed W Mr. R. IV. Harrison, and a neighloor, Mr. J. T. Withers, of Clontarf.

It was really too hot just then to start out to view the rubber, so we sat in huge planters" chairs that have broat shelf-like arms that

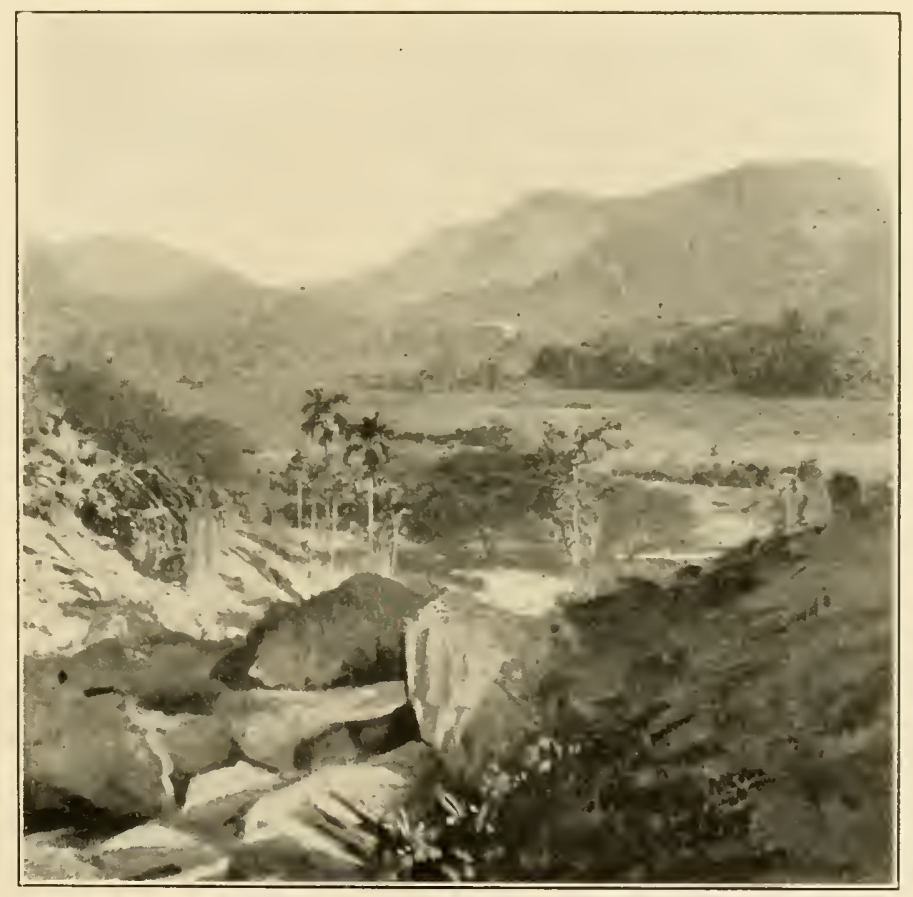

VIEW FROM HILLY ROAD NEAR CLLLODEN.

extend far out in front. arranged so that the lounger can have his feet as high as his head, and talked planting experiences.

Culloden is, of course, primarily a tea estate, beautifully laid out with fine gravel roals all over it, and not a weed to be seen at any time in all of its broad acres. Indeed, the weerling of crops in Cerlon has been reduced to an exact science. It is all done by contract, and costs thousands of pounds a year, but it effectually stops the clanger from fire that an occasional cutting of the weeds invites. 
Mr. Harrison, the manager at Culloden, is perhaps the best equipped rubber planter in the island, either from the planting or gathering standpoint. While he is in direct charge of Cullorken estate, which, in 1903, prodluced to.500 pounds of Pará rubluer, he had also supervision over the following estates: Heatherly, which producerl, the same year, 3.500 pounds ;

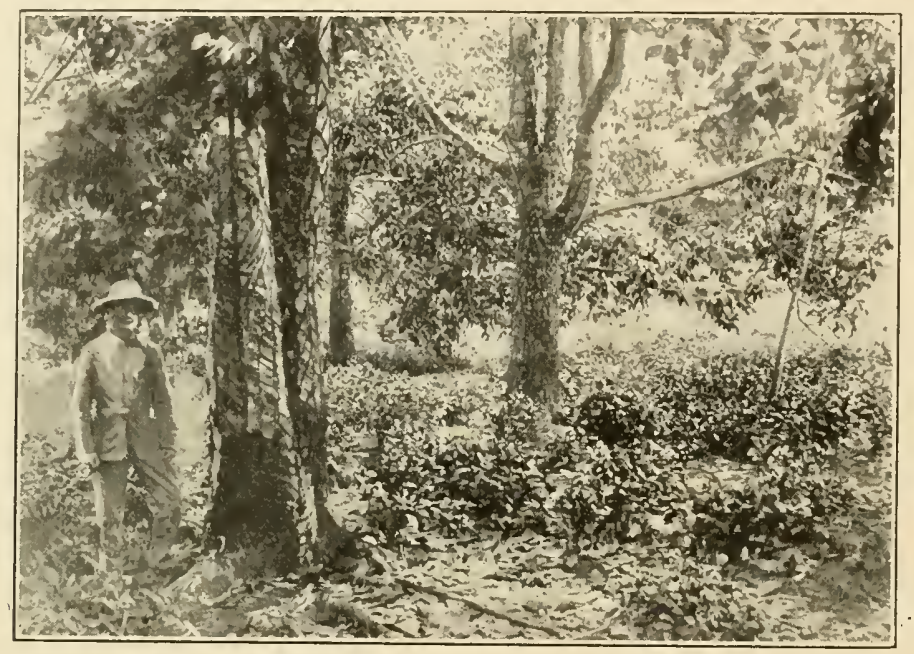

FIFTEEN YEAR OLD "HEVEA" TREES.

[Planted among tea on an estate in Kalitura.]

Tudugala, 6,00o pounds; Yatupauwa and Edengorla, 5,000 pounds. Thus it will be seen that fully one-half of the early crops of Ceylon Pará passed through his hands, and in visiting him I was sure to be at the center of the rubber planting interest. It might be well to remember also that this 25,000 pounds ammully, with a decided increase each year, came from about 20,000 trees that on an average are eight years old. 
F()KTH LETTER.

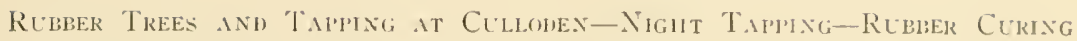

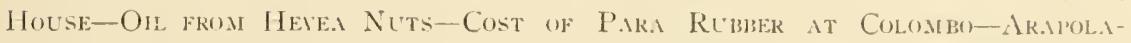

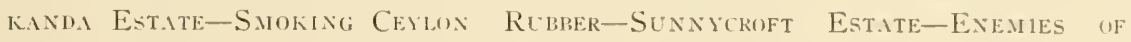
the Heved-A Touch of Feter-Tile Forest Conseryator-A Padoy Fielo EXPERIENCE.

A The close of my first day at Cullowlen, when the sun had dropped liarrison's invitation, we started out to see the rubber. The plantation is primarily for tea, the rubler having been planted later througl the tea and also in some of the valleys. The land is rery rocky, ironstone abounding, hut there must le something in the soil that suits the Heica, for it flourished wonderfully. The only place where it did not appear to do well was in very low ground, where there was no drainage. The swampy portions of the land have, therefore, been thoroughly drained; indeed, where some of the seven and eight year old rubber now is there had once been a bog where cattle were wont to get mired. The rubber on this soil, which was very rich, had some three feet of drainage. Of course, it was to be expected that the Herca would grow in such soil as this, but I must confess that I was amazed to see it flourishing far up on rocky hillsides, and sending its laterals in all directions for food. The Herea has proved itself, in Cerlon at least. a most voracions surface feeder, and in this connection it is worth while to examine the illustration of the uprooted tree held erect between two cocoanut palms, with the laterals stretched right and left, showing a growth longer than the tree trunk itself. The photograph from which my illustration was made was taken by Mr. I. B. Carruthers, and is most graphic.

The tapping of the trees begins just as soon as it is light in the morning, for through the middle of the day the later does not flow freely, but starts up again about four in the afternoon and is continned until dark. The trees are tapped when they show a girth of two feet. without regard to their age. No ladders or supports are used in tapping. as it wasn't found profitalle to tap higher than a coolie can reach while standing on the ground. The tool is a very simple $V$-shaped knife with two cutting edges, and a single slanting cut about eight inches long has been found to be best, a tin cup being placed under the lower end of 
the cut and held in position by forcing its sharp edge under the bark. These cuts, by the way, are about a foot apart, sometimes closer, and all run in the same direction, the herring bone and the $T$-shaped cuts

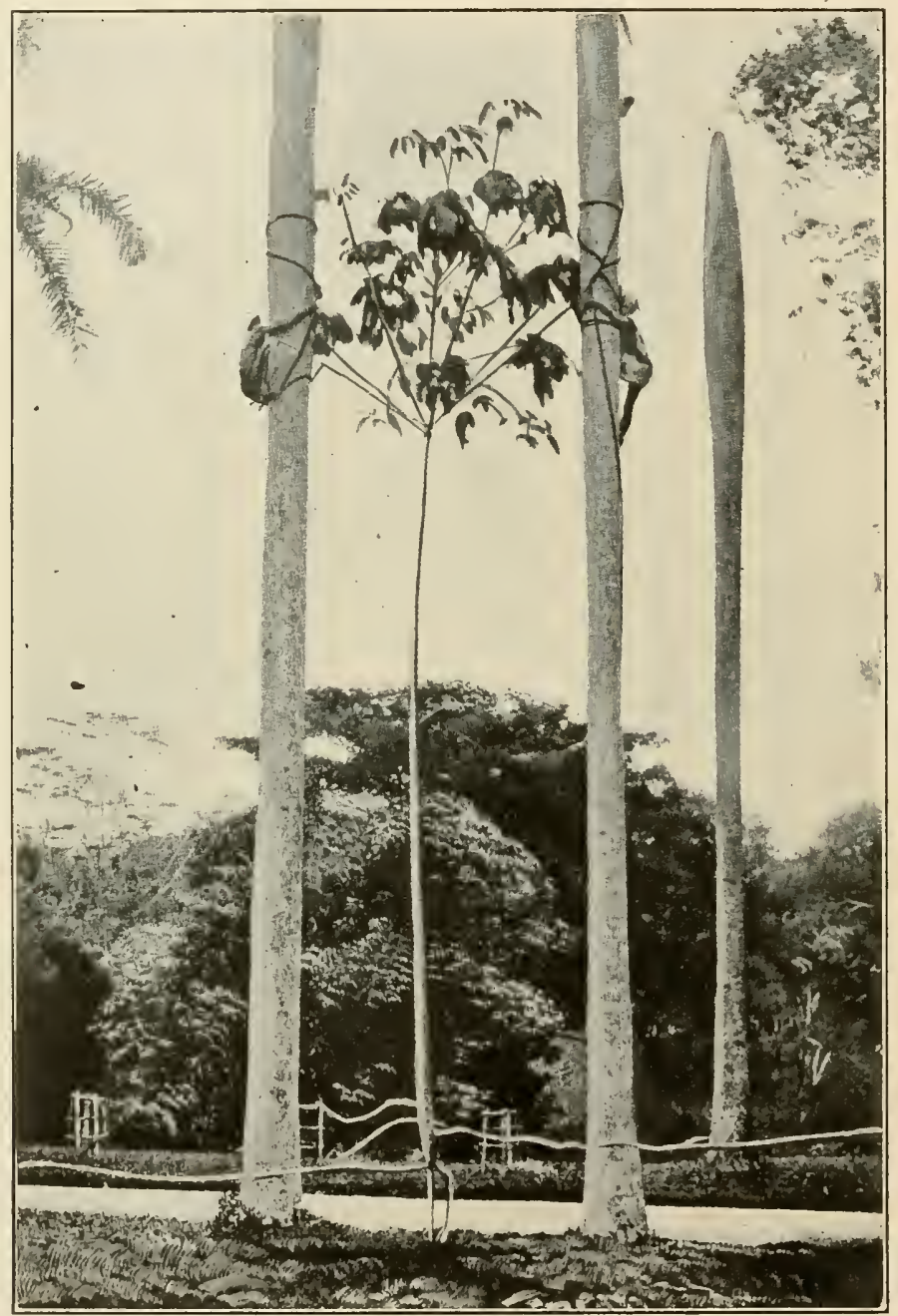

"HEVE I" RUBBER TREE.

I Suspended, to show extensive lateral root growth.|

being no more in evirlence. The practice is also followed now of cutting a very thin shaving from one side of the cut, every other day: eleven times, in other worrls, reopening instearl of tapping. Before plaeing 
the tin ent muler the cut, it is rinserl ont in cold water to lieep the later

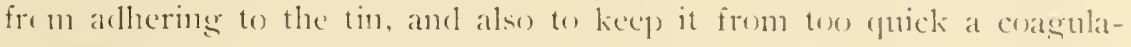
tion. While I was there, a rery interesting experiment in seraping the nnter bark from the trees harl just been finisherl. The results, as far as conld be determined, were such at stimulation to the lactiferous iluets that the How was increased nearly fifty per cent. The oldest trees on this plantation, by the way, are eighteen years, and have produced three proturls a gear: hy scraping the onter bark off they expect to get six

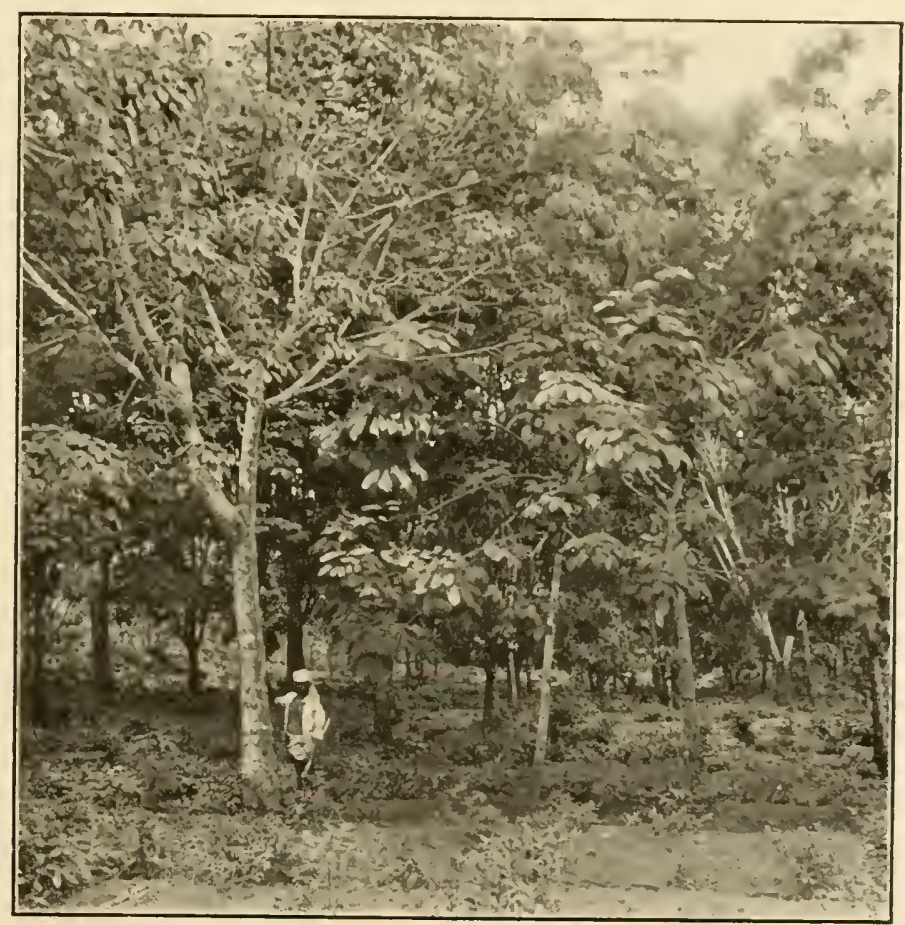

"HEVEA" TREES AT CUILODEN.

[Seven and eight years old.]

pounds a year from each of these. There are only a few of these older trees, however, most of them being seven or eight years of age. All through the rubher orchards on this estate were hundreds of romms Pará trees that were self sown; indeed in many places they had come up so thickly as to be a nuisance. The workmen on this estate, one hundred in number, are all Tamil coolies, as the Singalese do not care to work, preferring to cultivate rice, a good crop of which insures them 
a two or three years' vacation. By the time we had examined a few Castilloa trees that were planted by way of experiment, night had fallen, and we wencled our way back to the hungalow, where, after a hot bath, as is the custom of the country, we sat down to dimner in pajamas, the "punkah walla" stirring the heary, moist air by most vigorous pulls at the "punkah" cord throughout th, meal.

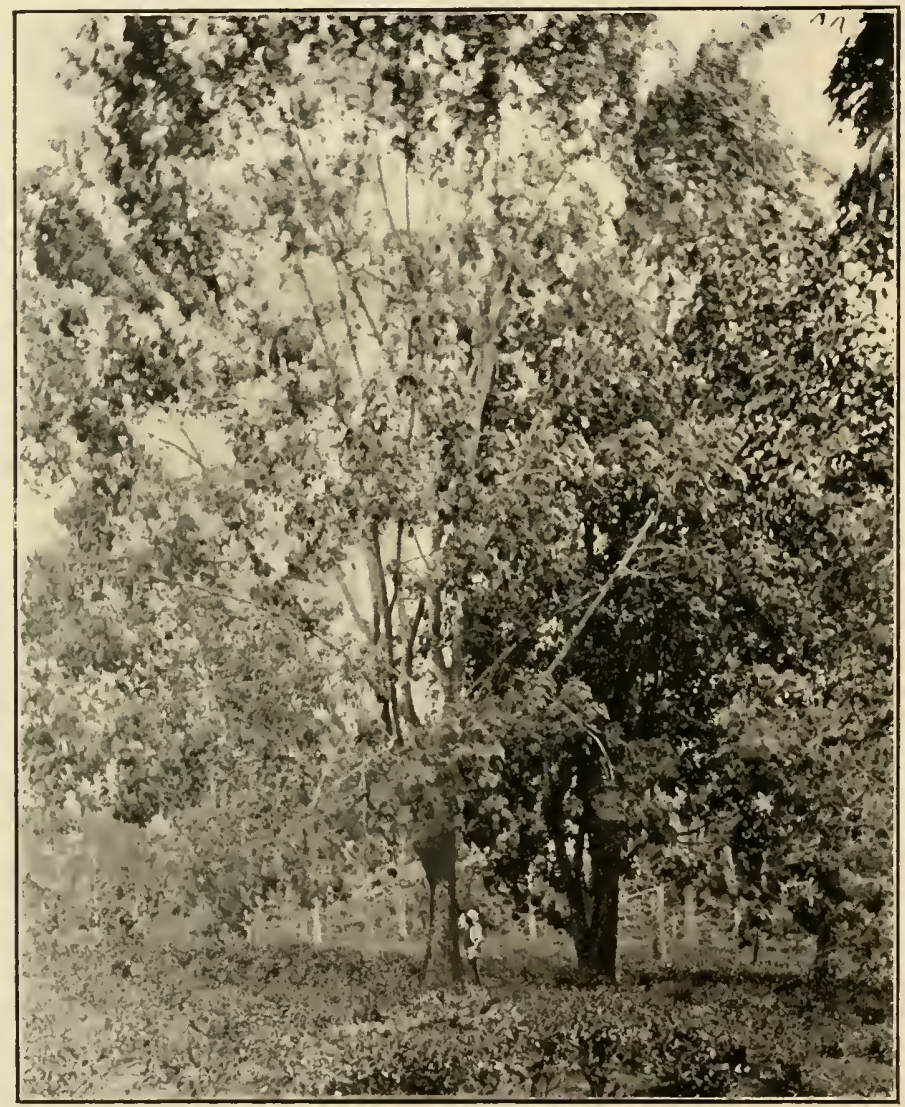

"HEVEA" TREes AT CULLODEN

[Eighteen years old from planting.]

The rainfall up here in Kalutara is rather more than down at the coast, being, so I was informed, one hundred and forty-four inches, and the maximum temperature $94^{\circ} \mathrm{F}$. W'hile I was there it was unusually dry, yet the rubber looked well and there was a record of six weeks without rain, which had no apparent effect upon it. The next morning we 
visited other parts of the plantation, and saw a great deat of the rulber. At present there is an excellent market for the seed, as so many new plantations are going in. As a better preparation. luwever, against the time when the seed will be a drug in the market, my host was experimenting with an oil marke from the seeds. With a rucle native mill he turned out an oil which the native women eagerly purchased to burn lefore their gols. while the pressed cake made an exeellent food for cattle. During the forenoon I saw a large Ceará rubler tree cut down and it seemed to have no later in it at all. I also sall a l'arcí mubber tree,

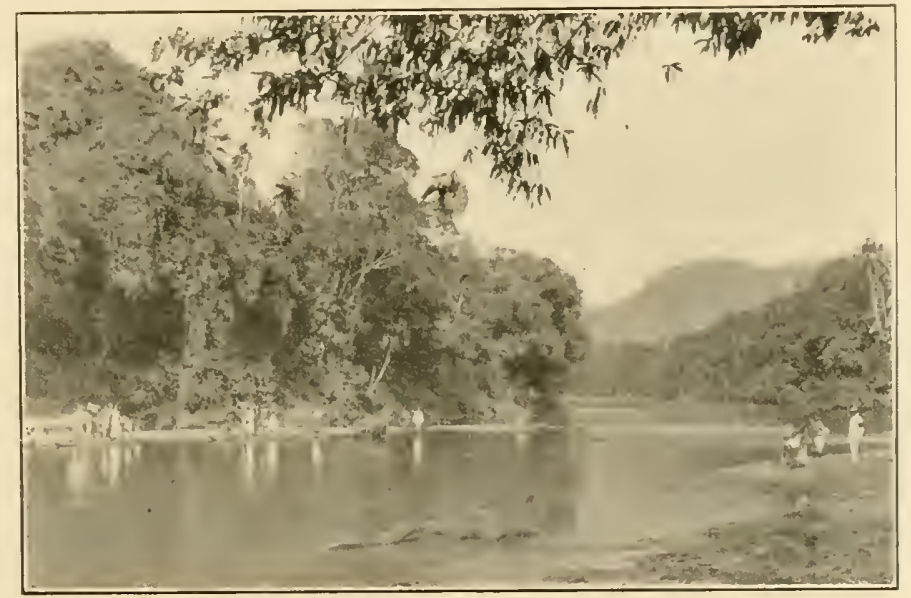

SCENE IN KELANI VILLEY, CEILON.

self sown, growing out of a cleft in the rock where there was apparently no soil, the trunk being ten inches in diameter and apparntly very thrifty:

One of the most interesting features of this plantation was the rubiber curing house, where the milk is coagulated and the rubher prepared for market. This is a one-story, brick building, $30 \times 80$ feet. smelling for all the world like a dairy, as one steps within its doors. At one end of the room is a long table upon which are hundreds of enamelled iron pans, capable of holding about a quart each. Into these pans the milk is poured through a cheese cloth strainer, after having been previously strained in the field. To it is often adcled a very little acetic acid - a fei drops only. This is allowed to stand over night, and in the morning there is to be found in each pan a pure white pancake of rubber, soft. spongy, and full of water. Each cake is rolled on a zinc-covered 
table with a hand roller and much of the water thus expressed. The name of the estate is then stamped mpon it with either a wooken or metal die, when it is ready for the heater room. The heaters used are simply charcoal ovens, the rubber being spread on wire screens above the fire, and left for three or fonr hours. By this time the pancalies have lost about 50 per cent. in weight and are beginning to assume a recidedly (larker hue. Cakes in the condition described, if in South America, would be immeliately marketerl, lunt not in Ceylon. From the heaters they go * to drying racks, where they are air dried for a month or six weeks, the

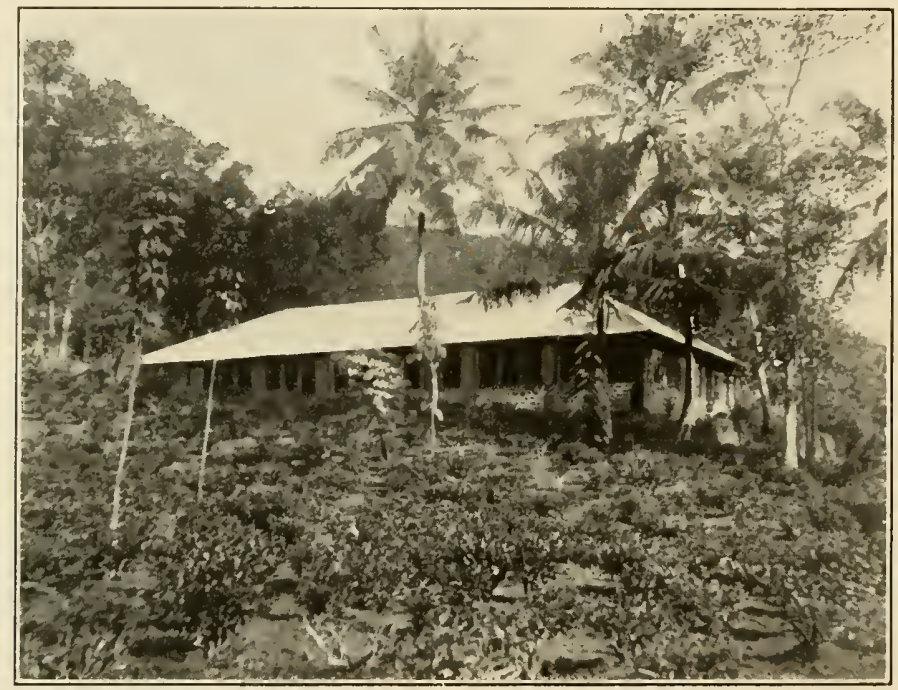

RL'IBER CURING HOUSE, CULLODEN.

time depending somewhat wpon the weather, and are shipped only after careful examination as to quality and dryness. The care which the planters are expending upon the preparation of the rubber is the best sort of guarantee that the quality will be sustained, and that the day will come when the name of a plantation on a cake of rubber will tell its value almost to a penny. To follow the rubber a little further, it is, when perfectly satisfactory to the planter, packed in chests, the connterpart of the regulation tea chest, made of "moni" wood that comes in shooks from Japan, each package containing about two hundred pounds.

There is also a coarse rubber that is secured by picking the scrap from tapperl trees. It is a very excellent rubber, and while I was there it found a market at $3 s .5 \frac{1}{2} d$. , while the fine was bringing $4 s$. $9 \frac{1}{2} d$. There 
are those who chain that it is mure to pick the film of rubler ont of the tapping wounds in the tree, as there is danger that insects or disease enter there. Such a theory is platusible, but so far I have not heard of ill resulting from such removal of the air dried scralp).

This coarse rubler, by the way, was not alsolutely clean; that is, it contained luits of hark, and vegetable matter oftentines. As labor is so cheap, and there is plenty of water, it conld be very casily washed. For this purpose the ordinary corrugated roll washer that is used in the rubber factories has been suggested, but it hardly fits the case, as the seraps are so very small. A more practical plan would be to rum them through a winnowing machine such as is used to blow the dirt out of

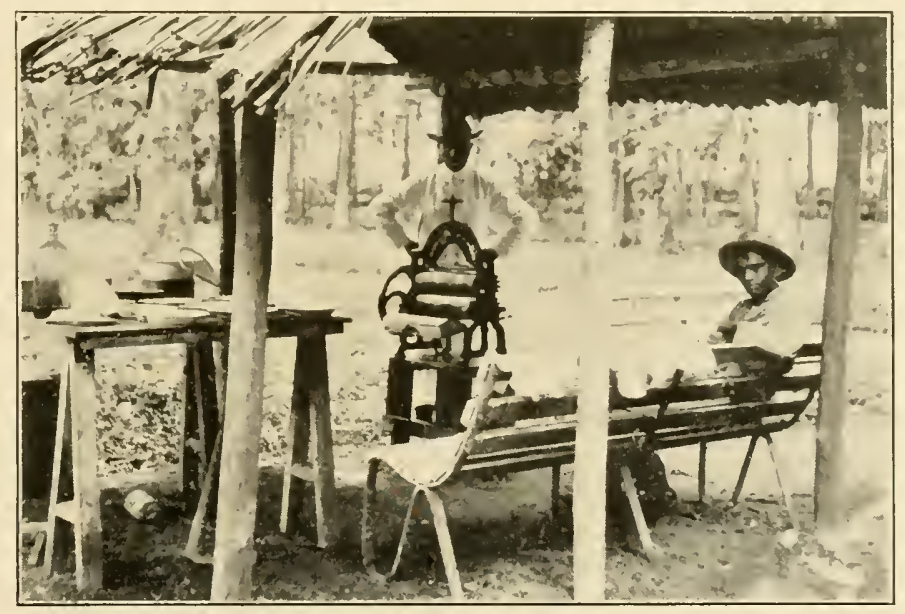

COAGULATING AND PRESSING PARA RLBPER.

peas and heans and let the air blast take out as much bark as possible. Then, if necessary, use a washer of the paper engine type to wash and beat the rest out. Of course, for quick drying, the gum should then be sheeted, and either plain or corrugated rolls would accomplish that, and it conil hang until dry. There is so little of the scrap, however, that the simp?e wimnowing machine is probably all that would be necessary or profitable.

The time will come, however, when the coagulating and drying will have to be done on a different plan. The present method takes up too much room and is too slow. It would be perfectly easy to have coagulating pans that would deliver strips of rubber ten feet long, a foot wide, and a quarter of an inch thick. These strips could then be rum 
through rolls that would squeeze the excess water out, and at the same time imprint the plantation name every few inches. Then the strips could be hung up to dry and any degree of artificial heat applied that was thought best.

There have been suggested, also, a variety of quick coagulating devices, such as endless belts that take a filn of milk into a drying chanber and deliver it to the other side coagulated and drierl. Some such plan may prevail, but as yet the planters are not ready for it.

After many experiments the manager at Culloden has satisfied himself that only the very early morning or the late afternoon are the proper

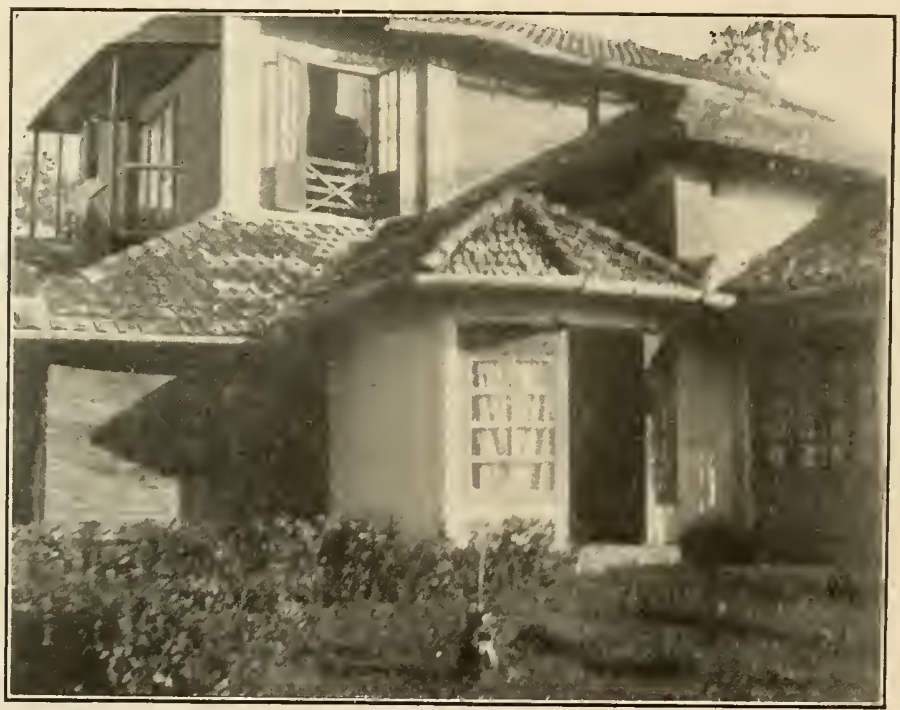

MR. HARRISON'S BUNGALOW, CULLODEN.

times to tap, as in the middle of the day the flow of later is almost nothing. The trees are therefore tapped from 4 until $7 \AA$. 1. , and after 3.3O I. 1r. and as long as it is light. Indeerl, the collection of the latex is often done by torchlight. As an instance of Mr. Harrison's alertness in getting all he can ont of the trees with safety, he told me of a scries of experiments that he was about to institute for all niglit tapping. It seems he learned that certain sugar estates did all their cutting of the cane by electric light, and that the amount of saccharine matter secured was nunch larger than in the daytime, and as the habit of the Heica tree 
peinted tomarel more later at night he felt that a similar experinent wotilel be justified.

It the present time he keeps a careful record of the prosluetion of each tree and for this purjose the trees are mumbered. When a tree has a circunference of thirty incles it is fit to tap, whether it is five.

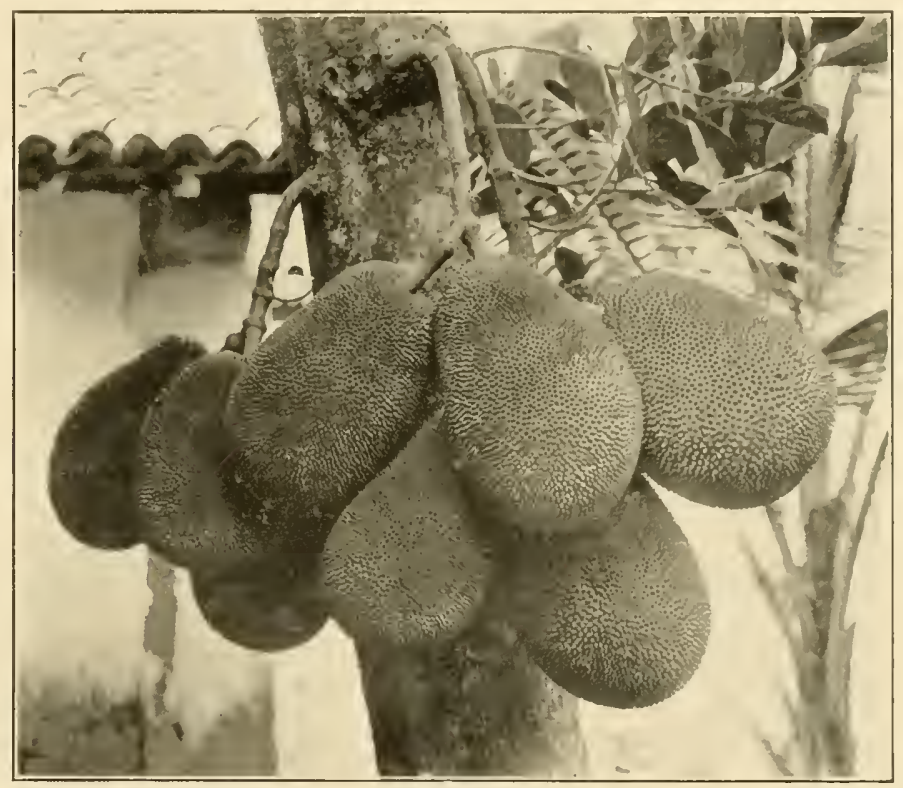

J.IK FRUIT.

six, seven, or more years old. His first year's tapping in loji was 4.010 trees, from which he secured 4.600 pounds of first quality Pará. In 1902 the production was about the same, the production for 1903 from 8,300 trees being 10,500 pounds. From 2,500 trees on Heatherly. which have just come in bearing, lie gets 3.500 pounds.

To show how thoroughly. Mr. Harrison is seeking for knowledge of the Herea, he has even had the leaves analyzed to know just what they get in the way of food from the soil of Culloden. The analysis is as follows:

Fresh. Air Dried.

Moisture .....90.605\%, 10.600\%

()rganic matter . $8.510^{\circ}, 85.150 \%$

Ash $\ldots . . . .8 .8+9 \% \quad+.250 \%$

The analysis of the organic matter showed that it contained 3.606 per cent. of nitrogen, while the ash showed as follows: 
. Potash $\ldots \ldots \ldots \ldots \ldots .1 .320 \%$

Phosphoric acid .........398\%
Lime $\ldots \ldots \ldots \ldots \ldots \ldots . .08+\ldots$ Magnesia $\ldots \ldots \ldots \ldots \ldots 2.1 \mathbf{i}^{\prime \prime}, 0$

Hence I.000 pounds dried leaves would contain about four pounds phosphoric acid; 13.2 pounds potash; .8 pounds lime: 2 I.I pounds magnesia: and thirty-seven pounds nitrogen. Fron this it will be seen that the leaf is curiously rich in magnesia, but whether from selection or force of circumstances it is difficult to say.

Nost of the work is done by contract, each coolie being expected to get late. enongh to produce one pound of dried rublber a day. It is

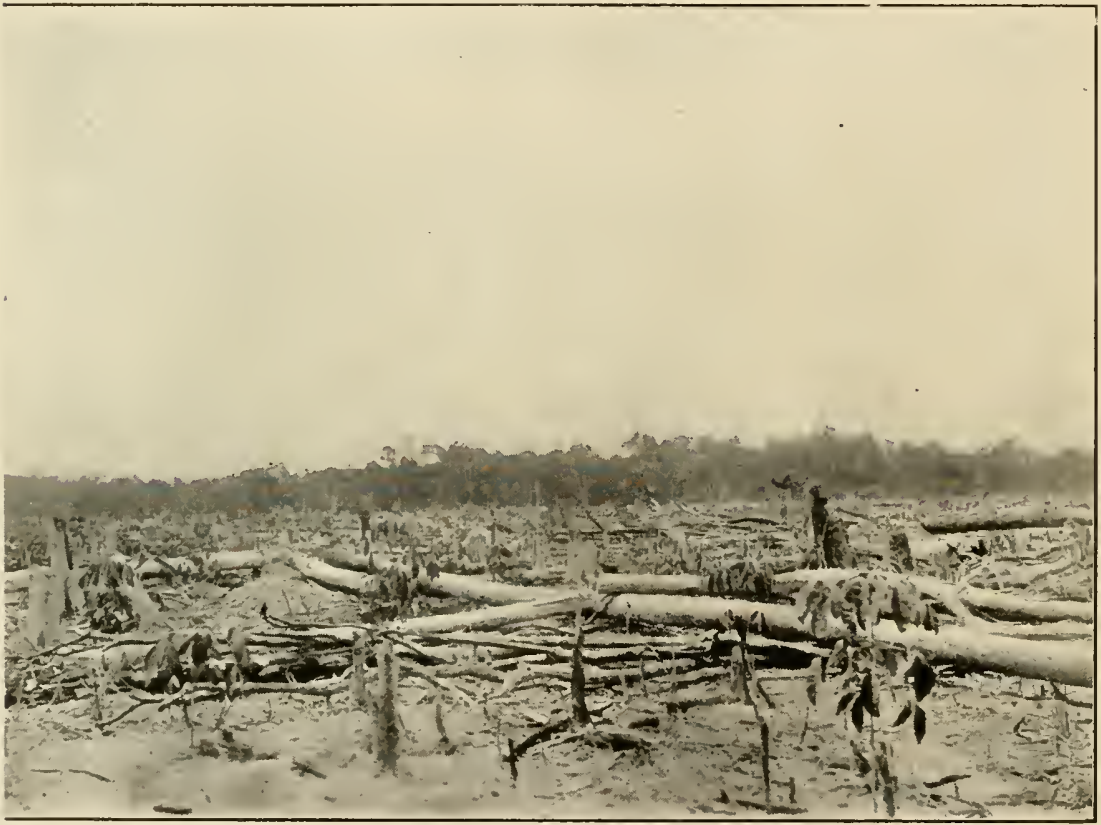

VIEW OF "HEVEI" SIX MONTHS AFTER I'LANTING.

very interesting to watch them as they troop up to the curing house early in the forenoon, with huge tin cans of late.t on their heads, and to note how they watch the straining that none is slopped over, and even rinse cups, cans, and every receptacle and add it to the rest that no precious drop escape.

The rubler landed in Colombo costs sixteen cents a pouncl, Lnited States money. Just to let the skeptical do a little bit of thinking, and by the skeptical I mean the majority of rubber mantufacturers who 
believe that the Para from the Amazon is a better business propositionjust to start them thinking. therefore, I want to ask them to rearl the following:

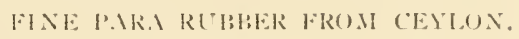

Sells at Liverponl, per pound. . . . . . . . . . . . . . . \$1.20

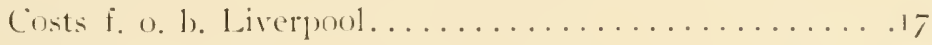

Export duty ......................... 17

l'lanters profit ................\$1.03

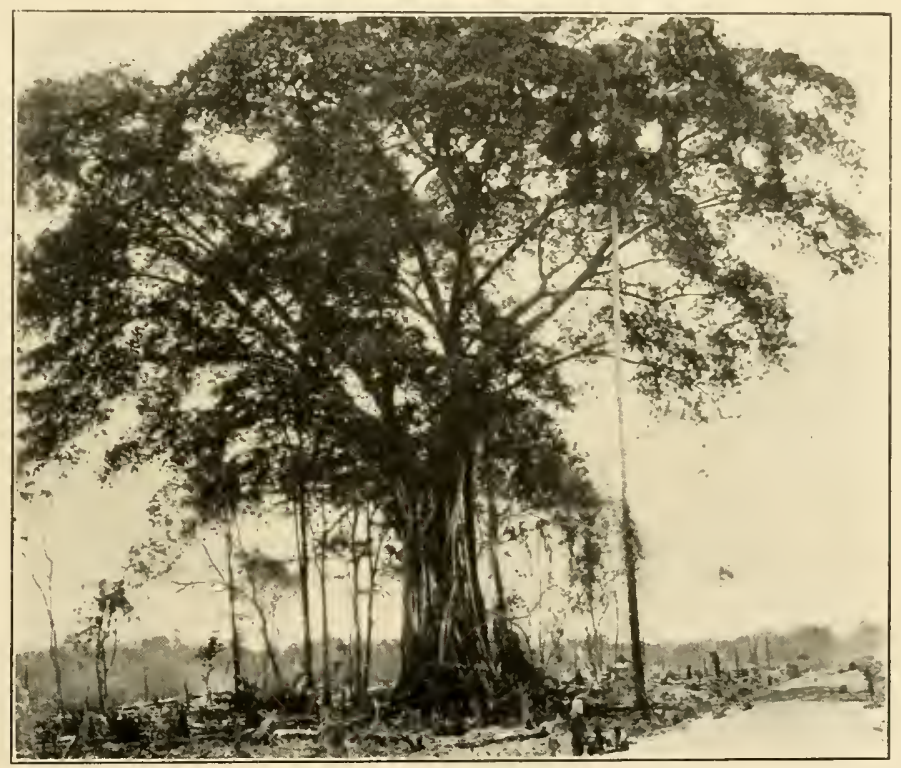

WILD "FICLS EL.ISTIC.A."

FINE P'IR.I RLIBEK FRONE HR.IZIL.

Sells at Liverpool, per pound ................... \$ \$ .0o

Costs f. o. b. Liverpool, minimum............... . I

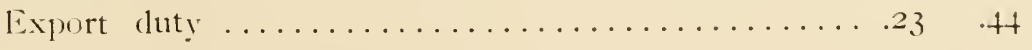

Profit $\ldots \ldots \ldots \ldots \ldots \ldots \ldots \ldots \ldots \ldots \ldots \ldots \ldots \ldots \ldots \ldots$

The above figures both for Ceylon and South America are very small-that is the cost figures. It is probable that twenty cents a pound 
for cost in Ceylon would be nearer actual practise, while Pará rubber costs, landed in Pará or Manáos, often forty, fifty, and sixty cents a pound, the figures being dependent upon the section that it connes from.

As a matter of fact, the Tamil coolie whom the planters employ is not a high salaried individual. His pay averages about thirteen cents a rlay. Lnited States money. To this is adderl the coolie "lines" or houses which are free of rent to him. as is also medical attendance. The planters keep no stores usually, lint they do buy rice and furnish it at

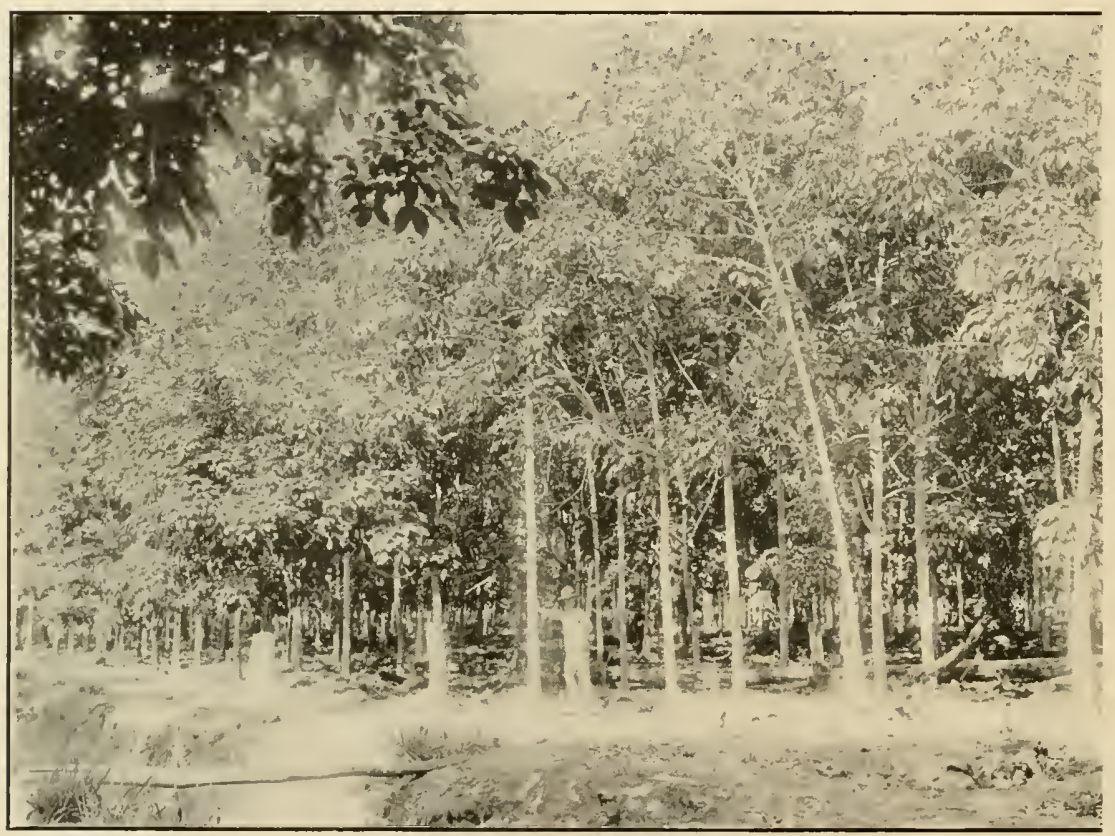

"HEVEA" ILANTED I8S9: PHOTOGRAPHFD I9O3.

cost to their laborers, the allowance heing one bushcl a week for a man, and three-cuarters of a bushel for a woman.

It was while sitting on the conl flags under the broarl porch at the Harrison bungalow that the subject of suakes came up. Hoth my host and his friend acknowledged that cobras were very plentiful, and that they had a great liking for cool bungalows, which they sought to enter whenever they thought they could safely do so. They said it was a very rare thing. however, for a white man to be bitten by one. But the natives are often bitten, and sometimes fatal!y. The Singalese won't 
kill them, as they think the cobra quite likely to prosess the soul of sone dead relative of theirs. The Tamils, however, have no such prejuclice and are perfectly willing to slatghter them whenever they can. My informants acknowledger that the bite of the cobra was very venomots. but not necessarily fatal. They said that some years before there hat lived in that district at man who was known as the colora king. who not only cured snalie bites in otlers, but was pronf against poison hinself. He used to tease the snakes to make them bite him, and even rul, their venom into cuts on his arms. and apparently without the least injury. Lut he was finally attacked loy a sort of rhembatism, which made him a helpless cripple, and he went hack to England to get cured.

Close to Culloden is Arapolakanda, where I next risited, being entertained by the resilent manager, Mr. H. L. Bagot. He las but fifteen acres of Heied in bearing. and gets twenty pounds a day. In coagulating. Mr. Bagot dicl not follow exactly the process used by his neighbor, Mr. Harrison, the difference being this: he added no acid to lasten coagulation, and also smoked the rubler over a fire of sandust and bark. The final drying was accomplished by spreading on wire screens, and not a ponnd was shipped until it was perfectly dry and transparent. By the way, he reported that he had one "dumb" tree that was big. thrifty, and apparently exactly like the others, but that it gave no milk. At the lower end of Arapolakanda are some acres of marsh land that have been drained and reclaimed and on which is standing some fine rubber. As this land is near the river. it is sometimes inmulated, the water standing four feet up on the trunks, but for a short time only. Mr. Bagot acknowledged that the trees were set back somewhat, but not very much. The general opinion in Ceylon, howerer, is that inundations are very apt to kill out the Heica.

The olclest rubber on this plantation is some fifteen to eighteen years old, planted quite closely together in a sheltered nook. In this lot the outside trees which get the sun are by far the largest, one that I measured roughly being two feet in diameter and sixty feet high. After having seen all of the rubber, I examined the tea, saw what sights there were, and spent a very pleasant evening with Mr. Bagot, at whose bungalow I slept.

Very early the next morning, with a coolie carring my luggage, I made ny way to the river and climbing down its steep, clayey bank, fouml myself aboard the steamer Kaluganga. This craft was some sixty feet long and twelve feet wide, with a small wood-burning boiler and engine amidslips. The forward deck was reserved for the whites, 
while the blacks huddled together at the stern. I had harely cmbarked, when down cane one of Mr. Wither's coolies with two steamer chairs, one of which he harl thoughtfully brought for me. After a most earsplitting whistle, the little steanner cast off and starterl down the deep, muddy stream. Shortly after leaving the pier, we passed the Clyde estate, which slows a large planting of tea and Pari rubber, the trees young, straight, and tall. The run down the river was a pleasant one,

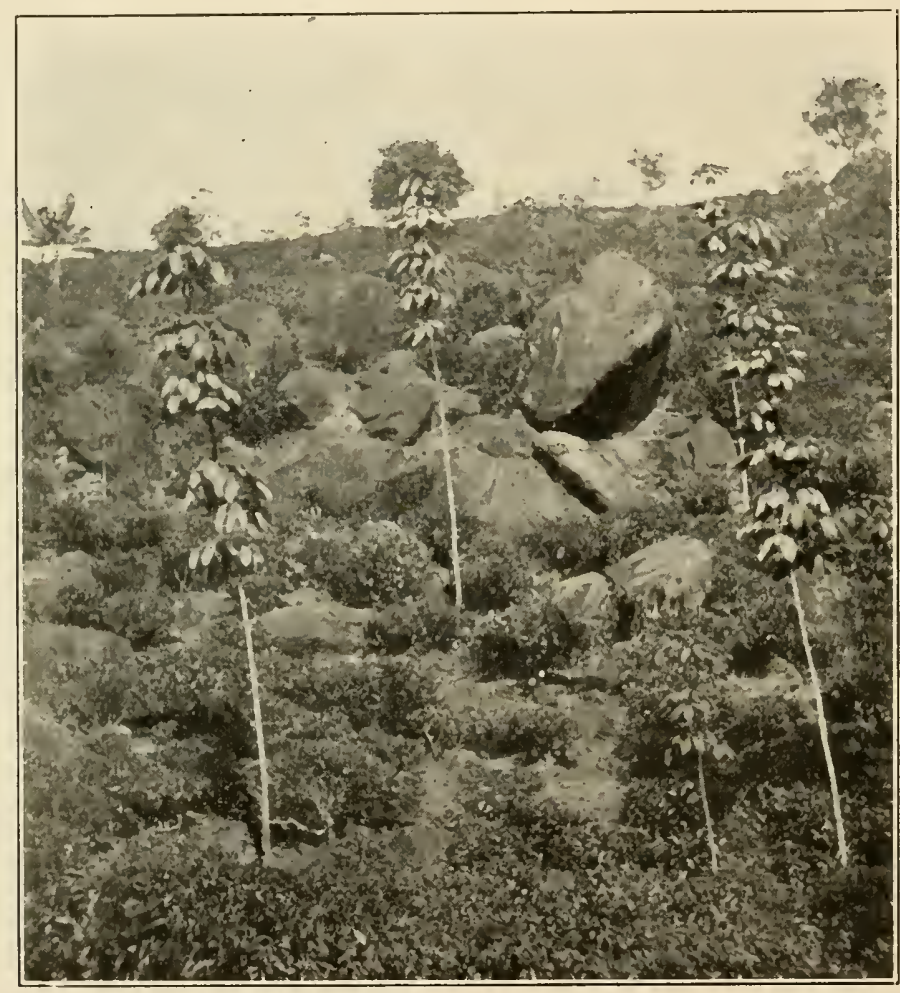

"HEVEA" TREES AT SUNXYCROFT.

but in no way exciting, and early in the forenoon I took a train from Kalutara and was again back in Colombo. As I plammed to leave for the Kelani Valley that afternoon, I went to the Grand Oriental Hotel for breakfast and a sicsta. from which I was awakened ly a pleasant young reporter, who interviewed ne most thoronglily. I want to say in passing that all through the Fast the newspaper men seemed alive to the inportance of the rubber question, and printed nuany columus of 


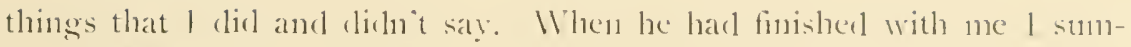
monerl Nliguel and we took rickshaws for Mararlana Junction station and there bouglut tickets for kiarazurella. After a somewhat tiresone ricle in the train we reacheel our lestination and I found Mr. IV. Forsythe, of the Sumueroft estate, awaiting me with a very swell rig consisting of a fine horse and high cart. Into the trap I got, andl Mignel hiring a bullock hackery, we drove merrily off. The Forsythe conveyance soon left the other far behinel, and as evening fell and it bexan to grow chilly, 1 was movel to ask how much further Sumneroft might be. I then learned that it was eight miles from the station, whereas I had been told that it was two. As the road was constantly ascending. it grew colder and colder, and as Mignel had my coat. I suggested to Mr. Forsythe that I was in for a chill. He therefore stopped at the bungalow of a planter friend and secured a coat for me and our jounney was then continued. I lad it not heen for the elill in the air. I should have enjoyed the ride mightily, as the roat was most picturesque. winding through native villages. crossing rivers and often crowded with strange conveyances. Mr. Forsythe entertained me very pleasantly that night, and the next morning we walked some eight miles over his plantation. His land was exceedingly hilly, but moder a high state of cultivation. showing many hundreds of acres of fine tea. He also had about three hundred Hoea trees planted in i 897 , which would average forty inches in circumference. In addition to this he had planted rubler everyhere through his tea, but very little of it was over two years old. In his section he found that when the Herea trees were young it was a constant fight to keep the porcupines and wild pigs from eating them. He was, therefore, protecting the young trees in certain sections with wire fences, the lower sides of which were buried in the gromnd.

It was during this walk that I discovered what it meant to get chilled in a tropical climate, and to have the chill develop into an incipient fever. Although the sun was seorching hot and I was exercising. I wasnt perspiring a particle. When we got back to the bungalow in the early afternoon, therefore, after due apology for being ill. I took twenty grains of quinine, and wrapping myself in blankets, went to sleep. The quinine or the blankets did the business, and the next morning I was able to take a bullock hackery at five oclock and rattle and bump down the mountain road to the railroad station, whence I took train for Colombo.

The next day I was fortunate enough to meet Mr. F. Lewis, the assistant conservator of forests, who has done a great deal to further 
the planting interests in Ceylon, and whose opinions on rubler are most sound. In the course of conversation, he acknowledged that he and his coworkers were continually on the outlook for the appearance of disease in the rubber. He said that wherever large areas of anything were cultivated, nature came forward with some disease or pest. He believed, however, that intelligence and vigilance would keep such visitations at least under control. I asked him specifically about his idea of distances in planting rubber, and his conclusions were almost identical with my own, that it was well to plant closely at first, that weeds and grass might be kept down, and perhaps cut out the weaklings later. Of course, in planting through tea no such close setting can be indulged in.

My visit to Ceylon was drawing rapidly to a close, as I was booked to sail on the Bungal on the 2oth. Any further excursions that I took into the country were, therefore, of minor importance, and of adventures I had none except that little affair with the water buffalo. It came about through my desire to see a paddy field at close range. I was some little way out of town, and stepping down off the roadway walked out on the narrow bank of clayey mud that separated one rice plot from another. There were hundreds of these plots and miles of narrow earthworks, and I had gotten some distance out, when a huge water buffalo, wallowing in the mud, made up his mind that I was an intruler, and started for me. As he weighed about a ton, and knew the country anyhow, I didn't stop to argue, but raced back for the road. I an considered a pretty fair rumner, but I verily believe that the beast wonld have caught me if it hadn't been for a native who ran out with a switch and headed him off. The absurd part of it was that my rescuer was a mite of a boy, his only clothing being a red string round his waist. but he certainly knew the proper profanity to apply to water buffaloes. By the way, speaking of paddy fields, it seems a shame that the very best land of Ceylon should be given up to the culture of rice. If those same fields were drained and planted to Pará rubler, there is no doubt but that they would show an infinitely bigger profit, even if those who turned them into rubler orchards paid, as an annual rental, the amount of rice that they are supposed to produce. 


\section{FITH HETTER.}

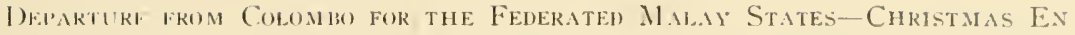
Route-Arriyil. at Singarore-The Potanic Garbens and Director RinleySuccessfel Growth of Helea-Gathering Gutta-jeletong in the JungleRebohling Gotta-PERcha by the Chinese-A Vist To Johore-Starting for SALANGOR.

second experience on a P. and (). boat was when I boarderl the Bengal in Colombo harbor, leing taken off in a catannaran, whose crew secmed to enjoy narrow escapes so much that they invited collision with every moving craft that came their way. Reference to my notes develops one fact that scemed of prime importance then, and that was that I sailed from Colombo on the 2oth of December, and hat received no mail at all while in Ceylon. In other words. I had got ahead of scherlule time, and as a result was facing (hristmas on a tropical sea with no holiday greetings. However, the Bengal sailed just the same. We got away soon after dark during an exceedingly heavy rainfall. As there were only twelve passengers all told. I had a very roomy, four-berth cabin to myself-a great comfort in tropical waters.

The next morning I was up very early, took my last look at the fading shores of Ceylon, and got well acyuainted with a young planter from Penang who was so much interested in India-rubber that he described to me in detail the way the American importers bought it. "melted it up with sulphur and lamplack and sold it to the manufacturers to be cast into goods." As we were still working south, the heat became even more tropical, ret we were forced to take much exercise to enjoy our meals. Ne therefore played ping pong. deck quoits, and cricket. being every now and then driven to the smoking room by the floods of water that poured along the decks, in spite of top and side awnings. The air was exceelingly clamp: one perspired constantly, and. as one Briton expressed it, he felt like a chewerl string. On December 24. we sighted the island of Puloh Wea, which, having no awnings over it, was getting mighty wet, and on the following morning. which was Christmas, we entered the harbor at Penang at 6.30 oclock.

The rain had left us for a little, the sea was smooth, and all about ns were lirown-sailerl Chinese junks and sampans with double pointeal sterns. on which stood half naked dyaks with queer conical hats, sculling with exceeding skill. The harbor was croweled with forcign shipping. 
all gaily decorated with flags, and as we cast anchor we had a good view of the town nestling at the foot of lofty momtains covered with verdure to their very summits. We all got ready to go ashore and stood watching the swarming native boats containing money changers, curio sellers and jugglers. These gentry were not supposed to come aboard, but whenever they got a chance they ran their boats close to the ship's side. climbed the slender masts, and, swinging toward the vessel, caught hold of the edge of a port, and clinging tooth and nail, came aboard like so many monkeys. While we waited for permission to go shore we learned that the huge, two-story building fronting us, but, alas, an eighth of a mile away. was the custom house, and the factory plant a long distance away with four brick chimneys was a tin smelter.

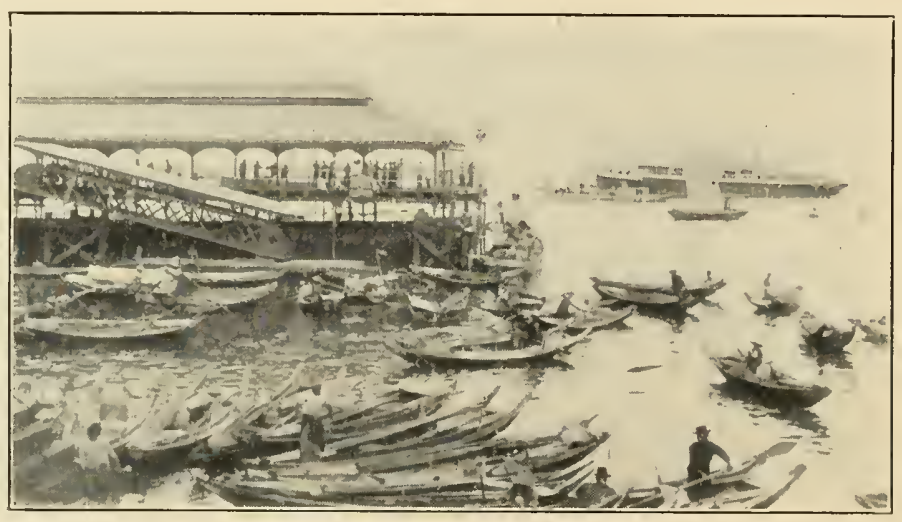

JOHNSTON'S PIER, SINGAPORE.

We were also informed that the town was not l'enang, but was Cieorgetown, I'enang being the name of the island on which the town was situaterl, and then all at once, when we were full of information, the anchor came up and we sailed away. At first we were very much disgusted, but as we circled the island and struck into the Straits of Malacca in plain sight of the low lying shores covered with sraceful cocoa-nut palms, with ranges of mountains in the distance, and as island after island appeared in sight, each willer and more beantiful than the last. We forgot our disappointment and became engrossed in the scenery. Possibly to make us more goorl naturerl, we had a magnificent Christmas pudding that night and then a nutsicale on deck, at which the first officer sang and the fortrth offiecr played, and all joined in sancs mutil it was time lo retire. 
It grew rough in the night and the pagan who pretended to look after my comfort slipped in and closed the port, which drove me on deck very early in the morning. to find the day lowery and clark, with a high wind blowing. Toward night, however, the clouds had seattered, all except a great black mass that lay over Sumatra way. As the sum dropped behind this mountain of cloud, and sent its rays through it, lighting the interior, we looked into huge golden caverns, their crimson ceilings upheld by twisted columns and arches of fantastic design, while the light shining above the cloud mass flecked the sky to its furthest horizon with wonderful combinations of gold and purple that held one breathless with awe and delight.

After passing Malacca, which showed sinply a white line close to the water's edge, so far away was it, and many islets covered with

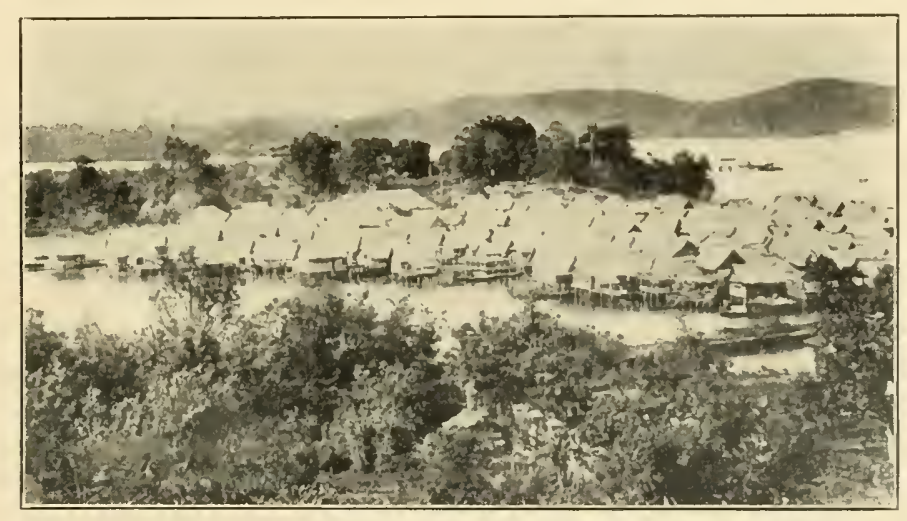

MALAY VILLAGE "PULO BRAN" SINGAPORE.

[T he huts a!l on supports, over water.]

palms, we sighted Singapore about $+0^{\circ}$ clock in the afternoon. As the tide was not right. we couldn't take the nearest channel, but were obliged to go outside of the strongly fortified islands that form natural breastworks for the fine harbor, and by putting on all steam. we were able to get up to the $P$. and O. docks just as night fell. Those of us who were going to stop in singapore went ashore at once. learing our baggage to follow. and. in a square. box-like gharri drawn by a little Finrmese stallion, we drove by the Malay fishing village, arounc? through the Kampong Glam to Raffles Hotel. said to be the hotel de hure of the East. There we had dimer and later took rickshaws and rode through the Chinese. Malay, and Japanese quarters, watching with eager eyes the strange street scenes. listening to and trying to rennember 
the grotesque calls of the street venclors, and finally seeing and hearing so much that was new and strange that it was a relief to get back to the quiet hotel and turn in on a hed that had neither top sheet nor coverlet, because in that clinate. even though the whole sicle of the room was open to the night air, no such covering is necessary. In the morn.. ing I had a new experience-a bath in Eastern fashion. for the bath roon is a bit different from what the ordinary diveller in the temperate zone expects. It is cement floored and gullied, with a luge urn in it from which one dips buckets full of water to pour over the body. In other words, one stands ontside of the tub to bathe. To get into it is out of the question.

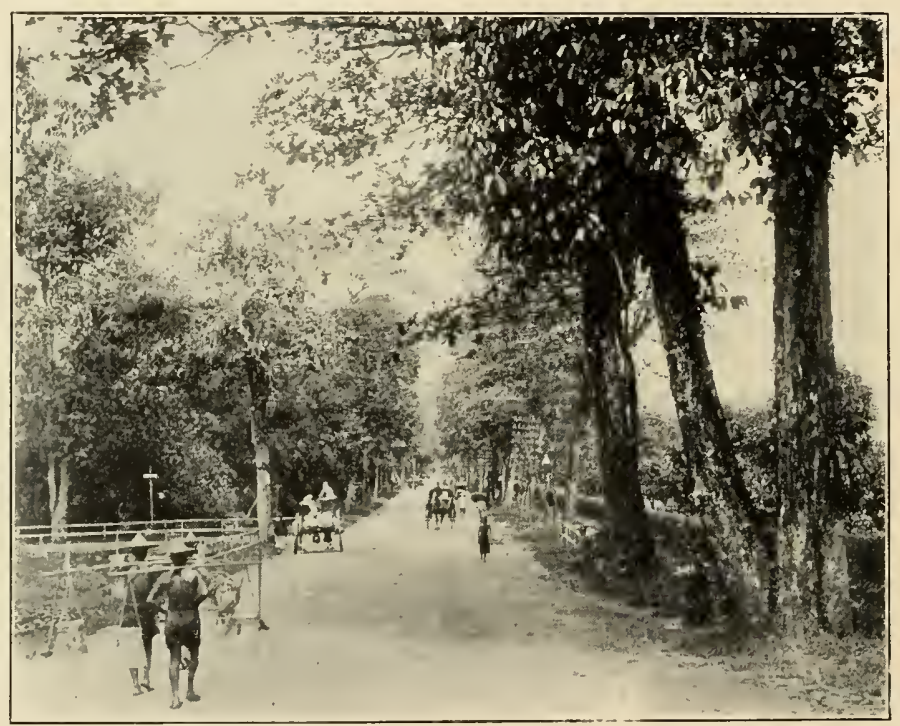

ORCHARD ROAD, SINGAPORE.

And now a word about Singapore. It was founded, so the English say, in I8I9, hy Sir Stanford Raffles. The real date was, however, I 283 when it was founded by the Malays and becane at once a general rendezvous for their pirate craft. It is 8,000 miles from England, is the seat of government for the Federated Malay. States, and is a sreat and growing business center. In the census of Igor the population of the island was 184.554. (of this, ro1.yog were Chinese, 35.000 Malays. 16,000 natives of India, and 2,760 ) whites. The island contains two hundred and seven square miles and lies rather low. the land being on an average from twenty to thirty fect above sea level. The average mean 
temperature in the shade is from $80^{\circ}$ to $85^{\circ} \mathrm{F}$. The rainfall in singapore and the Malay States is from ninety to two hundred inches. The city is under excellent control, the buildings in the business portion leing quite imposing, and the harbor, with its magnificent fortifications, most excellent. The visitor at once notes the strange mixture of races that place their impress on architecture, business, and modes of life. The naming of the streets is an example of this. For instance, there is Victoria Street and littkit Timah Road, together with ()rchard Roarl and Teluk lilangah Road, and so on.

After morning coffee, I took another ricle through the crowderl, harbaric, festering, native quarters, and harl my eyes opened to many

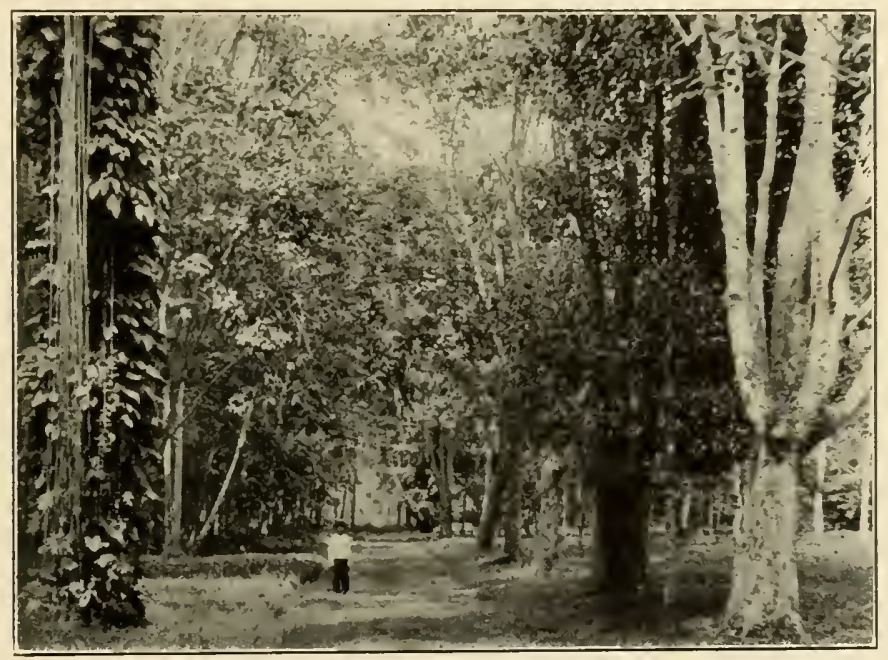

FIELD OF PARA RLBSER ("HEVE.I").

[In Singapore Botanic Gardens.]

things. The European and business parts of the city are really very fine, and, except in the heat of the day, quite comfortable. It was not the rainy season, yet heavy showers came up almost every afternoon, and although it was cooler in the evening it was still hot and clamp, and few of the hotel people showed much energy. Nor did they take any especial interest in the wants of their guests. No time tables were obtainable, nor was it possible to discover from the clerks anything about the departure of trains, the sailing of steamers, or the time when the postoffice would be open. They were not in the least discourteous, but simply weary and vacuous. 
In spite of the midday scorching sun, in which all of my spare clothing was spread to kill the mildew. I took a rickshaw and rode out over Orchard Road to the botanic gardens. I was n1ost liospitably received by Director Henry N. Ridley, F. L. S., and shown all of the various rubber and gutta trees and vines that he has so industriously collected. The Herca was naturally my first concern, and I found Mr. Ridley most willing to talk about it, as he has long advocated its very general planting, and certainly the soil is excellent and the trees respond to cultivation wonderfully. From one hundred cultivated trees on an estate in Perak, Mr. Ridley has taken nine hundred pounds of Pará rubber in one season's tapping, and from nine to twelve pounds have been taken from a number of trees in the peninsula, but planters do not always

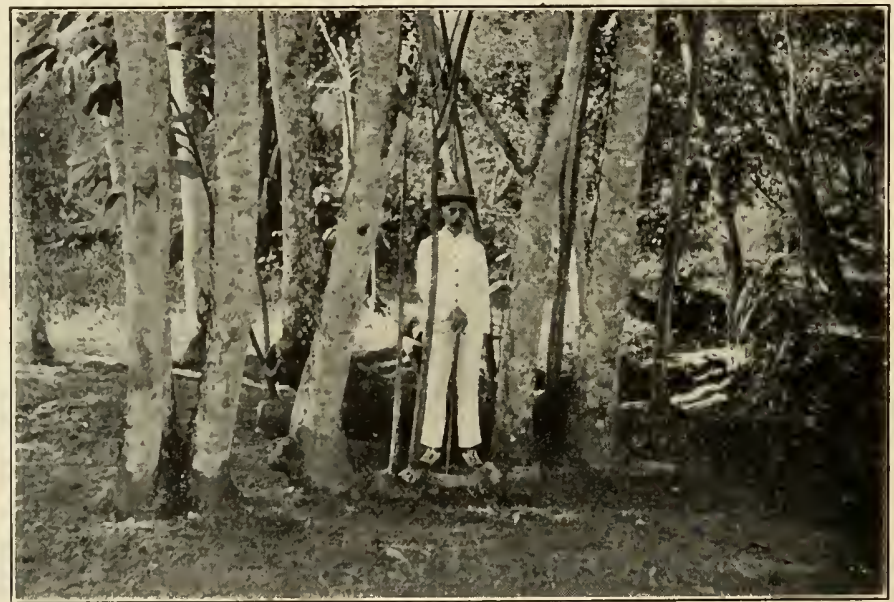

SHOOTS FROM A FALLEN HEVEA TRLNK.

[With view of Director H. N. Ridley.]

get such returus. He has also taken three pounds from a single isolated three-year old tree. The growth here is phenomenal, a tree eighteen months old sometimes standing thirty feet high, while three-year-olds often attain a height of sixty feet. I found in these gardens the Horca growing in a variety of soils, and all apparently thrifty. For example. high up on a gravelly hillside, were a half humdred trees that were eight or ten years olk, and sixteen to eighteen inches in diancter. These were planterl in partial shade. but had outdistanced all surrounding growths. The other extrene from this was a large planting where there were but six inclues of soil above water, the soil being often submerged but draining off very quickly. Here the trees grew well, but were apt to 
be blown oser because of their shallow resting. To show how tenacions of life the tree is, it is only necessary to examine the photographlo of many such trees that, blown over, took fresh root from the tops and sent up shoots that soon developer into sturdy tree trunks. I counterl seven such trunks springing from one prostrate stem, cach trumli lige (1)ough to tap, and full of later.

- Inother experiment in distance planting was a row of serenteen trees that were set six feet apart, that althougl they were only eight

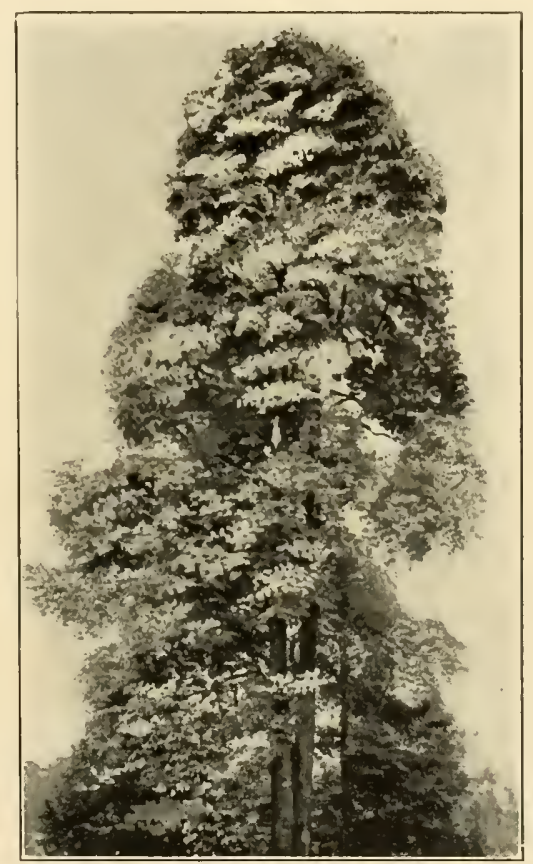

GLTTA-JELLTUNG TREE.

[Botanic Gardens. Singapore.]

years old, were two feet in diameter and showed a magnificent lea $\dot{f}$ area. These, of course, had the sum on both sides, and thus came along faster than if in partial shade. The number of Herou trees in the gardens now ready for tapping is 1.300 . I still further experiment with the Heco was the planting of the seed in specially prepared beds, in which a variety of different manures was placed. The photograph tells the whole story and would seem to point to cow dumg as the best food for young Heica. The soil in the garlens is not particularly rich, being 
of a red, gravelly character, showing traces of iron, but the moisture and the sunlight make up for what it may lack.

Next after the Her'ca I wanted most to examine the tree that produces the Gutta-jelutong, or Pontianak gum. I found that it was very conmon all through the Federated Malay States, and that the gum was rarely taken from it, the tree being regarded as useful only for the cheap clogs that the natives wear. The tree is botanically the Dycra costulata and when mature is a splendid forest creation. One in the gardens, of which I have a photograph, was certainly one huncled and fifty feet ligh, with a huge three part trunk, and a magnificent crown of leaves. We disl not tap this one, but went into the jungle, found a wild one, and tapped it after the most approved method. The late.r oozed out like clotted cream and seemed most abundant, but began to coagulate almost at once. It is said that a mature tree produces as much as one hundred pounds, by scraping the bark rather than tapping. and mixing at once with kerosene.

In the hit of jungle where we found the I'ontianak tree, there was killed only a few days before a thirty-foot python, that had not been thought a particularly undesirable neiglibor until he swallowed a couple of Mr. Ridley"s swans, which ended his career.

The Castilloa in the gardens did not seem to be in a very flourishing condition, nor did the Ceará rubber trees, although both have been carefully experimented with. The former seemed to be stunted, while the latter was apt to develop hollow stens. A further trouble with the Castilloa came about through its habit of shedding its temporary branches, which gives a nice, sheltered, tender spot for the beetles, of which they often avail themselves. There was also a most luxuriant growth of the Willughbeia firma, but it was such a tangle that it would be almost impossible to get any rubber out of it economically. Indeed, I have yet to find anyone that has experimented with the culture of a vine that is a rubber producer who has any faith at all in it. The H'illughbeia, however, when wild, produces a good grade of rubber that is known as "Borneo," and is very easily coagulated after tapping. There were also a great varicty of Gutta-percha trees, together with the Ficus and the Kickstia, to which we devoted considerable attention.

Director Rilley is a most charming companion, and as he often takes long journeys into the forests accompanied only by the wild men, his stories of adventure are very interesting. His guicles, by the way, never can understand his interest in insects or plants, except upon the hypothesis that he is after ingredients to make "gold water," a magic 
liquicl that the white man is always yearning to make and which will turn anything into gold. The type of coolie in Malaysia is, howerer, far superior to that in Ceylon. They are better formed, stronger, and far more self respecting. Nor to they call the white man "master"; to them he is "twan" (

There are many tigers in the Malay peninsula and some in the island of Singapore. In the bit of jungle where we secured the late.r of the Ciutta-jelutong there often lurked a tigress who swam over from the main land and had her nest there. As a rule they are troublesome only as they steal the Chinanen's pigs, and while there is now and then one who gets to be a man eater, it is not European meat that they seek, but the flesh of the coolies. They are rery clever and hide themselves so well that one may almost step on them in going through the jungle. Once they are discovered, however, they charge for the intruder, uttering a tremendous roar. If they are not wounded and the charge is avoided, they slip off into the jungle and are almost instantly lost to sight. There is a record of a large tigress with two cubs that terrorized twenty miles of well traveled road, killing on an average a coolie a clay for months. She was finally killed by a spring gun, but the culs escaped. They did not turn out to be man eaters. The tigers are fond also of killing the water buffalo. To do this they lunt in pairs, one cutting the creature out of the herd, while the other lies in wait, and at the right moment springs on his victim, seizes it by the neck, and, leaping high in the air, throws the whole weiglut of his body in such a way that the neck is instantly broken. Referring again to the man eaters, they kill their prey by a stroke on the neck, and in feeding eat only the coolie's legs.

The most vicious beast in Malaysia, and one that both Europeans and natives dread, is a bison, something like that of India, only larger. It is a huge animal, six feet high at the withers, short legged, and heary bodied. It lives in the forests, feeds on fruits, and usually attacks man on sight. They are very hard to kill and are the dread of the foresters. It is easily the largest ox in the world, and by far the most dangerous.

There are, of course, many snakes, and of them the cobra seems to be the best known. The Singapore cobra is a much more vicious appearing reptile than is its cousin of Ceylon, and with different habits. It is known as the black cobra and rarely bites, choosing rather to eject the poison at the eyes of its enemy, and at eight or ten feet distance it is a pretty fair shot. If the eve is not at once treated by some sort of alkali, or if the venom gets in an open wound, the results are quite 
serions. While I was at the botanic garlens. Mr. Ridley was treating the eyes of his fox terrier. who had just killed a colsa, and in the fight got his eves full of poison.

Returning from the botanic garclens, I called upon Messrs. Huttnach lirothers, to whom I had letters of introduction. They are large trarlers, sending shiploads of rattan from Singapore, and bringing great cargoes of coal from Japan. They are also agents for tin mines in Johore, and inciclentally handle much Ginta-percha. They were of the

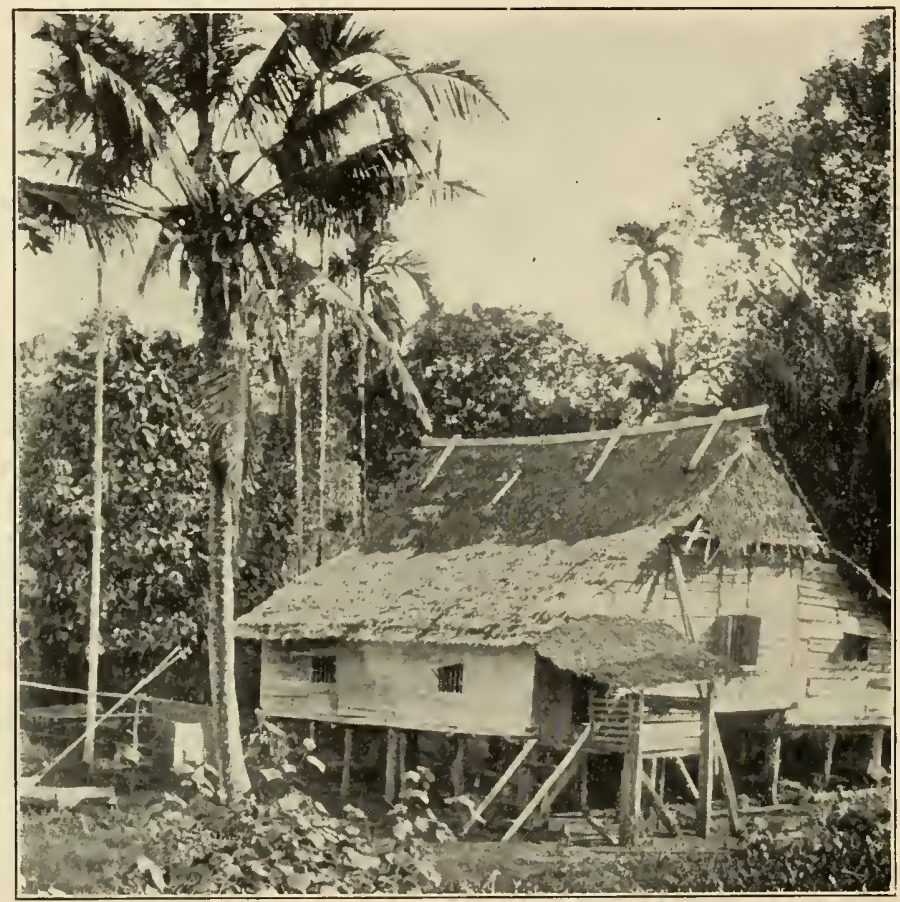

MALAY HOUSE IN JOHORE.

opinion that the Marconi system was alrearly affecting the gutta market. as there was much stock in Singapore, and according to their advices. a sreat cleal musold in England. Through their courtesy I was taken to the Chinese merchant (puarters and shown the reboiling process that prepares the gutta for the markets of Europe and America. IV first visited the offices and storchouses of the Teck Wah Liong Co.. Where we met the senior member of the firm, a very polite, intelligent Celestial who spoke good English. ( )nir interview took place in a fine anteroom furnished in Chinese fashion, with many sturcly ebony chairs set close 
to the walls, while huge lanterns hung from the ceiling. In the rear rooms were many brick tanks about $20 \times 20$ feet and five feet high, covered with cement, in which the gntta was stored moler water. The flow was tiler and piled ligh with blecks and rolls of gutta, which, to keep off oxidization, was frepuently wet down by turning a stream of water on it by means of a hose. Although they were equipped with reboiling tanks, none were then in use. so we were taken to a nearby warehouse where the work was in progress.

The Ginta-percha as the reboilers receive it comes in large crumbly cakes. These cakes are put in a tank and boiled in hot water, after

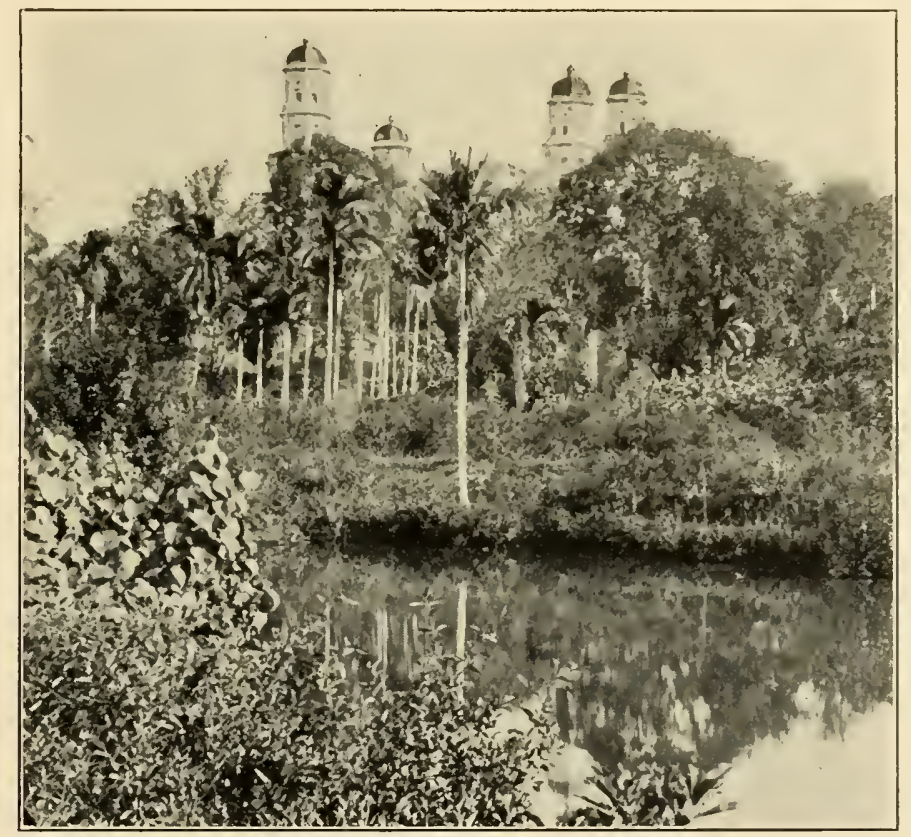

NEW MOHAMMEDAN MOSQLE, JOHORE - YIEW FROM SE.LSIDE.

Which the mass is run through a large mangle turned by two coolies and fed by a third. It is next dmmped into a tank of cold water, allowed to cool, and then stacked up to dry out. After arying it is cut into shreds by coolies who use great cleavers for the purpose, and it is again boiled, and sheeted, and cooled as before. The same process is gone through with a third time, but when the sheets come from the mangle this time the gutta is folded into neat rectangular blocks and is rearly for market. The boiling. sheeting, and cooling. toughens the 
gutta appreciably and also allows of certain admixtures that are supposed to be suited to some grades. For example, in sonle of the lower grades a modicum of Pontianak is often introduced. All the gutta that I saw was said to have cone from Borneo in small lots, though my informants told me that they received shipments occasionally from the I'hilippines.

I had heard so much of Johore and its young and athletic sultan that I had a desire to see it at close range. I was, therefore, much gratified by an invitation from the chief of the agricultural bureain there. Mr. F. H. M. Staples, to pay him a visit. I knew that I should miss the sultan, as rumor had it that he had taken $\$ 200,000$ in gold and started for Europe for a vacation from the cares of state. A brief rickshaw ride from the hotel took me to the Johore and Kranji railroad, where in the "first class waiting shed," as the sign on the wall had it, I waited for my train. When it appeared I got aboard and again waited. After a time the dusky hued master came out and rang a big dinner hell most energetically, which was the signal to start. Still we waited and waited, but finally reluctantly pulled out. The ride across the island is short and pleasant, and is through many plantations and some jungle, and terminates at a ferry where a steamer transfers the passengers to the domain of the sultan. Mr. Staples was awaiting me and was good enough to put me up at the Johore Club, and I had tiffin with him at the sultan's hotel. In the afternoon we drove out to the rubber plantation, which is about three miles from the town, and which now consists of some fifty acres of Ficus clastica quincunxed with Pará. As all the manure from the dairy farm is to be used on this plantation, the rubber should come on very rapidly. In addition to what is already planted, large clearings are being made, com being first planted with the rubber for shade. On my return I had a look at the native village, went again over to the hotel and club, where I met the postmaster general, the chief electrician, and the Datto Abul Rahmin, admired some fine pictures of the sultan, and returned to Singapore.

lefore I knew it I was facing the new year, and as New Year's day came on Fridlay, the rest of the week was taken by all as a period of rest. This suited me pliysically, for I was exceedingly languorous, but not mentally, as I longed to be up and doing. I gave up to the climate, however, and idled. Indleed, the wish to remain quiet grew on me to such an extent that had there been then more days of it 1 think I should have stayed in Singapore. My bedroom boy, Poo Kee, a short, clumky, good humored Chinaman, made everything as casy as possible 
for me. When I orelered a bottle of Apollinaris he bronght ink, and I never could enet him ont of the habit of starting the water rumuing in the bathroom and leaving me to turn it off.

During my enforeed idleness I dicl go down to the billiard room and play a few games, but more to hear the markers chant the score in Malay than for the fun of the game. To be sure I rouserl up one evening and went out to see some fifty rickshaw men try to thrash two Russian sailors who would not pay for their ricles, but it was more like a game of tag than a fight.

On New Year's morning there were sampan races in the harbor, where the native boatmen displayed surprising skill, and the spectators

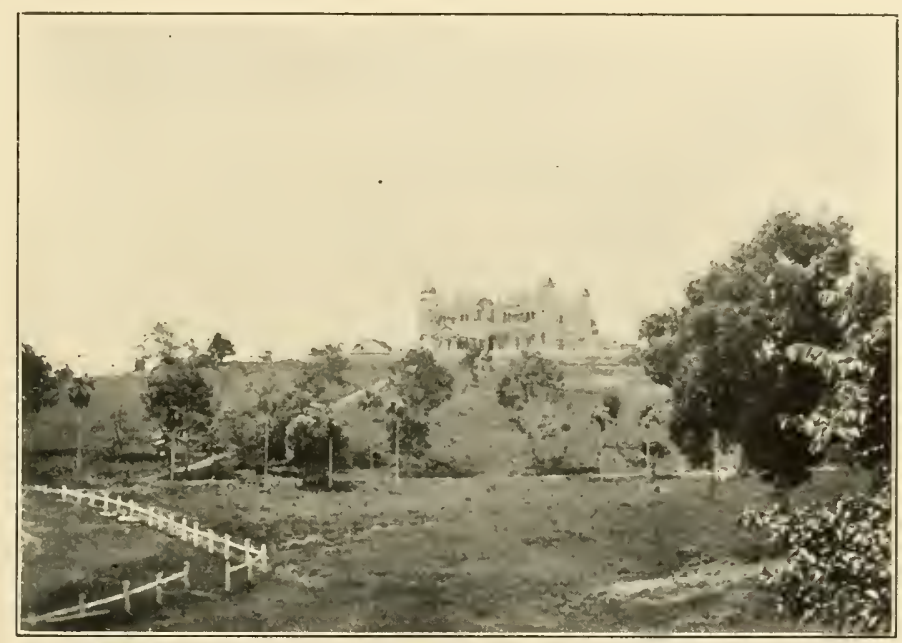

ISTANA OF THE SLLTAN OF SELANGOR.

grew wildly enthusiastic in spite of the fact that it was exceedingly hot and the glare of the sun on the water was almost mulbearable. The heary rain that came up early in the afternoon, but lasted only an hour, did not discourage the merrymakers, and as great crowds were going ont to the racetrack to see the natives compete with one another in a variety of sports, I went too. The turf around the track was sodelen with water and the track heavy, but in spite of it all there were olstacles races, treacle lipping for silver coins, rickshaw, pony. and hurdle races that were both ludicrous and interesting. As on the evening before there had been a great dimner followed by a clance at the Raffles Hotel, and at midnight "Auld Lang Syne" and "Crod Save the King" had ushered in the New Year, I could but feel that it had been heartily welcomed. 
In the meantine several warm invitations had come to me from planters up in the "States" to visit them and have a look at their rubber. I therefore decicled to go up to Selangor, where as far as I could judge. I was likely to see rubber that would typify what that part of the world could produce. Not that the oldest Herea was there, indeed some one told me. I do not remember whom, that the largest and oldest Heaca trees in the Federated Malay States were destroyed by mistake some years before. It seems that a former official ordered some Dyak ser-

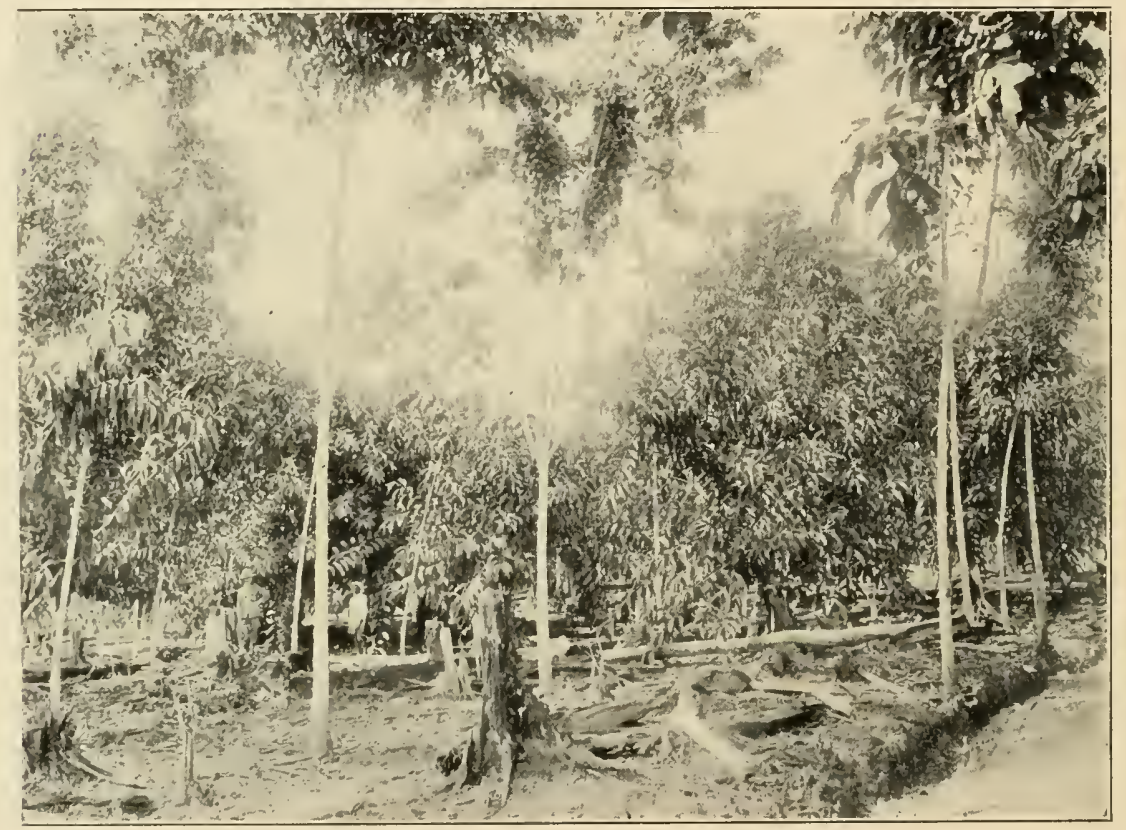

VIEW () THE PLANTATION (3F THE SELANGOR RUPBER CO., FEDERATED MALAY STATES. ["Hevea and "Ficus" interplanted.]

vants to tap the trees and they, supposing that the flow of later would be immediate and abmulant, as it is with the Ficus, and funding the case the reverse, reported that the trees were baren. They were, therefore. cut inwil, much to the subsequent regret of all.

The boat that was to take me to Selangor is known as the Sappho. and in order to get aboard of her you order a gharri to be at the hotel at three ochek in the afternom and the man will come at one and try to charese you for the two hours wait. He doesn't really expect to get the extra pals, homerer, and will respect yon more if you dont wive 
it to bim. He leaves yon at Jolnssonis pier at about 3.15. where the coolie who takes your lugrage in charge informs gou that the launch to the Sapplo, advertised to leare at $3 \cdot 30$, has gone. It is, therefore, your duty to engage a sampan, and get its owner to put you aboard. This is really more fun than it is to go in the launch, provided it is not raining. All this I dicl. ()nce aboard, I found that the Suppho was a steamer of three hundred and twenty-nine net tons, and, according to the written statement of some dock official, had sufficient rice, fuel, and water for the voyage. I was, therefore, content. I had a very comfortable stateroom and soon made the acquaintance of two young English mining engineers who had come down to Singapore for the holiday's. were going to get oft at Malacca and then ride fifty miles on bicycles. mostly up-lill, to their station. 


\section{SHTH LETTER-CONCLLSION}

Rubber Plantations at Klang, in Selangor-Mr. Balley and His WorkDistance of Planting-Age at IVinch Hevea Trees Yield-The Labor Qlestion-Mr. Carey's Planting-The Chinese as Rubber Planters-The Selangor Rubber Co.-Return to Singapore and Departuge for Hong Kong.

$\mathrm{D}$

LRING the night spent on the Sappho, on the trip from Singapore to Selangor. we passed through a succession of heavy showers. but the sea was smooth and it was cool enough to be fairly connfortable. The meals aboard the boat were also good, and the native servants as intelligent as it paic them to be. At eight the next morning

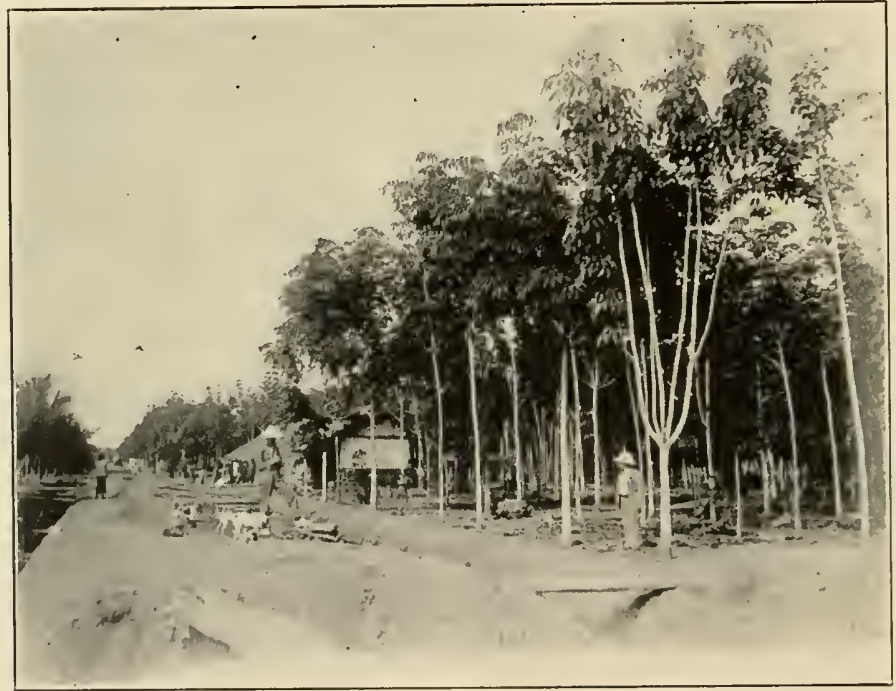

FUUR YE.IR OLI) "IIEVE.l," KLANANG ESTATE.

we stopped at Port 1)ickson, where there is a good harbor. with an iron pier and a few bungalows and native houses set clown in the jungle. Ifter discharging freight we left, following the coast about three niles ont. The land was low, wooded down to the water's edge with an occasional break where a river discharged its muddy flood into the clear water of the Straits.

In due time I reached Port Swettenhan,, where a short railroad journey took me to Klang. The station master then told me that I could 
safely trust the rickshaw man to take me to $M r$. W. W. Bailey's bungalow. where I had been invited to make my headquarters. He evidently knew the name, for he grinned, said "Bailee," and started off. Far ont into the country he took me, perspiring profusely, but keeping steadily at it. On the way we passed considerable plantations of Hez'er, which I exanined with interest. Finally he stopped at a gateway and pointed out a hillside bungalow and again said "Bailee" and intinated that he was ready to be paid. I dicl not quite share his conficlence, however, and insisted that he accompany me up to the honse. which with some reluctance he dicl. And it was lucky that I did so, for it soon dereloped that this was the bungalow of the plantation superintendent, who was. absent, the house being in charge of the native servants. Not speaking

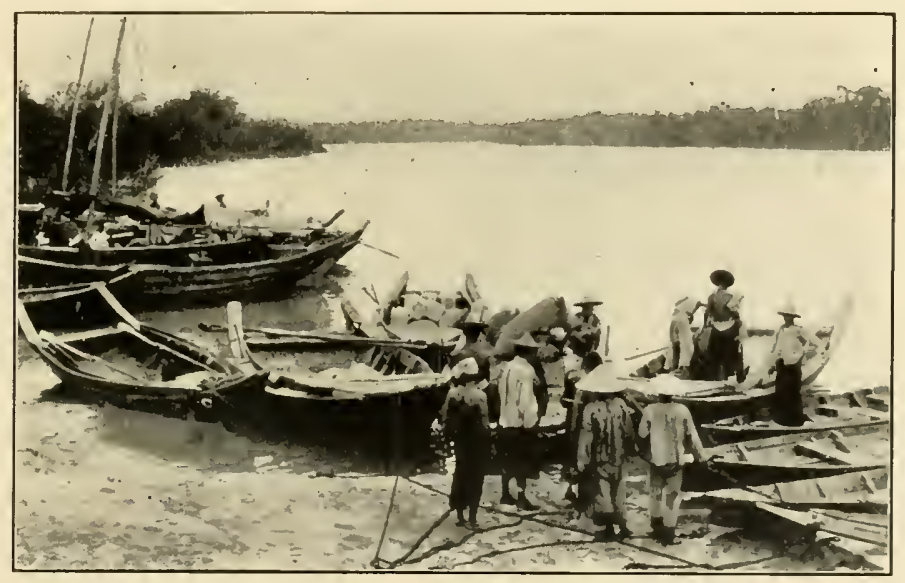

A RIVER VIEW FROM KLANG.

much Malay and they knowing no English, it was a bit difficult for me to make them understand what I wanted. but finally one of them monnted a bicycle and, inviting us to follow, led us back to Klang. and up to the real Bailey bungalow. The house was most beautifully situated on a slight eninence with beantiful palns, foliage plants, and flowers in its gardens, and a view in the distance of the lofty istana of Selangor's sultan.

I was at once cordially welconed by Mr. Bailey and his beautiful wife, and entertained most delightfully. The next morning we drove over the road that I had traveled twice the day before. and went thoroughly over both Lowlands and Higliands estates. After stopping at the bungalow of the superintendent, from which we hacl a fine view of 
acres of Herea, we drove by the coffee mill, and the coolie lines to the extreme end of Lowlands. where the very last planting had been done. This was in alluvial soil divided 11p into parallelograms by drains that were fonr to five feet wille and from three to six feet deep. The soil was wonderfully rich and was not planted with Heica seeds but three foot stumps, as the seeds and the tender shoots have so many animal and insect enemies that stumping is far more successful. These stumps are nursery plants cut back into the brown, set ont carefully and never shaderl. Not only is the top cut back, but the tap root is shortenerl a bit to prevent doubling, and the laterals are also trimmed a little.

This planting is done in any month of the year when the rains are on. In preparing, the ground holes are dug fifteen to eighteen inches

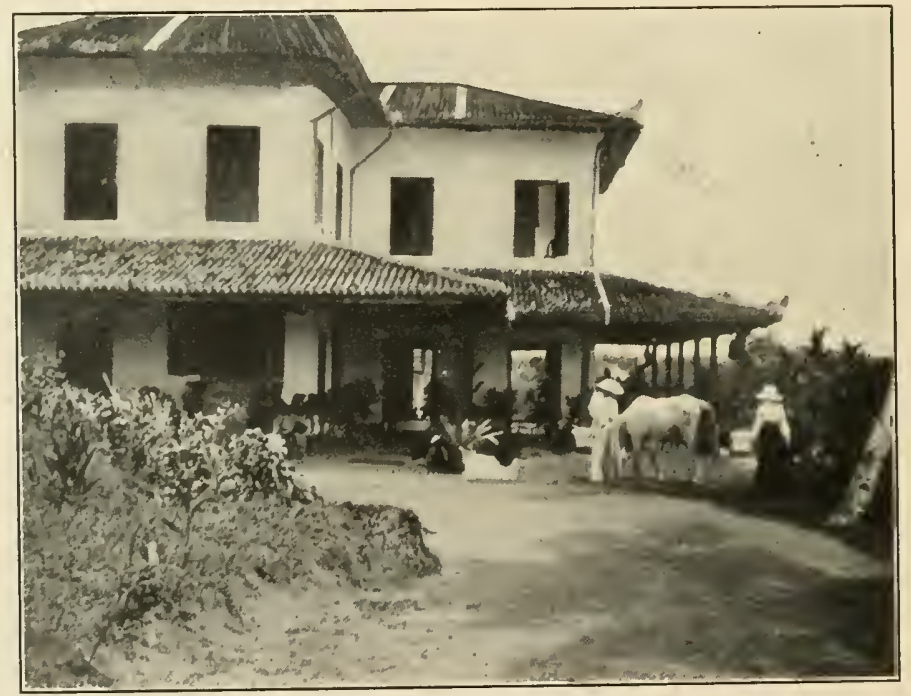

MR. BAILEY'S BUNGALUW, KLANG.

in diameter and about the same number of inches deep. the hole being left open for two weeks, after which a little of the surface soil is scraped in. Then the plant is set and carefully covered in. The trees that are rearly for tapping are selected. not by their age but from their size. For a general rule any Heica that is thirty inches in circumference, three feet from the ground, is large enough to produce rubber. In a plantation in a good location in this part of the world, the trees mature about as follows: At the end of the fifth year about 25 per cent. will be large enough to tap: at the sixth year there will be 50 per cent.. and at the seventh all of them should be big enough. 
Speaking again of the dratinage system at Lowlands, it was matrelously complete, all of the channels learling into the great anrieultural drain that ran through the midclle of the plantation, and which, I believe, wats a grovernment enterprise.

In examining the plantation we walked over geod paths ly the side wf the drains, crossing them on tree trunk bridges, and ended by driving over two very goos roads that led to the heart of the planting. The olclest rubber on Iowlands was some five hundrerl acres of fire-gear

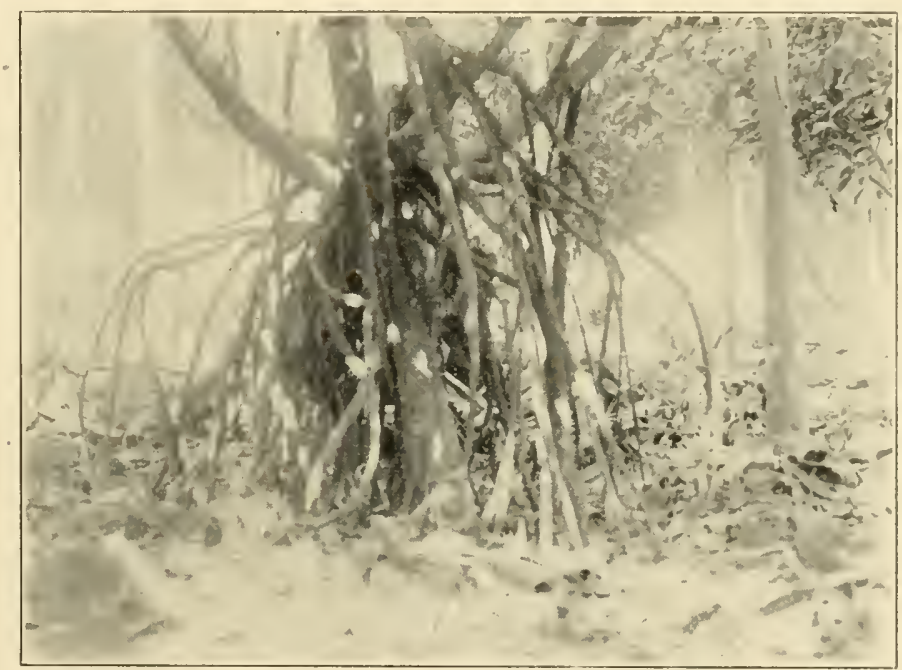

FOUR YEAR OLD PLANTED "FICLS."

IOn the Lowlands and Highlands estate. Showing the Aerial Roots as thrown down at this age. Heica trees in the background.]

old trees, numbering 52,000. These had been later interplanted with another 52.000 of varying ages. There were also one hundred and twenty acres of two-year old trees, 18,000 in number. The largest five-year olds that I saw were twenty-seven inches in circumference, three feet from the gromnd, and were in a lot that was planted $20 \times 20$ feet. Spealing of distances observed in planting. Mr. Pailey had tried many experiments. He had plots $14 \times 14$. I $4 \times 28$. I $4 \times 42,14 \times 20$, and $24 \times 21$ feet. The latter plantings were almost all interplanted later with Ficus slastica. There was also considerable coffee in with the rubber, and as it happened to he of an especially fune quality. at that time it was paying all of the expenses of the planting and care of the rubber. 
The laborers were a mixed lot, being Tamil, Chinese, and Javanese coolies. The Tamils are rather hard to get but are fairly good laborers: the Chinese coolies are good rough laborers but are not the equal of the Javanese. As there is a glut of labor in Java there is a likelihood that the planters in the Malay states will be able to get many of them, and as they all speak Malay and are content with thirty-five to forty cents. Mexican, a day, and find themselves, they are much songht after. Besides they would far rather work for an Englishman than a Dutchman.

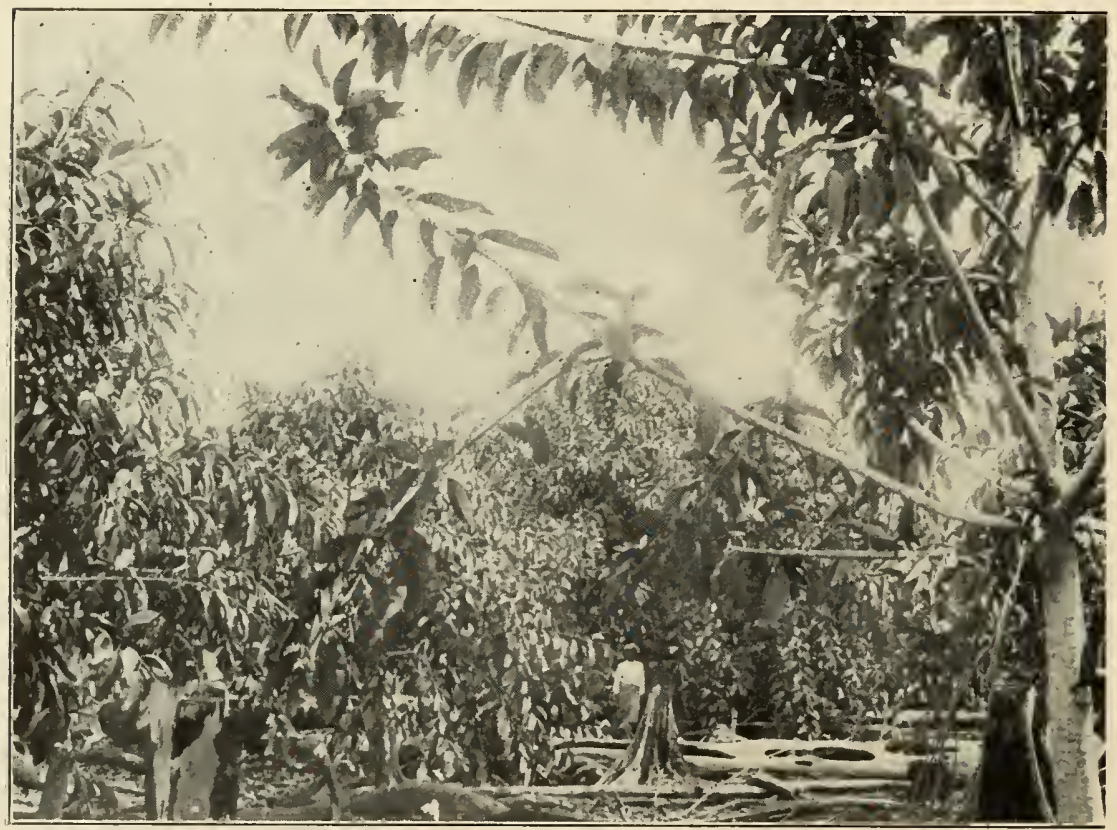

RUBBER PLANTATION VIEW IN SELANGOR, FEDERATED MLALAY ST.ITES. [Four year old "Ficus"-Selangor Rubber Cu.]

After visiting Highlands estate and looking over the coffee mill, Mr. Pailey took me for a drive ont in the outskirts of Klang, that I miglut see the small plantings of the Chinese. These were of no especial moment, being chicfly coffee gardens grown up with grass, with a few Ficus clastica or Herea trees put in at haphazard. One Chinanan, Cong Lamb, however, had abont twenty acres of coffee and Herea planted $15 \times$ I 5 feet, the trees looking about five years old and quite well grown.

But the plantations owned by Chinamen and run by Europeans are another matter: for example, the Kong latik estate, which is managed 
by Mr. L. L. Carey. Here are three hundred acres containing some 60,000 trees that average three rears of age. Nlost of this rubber is planted $20 \times 10$ feet, although there is some $10 \times 10$ and $15 \times 15$. () ne advantage of the $10 \times 10$ planting was that almost no weelling was necessary, the ground being alssolutely free from all vegetation. While going over this plantation $\mathbf{~} 1 \mathrm{r}$. Carey and I experimented with a twohandled tapping knife, an invention of his, which certainly dis rery effective work.

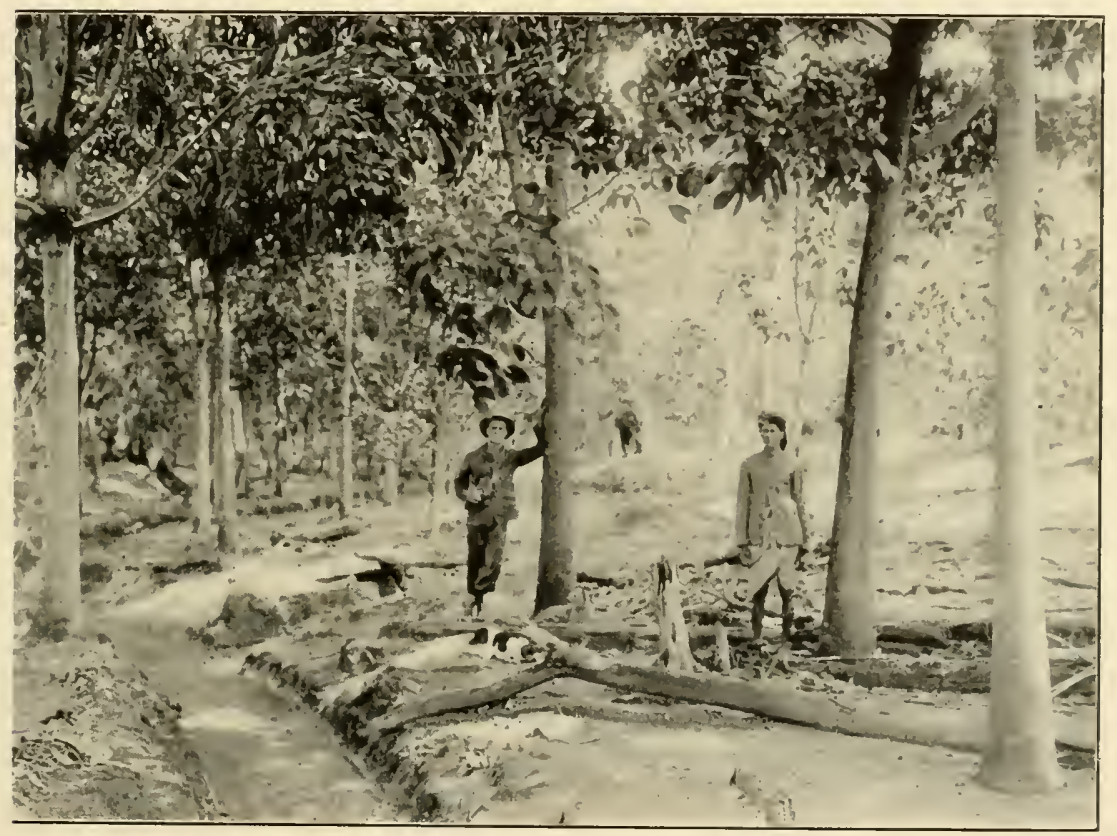

RLBHER HLANTATION WEW IN SELANGOR, FEDERATED MALAY STATES.

[Five year old "Hevea"-Pataling Estate.]

Next to the estate of which Mr. Carey has charge is the liatu L njor plantation owned by a wealthy Chinaman, Loke lew, on which there are some 17.000 four and one-half year Hereas which looked first rate.

The land in Selangor belongs to the state and is acquired ly the payment of two dollars. Nexican, an acre cash, and one dollar an acre annual rental in perpetuity: twenty-fice per cent. of the land must be under cultivation within five years, or it reverts to the government. At the same time the powers that be are very lenient and disposed to help all honest effort by granting time extensions. There is also a two and one- 
half per cent, ad zalorem export duty on such products as rubber that is a part of the land grant.

That evening many friends of Mr. Bailey's dropped in and dined and later visited the Klang Club, where I met a score or more of young Englishmen who were connected either with the govermment or with the plantations in the neighborhood.

The next morning my host took me by rail to Batu Tiga, where is another big rubber plantation in which he is interested-the Selangor Rubber Co., or, in the native. Sungei Rengam. We put in three hours

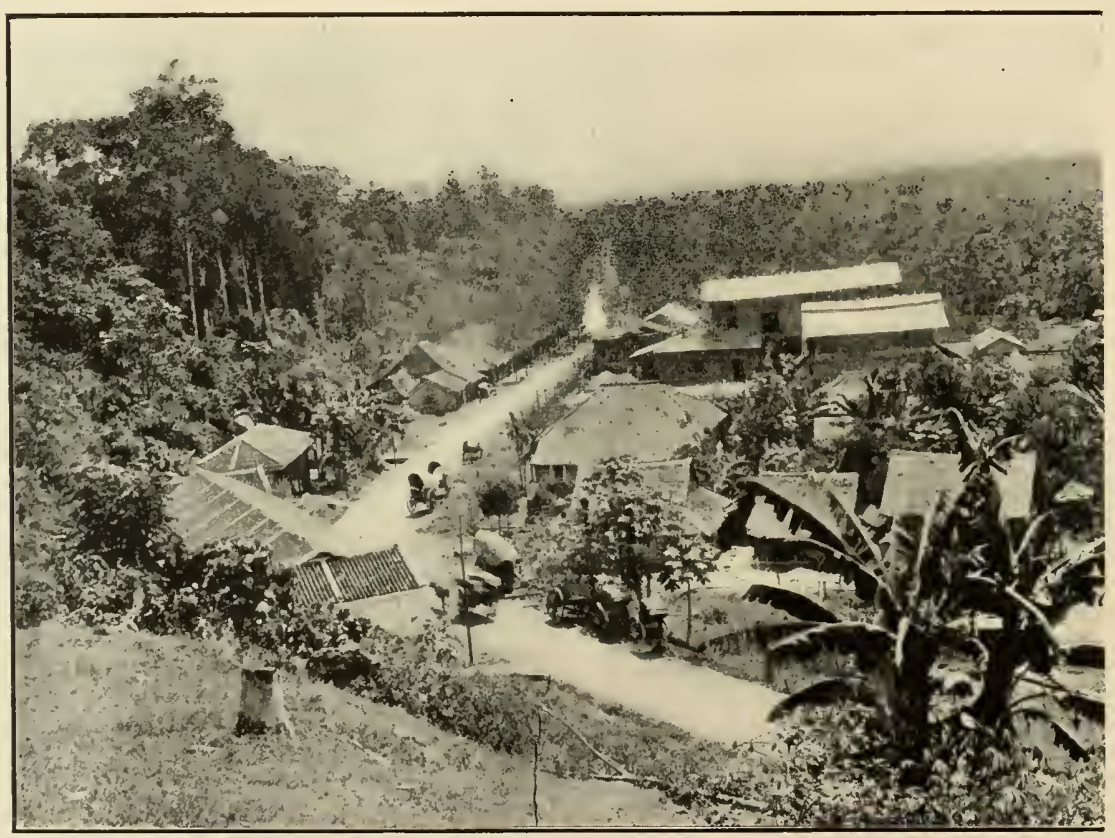

RUBBER PLANTATION VIEW IN SELANGOR, FEDERATED MAIAIY STATES.

[Panoramic view of the Highlands and Lowlands Estate.]

of hard tramping over this estate, and got very hot and damp. But it was well worth while.

The plantation is seven miles from Klang. on the railroad that joins Klang with Kula Lumpur. There is also a fine government road soon to go through this estate. 1 t eonsists of 5, 150 acres, of which 1,150 are alreaty opened and in rubber. To this will be adted three hundred acres this year, the trees being planted about two hundred to the acre. The soil is a rich alluvial, slightly rolling. and is cut hy huge drains that 
leat into the Klang and the Danansara River. The oldest planting was marle in Mar, isy8, and was $2.4 \times 36$ feet, this planting being quincunxerl in the latter part of the same year and in October, Igoo, was still further interplanted. The last planting, however, is so thoroughly shaded by the earlier that it is doubtful if it amounts to anything. The trees in the

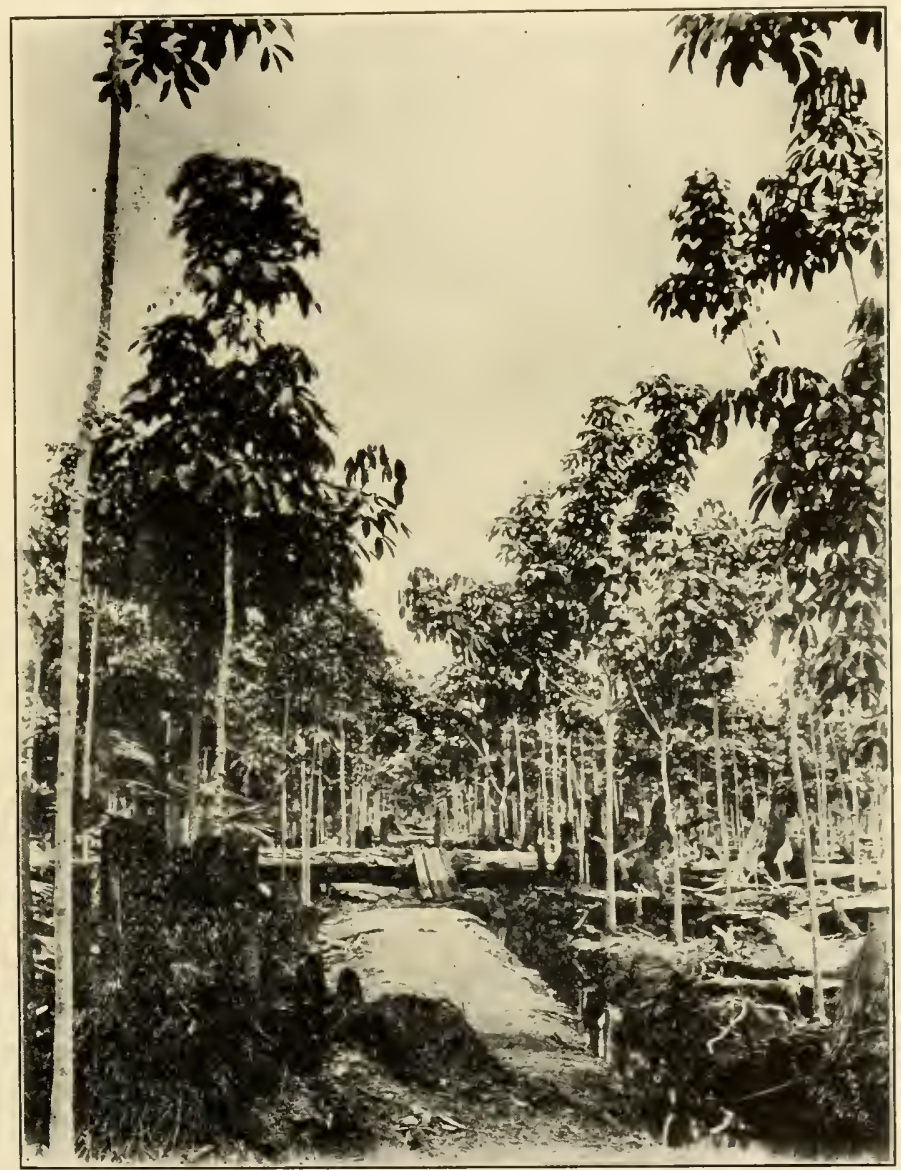

"HEVEI" ON THE V.ILL.MMBOSA ESTATE, KLANG.

first planting average $28 \frac{1}{2}$ inches in circumference, three feet from the ground. the largest being forty-seven and $52 \frac{1}{2}$ inches in circumference. Of the plantings already mentioned, there were ninety acres $2+\times 3^{6}$ feet, and forty-five acres I + I + . These latter showed an average of $29 \frac{1}{2}$ inches circumference at the base, and nineteen inches five feet from 
the ground. In 1899 there were thirty acres planted $12 \times 12$ and ninety acres I 4 If. The former measured when $I$ was there, on an average. twenty-six inches at the base and sixteen inches five feet from the ground. In Igoo there were two hundred and eighty-five acres put into Pará and forty-seven acres in "rambong" or Ficus clastica. There are also various other plantings of Pará and Ficus, alternating, of Pará and

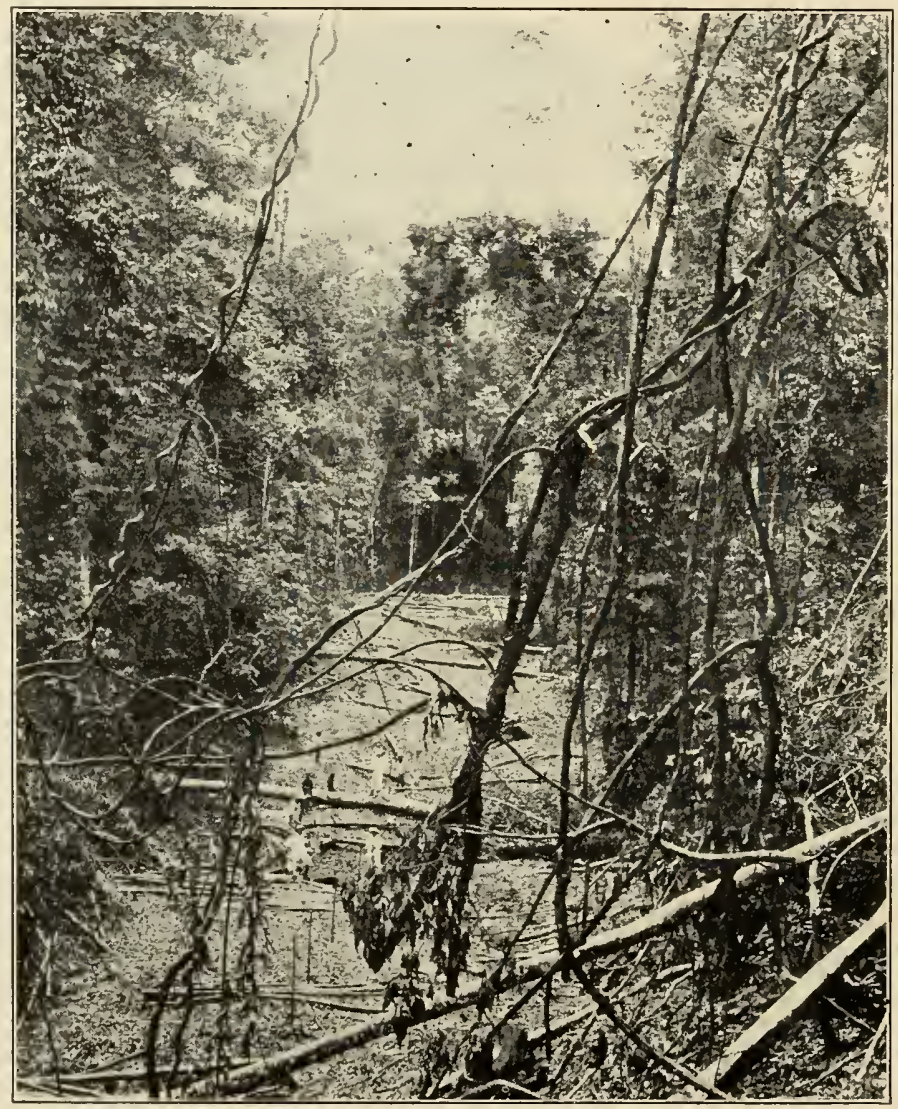

CUTTING A ROAD THROUGH JUNGIE.

coffee, and of Ficus alone. The Ficus, when alternated with Pará, seems to do wonderfully well, as does also the Pará.

The greatest care is taken of this plantation, the whole area being weerled by hand until the shade becomes so dense that no weeds grow, all of the aërial roots of the Ficus being cut away except those that 
will develop into goorl straight trunks, and the keenest sort of wateli being kept for white ants, which are always to be foumd in the new lankl. As tapping will legegin the next year, a rubber curing house $20 \times 60$ feet has been built, and all preparations are being made for turning out the best quality of rubber. All of the trees seem to produce late. abunclantly, although there was a wicle difference in the appearance of the bark, some being quite white, while others showerl a distinct shate of red. There were a variety of theories as to the canse of this, but the real reason was not apparent.

After the examination of the Selangor estate, and a very pleasant visit with the manager, at his hachelor bungalow, where, by the way, he presented me with a cane made of polished sections of a great variety of hard woods indigenots to that conntry, we again took train and started for the I'ataling estate. The roarl ran for some miles through the densest sort of jungle, the land on one sicle for some six miles being owned by the Selangor conpany. When we reached Pataling we found that the superintendent, Mr. Rendle, was away, as was also his wife. His assistant, Mr. Smith, was there, however, and he urged us to come up to the hungalow, which was prettily located on an eninence overlooking the plantation, and ordered the Malay servant to prepare for 11s "mukan," in other words, food. While we ate, it rained very heavily. but soon after cleared up and we were so sure that the storm was over for the day that we allowed a black boy to take onr mackintoshes clown to the station while we examined the rubber. The soil here seemerl a trifle hard and was more hilly than that which I had before examined. but the rubber looked well. After examining that on the hillsicles we went down to a lower level and were just heginning to take measurements when the rain came down in torrents. We each selected a big tree, under which we stood for a while, but ere long even that was no protection, so we started for the railway station. We were now drencherl to the skin and the walking was very bad. We, however, caught our train, and in clue time arrived in Klang. where, after a change of clothing and a substantial dinner, we felt as well as ever.

I had hoped to have time to run down to Port Dickson and visit Mr. I. R. Wickwar, who has a fine plantation of Herea, but I found my time wotld not admit of it. Nor dicl I visit the Pears plantation in Muar, as the owner, to whom I had letters, was absent in England.

Speaking of close planting and hand weeding. I could not but be struck with the fear that the planters have of fire. Mr. Bailey, who at one time had charge of a large plantation in Johore, told me that 
the fire once got into some thousands of acres of his sago, and although he had five hundred men of his own and nine hundred lent him by the sultan, they were weeks in getting it under. He had, by the way. some humdreds of acres of Ceará rubber which were also destroyed.

There is little Castilloa planted in Selangor. I saw a little on Lowlands. which bled freely, but the planters do not care for it, as they believe that either the Herea or the Ficus is superior. The latter tree is or course a native of this land, and grows to great size. There are

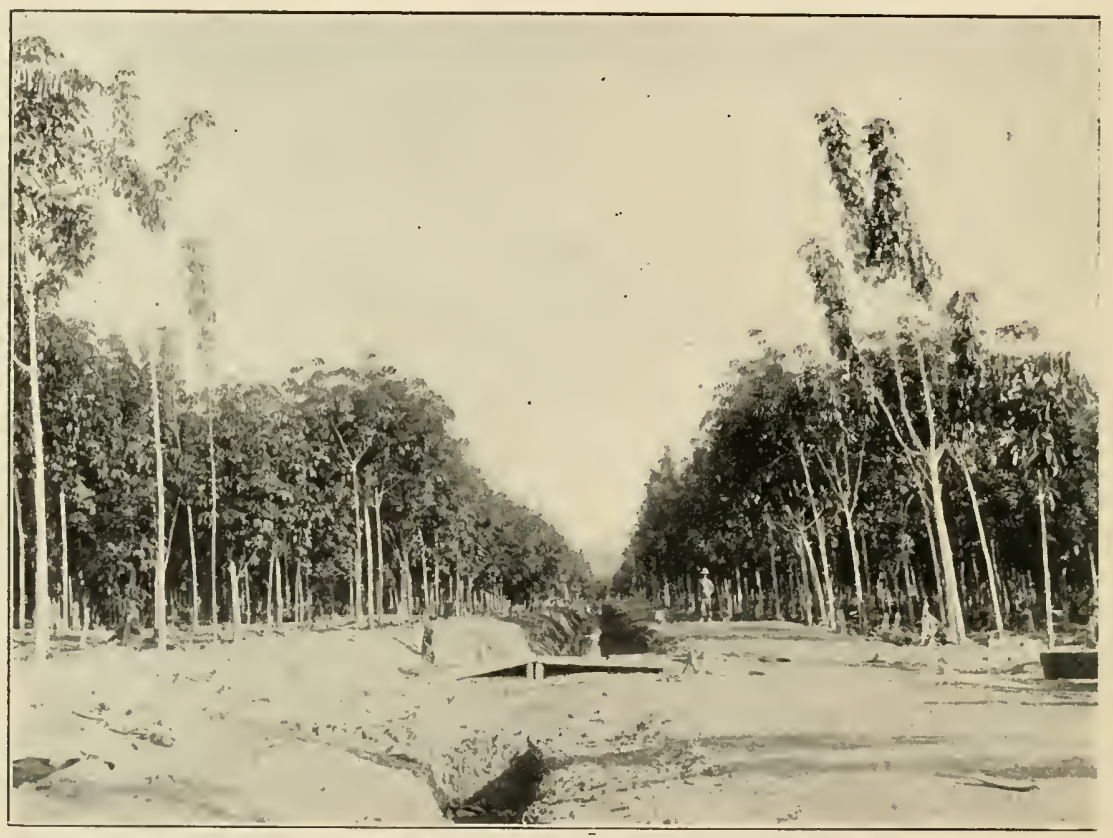

VIEI ON THE PLANTATION OF THE SEL.INGOR RUBPER CO., FEDER.ITED MALAY ST.ITES. ["Hevea" planted April,19co.]

reports of as much as one hundred pounds being taken from a single tree. Ten-year-old trees are saicl to produce from twelve to fifteen pounds.

The time came all too soon for me to say goodloye to the Baileys. whose gencrous hospitality I shall always remember, and the following forenoon saw me in a sampan headed for the Sapplo, which lay far out in the river. I got ahoard finally, and was greeted by Captain Foster like a long lost friend. The voyage back to singapore was uneventful, the sea being perfectly smooth, and the temperature bearable. 
Towards evening we came in sight of Malacea, but, much to my regret, diel not get a chance to go ashore. In fact, our captain being in a hurry, we did not even anchor, but hove to in the open ruarlstead and there received the agent, the health officers, port warden, and a few passengers. Here at Malacea is quite a large plantation of Heace owned by a Chinaman. who speaks good English and who is the proud possessor of some 300,000 rubber trees. I wanterl miglitily to have a look at it. but time did not permit.

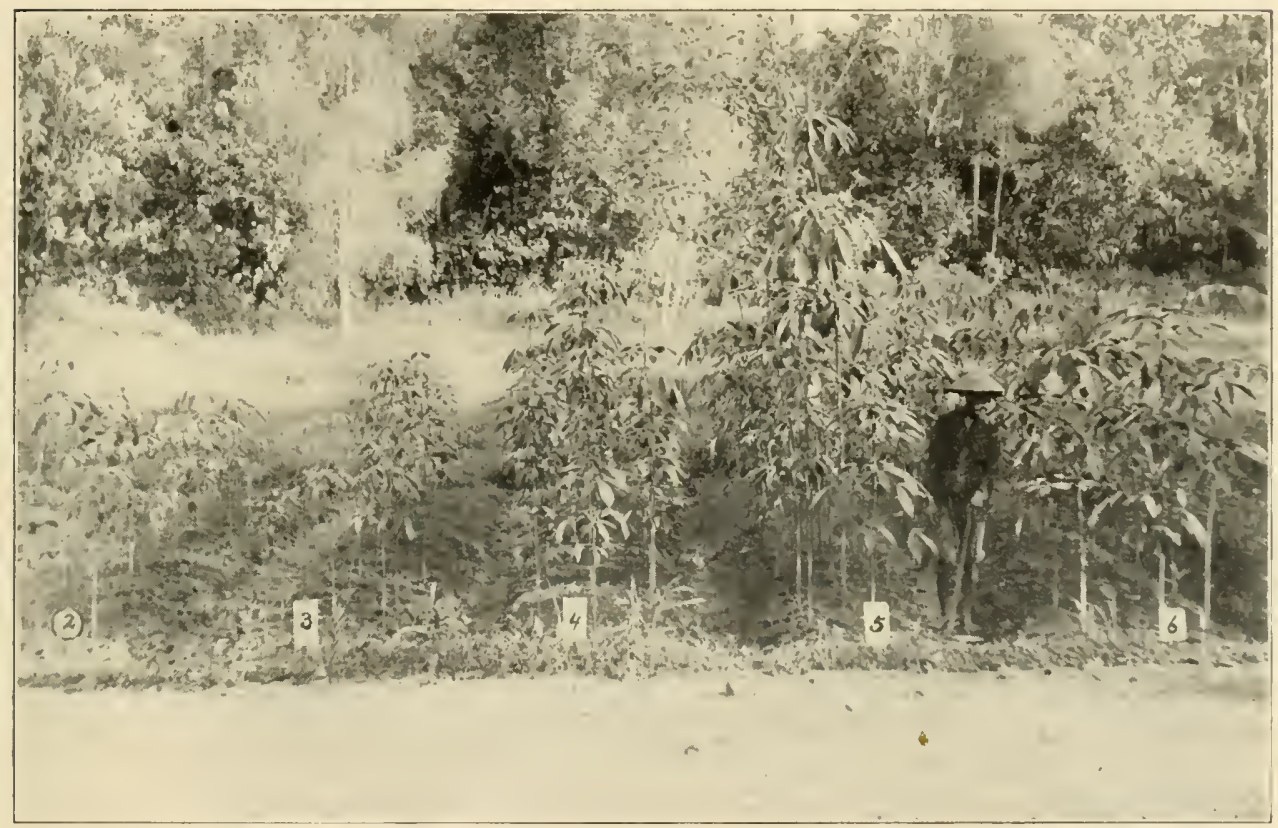

VOLNG "HEVE. "SEEDLINGS IN BEDS, IN MANLRE TEST.

[No. 2.] Poudrette. [No. 3.] Mixed Lime and Soil. [No. 4.] Burnt Earth and Leares. [No. 5.] Cow Dung. [No. 6.] Burnt Earth.

Again in Singapore I called upon Mr. Mlurray, a partner of Mr. Failey's, who had in the beginning smoothed my way appreciably, had tiffin with him, at the Singapore Club, and then hurried to get my passage arranged for on the Malta to Hong Kong. Hy the way. I took from Mr. Murray two bottles of oil made from the nuts of the Herea. which were packed as carefully as possible and which were all right until the strenuous baggage smashers of the L'nited States got hold of my luggage-and then the bottles broke. 
I was also fortunate enough to have the time for another ricksthaw ride over Orchard Road to the Botanic Gardens. Here I found that Director Ridley's right hand man, Mr. De Alweis, had made a set of photograpls for me that embraced the whole of their varied growths of India-rubber and Gutta-percha trees. One of the most striking of these was the photograph of the Hea'ca seed beds, in which the effect of various manures was shown. The experiments covered the use of poudrette. mixed lime and soil, burnt earth and leaves, cow dung, and burnt carth. As may be seen in the illustration on this page, the rubber trees planted with cow dung far surpassed all the others in height and sturdy growth.

The next day I said farewell to Singapore and was well on my way to China, Japan, the Sandwich Islands, San Francisco, and home; that in brief is the finish of ny visit to the rubber plantations in the Far East.

On nyy way home I met those who were deeply interested in rubber culture, as a future development of the rich lands in French Indo China. Pritish North Porneo, and Sumatra-in fact, wherever there is the conjunction of proper soil, clinate, and cheap labor. Even the Japanese are preparing to plant rubber in Formosa. In the I'hilippines there is little present interest, as the shutting out of Chinese ancl Javanese labor makes the installation and care of a plantation far too costly to be remunerative. 
RUBBER PLANTING ON THE ISTHMUS OF TEHUANTEPEC 



\section{FIRST LETTER.}

Foreword-From NeW York to the Borner-Oner the Alkill PlainsNative Foon-Mexican Opals-The Nochistongo Canal-. Irriral at Mexico City-Journey South of the Capitul-Amextures it Achothl-ON Horseback Oyer forest Trails-The Demarest and Newmark Estates-Arriyal at "LA Buena Ventura."

$M^{\prime}$

journey to the Tierra Caliente, or "hot country," in Mexico, was taken with the sole olject of seeing for myself cultivated rubber planted by both individuals and stock companies. I selected typical plantations as far as 1 conlel, most of them in the state of Vera Cruz, on the Isthmus of Teluantepec. The states of Tabasco and much of Oaxaca and Chiapas I was forced to leave ont of my

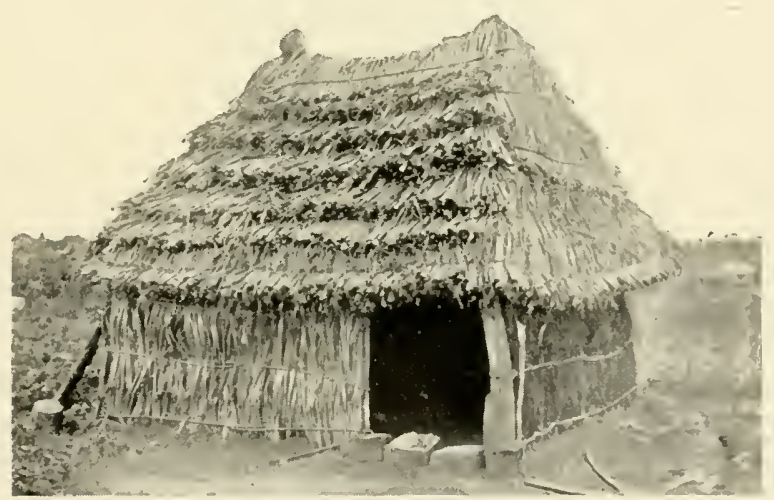

NATIYE HUT IN THE STATE OF VERA CRLZZ.

itinerary, although they too have large and successful plantings. which I hope to visit later. I left New York quietly and alone, paicl all my own expenses for the whole trip, and carefully avoided exploiting either myself or those who had shares or land to market. This statement seems necessary, because, since my return. I have been asked in all serionsness whether this or that company had me "uncler its wing," to use later for advertising purposes. I wish also to add a word of thanks for the courtesy, the generous hospitality, and the frank, helpful cordiality extended to me by the planters whom it was my good fortune to visit. May I add that, of the conclusions clrawn from my visit-mbile they 
prove to whe that certain procedure in clearing, planting, care, etc., is vital in the localities under consideration-it does not follow that, given a different locality, soil, and climatic conditions, other methods might not prove necessary.

In spite of an innate belief in my own preparedness for the Mexican pilgrimage, when ready to start I lost no time in consulting persons who had gone before as to material equipment for the joumey. The advice received solved itself into the purchase of a broad-brimmed soft hat,

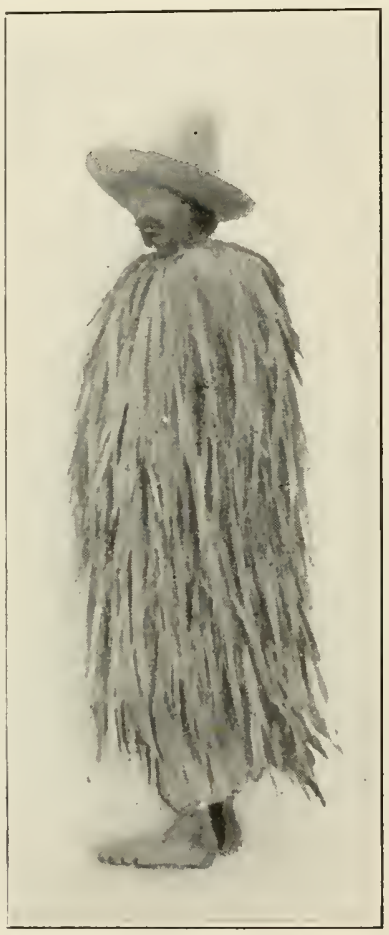

CANE FIBER RAINCO.AT

negligé shirts, light flannel underwear, a "navy bag" (a dress suit case on horseback, being a source of worry and a constant temptation to landing on one's hearl), and a pair of long-legged moosehide "snake boots." To this was added later a Colt's revolver and holster, to be worn in the unsettled country south of the City of Mexico: a rubber poncho coat that looker like a long, tan colored nightshirt, a linen suit, and for medicines. a box of cascarets, a bottle of chloranodyne, and a pint of two grain 
quinine pills. Had 1 appreciated the pertinacity of the Mexican flea, I should have added a bower and a ponnel or two of 1)almatian poweler.

It was snowing when onr train left Jersey City, starting for the southland. Nor did winter really forsake us until we were well into the Indian Territury. Is a matter of fact. I lo not think I fully realized that I was on my way to the land of the Castilloa, mntil I awoke one morning and saw the dwarf cactus that srew ly the side of the track, and furtler on, at San Antonio. Texas, hegan to note the picturesque Mexican

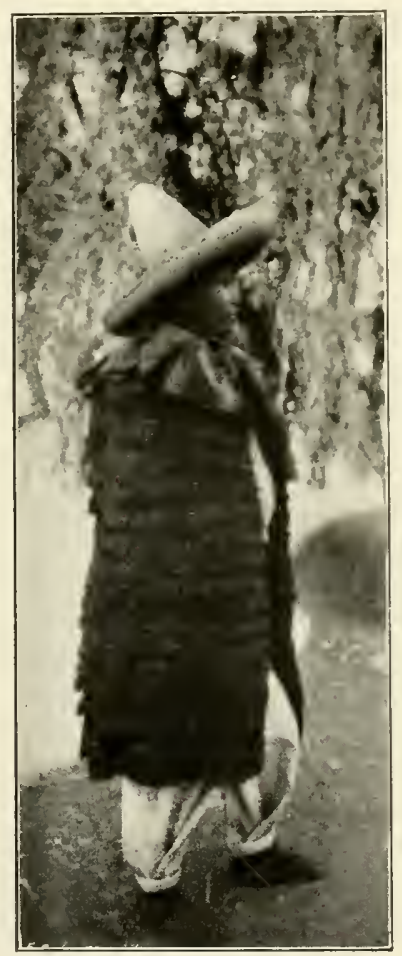

COCOA FIBER RAINCOAT.

costumes and the subtle influence in architecture, climate, and soil, that proclaimed our nearness to a land of strange peoples, customs, and language. Finally we crossed the Rio Grande, drew up on Mexican soil, had our baggage exanined by dark complexioned officials who were polite beyond belief, clunged our money, getting two dollars and fiftyeight cents for each dollar of Lncle Sam's currency, and were at length in the land of the Aztecs. 


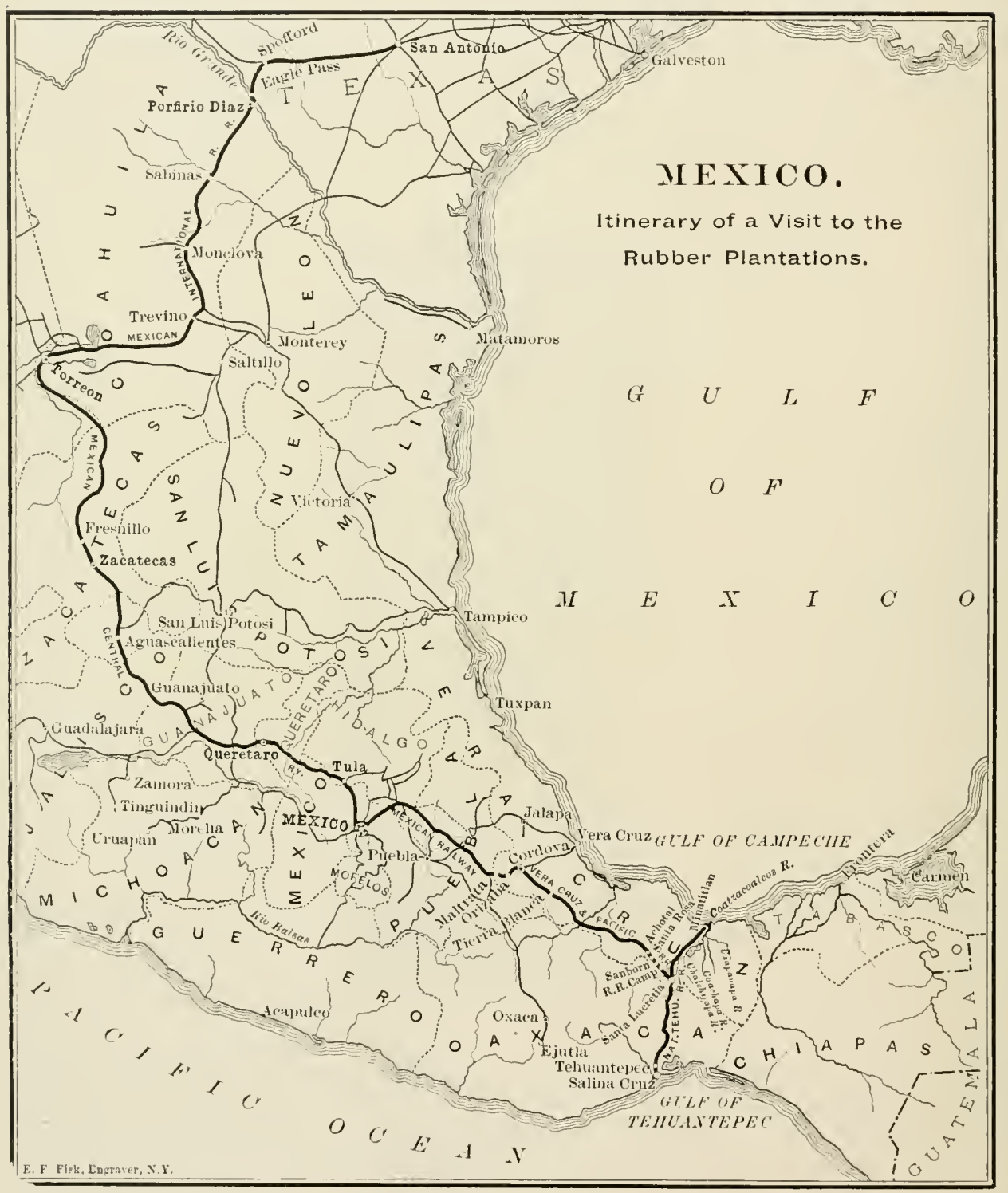


The lester town where we male our entry is kmown as cuislad Porfirio Diaz-the first worl meaning "eity." Here all wats Spanish, or rather Mexican, the athobe houses, the half clat ladlian children whos bexged softly. "un contaio Sonor." and the placid, care-free appearance of the ratiloald men, who hat the air of having but little on their minds, and 110 canse for hurry or worry, were all in marked contrast to the lnustling, bustling atmosplere that is so much in evillence on this side of the border. After pulling out of Diaz, we retired. slept soundly, and waked to breakfast in Torreon, three thousand seven lumblred feet above the level of the sea. It was a real Mexican breakfast, although conked and served by Chinese, and eaten in a leisurely way that dicl not at all suggest a waiting train.

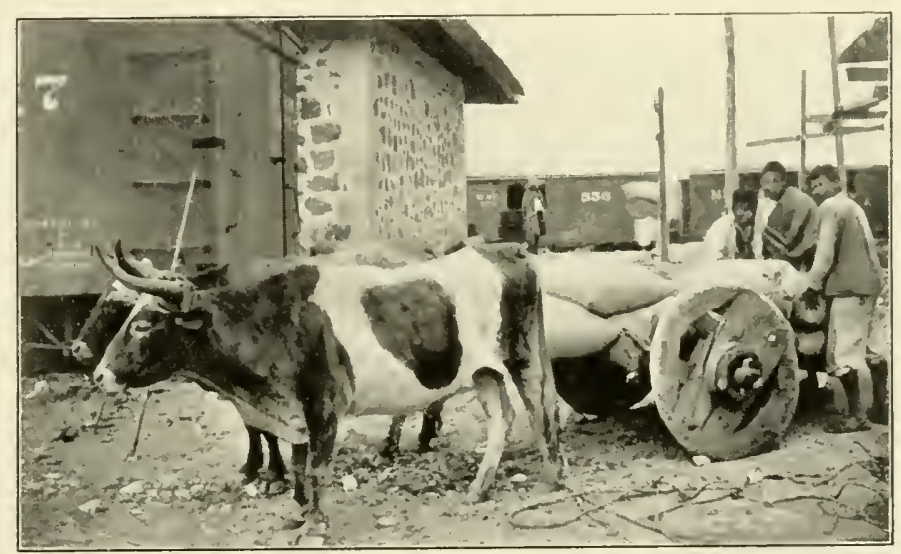

PRIMTINE MFANS UF TR.INSURT.ITIN

To digress a monnent: When I say we, I refer to myself and whatever chance acquaintance 1 might be thrown in with at the moment. As far as Torreon I had had three such-a sugar planter who left at St. Louis: an army officer, home from the Philippines, who got off at San Antonio, and a young English nining engineer. who was to establish himself permanently at Zacatecas. The last named was a nice fellow, but rery serions withal, and responded with extreme reluctance to any attempted humor. For example, he had noted, as I said, the influx of Americans to the comntry, and said:

"By the way, those planters now. what do they raise?"

I replied, "The older ones, who are settled down, raise pineapples, cacao, and rubber: most of the younger ones raise Cain." 
"But don"t any of the older ones go into the sugar business, too?" he inquired.

The whole of the first day's ride on Mexican soil was through a lofty plateau, very bare and dry, the chief regetation being the giant cactus. In spite of the closing of the car windows, the fine allali dust sifted in, coating everything, and making it quite difficult to breathe. Towards evening we reached the mining city of Zacatecas, which is more than eight thousand feet above the sea level, where we were told that we should have difficulty in breathing, because of the rarefied atmosphere. As a matter of fact, none of us suffererl the slightest inconvenience. We dicl suffer a clisappointment in not being able to see the city, which lies hundreds of feet below the railway, lout niglit lad fallen,

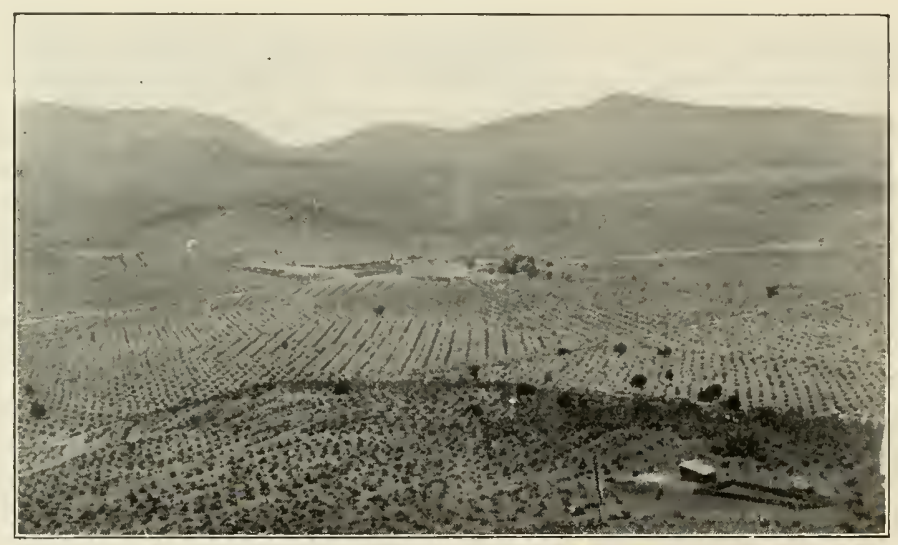

MAQUEY PLANTATION NEAR MEXICO CITY.

and we could only guess its location from the twinkling lights far below us. The next morning we passed through Queretara, where Maximilian was excented, and breakfasted at Tula, a station some miles further on. Here we were introduced afresh to the staple articles of Mexican food, the tortilla and the frijole. The former is a flat cake of mnleavened bread made of corn Hour, that tears like blotting paper and is about as palatable. It is made ly the native women, who treat the conn first with a solution of lye to destroy the outer skin, and then they crush it on a little threeleggerl stone table, called a matate, by means of a stcue mano or rolling pin. This, mixed with water, is baked, and is apparently nutch prized by the natives. The frijoles or Mexican beans are of two kinds, negros and blanca-that is, black and white. To my palate the black ones are 
altogether the lest, althomgh I enjoyed both. The Mexicans are also very fond of meats which are cookerl almost as sonon als killerl, and therefore, apt to be tongh. In their cooking they use a great deal of lard and make a greasy compound that a gringo stomach funds harel to digest.

I think it was at Tula that we got a first sight of Mexican opals. It is well known that almost every visitor to the land of the Aztecs has a vision of the purchase of opals at an exceedingly low price, and the best of stones at that. It was here that we all hat our chance. Several dark hued vendors showed packages of stones that were beatuties. The asking price was high, however, and was lowered only when the train began to nove. We all knew what this meant. A hurried assent, the transfer of the coin and the package of opals. and the subsecuent dis-

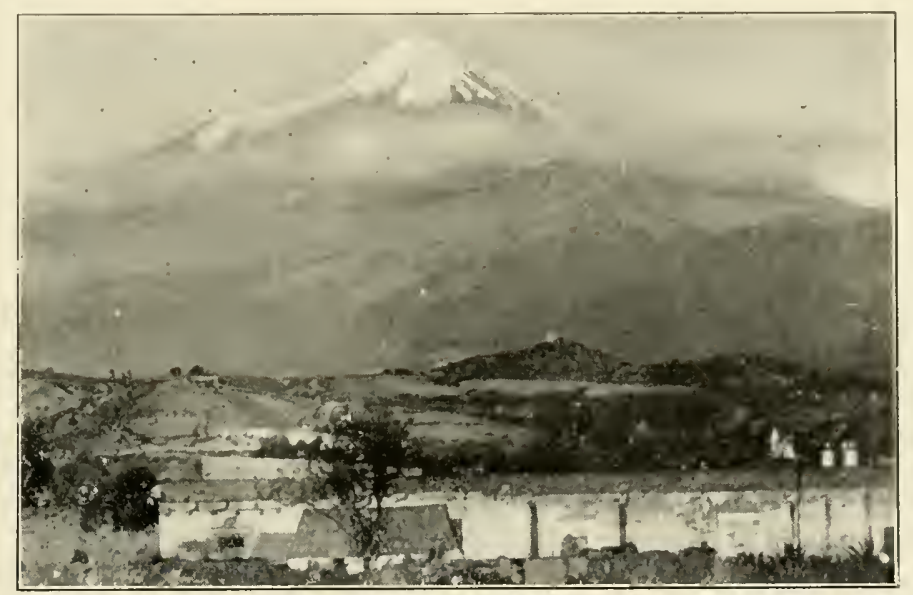

SNOW CAPPED (ORIZAB.A

covery that another package of less valuable stones had been deftly suhstituterl. So we all refused to purchase. Dicl I say all: One shrewd Yankee watched his chance, made his purchase, and cane back chuckling.

"I fixed that moso," le said: "I gave him four big Mexican cents instead of as many quarters." When he opened his packet. however, his face fell, for it contained only common pebbles.

I few miles south of this we had a fine view of the great Nochistongo Canal, which in some parts is six hundred feet wide and two hundred feet deep. It was begum back in I608, as a drainage canal for the valley of Mexico. The railroad runs for miles by the sirle of it, and when one appreciates the fact that every bit of the earth was taken out in 
baskets on the backs of peons, the magnitude of the work is appalling. The canal was never completed, as there was an error in the levels, amounting to about forty feet, over which the water refused to run.

Soon after this the eternal snows of Popocatepatl and Ixtaccibuatl sprang into sight, and althongh few of the passengers prononnced either of the words correctly, all seemed to be sufficiently impressed. IVe learned here that the former of the two mountains had been purchased by the Standard ()il Co., who are to work the rast sulphur deposits in the crater aloove the snows. The second volcano was exploited to us by a polite Mexican who said that the Aztec name meant "the lady of the snows," and he pointed oiit that the irregular peaks of this mountain. with their snowy mantle, took on the figure of a woman lying on her back with her arms folded. All the rest of the party said that the likeness was perfect, and to save trouble I agreed with them, but it really looked more like a couple of huge circus tents fresh from the laundry.

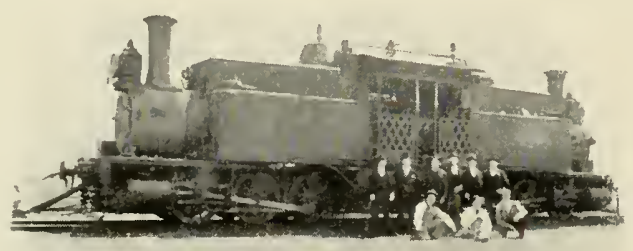

MOUNTAIN CLIMIBING ENGINE

Shortly after this, we reached the City of Mexico, took a carriage. drove to a hotel built in a hollow square, with tiled floors, stuccoed walls, and rooms without baths. Here we unpacked onr traps, sent out and bought soap, and spent two hours in making alkaline solution from the various strata of dust that had settled upon our editorial person.

It was midlay, and hot-unconfortably so in the sum; and just here I want to speak of the climate of the eity. and then dismiss the matter forever. It may be all that is claimed for it by guidebooks and railway folkers, at certain seasons, but it struck me as far from perfect. At night it was so cool that a heavy suit and a light overeoat were necessary, while in the micllle of the day one yearned for pajamas and sandlals. When one gets really chilly, there seem to be but two places to get warm; one is the [nited States and the other the Isthmus of Tehuantepec. 
There doesn't exist a fireplace, a stove, or any sort of heating apparatus. in hotel or private house. Indeed, the inhabitants of the city claim that such are unhealthy, and the result is that every stranger courts pnenmonia, unless exceedingly careful. The city itself is beatiful, and has a chocolate-colored policeman at every conser: a polite little chap who appreciates a tip or a good cigar. and who will do anything in reason for the well behaverl.

I spent two days in the capital, and was very much impressed with its beaties. For a description of the buildings, customs, and places of interest. one need only turn to the many excellent guidebooks on sale everywhere. There are two points, however, which these publications do not touch upon. One is the very sincere and deserved admiration which

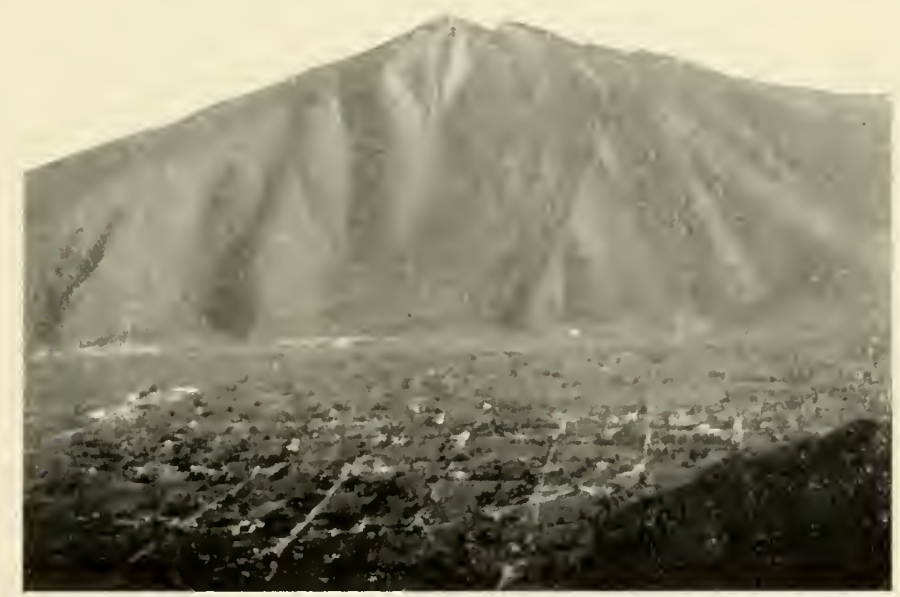

LOOKING DOWN UPON MALTRATA FROM THE TRAIN

visitors of every nation openly express for President Diaz, and another is the fact that American moneymakers, in a great variety of lines, are getting a very strong foothold in the city. to its marked benefit and to theirs.

Like any other tenderfoot, I had brought with me a lot of luggage. which a closer view of conditions in the Terra Culicute showed to he unnecessary. Most of this I left in the City of Mexico, and started forth early one morning, clad in a summer suit, flannel shirt, and broad-brimmed hat, with a Colt thirty-eight strapped to my waist, and bearing for luggage, a smail bag and a Mexican blanket. I found the conditions on trains south of Mexico City radically different from those to the north. 
There were, for example, first, second, and third class cars, with no Pullmans. The first class car might have been a baggage car for all the luggage that the passengers had, and it might have been a smoking car for the way in which both sexes smoked cigarettes; indeed, it might have been a barroom for the way that the train boy served native cognac and beer. My seatmate, a powerful Swede, appreciated some of these Providences more than I did. As he was interested in rubber planting, and particularly as he understood Spanish, we becane quite friendly, and before I knew it he was taking my trip right ont of my hands. He verbally hustled me througl Mexico, and by this time would have had me in Patagonia, had I not put on the brakes.

The first part of my journey from the city, the road ran through enormous maguey plantations, from which Mexico's national drink, the

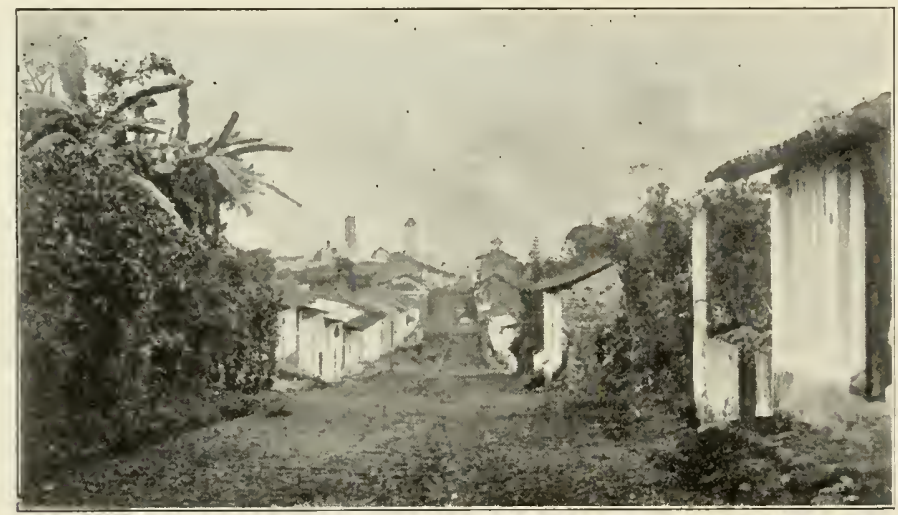

STREET SCENE IN CORDOBA

pulque, is drawn. Then, after miles of dusty plain, the road (near Esperanza) runs close to the mountain side, disclosing, some four thousand feet below, the little native village of Maltrata. Zigzagging round the mountain, tunneling through projecting rocks, clinging to the edge of awful precipices, the train curves and slides, until it finally gets down to the plain, and the powerful double-headed locomotive which held it back stops with a veritable sigh of relief.

Leaving Maltrata, the course still contiues down hill, following the windings of a mountain stream some hundreds of feet below, until we finally sight Orizaba, clothed in eternal snow, lifting its head high above all surrounding peaks, and to my mind far more beautiful and inpressive than Popocatepetl or its sister summit, over which tourists rave. After 
a bricf stop at the mumntain herlecel city of ()rizaba, we left the train at Corloba, where the spantish of my traveling companion was most helpiul in securing accommodations at a litte Mexican hotel, where we hád a really gook dimner and comfortable beds.

In the morning we took an early train over the lera cinz and l'acific road for Aclotal, its terminus. Nithough the rum is not a long one. it takes from six oclock in the morning till one the following morning to make it.

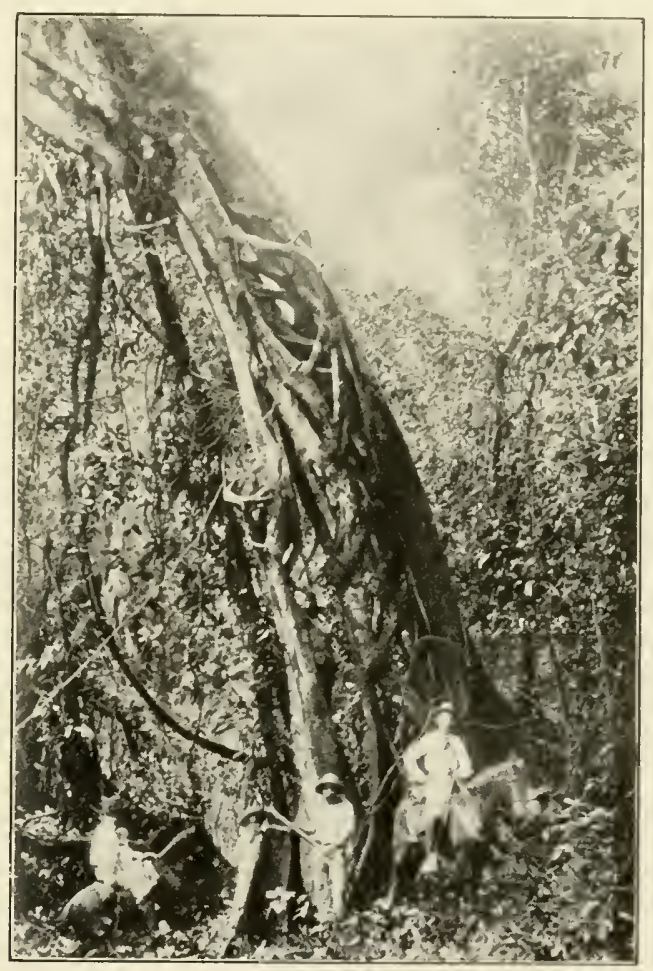

FICUS BEN JAMINA.

That we were getting into an unsettled country was much more apparent than ever before, the cars being suarded by rurales (the native military police), and the passengers, both Americans and Mexicans, having the free and easy demeanor which characterized the early dass of the Far West. The conductors and train hands were Americans, as were many of the passengers, all of whom were going south and most of them interested in rubber planting projects. As was natural, the Americans 
and English gravitated together, and I heard many interesting facts concerning the country and much concerning rubber planting. The verdict of those who were not directly interested in the business seemed to he that there was nothing in it, and that rubber trees could never be grown. Indeed, one passenger said flatly that he had been in the country a number of years, but he had never seen a rubber tree, and didn't believe they could be grown anyhow. This did not seem to disturb the serenity of the planters who didn't argue the matter at all, but let the others talk. We passed a rather

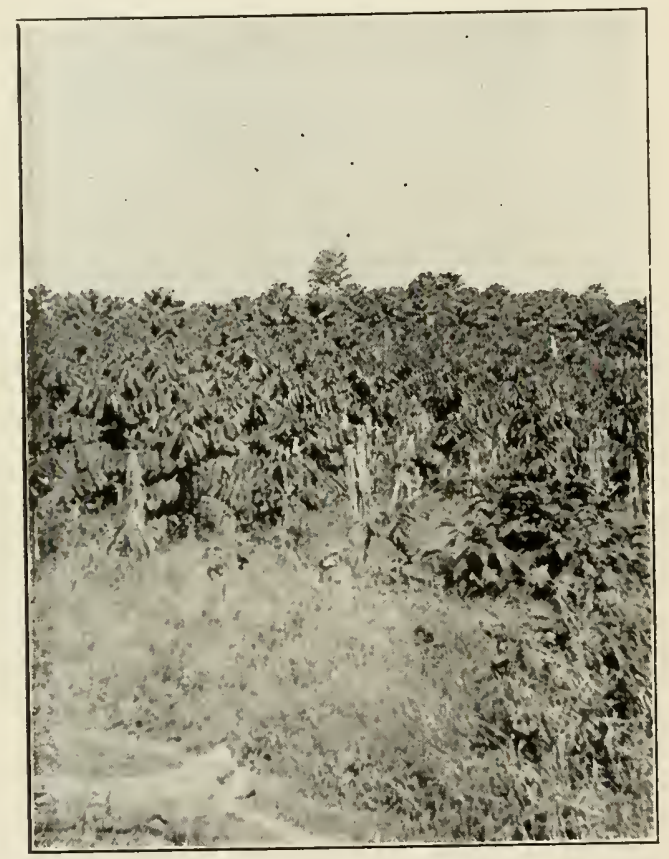

LA, JUNTA CORNER OF RUBEER FIELD ONE YEAR OLD.

wearisome day on the train, stopping occasionally for meals and getting them served more and more in pioneer fashion. I had intended to stop off at Tierra Blanca, in the vicinity of which are large plantations, but learning that the men whom I most wished to see were absent, I left that for a later visit. Finally, at one o clock in the morning, we reached Achotal, the train returning at once and leaving us standing on the platform of the only frame building in the place, the depot. Which was promptly locked. 
I am moved to tell of my experience at Achotal, not to deter the timid or comfort loving from venturing into this part of the country, but as a bit of history, for within a very few months it will cease to be a pioneer railroad terminal, with its tramps, its native workmen, and its flourishing cantina, and it will settle down as a safe, prosaic, Mexican way station. In fact, this clange was almost due when I was there, for track had been hastily laid and construction trains run down to Santa Lucretia, where it is to join with the National Tehuantepec Railway. This construction train, by the way, we were to take sonce time about six oclock in the morning, and after riding about fifteen kilometers, I planned to stop at Santa Rosa, and thus reach a large private rubber plantation operated by an oldtime friend of mine.

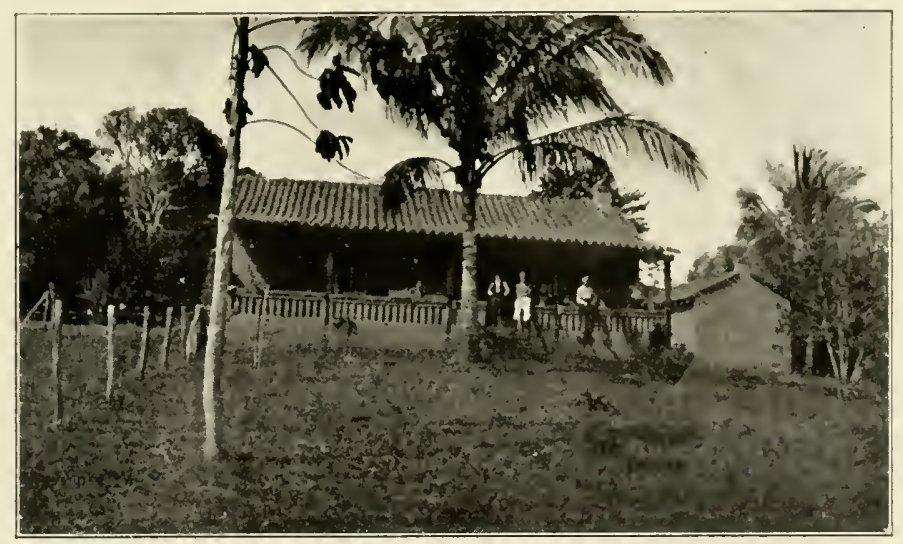

LA FLORENCI1.-PLANTTATION HOLSE.

To be left in a town like Achotal at one oclock in the morning. with the knowledge that it would be hard work to get a bed, is not a particularly cheerful prospect. One of my planter friends. Mr. M. L. Arlams of Ixtal. however, whom I shall always remember gratefully, piloted me across the mudely track, walked me over a narrow, springy plank which rested against a steep bank, and I saw fronting me the few palm thatched native huts which make up the town. Entering one of these, we found that there was no room at all, every available space being taken by canvas cots and conscientious snorers. Leading me further up the hill, however, he forced his way into another lut, roused the owner, and finally secured for me a cot. This I took possession of. and prepared to 
make nyself comfortalje, as harl a half dozen Mexicans, each of whom had a similar resting place.

All were not asleep. however: in fact. my nearest neighbor, a muscular young moso, was just disrobing. While he undressed, his hat, which lay on the cot, showed that it was preempted. Everything was peaceful: the snores of the sleepers, the stamping of the horses outside, the grunting of the pigs that had come in the open doorway and were seeking what they could devour, and the scratching of the flea tormented

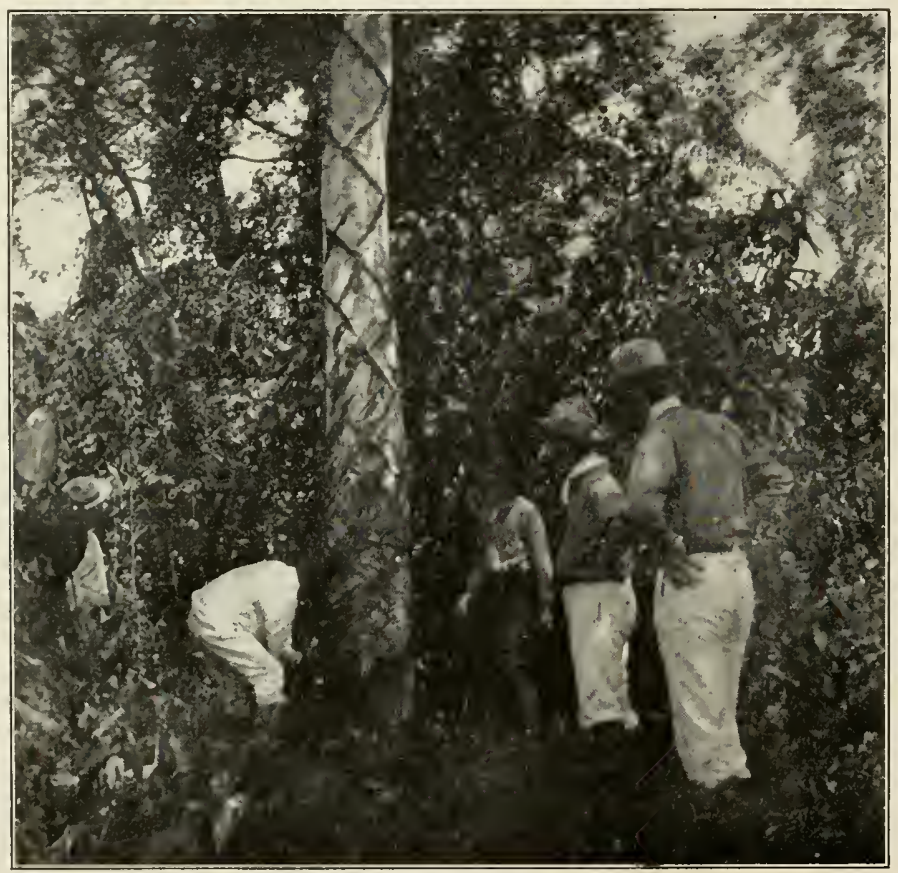

L.A FLORENCIA.-TAPPING L.ARGE WIID RUBPER TREE.

dogs, being the only sounds of life. Breaking in upon all this peace came the big Swede, with a very substantial "jag," and took possession of the moso's cot, throwing his hat upon the floor, wherenpon the native drew his knife, preparatory to a pointed argmment. Not that I cared particularly for the mozo, or for the Swede, but in the interests of fair play I interfered, telling the latter that if he insisted upon taking the cot, the moso should have mine, whereupon he went ont with some grumbling, and wrapping myself in my blanket I went to sleep. feeling 

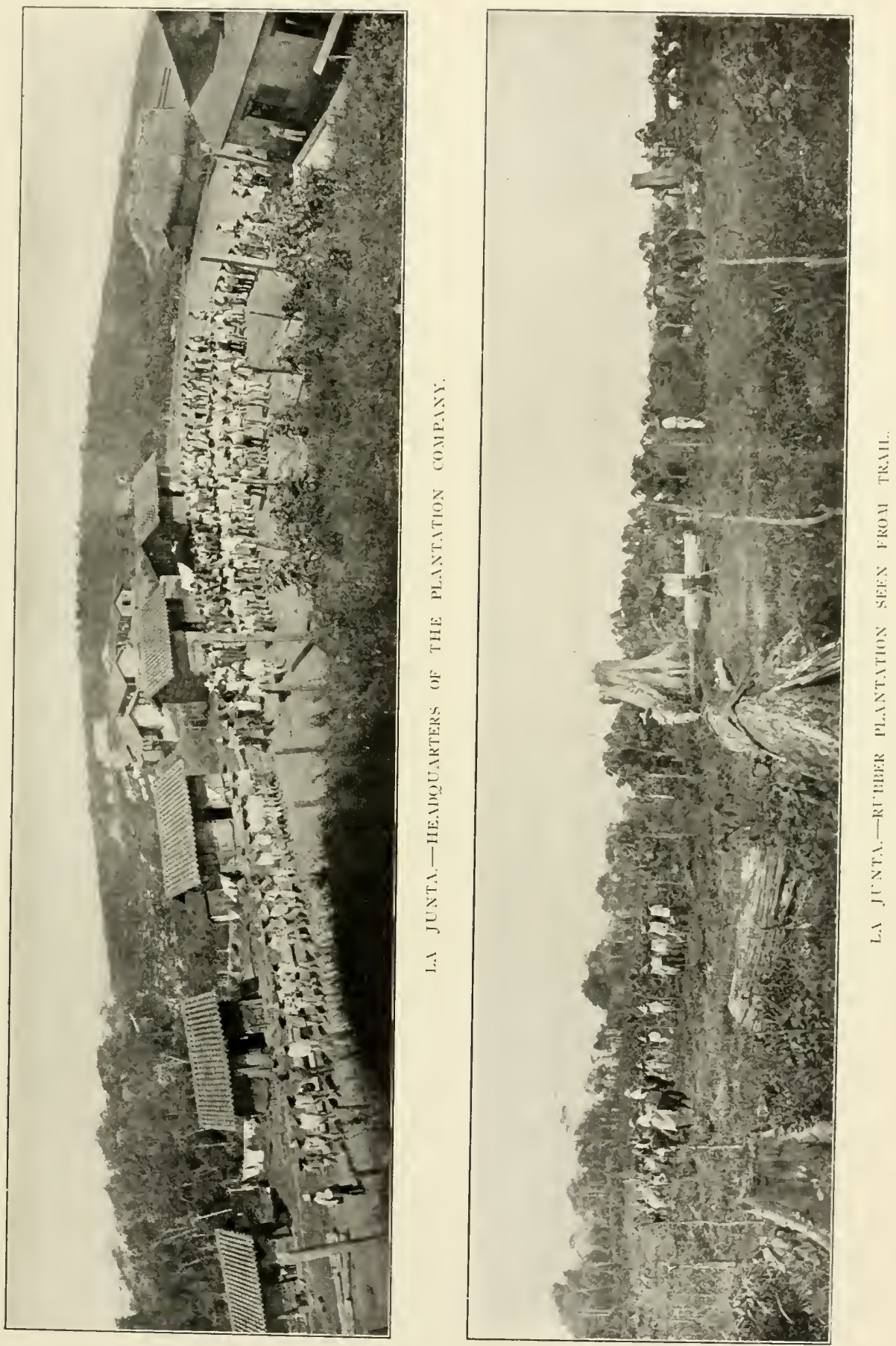
that I had done a good turn for a dark-skinned, downtrodden brother. I was not to rest long, however, for I was awakened by the reentrance of the Swede, who came to inquire politely if the strangeness of my surroundings kept me from sleeping. I assures him they did not, and he departed satisfied, and I dropped off to sleep again. Suddenly, however, I was awakened by the feeling that some one was looking me in the face, and opening my eyes I saw the mozo with his face about three inches from mine and his hand ontstretched toward my breast pocket. I have forgotten just what I saicl to him, but it was most emphatic, and he went back and lay clown, while I, wrapping my blanket tightly about me, dropped into another doze, but not for long. Back came the Swede, with more of a "jag" than ever, and sat on the side of my cot, and wished aloud that he had a place to lie down, so I got up, and gave him my cot. and went and sat in the doorway, and smoked and thought.

At five o'clock I succeeded in getting some coffee, which greatly: refresherl me, and at nine oclock I boarded the construction train, which was made up of a wood burning engine, a boxcar for passengers, and two flat cars loaded with railroad ties, mozos, and negroes. We crept along at a snail's pace over the temporary track which was not ballasted and which had sunk almost out of sight, sometimes, in the clayey mud, and sometimes it slid a foot or two to right or left, threatening to overturn the car. That this latter was no idle dream was indicated by several boxcars which we saw that had been tipped off into ditches along the sirle. We finally reached Santa Rosa and disembarked-that is, I did, and my cheerful planter friend, Adams, while all the rest went on. Santa Rosa station is not a large one, the only building there being a ruined lut of native build that had been in use when the pioneer railway camp was there.

On the opposite side of the track, however, the land had been clearerl and planted to Castilloa, a part of the Demarest estate, my first sight of the cultivated trees. They were growing on a well drained hillsicle, in a rich, loamy soil, with a suinstratum of clay, and although shedding their leaves, as they always do at the begimning of the dry season, they looked thrifty and healthy. My companion sent one of his men off through the forest to secure horses, and while he did that 1 (lrank in the beauties of that tropical scene. It was a glorious morning. and everything possesserl the charm of novelty. The huge forest trees. studded with orchids and epiphytes, the marvelously dense growth where nn clearing had been made-a growth of trees, vines, and climbers so thick that it would have been impossible to so ten feet through it with- 
out cutting one s way: the parrots chattering in the frees, the lorilliant macaws flying to and fore, and the wealth of thowers, big and little. hekl me spellijound. I was awakened from my revery ly Mr. Mrlanss. Who led me irp over the hill where lived the owner of the rubber trees, who weleomed us warmly, and prepared an abmudant meal, chatting most entertainingly about the comutry and its prospects.

After a sicstu, the horses having come. we mounted and trotted

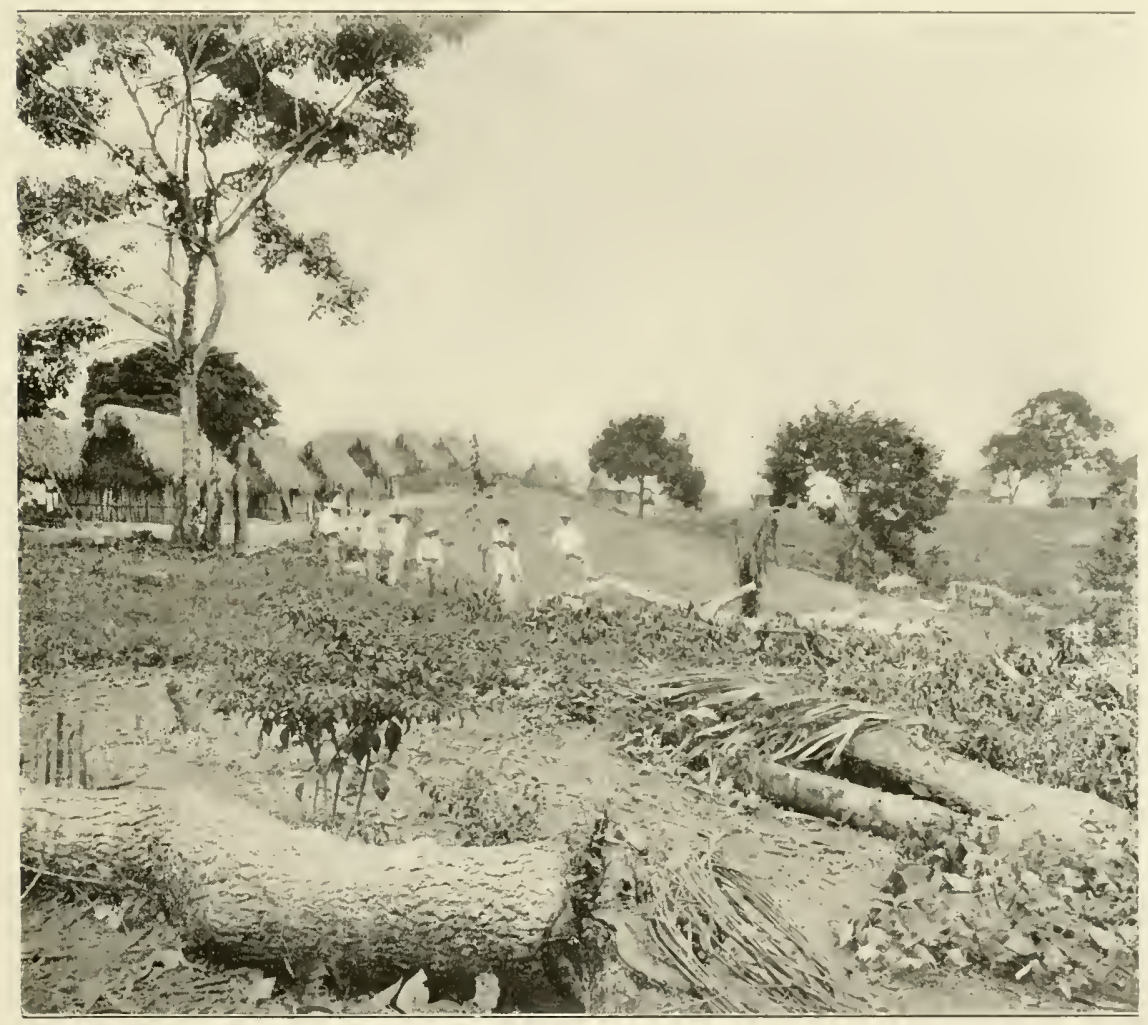

INTERIOR 1 IMP NO. +. ON PI.ANTATIOX RERIO.

gaily away: that is. Mr. Aclams did, but as I hat not heen on horseback since I was ten rears old. I felt anything but frivolous. I Mexican saddle, however. lept me within bounds, and very soon the trail enterel the virgin forest and got so rough and muddy that the trot calmed down to a walk, much to my satisfaction.

I dont think I sliall ever forget one particular place in that roarl. 
where we had to cross a mully ravine with steep, clayey banks on either side, or how 1 sat back as far as possible while the horse slid down to the bottom, and then suddenly reversed my position and got one hand tight in his mane while he scrambled up the other; nor will I forget how he tried to get ont of the mud in the middle of the trail by walking close to the trees, and of 11 y frantic efforts to keep him away from the spiney palms and numerous other bristling projections of the forest. We finally emerged into the open, however, and as we came ont my companion asked me how I liked it. I had by that time gotten into the spirit of the thing. and was thoroughly enjoying it, so that I could conscientiously say. "First rate."

"Well, that's the worst trail around here," he replied: "I thought you might as well have that at the begimning."

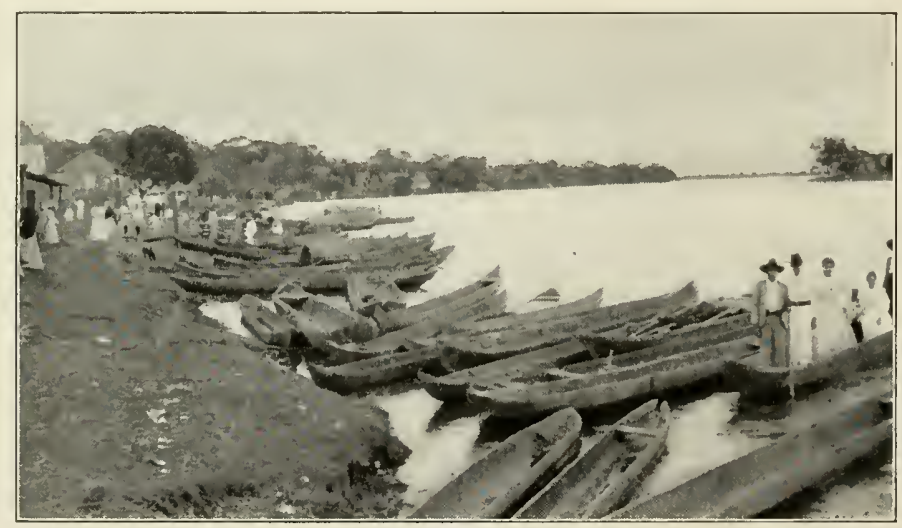

WATER FRONT AT MINITITLAN.

[Copyrighted Photo by C. B. Waite, Mexico.]

The rest of the ride was through a magnificent stand of cultivated Castilloa trees, planted on rolling ground, about nine feet apart, showing every evidence of intelligent care. Half an hour later. we clrew up at Newmark's plantation, which is known as El Ritero, and is a private venture, enloracing some four hundred acres of land, on which are about fifty thousand rubber trees, planted four or five feet apart in the rows. They looked finely, and indeed the whole place, with its coffee, bananas, etc., appeared to be most flourishing. Here I was treated to a small red lamana about the size of one's thumbl, that was the most delicions lit of fruit one can imagine. I now parted from Mr. Adans, and being taken 

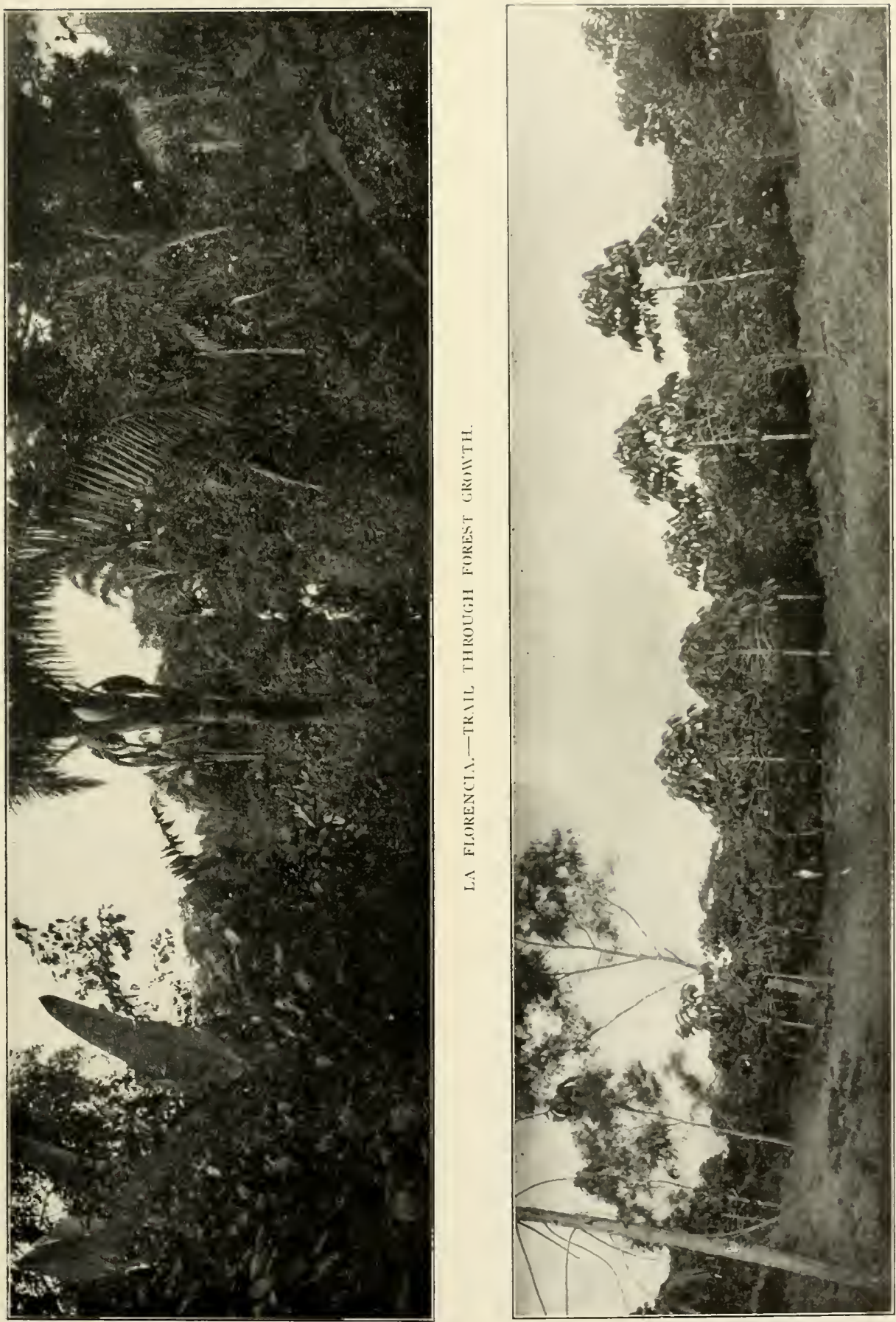

\begin{tabular}{l}
0 \\
\hline
\end{tabular} 
in charge by Mr. Newmark, soon reached La Buena Ventura, and entered the house that was to be my headquarters during my stay in the Trinidad River district.

I had not seen my friend Harvey, the founder of this tropical enterprise, since we dined together at the Lotos (luh) in New York four years before. He was then yearning to shake the snows of the north from his feet and hasten back to the land where winter was unknown. I doubt if he believed that I would ever redeem ny promise griven then $t o$ visit him. and it was not for some time that 1 learned the cause for this skepticism. It seems that many northemers come to the (ity of Mexico-some venture to Orizaba and points easy of access further south, but few get as far as Achotal. Only a short time previously a well known New Jork lawyer arrived there at one in the morning, saw what he was "up against," boarded the train, and started back, though within ten miles of his destination. And that was why my host exclaimed, "By Jove, you are really here!" 
SEL(ND LETTER.

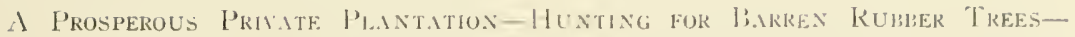

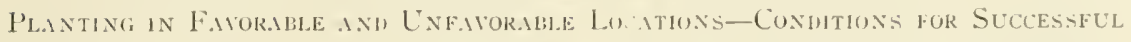

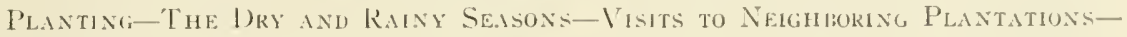

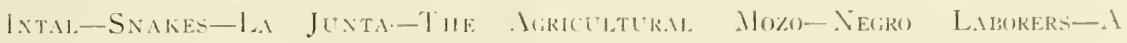
MHNIGHT RHE-FREEHOM FROM PI.ANT PESTS.

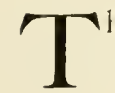

$11 \mathrm{E}$ site of the plantation, La Bunena lentura, five years ago was virgin forest. At that time Mr. James $C$. Harvey and his son, Clarence, purchased for themselves and their associates, (a private corporation), one thousand acres of land and prepared to develop it along the most practical lines. When the senior Mr. Harvey came to Mexico, it was with the idea of planting coffee, lut after months of study and a personal inspection of most of the Isthmuns comntry, he decided that India-rtibier offered the hest opportunity for profit, and therefore he has turned the larger part of his land into a plantation of Castilloa clastica. I an enlarging upon this trifle because, to my certain knowleclge, the gentlentan under consideration is not only an expert horticulturist and botanist, but has studied tropical agriculture in Central and South Anerica, and in the East Indies and W'est Indies. and beyond this he and his associates offered no stock for sale, but went into the business to make money out of their own investment of capital, energy, and knowledge. Such a plantation must. withont fail, give the visitor the best possible view of the practical end of the business. There are. of conrse, many such private estates in the tropics, but it happened that this was the one that 1 knew most of, and to risit which 1 had a most cordial invitation.

Here I was, therefore, installed in the pahm thatehed house, with its earthern floor and lamboo walls, that for five years had been the home of these hardy pioneers. The clomicile was sitnated at one encl of a long ridge. on each side of which, with a rare eye to effect, were planted gorgeous flowering and foliage plants, and trees valuable for fruit and for ormanent. Very modestly the presiding genius showed me sixty-five different species of palms, probably the largest collection in the Americas. Not only were there palms native to the tropical parts of America, but there were specimens from Java. Cerlon, New Guinea. Queensland, the Fiji Islands, New South Wales, and a score of other remote places. These were gathered, not as part of the planting proposi- 
tion, but from a plant lover's interest alone. which they seemerl to appreciate by growing lixwriantly.

Then, too, I must not forget the collection of orchids that hung from the bamboo lattice ontsicle of the house, and clung to the trees on all sides; nor the orange, lemon, lime, grapefruit, banana, and plantain trees, a notable part of the garlen equipment. I looked with interest also on the vanilla vines, the cacao plantation, and the twentyfive varieties of pincapples, but my chief thought was rubber, and so I soon fomnd, was his. I do not wish to make my planter friend blush, but when I found the work he was doing, how widely he was consulted by planters both in Mexico and in listant tropical lands, I was more than ever impressed with ny. wonderful luck in thus "striking oil" when first I began to bore. So I asked questions, and questions, and questions. and took notes most copionsly all the tine.

One of the first points that I wanted settled was, whether here or elsewhere, there were Castilloa trees, either wild or cultivated, that did not yield later. So we both started out to find one such tree. by cutting the onter bark-indeed, (luring all of the trip. I cut trees by the hundred just to prove this point-but found none except in one instance. I was much interested also to note the differenees in the latc.r as it issued forth. In some instances the tree wonld send ont a perfect shower of milkwhite drops, which coagulated rather slowly, while another near by would exucle a thicker fiuid that began to coagnlate almost innuediately. The natives clain that this latter tree is simply so rich in rubler that it retards the flow, and that after a little tapping, it corrects itself and the later becones more fluid.

The younger trees gave out abundant later. but those that were less than four years old gave a milk that seemerl inmatmre: that is, it dicl not coagulate into dry, hard rubber but remained quite sticky.

noted also a curions thing in connection with this, which was that in the yonnger trees the late.1 legan to mature first near the base of the tree, while 11p towarks the branches it still remained of the sticky sort. lint we found no trees in this district that dicl not yield latex abundantly.

At La Pinena Ventura I was able to institute some exeedingly. interesting comparisons between the growth of the rubber tree under favorable and unfavorable conditions. In l,oth cases the trees were Castilloas, planted from selecterl seed. In the first instance they were planted in the open, about nine feet apart. on rolling land whic! hat good drainage. Measuring the circumference of the trunks a foot above the gromud. I got a fair average of 23.3 inclues, and an ectimat 'd average 

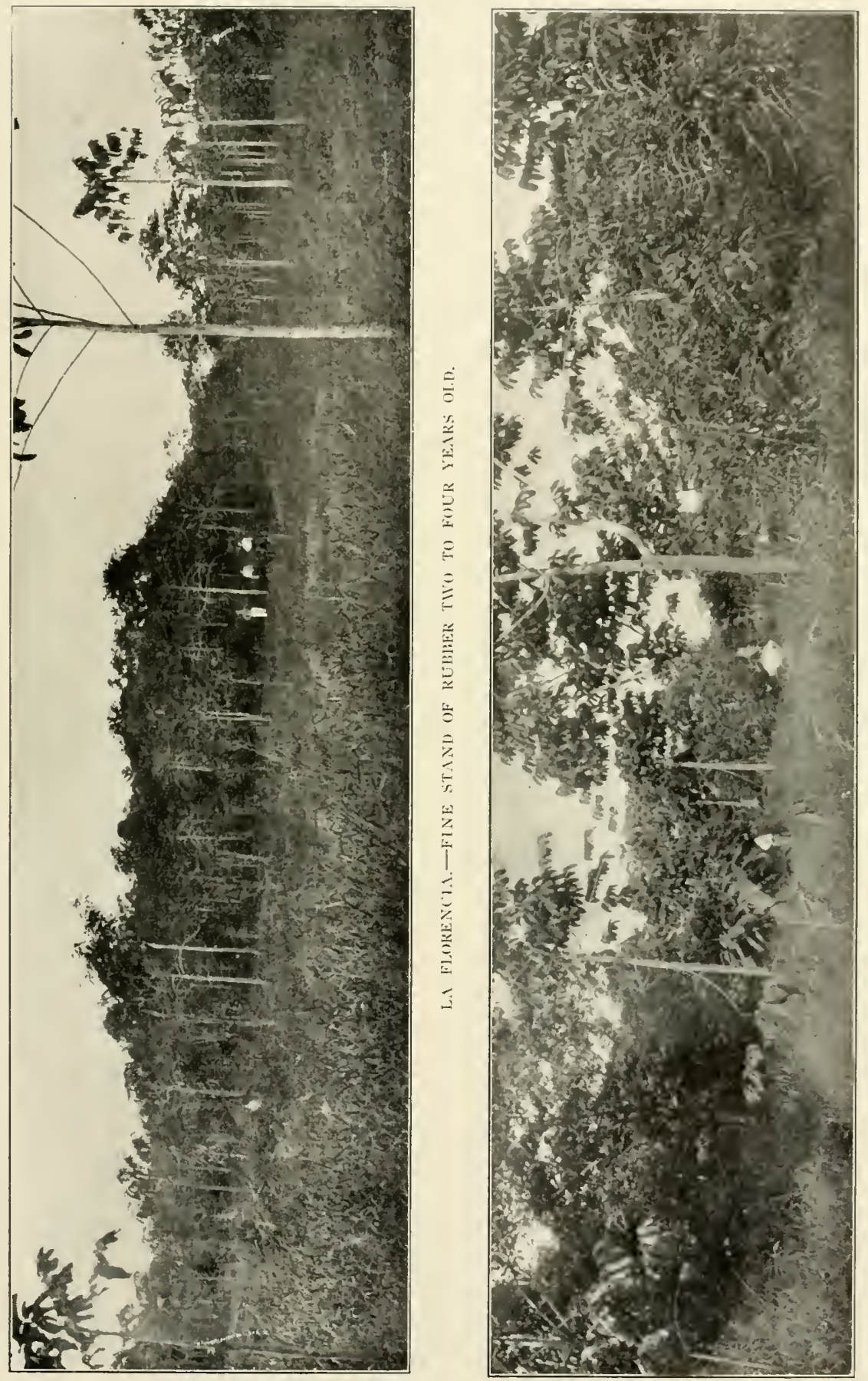
height of twenty-two feet. The banner Castilloa was a seedling planted in the open, that measured thirty-two inches in circumference and twenty-five feet high. All of these trees had every appearance of health and vigor, and gave forth milk abundantly. From the records shown me. they were a trifle over four years old. In the second instance, grown in partial shade, such as produced fine cacao, with the land more level and not well drained, the trees being planted at exactly the same time, and from the same lot of seed. I got an average of 4.6 inches for circumference a foot above the ground, and an average height of six feet. Anyone would not seem to need a more graphic illustration than this of the necessity for observing proper conditions in planting, and further, as a warning against planting in badly drained land or in the shade.

It is well to note that where these failures appeared there were several wild rubber trees that we estimated to be twenty-five or thirty rears old. They seemed to be perfectly healthy and bled freely. The only reasonable explanation of this is that they were seenllings that grew up slowly in the densest sort of forest when the tremendous surface growth was so luxuriant as to be able to partially drain the ground through its great leaf areas, and also lift and make it porous by the leverage of myriads of thrusting roots. The partial clearing of the land later stopped most of this aerrial drainage, and the subsequent rotting of the roots allowed the ground to sink into a solicl, water-sodden mass.

The land at La Buena Ventura scemed to be first leaf mold, then a rich, yellow loam, three or more feet deep, and under that a blue. clayey ooze, as if from the botton of a tropical ocean becl. It was rolling land, as a rule, very well drained, and capable of growing almost any tropical product. The Cistilloa orchard, through which I tramped many times, had in it about two hundred and forty thousand trees, from one to four years of age. All of them were planted from the seed, except a small percentage taken from nursery stuck to make up for the occasional failure of a seerlling.

( )ne result of my early observation, and one that grew with each day"s experience, was the conviction that a knowledge of clinate, rainfalls, soils, drainage, etc., is an absolute necessity from the lreginning. in the selection of suitalle sites for rulber plantations. In other words, the expert tropical agriculturist, well equipperl with common sense, is most likely to be the cne who starts right. For example, one plans to plant the Castilloa. It is a soft, wood tree, a tree that from its physical formation is not built to stand high winds, that with its long taproot 
must have a deep, rich soil, and well drained withal. It is a decidustes tree. Which nicans that at a certatin tine cach year it encourages the presence of the sun's rays on its trunk and limbs. The prospective planter should, therefore, pick ont land that is covered with a growth of soft, rather than hard wood trees, as the latter points to a wravelly soil instead of clayey loan. It should be rolling land, or at least land that is naturally well drained. It slould be soil that will give the tree plenty of moisture during the dry season and yet that will not be soggy during the wet seatson. For a rmming rule, there should he at least four feet of clrainage soil. In the clearing of the land, if there are not natural windloreaks, a certain anount of forest should be left standing to act as such. Referring again to the long taproot of the Custillou.

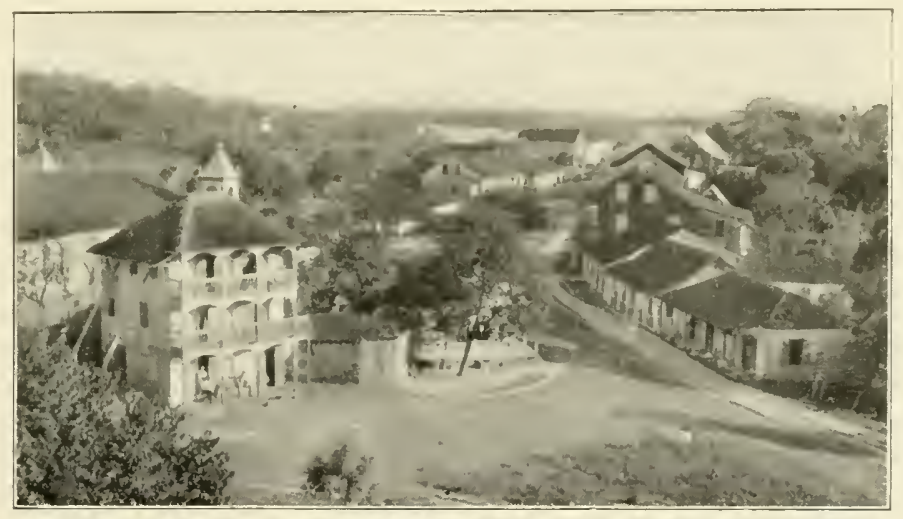

HOTEL PALOMARES, MINITITLAN.

[Copyrighted Photo by C. B. Waite, Mexico.]

it is said that as the tree grows older it often disappears, its place being taken by large laterals.

I struck the Tiorra Culionte just at the beginning of the dry season, and therefore was curious to know exactly what constitutes the rainy and dry seasons in the tropics. Of course, no general answer conld be given, as in different tropical regions these seasons have their own idiosyncrasies. I believe I had but little idea of what the weather was in the rainy season, whether it rained all the time, or was partly rainy and partly clear, and this is what I learned: In the state of Vera Cruz. the dry season runs roughly from February to June. During the latter part of May there are about three weeks of genume het, dry weather. 
Prior to this, what is really the dry season is often broken by rainfall: in fact, it rains a little abont half the time. Beginning with the first of Jume, however, and lasting until the first of September, come the torrential rains, except that there is, in Angust, a week or ten days of dry weather. Nine days ont of ten during the torrential rains, the morning breaks bright, clear and sunshing. Then in the early afternoon heary thunder is heard. followed by the roar of the rain through the forest, the water falling in sheets from one-half to one and one-half hours. It also rains regularly cluring the night.

When night fell at La Buena Ventura, we all went indoors, for beautiful though the tropical moonlight is, fevers are most easily caught after sundown, and particularly if one sleeps out in the open. In fact. native or planter will do almost anything rather than thus expose himself. IVe did sit in the doorway, for awhile, and drink in the glorions view of tropical luxuriance, made alnost as light as day by the full moon, yet softened to a weird, rich beanty that the northern climes cannot equal.

For the first time in my life I slept uncler a gracefully draped series of muslin curtains. As there were no mosquitoes, I thought it rather unnecessary mil my host said that although the country was a paradise, centipedes, small suakes, and tarantulas sometimes dropped from the inside of the thatched roof, and while they were not as poisonous as many thought. I might not care to share my couch with them. I slept under a blanket. it was so cool, and awoke to find awaiting me, at the end of a palm thatched corridor, a fine shower bath. Few planters have them, but Mr. Harvey's English blood, so it is said, impelled him to build this before he had a roof on his house. It was certainly a great luxury, and one to which my thought often turned when later I awoke from a night's alleged sleep in a passenger coach or native hut.

The day was Sunday, and we had coffee and rolls soon after rising. and breakfast about twelve, as is the custom of the country. In the afternoon many neighboring planters rode over on horses or mules. discussed crops, and asked the news from the outer world. They were most corlial in their invitations to me to visit their places, and it was with the greatest regret that I was able to avail myself of only $a$ few of these privileges.

It was during this social Sabbath that I renewed a pleasant acçuautance with the two Fish brothers. Wisconsin Vankees, who were looking at land in that region, and who. I believe, finally purchaseci La Florencia estate, sairl to have the oldest cultivated rubber in that 
district. They were hustling about, secing things in a jolly, breczy fashion that made them most welenme, and they helpen me execedingly by giving ne excellent photographs of nearby estates that I dirl not have an opportunity to visit.

When first I struck la linena lentura I must confess that the languor of the clinate, or else my omn innate laziness, led me to take things very easy. The hammock in the fanily room was most inviting, and in spite of the fact that "l,oro," the green parrot. Watcherl until 1 napped, and then climber down from the rafters and gare me a friendly bite. I luxurated-but only for a couple of dayss, and they were far from wasted, as I drank in lots of information from my h st.

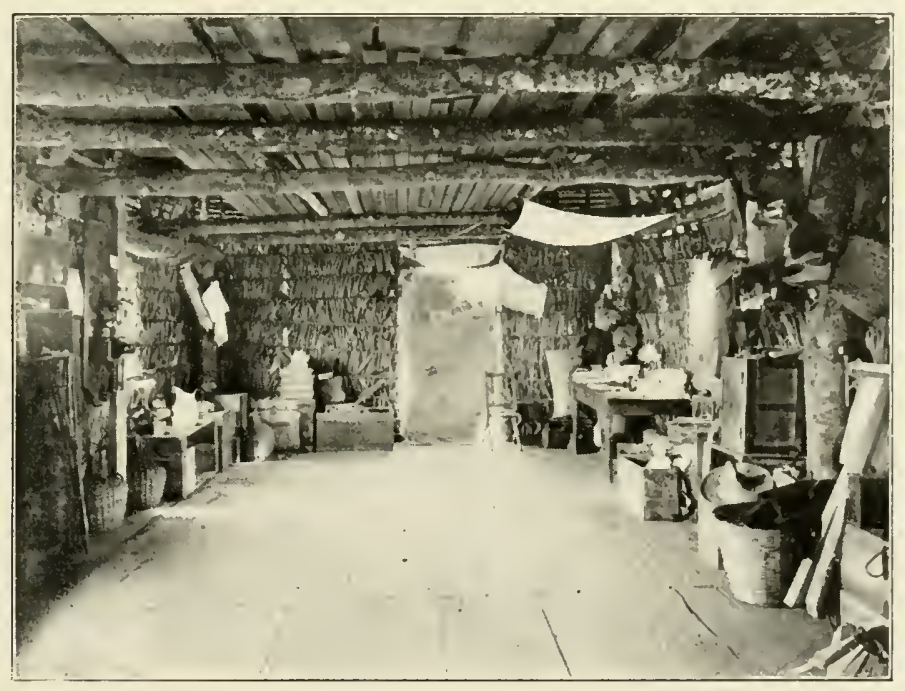

RUPIO.-INTERIOR OF TEMPUR.IRY OFFICE.

The second day we started out to visit the neighbors. I wanted to walk but that was out of the question, so I had my second experience as a horseman. I was devoutly thankful that my little mare was lazynor did I mind it that she always managed to step on my toes just as I prepared to mount. But she (hid take advantage of me when she chose to stop on a log hridge not more than two feet wide and standing on three legs tried to bite a fly that she pretencled was on the fourth. I rid not fall off. Wut had I started her with voice or whip I think I should have. She harl a habit, too, of imagining she saw a snake ahearl in 
the trail, and suddenly leaping to one side. I stayed with her every time, and am still just as much surprised at it as she was.

Onr first visit was to Ixtal, where I again had a chance to thank Mr. Adams for his earlier helpfulness, and also to meet his right hand man, Mr. Stewart. It was to my mind the hottest clay we had experienced, when we finally reached the ridge upon which the plantation buildings were located. Py that time I was getting to be somewhat of a connoisscur in rubber trees, and so, after the noon breakfast, was glad to accompany Mr. Adams on a tour of inspection. Here were some two hundred and fifty acres planted to rubber, the oldest trees being four years, and the total number about one hundred and fifty thousand.

The land was very similar to that at La Buena Ventura, and the growth about the same, although in a part of the plantation the trees seemed to be a little taller. Late. flowed from them all abundantly, and my guide said that he had never found one that did not show plenty of milk. In discussing this question, Mr. Aclans told of an Australian scientist who had been in that region, and who claimed that there were three native Castilloa species, only one of which was a rubber producer. They all looked alike, so he said, and the difference in them could only be detected by a careful examination of the cellular structure of the leaf. He said further that he uprooted eighty per cent, of his own first year's planting, because he did not know this. When he finally did get the right tree big enough to tap, it bled so freely that he was obliged to stop the cuts with clay, else it would have bled to death. We were able to assure Mr. Arlans that this was not credible, to which he agreed.

One of the officials of Ixtal, 1)r. Butcher, has a very pretty lome not far from the plantation healquarters, at which we called on our way back. The Doctor and his wife received ws hospitably, and while the others chatted on neighborhood topics, the head of the house took me out and showed me the skin of a big snake that he had just killed. Now one of the common rlreads that the tenderfoot carries with him in the tropies is that of snakes. It would be folly to believe that there is no danger from them, when one considers the inpenetrable jungles and the conditions that nature has prepared for an ideal reptilean existence. Is a matter of fact, however, cluring the whole of my trip I dirl not see a single live snake, big or little. I clicl see the slins of some very sizcable ones nailed to walls of the planters houses, such as that which Dr. Putcher shower me, but even those are rare. The planters say that this is clue to the fact that the woods are full of will 


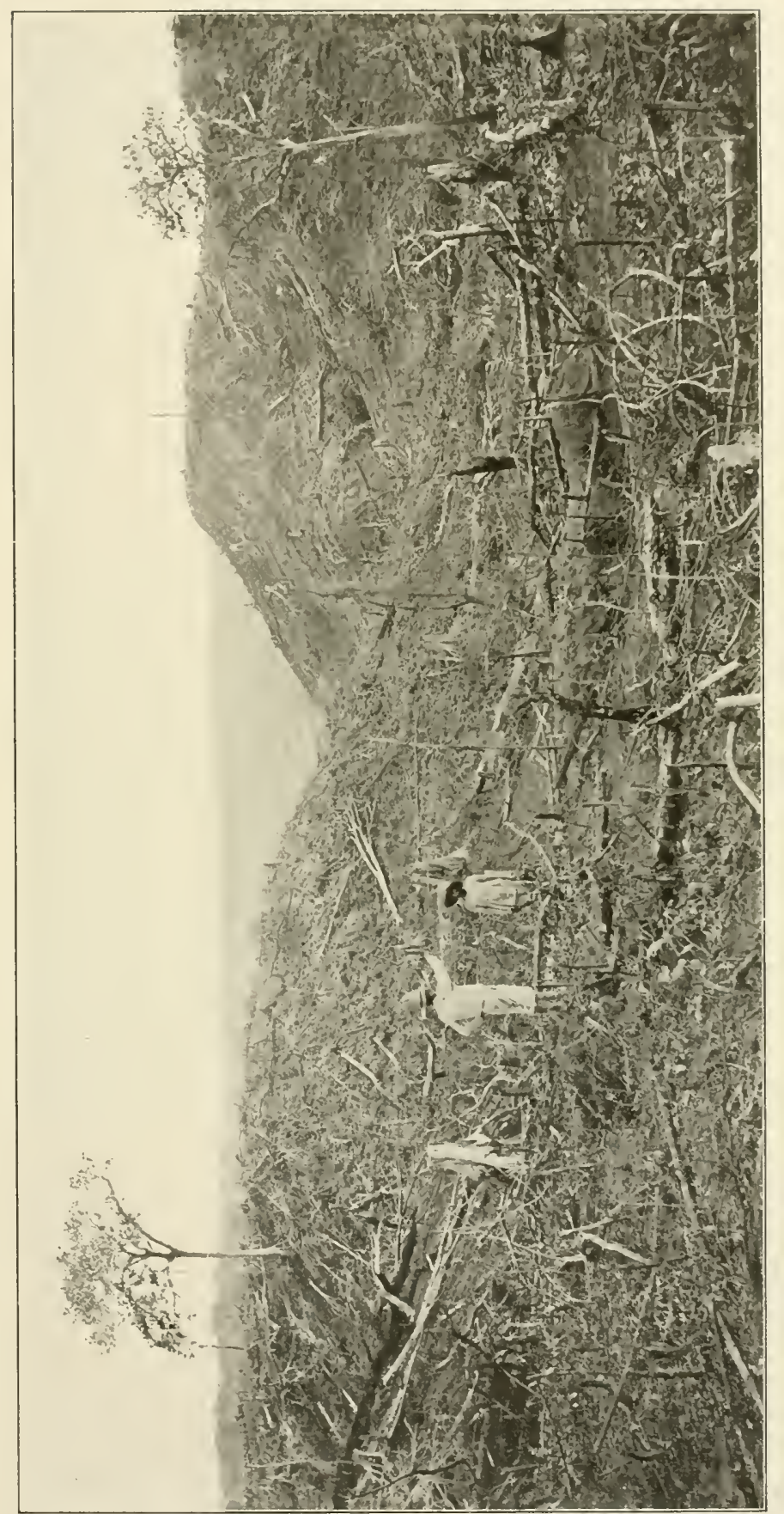

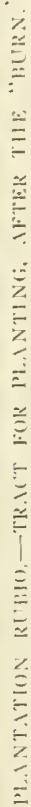


hogs that consider any kind of snake, poisonous or otherwise, a great delicacy, and that those that escape the hogs are very likely to be canght by the hawks, which are very abundlant and always on the watch. There are only two really poisonons snakes there, as far as known: one is the rabade heuso. which is small, quick, and very deadly, and seems to have a special antipathy to mules: the second is called by the natives the "sorda," and is something like the diamond rattlesnake, but has no rattles. It has poison fangs an inch and a half long. is very slow to move, and quite poisonous. There are also small prthons and some big black racers, both harmless, however.

We returned to La Buena Ventura late in the aftemoon, and after a good night's sleep, were fully prepared for further visiting. Our next journey was to La Junta, the largest plantation in that district. Like all the others, the approach was through the forest. by the usual trail that meant considerable rough riding, the forling of streams. plorlding through mud, and climbing over fallen tree trunks. By this time I was fairly used to it, however, and was enjoying it as I never would have helieved possible. It was early in the afternoon when we emerged from the forest and struck the broad, fine road that rums through the plantation. We were now on a ridge that gave a fine view. not only of the rolling land covered with young rubber trees, but some two miles off we also saw the administration linilding and workmen's homes that mark the certer of the planting operations. The estate contains some five thonsand acres, of which about one-half is already cleared, most of it planted to rubber. The trees are from seven to nine feet apart. and looked as if they were in prime condition. The urchard numbers abrut seven hundred and fifty thousand rubber trees. The oldest were two vears and average 23.5 inches in diameter, a foot from the ground, and about seven feet in heiglit. For help, there are from two hundred to four hundred men, one-half of whom are natives. I'erlaps here more than anywhere else has been tried the experiment of importing: labor, and not dependling entirely npon the native. who is not at all times entirely reliable.

The average moso, or agricultural laborer. is, however, a most interesting study. If treated well, he is a good workman, and that, too, without any particular reason why he should be. In the community in which he lives, he has allotted to him a certain ansomt of land, which if tilled three months in the sear very moderately. will produce enough to keep its nwner in what is to him comfort, the year round. As a rule. the mozo is of merlinn height, strong and skilled within certain narrow 
linit-, but ignorant, superstitions, and chilllike. For instance, he can carry on his back almost as much as an able bolied burro, but if he were to reach with both hands up the branch of a tree over his hearl, he would find it impossible to pull his chin up even with it. On the other land, he can use his machete, his constant companion, in the most skillful nammer, and tirelessly. For example, he knows so thoronglyly the textnure and density of all tropical vegetation, that he can cut his way through the forest with scarcely a somm, gradling each blow so as to exactly sever vine, stalk, or limb, without waste of strength; or, if

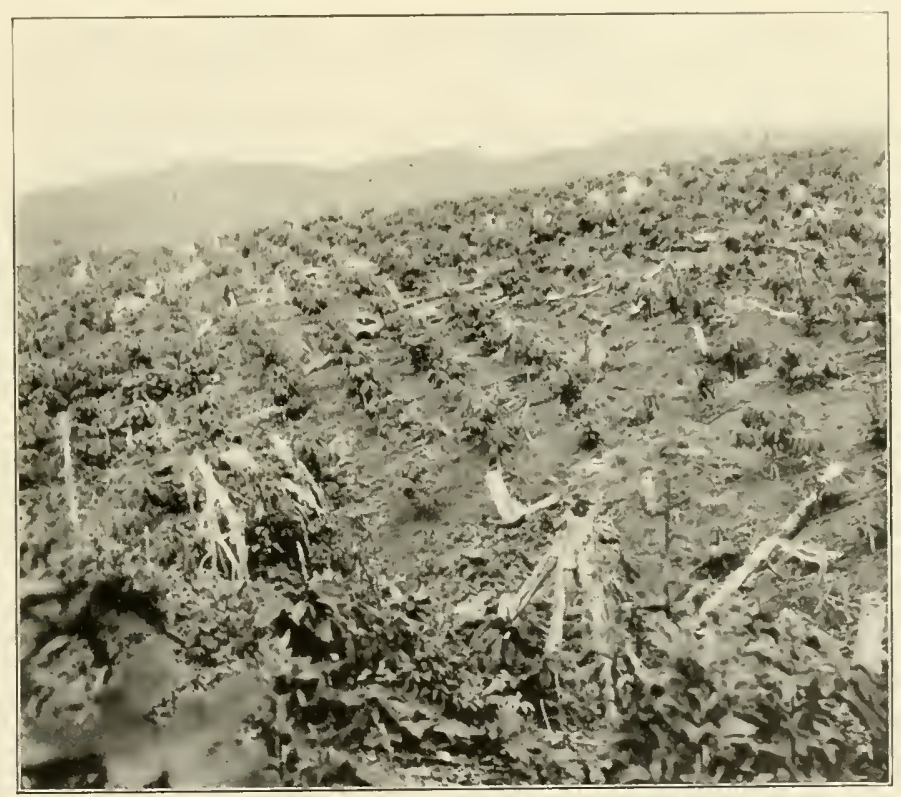

RUBIO.-YOUNG PLAN'TED RUBBER.

given a stint of work in clearing weeds or undergrowth with the machote, can do more in half a day than any other laborer can in a day. The axe men among them are not as common as the machete men, but they, too, are exceedingly skillful, wielding the straight handled, broad bladed axe with marvelous ease, and felling a tree, no matter how large it is, exactly where they wish.

As a rule, the natives are not well nourished, and seem to have more sickness than to the foreign residents. Indeed, the stories of yellow fever that come to us relate more to the native workman than to 
any other people. Strange as it may seem also, the workmen from the hill country, when they get down in the hot countries, are very apt to die of pneumonia. The mozo withal is an impractical sort of a chap, and while he knows it, he doesn't seem to care to change. I heard a planter point ont to one of them that if he stayed on his own allotment, and worked, he would in three months raise fifteen dollars worth of corn: on the other hand, if he worked three months for the planter, he would get sixty dollars and all the corn he wanted. The native acknowledged the force of the argument, but didn't see his way clear to change his habits. They are a very serious people, as a rule, except when full of aguardiente: then they become rather boastful, and are sometimes quarrelsome.

A pretty custom of the country is the greeting that they alwars give the traveler, and uswally each other when they meet. In the morning, it is "buenas dias": in the afternoon, "buenos tarde"; and in the evening, "bucnos noches."

The mozo is essentially a religious being, and his impulses find ample scope in the thirty-five fiestas, or feast days, that have been provided for him. He ustually patronizes at least two of these, and oftentimes many more, and spends every cent he has on aguardicnte and mescul. The result is that he gets conspicuously drunk and stays so as long as he can. Such a thing as a mozo having money ahead is unknown. On the contrary, he is msually in debt. The planters, therefore, when they hire them, purchase this debt, which sometimes rums as high as two hundred dollars, and also promise the man a certain advance to be spent at the next fiesta. The average wage is from sixty-two and one-half cents a day up to about seventy-five cents a day, and found. This, as a rule. includes three drinks of aguardicnte a day. Some of the planters have secured negroes direct from the United States, and from Jamaica. These get about seventy-five cents a day, and found, except when railroad contractors tempt them off by offering them from two dollars to five dollars a day. But to return to La Junta.

We rode for a long distance through the rubber, and finally, ascending a steep hill, found ourselves in the main street of the plantation village. Here was concentrated the life of the place, and the scene certainly was a lunsy one. Of the thirty or more native houses of bamboo and palm thatehed, several were rapidly being turned into frame dwellings with tiled roofs, and built to stay. Beyond these was the long, one story hotse of the general manager and his baker's dozen of active young American assistants. Then came the store, stocked with as 
large a varicty of goods as any village emporium eould loast, and then a two-story building. the lower part of which was the general dining lall, and the upper, the office of general manager and field superintendent. ()n the opposite sille of the street was the carpenter's and blacksmithis shop, the stables, ets.

The active head of affairs. Mr. (ieorge Mann, caught sight of us almost as soon as we arrived, and mot only batle us to supper, but insisted that we stay over night. This we decided to do, rather than to ride the trail after nightfall. He then introduced us to his staff, or such of them as were not absent, and Messrs. Kraner. Hill, Zimmerman, Shufeldt. Sleister, and Dr. Erwin, all young, active, and friendly, together with their capable chief. will long linger in my memory as types of

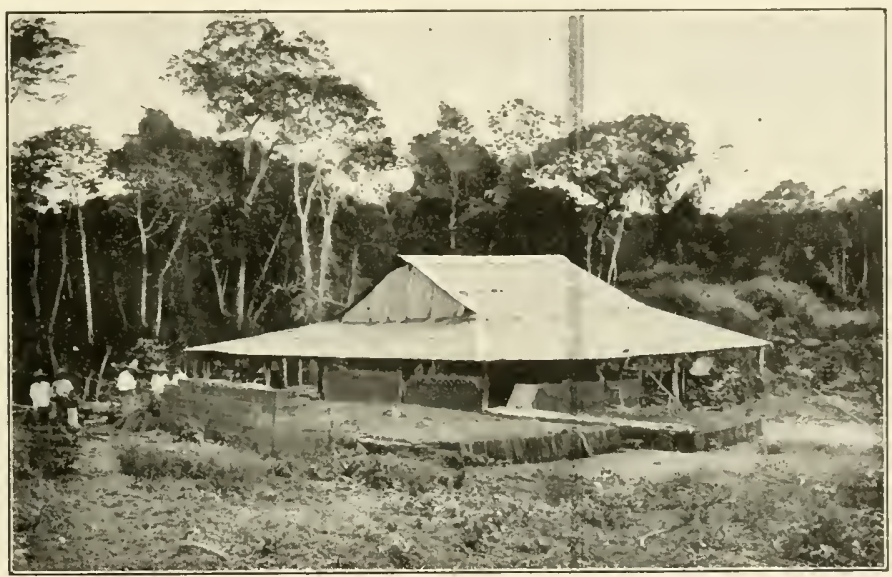

RUBIO, - BRICK ANU TILE FACTORY.

Americans that are so effectually conquering the tropical wilderness. 1)r. Erwin by the way, is physician and surgeon for the plantation, and Mr. Shufeldt is the son of Commodore Shufeldt of the Lnited States Nary, who survered the route for the Tehuantepec ship canal for the Lnited states govermment, some years ago. Mr. Sleister I larl alread! met, as he was on the train that bore me to Achotal. I dicl not see much of him. however, as he had a carload of Tennessee negroes in charge to deliver to La Junta: and as one or two of them were "bad coons," and as liquor was abundant at every stopping place. his hands were full most of the time. By the exercise of much patience and tact. and by wearing a luge Mauser revolver while in their company. he finally got them all safely there. 
There was still enough of daylight to have a look around, so we visited the varions shops, the sawmill, brickyard and waterworks: inspected the native quarters, and got back just as supper was announced. We spent the evening in the assembly room of the officers, smoking big, black Mexican cigars that have no harmful effect in that climate, but would be deadly in the north, and listening to home music from a well equipped phonograph.

W'e retired about eleven, and had hardly gotten a good grip on our beauty sleep when a stir outside showed that something was doing. Not to miss anything. I went out upon the broad verandah, and found the young men saddling their horses, and equipping themselves for a moonlight ride. Seeing me expectant, they informed me that nine of the Temnessee negroes had skipped, doubtless to join some railroad gang, and for a short time get higher wages. As the company had paicl their fare from the States to the plantation, and as the moral effect on the others would be bad if they were not brought back, it behooved those in charge to stop the runaways before they reached the railroad. And they certainly went about the matter as if they meant business. It was a thrilling sight to see them assembling, and I forgot that I was pajama clad and barefooted, and stood in the moonlight watching until they finally cantered off down through the valley and over the hills, and were lost to sight in the black wall of forest, into which the road ran. To finish this incident, I may add that they overtook all of the runaways, and brought them back, and they went to work again just as if nothing had happened.

The next morning after inspecting the rubber, and getting samples of earth for analysis, we took the road home, where we arrived safe, sound, and happy except for the rodadors and pinoleos.

Plant life in Mexico seems to be exceptionally free from pests of all sorts. I did, in the course of my trip, see three caterpillar nests, but not in the Ticrra Caliente. I looked and inquired particularly for any enemy of the Castilloa, but found trace of none, and heard only of an ant that attacks the tree where it has been wounded at times, but that only rarely. Of the few trees thus attacked, nearly all had thrown out woody excrescences that were not only protecting the inner tissues, but seemed actually to be crowding the devourers ont. So rare is it that a tree is thus attacked that the planters take no precantion against it.

Speaking of ants, these busy workers are in evidence nearly everywhere, and when the "marching ants" come in force, everything that 
can gets ont of the way. The houscholders welcome these visits, as the ant army goes through every crack and cranny in the house, killing mice, spiders, and insects of all sorts; in fact, making a clean sweep. When they call in the midlle of the night, and announce their arrival by nounting one's bed, and by the most vicious of bites. it is a bit sudken, but all one lias to do is to get out of the way until their work is done, when they depart with the curious rustling noise with which they came. Some of these armies march great distances, and have huge nests, as much as fifty feet in diameter.

The rubber tree is not singular in being free from pests-nearly. all others seem to be equally so. It was a rare thing to see a leaf or a petal that had been blighted or eaten by any sort of insect. The reasons for this remarkable immunity from the usual pests are not far to seek. They will, I think, be found in the great abundance of birds, and no doubt in the wonderful equilibrium that nature has there established between the insects that are destructive to plant life, and the other insects that prey upon them. It is to be hoped that this balance may long be preserved. As a matter of caution, it might be well to state that the hunter who slaighters birds for their plumage will not find a cordial welcome among the Mexican planters.

In the drr season, which of course was when my visit was made. there are but few butterflies and moths but in the rainy season they are most abundant. Of these my host had a collection which gave me a wonderful insight into the winged beanties of that section. 


\title{
THIRD LETTER.
}

\begin{abstract}
Clearing and burning by Contract-Danger from Fires-Gathering Castillod Seed-Testing Seej-Costly Seed Fiilures-Track Walking Under Difficllties-The "Boston Rubber Tree"-Morning Glory Vines-Arrival at Santa Lucretia-A Condensed Mrle Lesson-Contzaconlcos-Sleeping in the "Birf Cage"-Up the Usapanapa ani Chichigapa Rivers-Plantation "Rubio"-A Fine "Bodega"-On Horseback Through Miles of Rubber-The T.apPing Problem.
\end{abstract}

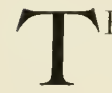

HE planters in the Trinidad River district were so well informed, and so ready to impart their knowledge to one interested, that I felt as we journeyed back to La Buena Ventura that I was getting a pretty good grasp on the rubber planting situation. I had learned, too, specifically, what clearing, hurning, planting, lining. staking, and cleaning involved. Indeed, as luck would have it, I ran across some of the men who take the contracts for cleaning, at various times during my journey. In certain cases the planters clear their own land. They prefer, however, to let it out by contract, as it does not cost so much, and is one less burden for them to bear. In Vera Cruz, clearing is usually done between the middle of February and the last of Ipril. The contractor brings a large force of men who fell everything. the axemen handling the big trees, and the many machete men lopping branches, cutting vines, and arranging all for a good burn. If the work is well done, and at the right time, the mass of fallen litter gets at least a month of hot, dry weather, which dries ont the fallen timber almost berond belief, and gives weeds and climbers no chance to spring up. This part of the work is very important, becanse if a poor burn takes place, it involves the cutting and piling up of half burned tree trunks. and a second buning, which is costly. It is figured that in this work twenty-five men will clear about half an acre a day.

During the burning the planters are always on the watch to keep the fire from sprealling, not nnly into the virgin forest, but into adjacent plantings. The danger from fires carried by subterranean ronts which may smoulder for days, and then burst into flame, is no slight one. Indeed, several cases have necurred where the fire has spread into cleared lant, and destroged many hundreds of valualle rulber trees. To cite one case in point, it might be well to recall the loss of the Varney Rulber (o). who harl a plantation on the Tehuantepec kailway, and who lost 
two hundred and fifty acres of two-year-old trees ly fire in the dry season, said to have leeen started hy sparks from a locomotive.

After the burn is finished, the groumd is open and spongy, and in just the right condition for the reception of secel. If this seed is put in so as to catch the early rain, it gets a wood start before the torrential rains come, when the soil is pounderl down hard. This is the reason that seed planting the second year is not apt to prosper, and why it is better then to transplant from a well equipped mursery. The earliest bloom of the Castilloa appears about the first of March, the seed ripening within sixty days, and it is usually all gone thirty days later. The seeds are

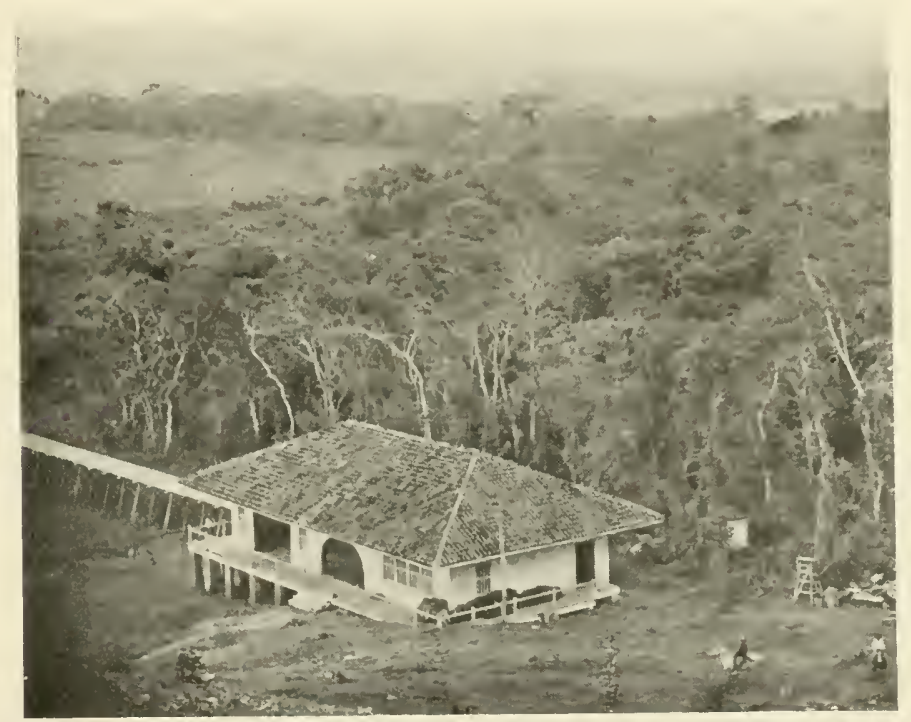

BODEG.I ON PLANT.ITION RLIIO.

wathered, as a general thing, as soon as ripe. and it is often a race hetween the planters and parrots to see which will get the most, as the latter are very fond of them. The seed is secured by knocking the cones off the branches of the trees with long poles. These cones are put in water, and allowed to stand over night, when the gluten surromuling the seed slightly ferments. The mass is then placed in a sieve, and the pulp is easily washed away. After a fual washing, the floaters or muitalized seeds are skimmed off. and the residne are dried on mats in the shade. As the vitality of the Castillou seed is very slight, it is necessary to plant 
within a week or two at the longest. It might be well to note here that Mr. Harvey kept some seeds alive by packing in charcoal, and that they germinated when planted several months later, but no one but a trained horticulturist would be likely to be successful with such an experiment. With regard to the planting of the seed, it should be remembered that the first rains are oftentimes followed by a week or two of dry weather. It is therefore best to wait until at least four inches of rain have fallen, that is, when planting in heary soil, and to have a reserve of seed saved for failures, either from drought, washouts, or lack of germination.

On one of the plantations I was shown the result of a very interesting experiment, which was designed to show why, of two seeds, planted near each other in apparently equally favorable positions, one produced a vigorous tree, while the other produced a weakling. To determine this, the planter selected three sizes of seeds and planted them under equal conditions, supposing naturally that the largest seed would produce the most vigorous plant. He learned, however, that size had nothing to do with it, as in some cases the smallest seeds produced gave the best result. The real difference seems to be, therefore, in the inherent vitality of the seed itself. There are a great many ideas regarding the best way of planting the Castilloa, and there is no doubt but that different methods are adapted for difference of situations. I am firmly convinced, however, that, in the region I visited, by far the best method of planting is at the stake, backed up by a small nursery, in order that the failures may be made good. Any one who has seen two-year-old seedlings as against two-year-old nursery plants will, I think, agree with me.

Again and again was it impressed upon me how alert and careful the planter must be in preparing his ground, and especially in getting his seed at the right time, and getting it into the ground so that it shall have the proper start. And their knowledge has come through acknowledged failures. One good friend of mine bought a ton of seed at one dollar a pound, and was unlucky enough to have it all spoil. Another cleared hundreds of acres for which he failed to get any seed, the clearing having to lie over until the year following. And these are but two of many instances which would discourage any lout the most determined men. Put such happenings do not reach the same man twice.

On our arrival at La buena lentura, mine host found a letter from a large planter down near Coatzacoalcos, inviting him to visit his place, and as that was just the direction in which I had planned to go, I resolved to embrace the chance to go with the hest of guides. It therefore happened that early morning found us in the saddle, butnd 


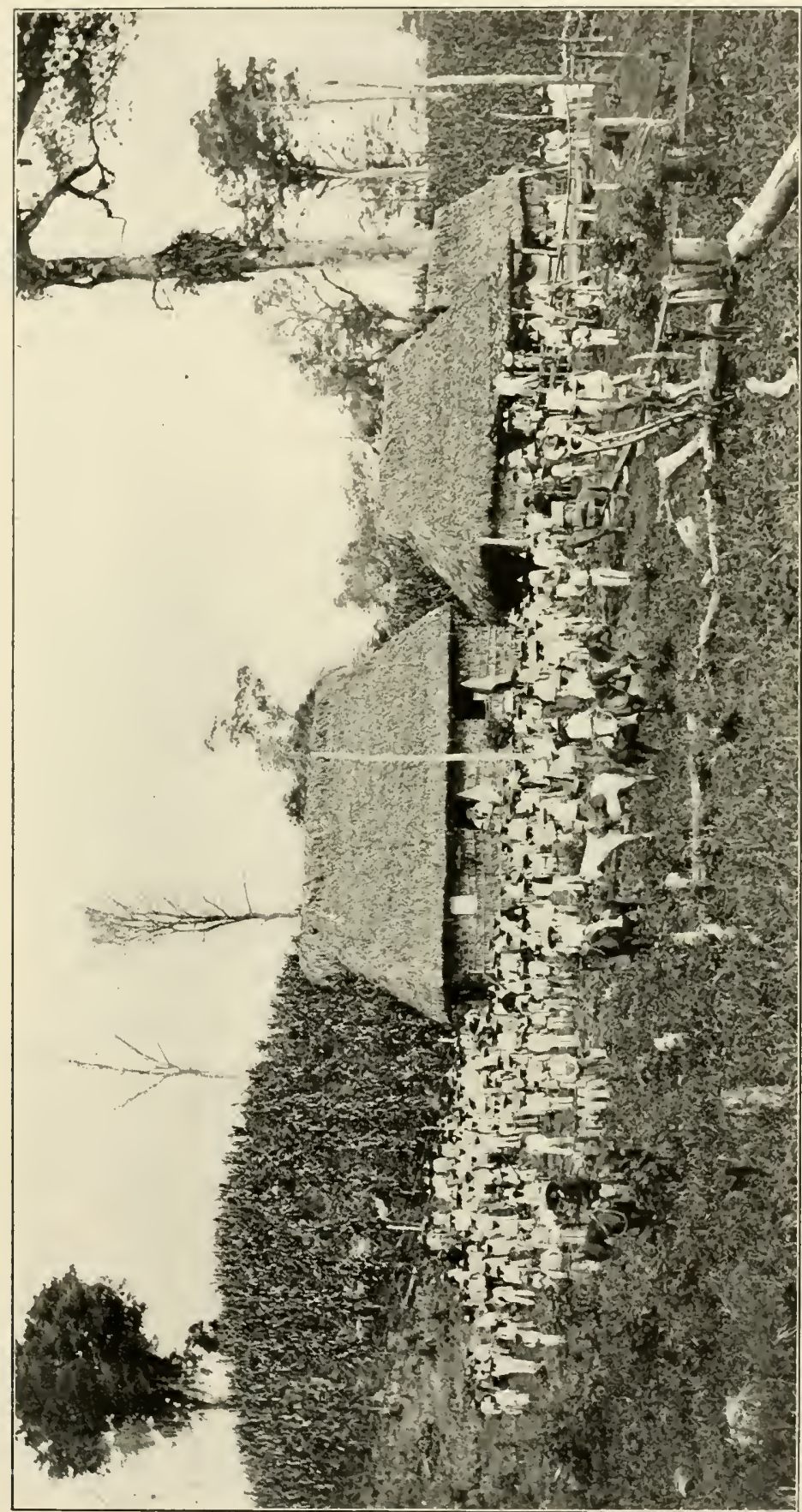

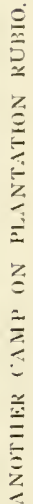


for Santa Rosa, but not over the trail hy which I had come in. This time it was over a clear path, through the planted rubber trees, dipping down into the forest, and over a road with a soft carpet of matted leaves two or three feet deep, and as springy as if made of rubber-a new trail. and all on La Buena Ventura land. On reaching the railroad, we sent the horses back, and after waiting awhile, hoping for a train which might or might not run that day, we started to walk towards Santa Lucretia, where the new road joins the National Tehuantepee Railroad. Walking a railroad track under any circumstances is hard work. but that track was certainly not made for tramps or actors. It had been hastily laid in the rainy season so as to make connection at Santa Lucretia, and infreguent and slow though the trains were, it was already a godsend to the planters and travelers. Ne knew, also, that as soon as the dry season came it would be straightened, ballasted, and put in shape. But its prospective virtues did not make the walking any easier. It was not altogether because the sleepers were laid at meven distances, and often not spiked to the rails, or that the grass had grown up and covered both with a slippery tangle, nor was it the clayey muel that often rose flush with the rail tops. but it was the combination of all these that tired us out ere we had gone very far. Still, we had no thought of backing ont. and so plodded steadily on, our packs on our shoulders, our feet clogged with mud, and wondering if lnck would send the construction train to our assistance. But the trip was not without its compensations. The day was gorgeons, and my companion, botanist and enthusiast as he is, talked of the trees and plants in a way that would make one forget any sort of hardship.

Speaking of the forest, one of the most conspicuous trees is a sort of a banyan, which has all the idiosyncrasies of that tree of many trunks. and grows to a great size. It is a species of Ficus which has not as ret been identified, but is probably the Ficus Bcnjamina. On tapping it gives a certain amount of latex. but of a very sticky nature. and prolubly of no value. There are also a great many malogany trees, but in the former lumbering operations the larger of them lave been cut out, and while there are nuny of them that wonld square perhaps twelve or fonrteen inches, there are not so many which would go 11) to eighteen inches, the old time test. Howerer, mahogany is so plentiful that many of the bridges across the streams on the forest trails are marle of squared mahogany logs, one or two of them laid sicle by sicle, and malogany furniture is very common in the planters home furnishings. There is considerable ligmmm ritc, and on the track we 
were then walking it was often used for ties. Spanish ecelar is also yuite abundant, and is one of the valuable woorls.

In resard to trees the old resident, and sometines the semi-old one, is very apt to point out the rubber tree in its natural state as you ride with him through the forest, and if he knows anything alout rubber, he never makes any mistake. If he doesn t, he is rery apt to point out a tree which the planters call the "Boston rubber tree," and which the natives call the "chankarro." It really looks like the Custillou, but is apt to prove a surprise to those who try to tap it. The trunk is only a hollow shell, and the interior is invariably filled with what are known as the fire ants, of whose presence the tapper is instantly apprised when his machete cuts through the thin film of bark.

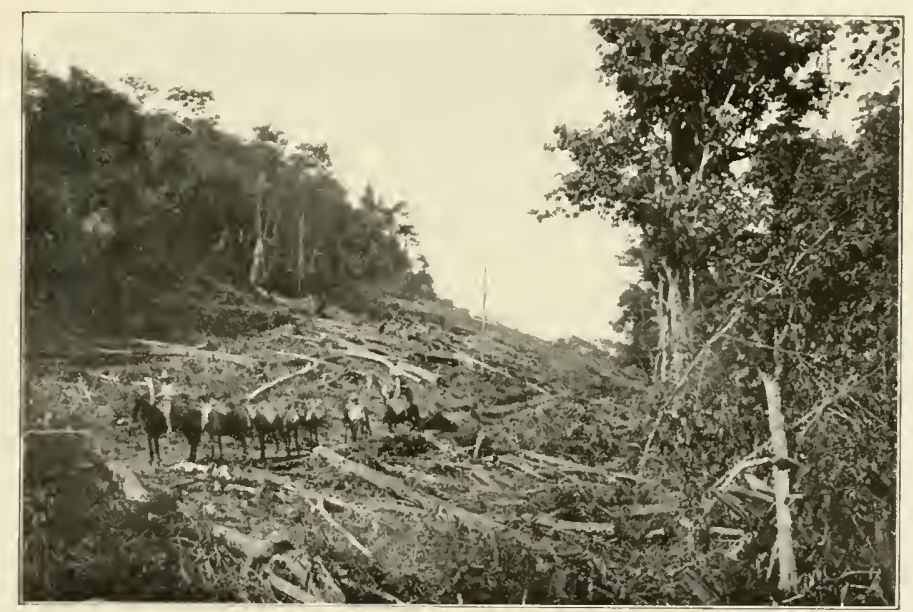

PIECE OF ROAD ON PLANTATION RULIO.

There are, also, many beautiful trees, such as the "roval" and other paims, and an infinite variety of rines and climbers. Perhaps the most abundant vine down in that part of the comtry is the morning glory. which is not an annual as it is with us, but it is a perennial, and swarms up over the tree trunks, covering acres of forest with its dense foliage. and its beautiful bloom. To those who insist that the trunk of a rubber tree should not be exposed to the sum. I would suggest that they allow the morning glory vines to cover it, as they will shade it perfectly, and do the tree no harm. At the same time. I an personally convinced that the tree needs no such shading.

I must not forget one vine that we noted on our journey, as it 
had a blossom that for size put in the shade anything that I had ever seen. I do not recall the botanical name, but it is of the family that produces what is known as the "Dutchman's pipe." We saw several of them, and finally secured a blosson. In size it was as large as an old fashioned Shaker bonnet, and must have weighed a pound and a half. It was not pretty, except in a bizarre tropical sense, but was simply a type of what the richest of soil, plenty of moisture, and constant warmth can produce.

There seem to be few poisonous plants: the most common is a luxuriant shrub with a crown of handsome white flowers, which acts like a gigantic nettle, instantly paralyzing the hand that grasps it. This is very plentiful, and its Spanish name means "the evil woman plant."

None of the forest through which we passed would be called primeval as there were no trees that were over one hundred and fifty years old. Just why this is so, none can tell, but that the land was once densely inhabited is proved by bits of pottery, arrow hearls, etc., that are to be found on every plantation, and in the railroad cuttings in great abundance. And that reminds me that at La Junta Mr. Shufeldt gave me a hicleously interesting little clay iclol which he found in a vegetable garden there. I nnwittingly left it on the table in nuy room at La Buena Ventura, and I wish to warn the genial householder that I an coming down soon purposely to recover it.

Meanwhile, hot, perspiring but cheerful, we were plodding on towards the Tehuantepec Railway that was miles and miles in the distance. Finally, however, we reached Sanborn, soon to be a metropolis: but when we arrived it was simply a camp where men were grading, felling. the forest, and getting ready to put up a modern railway station, which is to have a telegraph and telephone office, and all sorts of modern conveniences. This place, by the way, is about eight miles from La Junta, and will be its railway station. It is named after one of the prominent officials, who, besicles his interest in rubber planting. has purchased a big block of land, and is going into lumbering. brick making, and a variety of industries that will be of marked benefit to that section. At Sanborn we struck good luck, for we had not been there five minutes when a locomotive whistled, and soon the construction train crawled into sight. We boarded the flat car in front to keep from being set afire by sparks from the wool burning engine, and we continned our journey:

Arriving at Santa Lucretia in due time, we disembarked and wended onr way to the town proper which consists of a hotel on stilts, 
a railway station, and a few native huts as a background. With a railway camp close by, and with the many Americans constantly going and conning, the town really presented a busy scene. The hotel is run by Major Elliott, a powerful man with a military learing, very friendly to those who behave, lut a trifle stern with the semi-worthless natives that are ever to be foumd at a railroad end. We had an excellent dinner.

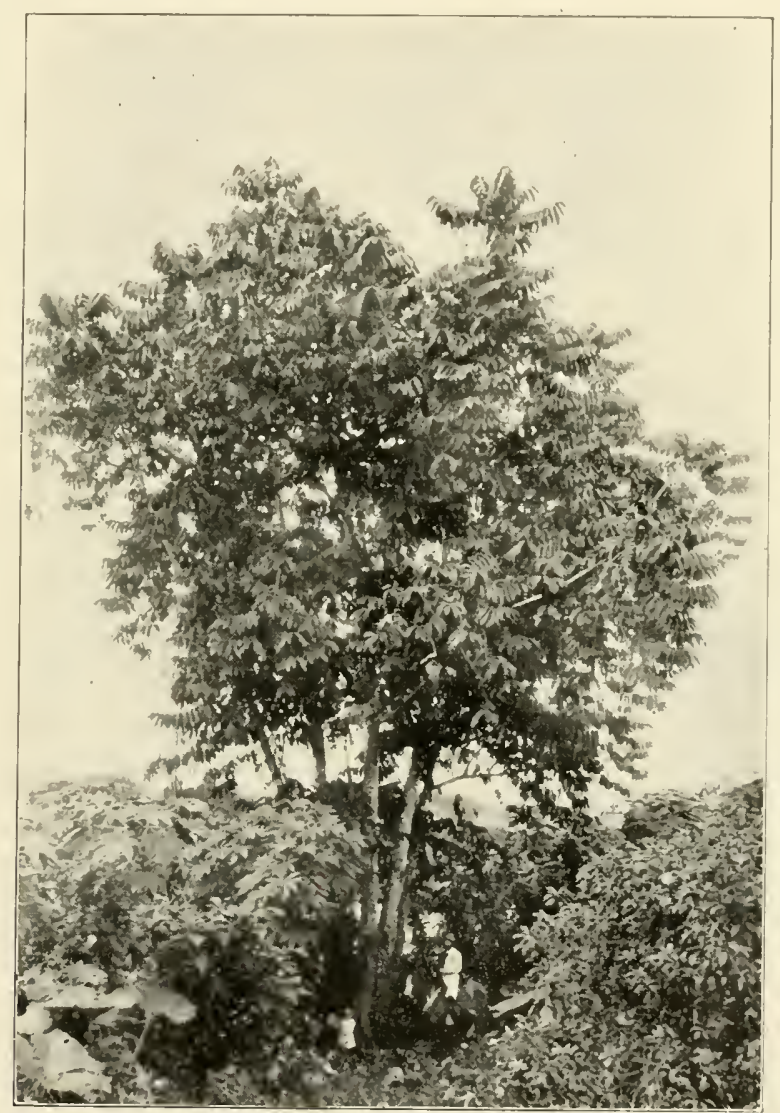

WILD RUBBER TREE ON COATZACOALCOS RIYER.

partly of native food, and partly canned goods from the States. Speaking of the latter, American manufacturers do not seem to realize that one of the best supply markets in the world is to be found among the planters and small hotel men in the tropics. Some do, of course, and some of the great merchants and mail order houses are cultivating the 
field most industriously and profitably, but most do not. A case in point, of this lack of appreciation came to my attention during this journey. A planter who is so thoroughly American that he would far rather buy of his own countrymen than of any other, used a great deal of condensed milk. That which he bought of English or Swiss make was white and sweet, while the American brand that he wanted to buy soon became in that hot, moist climate, of a chocolate brown color, and quite offensive. In the goodness of his heart he wrote the manufacturers, telling them the whole story, and instead of being thanked, received a most insulting letter from an officer of the company. He wrote again, not in his former vein, but stating a few salient facts, and ended by remarking that as the English had for one hundred and fifty years been successfully supplying tropical markets, they would probably keep on until Americans had the sense to study their methods.

Just before the train arrived, our party was reinforced by the arrival of Mr. R. O. Price, the general manager of Solo Suchil, who had been apprised to be on the lookont for us, and who told us that a steam launch would be waiting for us at the end of the railway journey, to take us up the Coatzacoalos River to Minatitlan. and later to the plantations on that and tributary streams. At length our train came. and we were on our way. The much vaunted National Tehauntepec road is no doulst an engineering triumph, but what with earthquakes. morasses, and streans that are one day rivulets and the next raging torrents, it is not yet equal in equipment or service to a one horse road in the Far West. The trains run every other day, and get in on time very rarely.

We finally arrived at Coatzacoalcos, the Atlantic terminus, two hours late, and there were welcomed by Mr. A. B. Luther, the gerante gencral of Plantacion Rubio. Here two more Americans joined the party, and boarding the steam launch, we steamed up to Minatitlan, a quaint old Mexican town where we were to spend the night. Beds had been bespoken in the little hotel familiarly known as the "bird cage." and we were soon sleeping the sleep of the just.

With the first break of day we were up, had our coffee, and starter out to see the place. Is a matter of fact, there was not much to interest one at that early hour. Most of the inhahitants were still wrapped in the warm arms of the sleep god, whatever his Aztee name may he, and the chief signs of life were the dogs, chickens, and turkey huzzards, the latter the most independent and loathsone of all the feathered tribe. There is a fine of fifty (lollars for killing one, and the creature knowing 
this pursues its scavenging operations with a ruffianly impurlence that is disgusting. It is said that every community in those parts has one huzzard for every inhabitant. According to that, Minatitlan has lots of folks that do not appear in public, for seated on fences. on roofs. swooping down to rol, the dogs, fighting, flapping. and squawking, the buzzards were legion.

A little later we all assembled at the boat landing. climbed over a lot of Indian dugouts, and were prepared for the trip up river. ()ur journey that day was to be np the Coatzacoalcos, the Usapanapa, and Chichigapa Rivers, some twenty miles, to visit plantation Rubio. IV

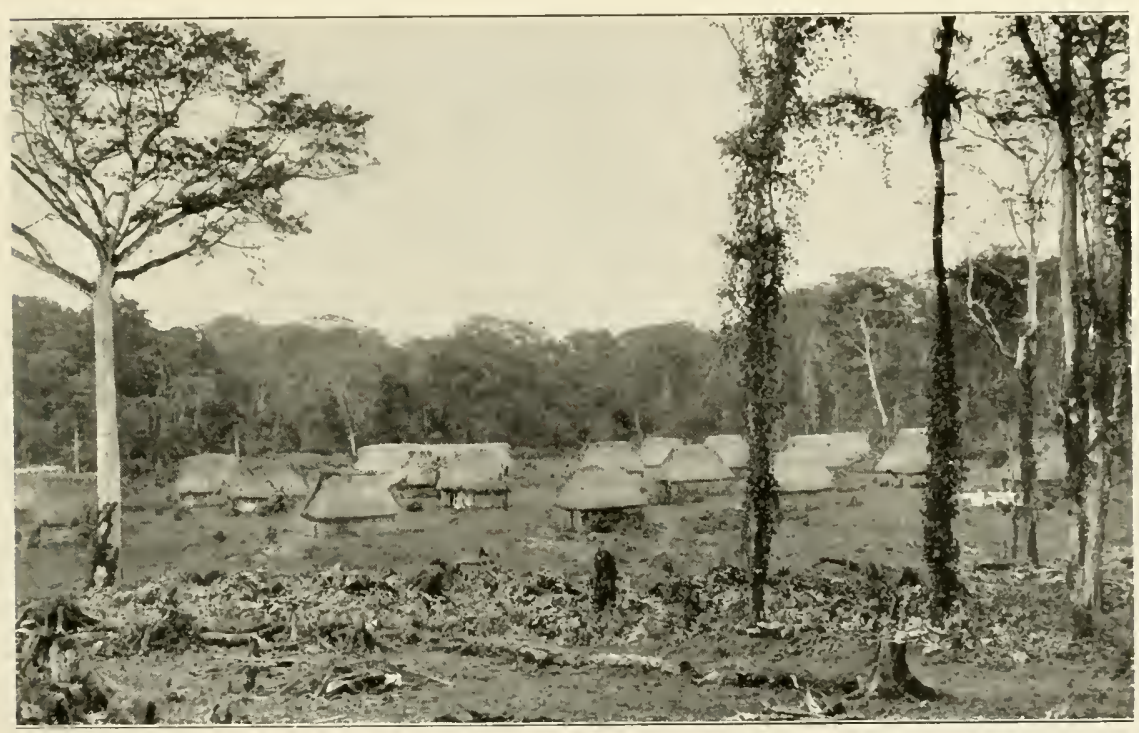

THATCHED VILLAGE ON THE UBERO PLANTATION.

had elected to talk a lot about rubber planting. but the strange sights. the wonderful scenery, and the glory of the day drove all thought of "shop" out of our minds. Pý tangled forests, great. grassy plains. Indian villages, and bamboo thickets, we went, disturbing sullen alligators, and great milk white cranes, and being hailed in unknown tongues by the naked children on the river banks.

When the novelty of the scene had in a measure worn off. I availed myself of my privilege of asking questions, selecting the general manager of the Solo Suchil as mỵ first victim. He responded most cor- 
dially, and I soon learned that his plantation was an amalgannation of three estates: that it was named after the river on which it was situated, and grew both coffee and rubber, the latter being used for shacle. He had planted both from seed and from nursery stock but favored the former when practicable. His trees were from one to five years old, and there were about four hundred thonsand of thems. He, like all others, was of the opinion that it was fatal to allow the grass to get a foothold among the rubber trees. For this reason, when the rubber was planted alone, it was put in from seven to nine feet apart, and as a further precaution he was planting betweeen the rows a kind of sweet potato known as the "cannate," which covered the ground with a dense mat of vines among which the grass would not grow. This brought ont the store of practical botanical knowledge of my friend, Harvey, who recommended the cow pea and the velvet bean for just this purpose, an opinion that I found shared by the others, notably Dr. IV. S. Cockrell, another pioneer planter.

After a two hours ride we turned into Chichigapa Creek, a deep, silent waterway about two hundred feet wide, and ere long we were tied up at the wharf that is part of the Rubio estate. As the banks are low, a substantial platform sone six hundred feet long leads back to the bodega, or storehouse. This is a two-story building of brick with tiled roof on one side and glass roof on the other, and is sonething that every planter should have. It is, in fact, a dry house for corn and beans, and is fitted with air tight bins for the storage of these cereals, an effective protection against the omnipresent weevil and equally troublesome mold.

The building that challenged our admiration for its beauty, however, and later for its manifest utility, was the two-story dormitory that situated on an eminence further back, looked like a planter's mansion. On close inspection it was found to contain a dining roon and kitchen, and sixteen sleeping rooms, all of which opened ont on to a broad verandah, which was wholly enclosed in wire netting. The partitions between the rooms were made of burlap. painted over to give it a finish. a very practical and economical plan in a country where matched boards bring a high preminm.

To view the plantation proper, it was necessary to have recourse to the horse, and after lunch quite a party of us started through the typical forest trail towards the cleared and planted lancl at the further sirle of the estate. At length we energed into the open and found ourselves on a ridge from which we had a view of hundreds of acres of 
rich, rolling land, all covered with Castilloa trees about a year old. Ile rode over this whole planting, visited the fonr camps where the native workmen live in palm thatcher houses, and examined the rubber trees on the hilltops, on side hills, and in the valleys, and when we were tolsl that the stand of rubber embraced fifteen hundred acres, all clearerl, burned, and planted in one short season, and that there were fully two million healthy trees, we fell to congratulating Manager Luther on the accomplishment of so marvelons a task. It took so long to do the whole of the sightseeing that it was lark when we entered the forest again for our two or three-mile return ride. Our horses knew the way, bowerer, and brought us safely through, and an hour later we were on the launch, steaning back to Minatitlan. The royage was without special incident. unless one were to cite the clouds of white moths that filled the air until

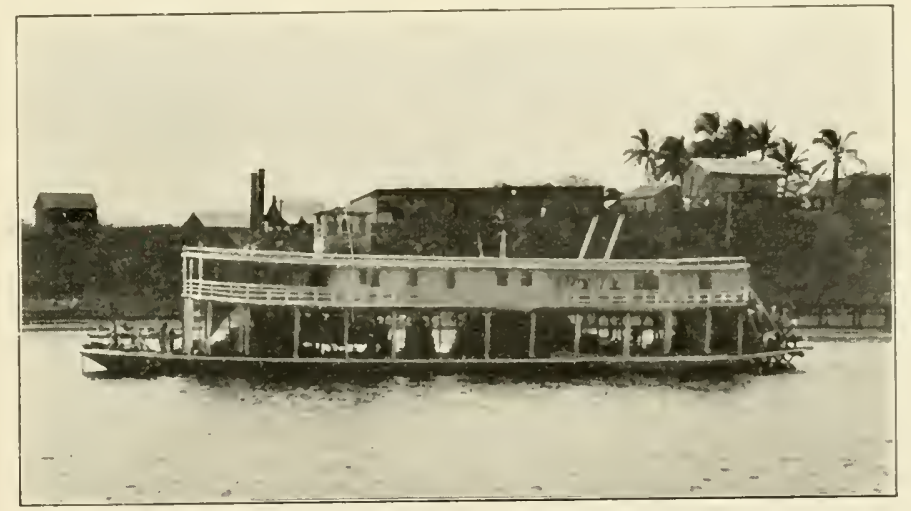

STEAMER "DOS RIOS" ON THE COATZACOALCOS.

it looked as if it were snowing, and which finally drove us to cover in the cabin.

The next day we took in a plantation far up the Coachapa River. owned by a wealthy native. Señor Sanchez. His interests were chiefly in cattle, although he had a little grove of wild seedling Custilloas about ten years old, which were from sixteen to eighteen inches in diameter, and perhaps thirty feet high. These we tapped in all sorts of ways. got an abundance of milk, and incidentally proved that neither native nor white man can tap a tree successfully without much practice and skill.

Indeed, the next great problem that is to contront the rubber planters is that of tapping and preparing for market. One has only to look at the wild trees in the forest and see how they have been hacked 
and scarred by the natives, to appreciate the fact that the planters will need better work and greater care of their trees. If all of the natives were expert machete men, and good climbers, the problem would be easily solved, but the real good men in this line are scarce. It is a most interesting sight to see a skillful tapper, armed only with a rope and machete, cut the channels so that the sap runs from one to another with scarcely a drop spilled, every stroke of the machete being just right. It is also equally disgusting to see a native who claims he knows how to tap nangle the bark, and able to climb only a foot or two without slipping down. The practical solution is going to involve two things: one is, the invention of a simple tool that is foolproof. and that cannot in any way injure the tree, and the second is a light, safe ladder that will allow

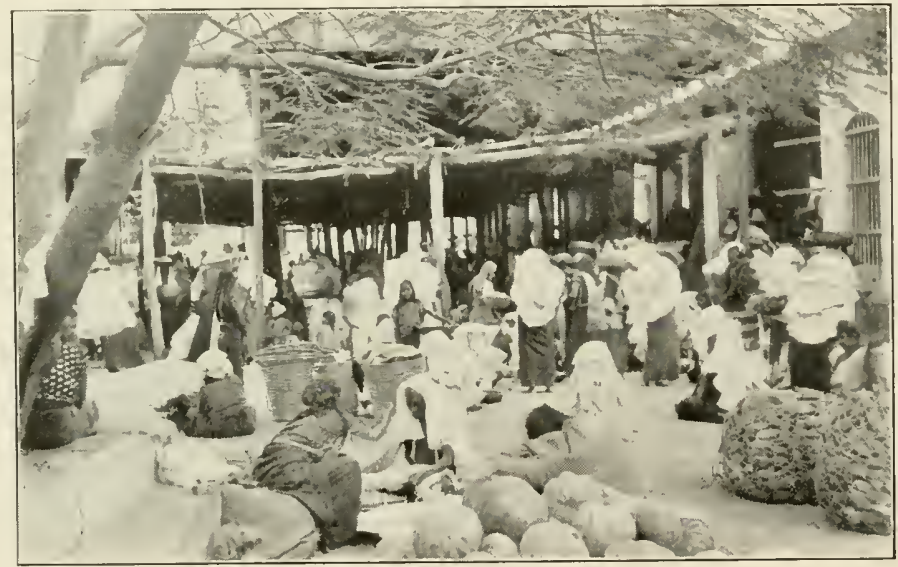

THE TEHUANTEPEC MARKET.

the moso to reach the upper part of the trunk. Most of the planters plan to bleed the trees twice a year, in Nay and October. Some, however, hold that they can stand tapping much oftener, and most interesting experiments are being inaugurated in the exploitation of this theory.

The latc. flows apparently as freely at one time of the year as it does another, but the dry season is undoubtedly the best for tapping, as there is 110 rain to wash away the nilk, and the tree is resting then. If the cutting is done well, the scars soon fill in with new, smooth bark, which in 110 way interferes with later working. The natural way, however, will be to drain one side of the tree at one time, and another at a subsequent tappins. The planters are ailrearly planning as to the 
arrangenents of gangs of men, and the pay for tapping and coagulating. The favorite method undoubtedly will be to give each native a certain stint, measured ly the amount of late that he brings in. I got a mumber of estimates as to the cost of tapping and congulating, based on actual work, and in no case was it more than ten cents a pound, Mexican. - Inother thing that the planters plan to do is to produce clean, dry rubber, and there is no reason why they should not accomplish it. Of the various means of coagulating that are devised by experts, the one that seems to appeal the most strongly to the practical planter on the Isthmus, is the use of the juice of the "amole" vine, the I pomoea Bona no.x, which is most ahundant everywhere, and which apparently adols nothing to the rubber, and effects a quick and clean coagulation.

Ifter coffee at the Sanchez abode. we returned to Minatitlan, retired early and at three o'clock the next moming were awakened by Mr. Luther, escorted to the launch, bidden a hearty good-lye and were on our way to Coatzacoalcos, to take the morning train for Tehuantepec. We had planned to take a river steamer, the Dos Rios, and visit the plantations far up the river, of which there are a lot, but a snag having punched a hole in the boat's botton, it was forced to tie up for repairs. thus disarranging our plans. We therefore decided to go at once to the Pacific side, and "dry out" and rest, and so it happened that at nine in the morning we were again on the train, this time bound west. 
FOLRTH LETTER.

Across the isthulus-Plantation "San Francisco"-View of the "Ubero" and "La Crosse" Plantations-The Great Tehuantepec Plain-At the El Globo-Attacked by a Vanpire-The Zipotaco Wonen-Degs and FleasSalina Cruz-Back to Santa Lucretia-Mexican Justice-Sleeping Under Difficulties-A Night at a Railrodd Camp-A Tapir Hunt-The Persistent "Pinoleo"-Achotal Again-Journeying North-Cattle Ranching-TaxesCordoba and Orizaba-Mexico City-A look Backilard-The Coll Pea and Velvet Bean.

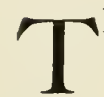

HE last letter of this series left us just boarding the train at Coatzacoalos for the joumey across the Isthunus to the City of Tehunantepec. The journey did not take the whole of the month that has intervened, but it took long enongh in all conscience, yet it was not without interest. Almost at once I struck up an acquaintance with a German, named De Verts, who, I soon learned, owned the plantation San Francisco up in the Dos Rios region. His plantings were of coffee and Castilloa. and of the latter he had some sixty thonsand trees two and one-half years old. These were planted seren and one-half feet apart one way, and fifteen feet apart the other, with coffee between. His trees averaged about eight inches in dianeter. From his description the stand appeared to be an excellent one.

After his departure a friend promised to point ont to me a man, who more than any other down that way, was making "easy money"none other than a traveling dentist who finds his patients only amons the natives. He goes from village to village doing a rushing business at great profit. It is said that many who have no trouble at all with their teeth have them filled in order to show the gold, and that they never weary of grinning. with that end in view. I did not see the dentist, for at this juncture we stopped at a station, where on a siding was a private car, on the platform of which stood Sir S. Weetman Pearson, the famous English constructor of tropical railroads. We all wanted a sight of him, and were rewarded by a brief view of a thick set. determined looking Britisher, who had an air of meaning business all the time. He was said to be discharging men right and left, and generally upsetting the policy of procrastination and inefficiency that had been more or less characteristic of the management in the past.

The National Tehuantepec Railroad is without doubt of great 


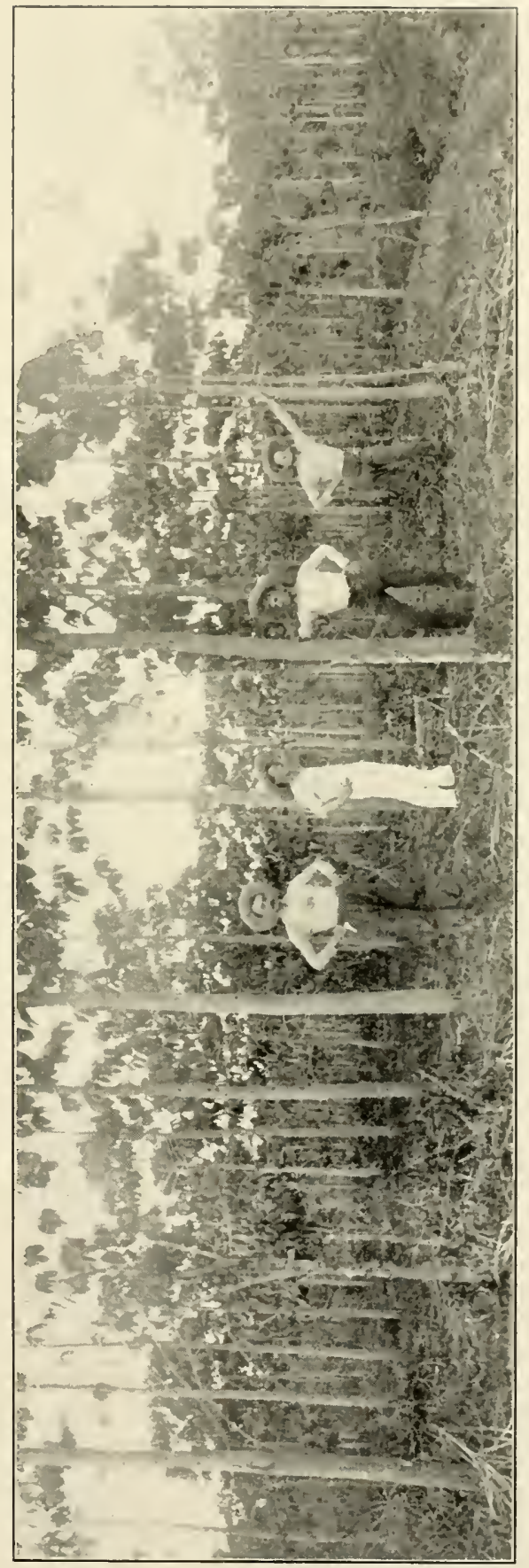

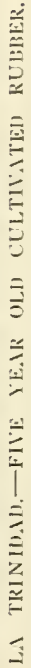


present and prospective value, both to the planters and to the owners. Its trains, which run every other day, are always well patronized, and it is wonderful how those children of nature, the Indians, enjoy crowding into the third class cars, and riding even a few miles. Many of the poorer ones save money for months, ride fifty or a hundred miles, and contentedly walk back. To them the trains are "flyers," and the cars palatial, but to the white man the many delays, particularly at stations, are very irritating. A resident of the country accounted for the long waits by stating that an engineer is paid two dollars an hour, and therefore the longer the run, the more he gets. He further intimated that if the train got on too fast, steam was allowed to get low, or some of the machinery suddenly needed repairs, for which a stop was necessary -but the narrator may have been yarning.

Shortly after noon we passed the handsome plantation house of the Boston Ubero Company, and had a good view of the many acres of pineapples that they have under cultivation. WTe also had a good view of the land of the Isthmus Rubber Co., a little later, and still further on was the La Crosse Plantation Company, which showed many acres planted to sugar cane, and considerable rubber.

Early in the afternoon we passed over the low momntainous rirlge that separates the Atlantic side from the Pacific, and left behind the hot, moist atmosphere that had become somewhat trying. and were in a climate bone dry, and seemingly much cooler. We then had a fine view of Rincon Antonio, the new railroad town that is rapidly assuming shape, and that will give to the workers in the shops a fine, healthy climate instead of a fever ridilen one.

Continuing our journey, we next came to the valley of the San Geronimo, healthy, cool, free from epirlemics, and a little later to the vast Tehamntepec plain. Here are more than a million acres of rich land as level as a billiard table, covered with a sparse growth of chapparel, and awaiting only irrigation to turn it into a paradise. Nor is the water far off, for the mountains, which are in plain sight from the train, furnish abunclant supply, and every opportunity for huge reservoirs.

After a stop of trenty minutes at a small station to watch a man who was chopping wood-at least that was the only apparent reasonwe reached our journey's end, arriving at the city of Tehauntepec two hours late. ITe had elected to stop at the El Globo Hotel while in the city. and in that made no mistake, for it is the best there. From the proprietor's own advertisement I have it that there are "Kooms facineton 
two different street. Comorlios and well ventiloted." Moreover, with the true, up-to-rlate lotel spirit, he has the following card in each ronm:

"The proprietors of this hotel are only responsalile of lost of valuable objects or money when delivered to themselves hy passengers."

He handled the English language well, and knew it, and harl a profound pity for a plysician nearly who put out the sign "Engliselie Espoken." This hotel man was well worth the jommey to Mexico to meet. He is by hirth a Frenclman, who came over with Maximilian.

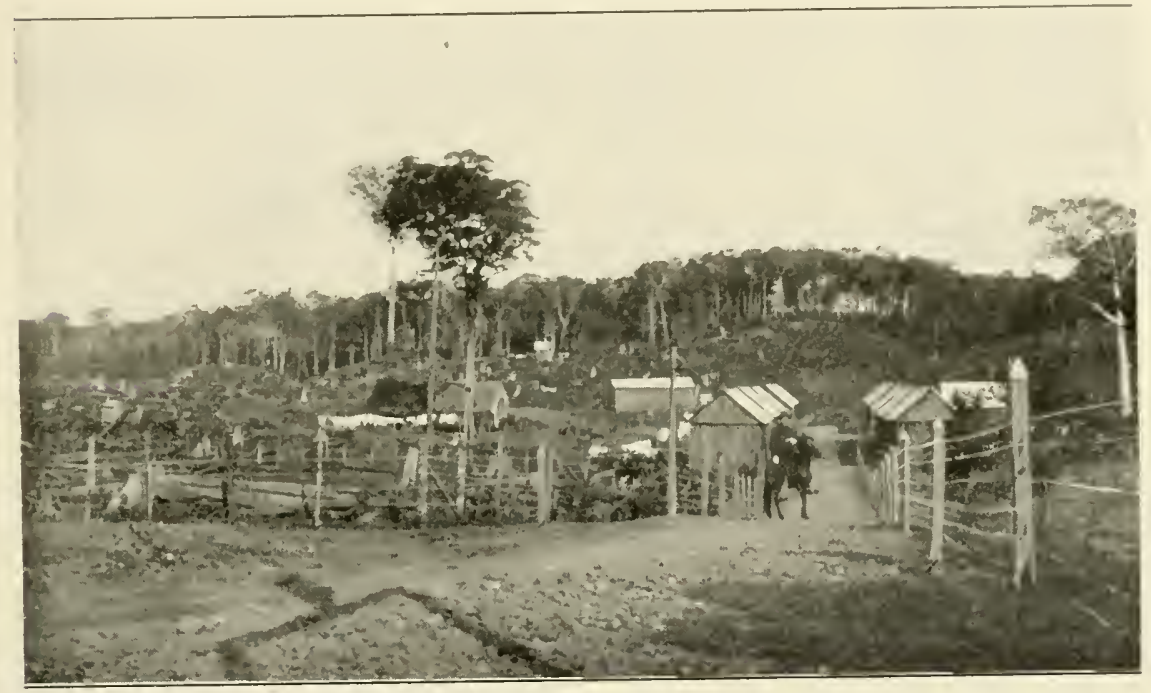

IHEL CORTE. - LABORERS CAMP AND CLE.IRING.

and after that unfortunate ruler lost his head, elected never to return. He is very short, alert, and the picture of vigorous old age. Occasionally. he gets a bit overstimulated, and then puts on an immense pair of cavalry boots, and strides about the place, giving orders in a thunderous voice, and entertaining his guests with reminiscences of European wars, that are full of thrill, dash, imagination, and doubtless some facts.

The hotel was a large, rambling, one-story affair, with tiled floors and small, cell like rooms opening out on an inner court that contained both dining room and kitchen. The bed roons contained two folding canvas cots, each of which had one sheet. one red blanket. and one little striped pillow that was as hard as if stuffed with shot. There were also two chairs. a table, and a wash bowl and pitcher of agate ware. The one 
window opened to the floor, and to keep thieves out and guests in, was latticed with half-inch iron bars. It was luxury, however, when compared with the native huts, and we rested well, and had no adventures. To be sure, I did have a queer experience the first night when I lay down for awhile with one hand hanging down by the side of the bed, and on drawing it up something dropped off with a soft thud that had me widle awake in an instant. A light and a search revealed nothing, and I came to the conclusion that it was one of the small vanpire bats that are common in Mexico, and that alight so gently on man or animal that even if wide awake they do not know it. So common are they, and so troublesome, that horses and mules are invariably kept under cover after dark, as these little blood-seekers rarely venture into houses.

The next morning it was quite cool, as a norther was blowing, and the thermometer registered only ninety-five. On arising. we took onr clothes in our arms, and clad only in pajanas, walked down the sandy street two blocks to the laths, where we luxuriated for an hour or more. After coffee, we visited the narket, and saw the far famed Tehuantepec women in their very striking headdress, of which so much is said: but asicle from its becoming effect, no one seems to know much abont it. I personally was interesterl to see how it was made, and so walked behind some of the dusky beanties as they marched off, and took a good, long look. The headdress is simply a white dress with a wide flomce around the bottom. This flounce is starched stiff and put upon the head so that it stands up like a huge ruffle. The rest of the garment, sleeves and all, hang down the back. I almost wish, however, that I dicl not know this, as the effect is not half as artistic since my eyes were opened.

There was really little of sightseeing in Tehuantepec; the market, the pucblo across the river, the ruins left by the earthquake four years before, were abont all. P'erhaps it was the climate. but it was more fun to sit on the brick sidewalk in front of the hotel and watch passersby, dog fights, and predatory pigs than to chase around after information. Anyhow, there was no rubber grown there, and rubber was my errand to the Isthmus. Speaking of logs, every Mexican and Indian in the hot country is a dog owner on a generous scale. Nor does he care what the breed, or the size, so long as the dog has four legs and a lark. They are, as a rule, a mangy lot, exceedingly lean, and many of them are really half coyote. All are plentifully supplied with fleas, which they generonsly divide with all with whom they come in contact. 

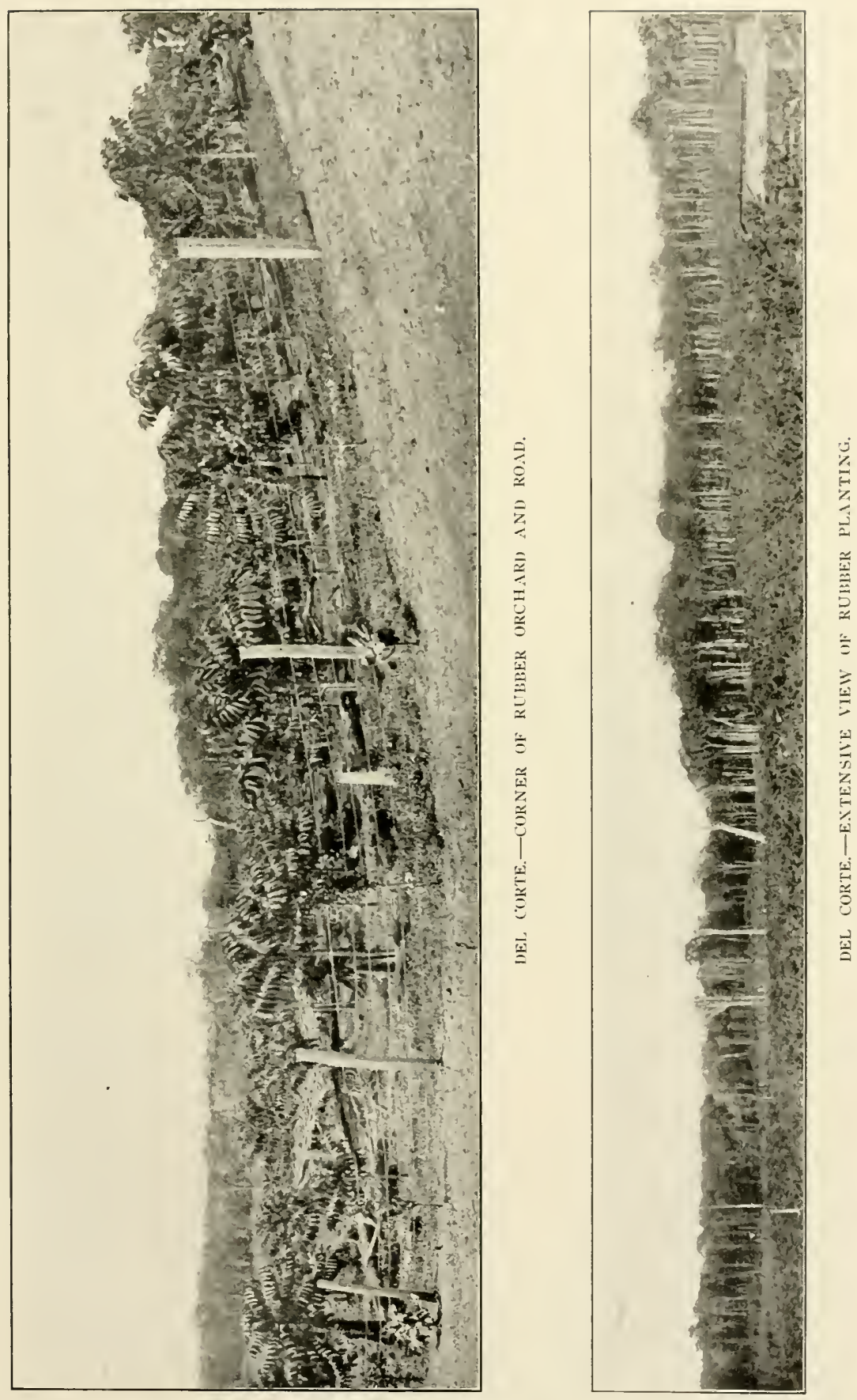
We left Tehuantepec on the morning when the first case of smallpox was reported, not for that reason, but because our visit was ended. It is a curious coincidence, but our departure from Coatzacoalcos was marked by the reporting of their first fatal case of yellow fever.

In spite of the fact that the clock at the El Globo had stopped, that the town clock in the plaza was slow, and that no one knew within half an hour just what time the morning train left, we succeeded in catching it, and arrived in Santa Lucretia in time for the midday meal. Major Elliott, whom we met on the way down, gave us a hearty greeting, but could give no information regarding the construction train to take us back to Santa Rosa. There were, he said, rumors of an accident, and no train had been through for two days. Some said it would be a week before they would be rumning again. As it had set in to rain hard, we possessed our souls in patience, and prepared to spend the rest of the day and the night with the Major. He readily made room for us, although the house was full, and then proceeded to give us an irlea of Mexican justice. It seems that an Italian workman, on a prolonged drunk, had for some days been terrorizing Santa Lucretia. After he had chased natives to his heart's content, he fell into the habit of bombarding the Major's hotel with stones, and casting lurid reflections upon the character of all its immates, from the proprietor down. These attacks were passerl over with silent contempt, until one of the stones hit the Major's son. who lost his patience, and with promptness and despateh thrashed the aggressor. Unfortunately in the doing of this he made the man's nose bleed, whereupon he was promptly hustled off to jail in a neighboring town, and it was only after three days of cliplomatic and financial effort that he was released. The Italian was not arrested.

The Mexican laws, as will be seen from the foregoing, are radically different from those that are so often broken in "The land of the free and the home of the brave," hut they are well fitted to the natives of that country, and act as a restraint to visitors, particularly those who feel superior to the dark skinned owners of the country. For example. if a foreigner gets in trouble with a native, even if the latter attaci him first, he is apt to be treated very much as if he were the aggressor. I know of one case, and heard of several others, where Americans were attacked by drunken or angry mosos armed with machetes, and who to save their lives, shot their assailants and were quickly arrested, and in spite of the fact that they proved that they acted only in self defense, remained in dirance from six montlis to a year there hefore being 
released. This, of conrse, is not right, and yet, for the vigorons-man! times lawless-irresponsibles that crowd into a conntry that is just awakening, as Mexico is, some such law is an absolute necessity, or the anemic population would be crowed to the wall, or wiped out. There are nany provoling things about the Nexican laws; for exannle, if a humber tean should run over and litl a native, the authorities in their anxicty for witnesses, and to place the responsibility, are apt to arrest not only the drivers of the team, but all the rest of the gang, and for a time look with suspicion on everybody connected with the lumber business.

The afternoon wore slowly away, and it rained harder every minute. It last cane supper and then bed. Here, as elsewhere, folding canvas

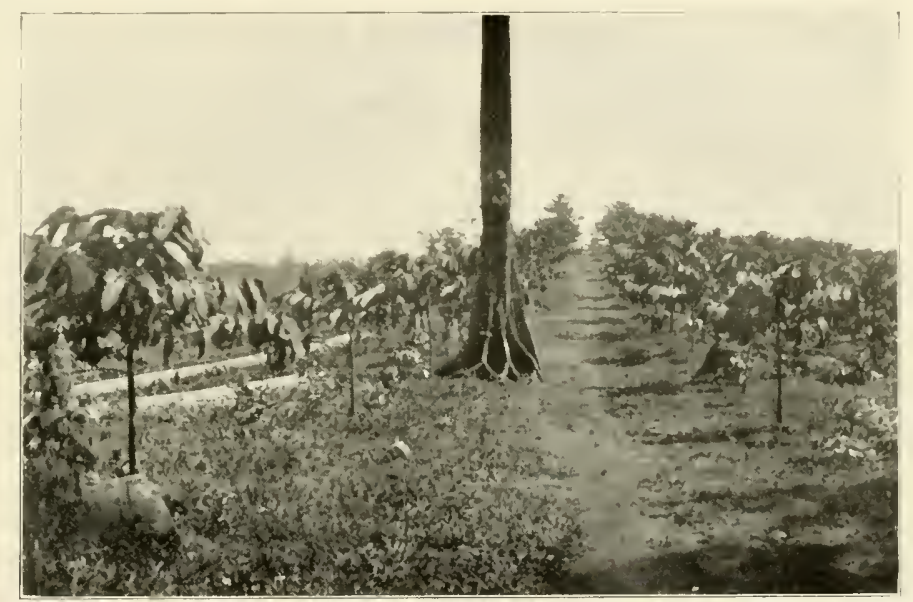

DEL (CORTE.-ROAD THROEGH REBEER.

cots were the only beds used. and while they are superior to an earthern floor, they do give one a crick in the back. Still we were thankful for our many mercies, and settled down to sleep. One by one the dim oil lamps were extinguished, and all was quiet except the monologue indulge 1 in by one guest who was somewhat inebriated. The Major reasoned with him, legging him to go to sleep, which at last he dicl: but the relief was only temporary, as he soon began again, talking in his sleep. Just as, used to this, we were dozing, a sudden crash shook the housea guest had fallen out of bed. The Major told him what he thought of such carelessness, and what he would to if it happened again, and once more quiet reigned. For a short time only. all was still, and then 
clump, clump, clump, along the passage between the cots came a heary tread. Feeping out from between the mosquito bars. I saw a man clad only in heary boots, tramping up and down the room. The Major discovered him at the same time, and wrathfully incutired what he was about. "Just taking exercise," was the reply. Then really the Najor let himself ont. It was truly a rhetorical masterpiece that he delivered himself of, and the offender at last reluctantly agreed to put off his constitutional until the morrow, and went back to bed.

It was still raining when we awoke, and we sat around all the forenoon waiting for the train, or for better weather. It was then that, looking at the passing mosos, I had a chance to see the native raincoats of cane and cocoa fiber that are the only mackintoshes the Indians use. They look far better and cleaner in a photograph than otherwise. and rubler manufacturers in the States need not fear that rubler markets will ever seriously seek them.

At two oclock that afternoon, as it was raining only a little, we loaded our belongings on a mozo, and started to walk the track to the railroad camp. twelve kilometers away. We got there finally, boots covered with mud, damp, perspiring, and weary, and were welcomed to the engineer's quarters that consisted of five box cars fitted $u$ p as dwellings, full of material comforts, and inhabited by several young and friendly Americans.

The head of this engineering household was Mr. F. M. Ames, chief engineer of the Vera Cruz and Pacific Railway, who has for seventeen years been at work railroad building, all the time in the tropics. Indeed, he headed the corps that surveyed the National Tehuantepec road, cutting his way through the densest sort of jungle, and establishing camps where now are thriving settlements. Mr. Ames knew the country, the people, and the animals, and we were soon launched into talk about the wild dwellers of the forest. Of the cat tribe, there are quite a number of large and active specimens. The leader of all these is the ounce, or as the natives call it, the tigre, and next to him come a great variety of spotted cats, diminutive specimens of the jagtuar tribe. They never attack man, and when hunted in rariably take to a tree. althongh before (loing so they often stop and finish a log or two, which they are fully capable of doing. They are more or less of a nuisance abont plantations as they have a great fondness for turkeys and chickens.

Many of the smaller mammals of the temperate zone are also very rommon, such as foxes, rabbits, skunks, squirrels, black and brown, and 
monkeys. This latter animal, I regret to say, wa comspicuonsly missing at the time of ny visit, the story bejes that a year or two hefore they harl taken yelow fever, and nearly all of them dierl.

It was during this most interesting chat that supper was announcel, and we were soon luxuriating on lan and eggs, hot biscuits. and fince coffee that the Chinese cook knew how to prepare to perfection. I conlel not help remarking that the Chinaman was alrearly consiclerably in evidence as a cook in the cities, at railway camps. and on plantations. Indeed, there are many who believe that the labor problene for the planter will be solved by the importation of a sufficient mumber of them. It is the general judgunent. however, that while they may be tanglit to clean the rubler from weeds and vines. and to do a certain annount of culti-

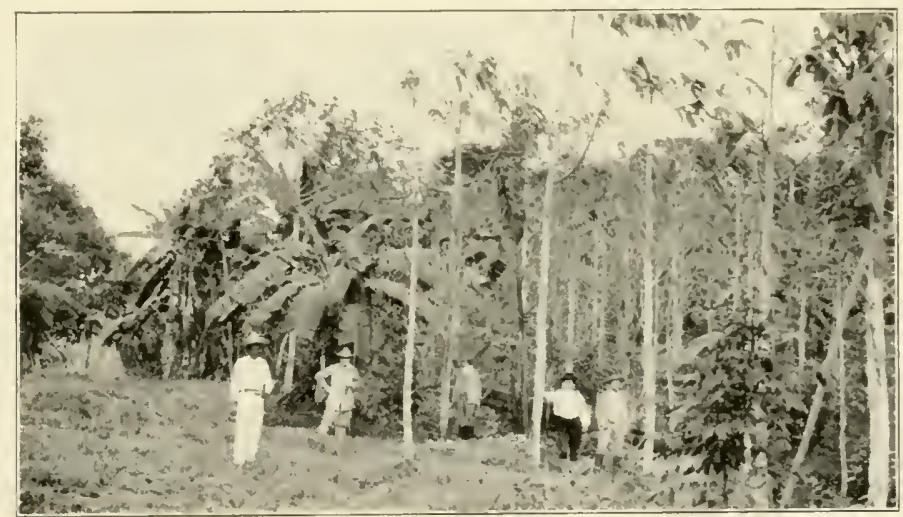

TREES ON FILISOLA.

[Photo Copyright by C. B. IVaite.]

vating, that they will not be of much use either in forest clearing. or in tapping. In addition to this, the prices that the Chinese companies want for securing coolies is at the present time much too high to allow of their profitable nse.

Mr. Ames, his two assistants, Messrs. Jones and Hawkins, my companion and I spent a very pleasant evening in what perlaps might be called the parlor car, and later adjourning to the sleeping car, forgot everything earthly mutil awakened in the early norning by the shrill whistling of a lncomotive. This was the signal for breakfast and an early start. In due time we boarded a flat car in front of the engine, and were off for Santa Rosa. We sat in a row on the extreme front of the car, rearly to jump if it left the track. Along the route the worthy chief showed us 
Where such slight mishaps had occurred, explaining that, until the coming of the dry season, and it was possible to put in ballast, such a condition of affairs had no remedy.

WTe reached Santa Rosa in lue time, and as a sonvenir of my visit. Mr. Anes gave me a colrilla nut, a mative remedy for all kinds of snake bites, as well as for coast fevers. I have since learned that the malnogany cutters, and other foresters of the tropies, put great faith in it, and rarely venture into the forest without it.

Leaving the railroad we struck into the new trail already mentioned, hid our luggage until a moso could be sent for it, and started to walk to La Buena lientura. The rain had ceased, the sun was shining brightly, and every bird in the forest was singing a song of rejoicing. Not always in tune, however, for the genuine feathered warbler of the hot country is not at all musical. The chachilatta thinks it sings, but as a matter of fact it simply "chachilatters," and that word just describes the somnd. A sort of wild hen is this bird, and one that is in eonstant hysterics.

After a walk of about fifteen minutes, we encrged from the forest and ascended to the higher ground where grows the rubber. To onr regret we arrived too late to join in a tapir hunt that took place in that very orchard. The tapir is the largest wild animal in the Isthmus, and although quite plentiful, is so shy that it is rarely seen. It is perfectly harmless, and its flesh is esteemed a delicacy by the natives. One of them by some chance wandered into the rubber, and the son of my host fired a charge of shot, knocking him over. He recovered in an instant. and rushed away, taking another charge with him.

We did not tarry to talk tapir, however, but hastened on, botli of us anxious to get our mail. Is I had received no letters since leaving the City of Mexico, that longing had a reasonable basis, but when I appreciated the difficulty in getting letters through, I did not wonder at the delay, but marvelled that any mail at all reached me. So we hastenerl on over the rubber covered hills and finally reached the ridge on which stands the house, and on which, too, is grouped the marvellous collection of tropical plants and trees referred to in a previous letter. Many of these, by the way, were olntained through the courtesy of the officials in far clistant Pritish botanical stations, notably, Calcutta, Singapore, and stations on the west coast of Africa. Indeed, Mexico owes to these officials and to Mr. Harvey's enterprise the introduction of the Kick.ria Africanus and the Heica Brasilicnsis.

We reached the plantation house at last, and everyone welcomed 


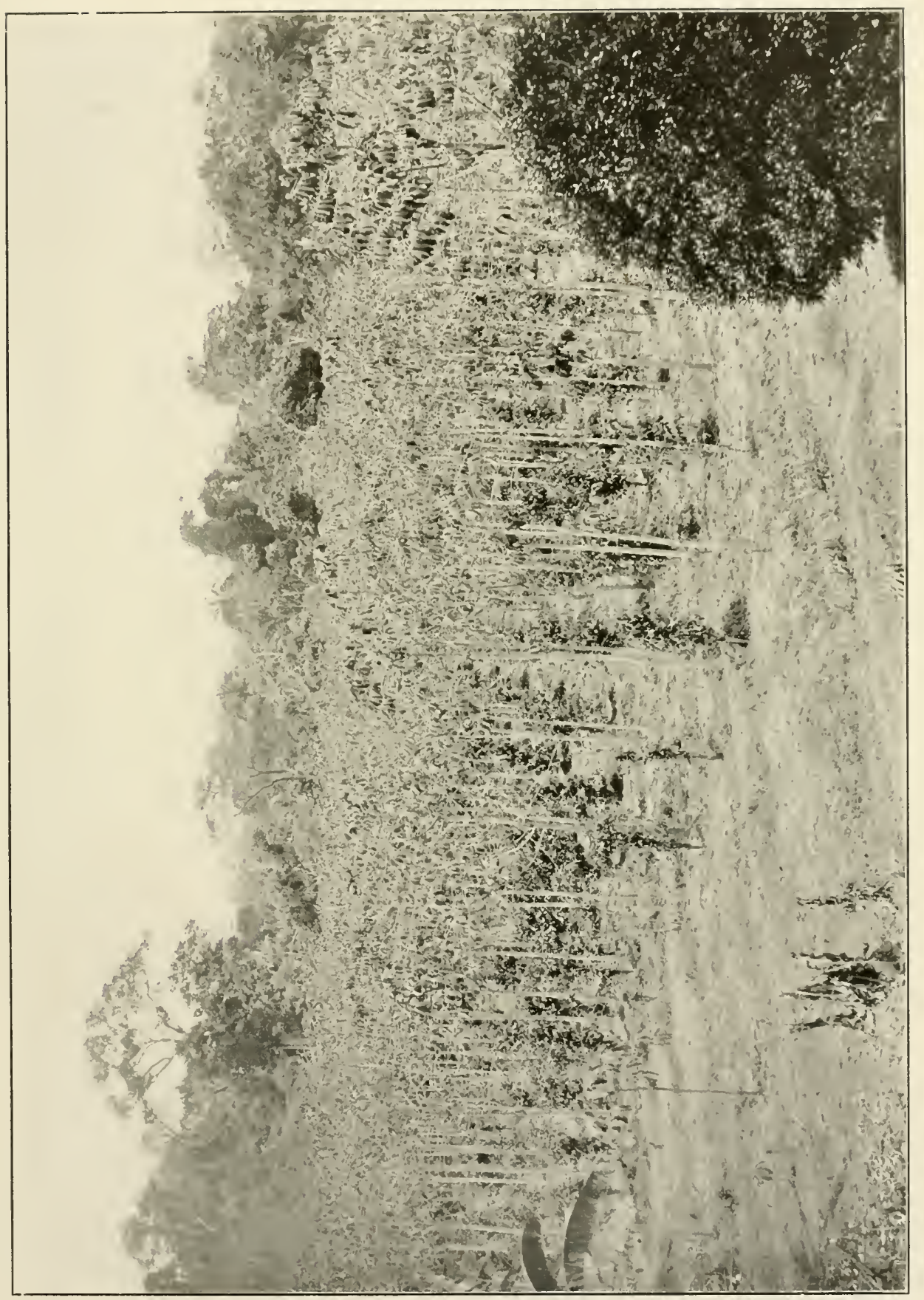


us warmly. The tame macaw, the little green parroquette, Lora the parrot, and even Bola, the big yellow tomcat, vied with the dogs in an enthusiastic ovation. Things seemed to be about as we had left them, and except for the fact that my black shoes had gathered a fur of green mold. and one of them was occupied by an enormons spider, I was perfectly content. Speaking of spiders, there are many of them, but they are the least of the insect troubles. If left alone, they are harmless and not much in evidence, but the rodador. the pinoleo, the chaquista!they are looking for trouble. The rodador is like the black fly of the North Anerican woods. It is in some places most abundant, and its bite raises an itching lump that lasts several days. After a little. however, one becomes inoculated with rodador virus, and the only result is a small black spot that scales off without any itching or burning. They trouble some neweomers exceedingly. but I found them only a slight discomfort. not important enough to take any special precaution to mitigate.

Anong the insects that are most easily domesticated, and that attach thenselves with instant affection to the passing traveler, I should nane the pinoleo. the conchudo, and the garrapata. They are all related. and are of the tick fanily. The finoleo has a habit of associating with himself several millions of others, each one the size of a pin point, and hanging on a leaf or twig over a trail where animals or men are accustomed to pass. When the branch is touched, they instantly catch on to whatever touches it, and proceed to distribute themselves over the body and seek for tender spots wherempon to feast. I had a most abundant and energetic collection of pinoleos on several occasions, but got rid of them without much trouble.

The conchudo is simply a pinoleo that has not been blotted out early in life, and who grows into a fairly sizeable tick. He does not burrow into the flesh, but simply hangs on, and grows fat off the animal of his adoption. The garrapata is the pinolco grown to maturity. and is a goon large ablebodied tick that fastens himself upon his victim, and is very reluctant to let go. Another little pest that troubles some people is the chaquiste, a fly so minute that one can hardly see him, and that hides itself in the hair of the head, its bite being like the sting of an electric needle.

There are, of course, mosquitoes, although personally I was troubled very little by them during the whole of my trip, and ordinary Heas are to be found in the towns and cities from one end of the comntry to the other. The insect that I most dreaded, however, and which was described to me by many of the old time residents, was the moyayuil. This is a grub 
which burrows in the flesh. and which when approaching maturity is about an inch long. It is stupposed to be hatched from the egge of a fly, some say a butterfly, and is very easily disposed of if one knows what it is. When once imbedded in the Hesh, it has the appearance of a blind boil. but under a magnifying glass, the head of the creature can be seen just above the skin, and a little sticky substance, such as rubber sap, suffocates it, and it is easily extracted.

The next two days were set ajart for more plantation visiting. but my good luck, as far as weather was concerned, suddenly fled. It raineil so harel that traveling would have been torture, and visiting folly, so on the third day I turned my face towards the City of Mexico-a far cry, bowever, for first must conc a long aftemonn's tramp along the railroacl track to Achotal. We did it, reaching the town at dusk. Then followed

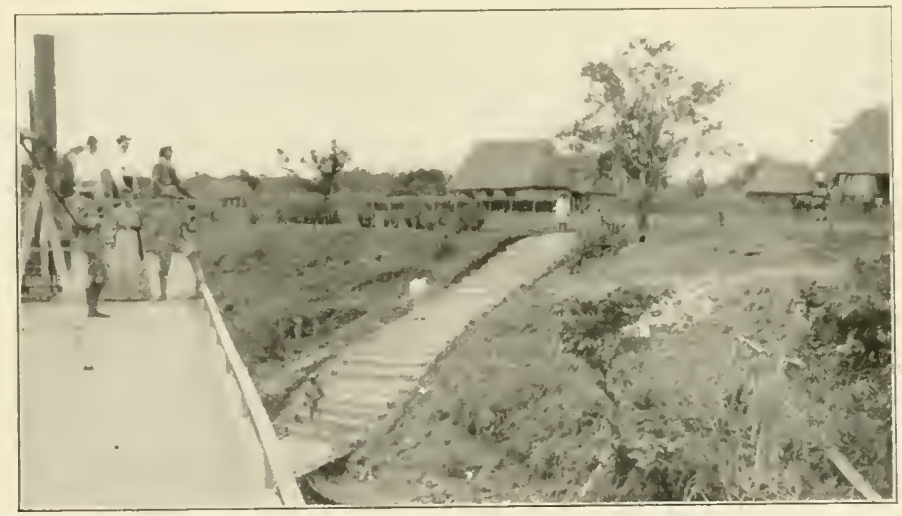

FILISOLA IX ITS PALAI DAYS.

[Photo Copyright by C. B. Waite.]

the wait until one in the morning. when the train arrivel. We waited on cots in Antonio's palatial shed, which we shared with mozos, dogs. pigs. mules, horses, and the "murderer." The last named was the only really. interesting bit of scenery there. He appeared soon after the rest were asleep, and crouched by the side of the door of the next hut. his sullen face filled with hate, his hand toying with the hilt of a wicked looking knife. He wasn't after us, so we let him alone. At I2.30 we got up. took our traps. stumbled over a family of sleeping porkers that were lying in the passage between the huts. sidled down a narrow plank to the railroad track, squeezed in between a lot of mozos who. wrapped in blankets, covered the depot platform, and awaiter the coming of the 
train. While we sat there, one of the mosos roused up, and began to talk to my companion. After a time, Mr. Harvey turned to me and said :

"Here is a most remarkable thing; this man was on his way to my. plantation to get work, when some of the railroad men told him that I drove my laborers out in the field early in the morning, hitting them with the flat of the machete, that I fed them very poorly, and made them sleep in a fenced enclosure that had no roof over it, so he didnt dare come. That is the way they try to get our help for themselves."

At length, after what seemed an interminable wait, the train arrived. and we got aboard. The train boy had some canned beans and crackers from which we made a hearty meal, and then, stretching out on the seats, we slept as best we could until we reached the breakfast station at Perez. The breakfast was fair, but the fruit we bought later was really what made life worth living. At every railway station, women and children gathered under the car windows with fruits, flowers, native made candies. and the great variety of sweet cakes of which both Mexicans and Indians are very fond. I got a dozen oranges for ten cents, and they were simply delicious. I fruit that I had been very anxious to taste was the sapadillo, produced by the tree from which the chicle comes, and, finding then on sale at last, I immediately invested. It is about the size of an apple. with a skin like the potato, the pulp tasting like gelatine filled with brown sugar. I also sampled many other fruits. Of them all, as might be expected, the banana is the most common, and I observed several varieties that are never seen in the States. Some tiny yellow ones, a little larger than one's thumb, have an extremely delicate flavor, and are delicious. Of this family is a large plantain which is either friect or broiled, never being eaten raw, and which is extremely palatable. There are a great variety of other fruits which appear at certain seasons, such. for example, as the sour sop, a sort of pear with a prickly alligator skin hide, and which tastes like sour snow mixed with cotton batting.

During the forenoon we rode through a country largely given up to cattle ranches. Of domestic animals in Mexico, the cattle are perhaps the most valuable, and even with the poor strain of stock that is bred. many large fortumes come to the owners of the ranches. Besides this. those who go into the cattle business have no trouble at all in getting help, as the native Mexican is a natural cowboy, and if he has but a pony and a big set of spurs, he is willing to work as he is at no other calling. Some of the nore progressive ranchers are crossing their cattle with imported stock, and setting fine results. Most of the rubber planters 
keep a certain nmmler of cattle for their own immerliate wants, and for feeding the help, and occasionally they are able to get a little fresh milk; but few of the cows are good milkers, and for native use, goat's milk is very extensively used.

One thing that I harl a chance to clo on this forenoon's journey was to look over the notes that I had taken relative to the manner in which real estate, and particularly plantations, are taxed. This is not an interesting subject to the casual reader, so if he will kindly skip a few paragraphs, and allow others the privilege of reading, it will be estecmed a favor. It seems that there is an actual tax for the transfer of property, which is called traslacion de domino, assessed in the following manner: Two per cent. is charged on the value stipulated in the deerl.

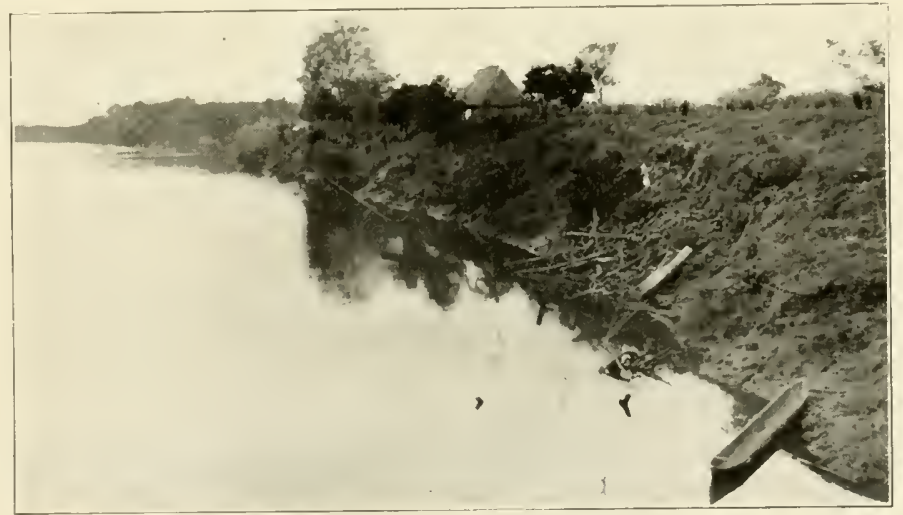

FILISOLA WATER FRONT AT PRESENT.

[Photo Copyrighted by C. B. Waite.]

provided that value is equal to or more than the official value, the latter being the value on record established at the last sale of the property, or if there has not been a recent sale, established by the valuation conmittee, called the junta calificadora. This two per cent. is the state tax. and on this two per cent. is charged thirty per cent. federal tax. If this transfer tax is not paid immediately after the execution of a title. a fine of twenty-four per cent. per annum on the amount of sale. or the ifficial value if the property is charged. Govermment registration of a title is not allowed mless this transfer tax has been paicl. This transfer tax applies only on real estate, and is charged only when property changes hands.

Country real estate (fincu rustica) is calculated as follows: Six per 
cent. of the value is figured: upon this amount five per cent. is charged as a state tax for the year, and upon this same amount thirty per cent. is charged as a federal tax. These taxes are payable the first of each quarter or yearly in advance. Failure to pay during the first month of each quarter subjects one to a fine of six and one-quarter per cent. for the first month, twelve and one-half per cent. for the second month, and for the third month, or thereafterwards, twenty-five per cent. The only products in the locality that I visited where taxes are charged are coffee, sugar, and tobacco, and upon these four cents per are is leviec. This are is one-hundredth part of a hectare, and a hectare is $2.47 \mathrm{I}$ acres. On this four per cent., thirty per cent. is charged as a federal tax. These taxes may also be paicl quarterly or yearly, and if not paid during the first fifteen days of each month, a fine of six per cent. is charged and if not paid during the first two months of each quarter or later, twentyfive per cent. is charged. It will be seen that these taxes are very light, and the government gives the planters the privilege of making their nwm manifests as to the area of the land under cultivation, and invariabl! accepts these in good faith.

That night we spent in Cordoba, and the next morning went early to Orizaba to recuperate. We both were in need of rest, and felt the effect of that fine dry climate almost at once. Orizaba, be it said, is a most civilized city, quite a resort for health seekers, and its guardians look with great disfavor upon the free and easy inhabitants of the country south. I was somewhat indignant at the looks cast upon me by the policeman, until I learned that it was against the law to wear a revolver. so I gladly unshipped mine, and stowed it away in my bag. Not that the city is really prudish. It runs a big public gambling house, which every dweller patronizes, and the profits from which go for municipal improvements.

I met many Americans there, among them Maxwell Riddle, who was shivering with calentura, and was hastening back to Tierra Blanca to sweat it out; John W. Byam, on his way to the San Marcos plantation, accompanied by Mr. Wood, his manager, who was just back from the Congo Free State: Mrr. Cavanaugh of Perez, and many others.

We luxuriated in Orizaba, attencled the theatre, saw the poorest centimatograph show on earth, learned from the natives that the American national hymn is "There's a Hot Time in the Old Town Tonight," and thuss improved both mind and body.

Finally I was rested, and Mr. Harvey had secured a lot of rare orehids from a learned old Mexican horticulturist there, and further 


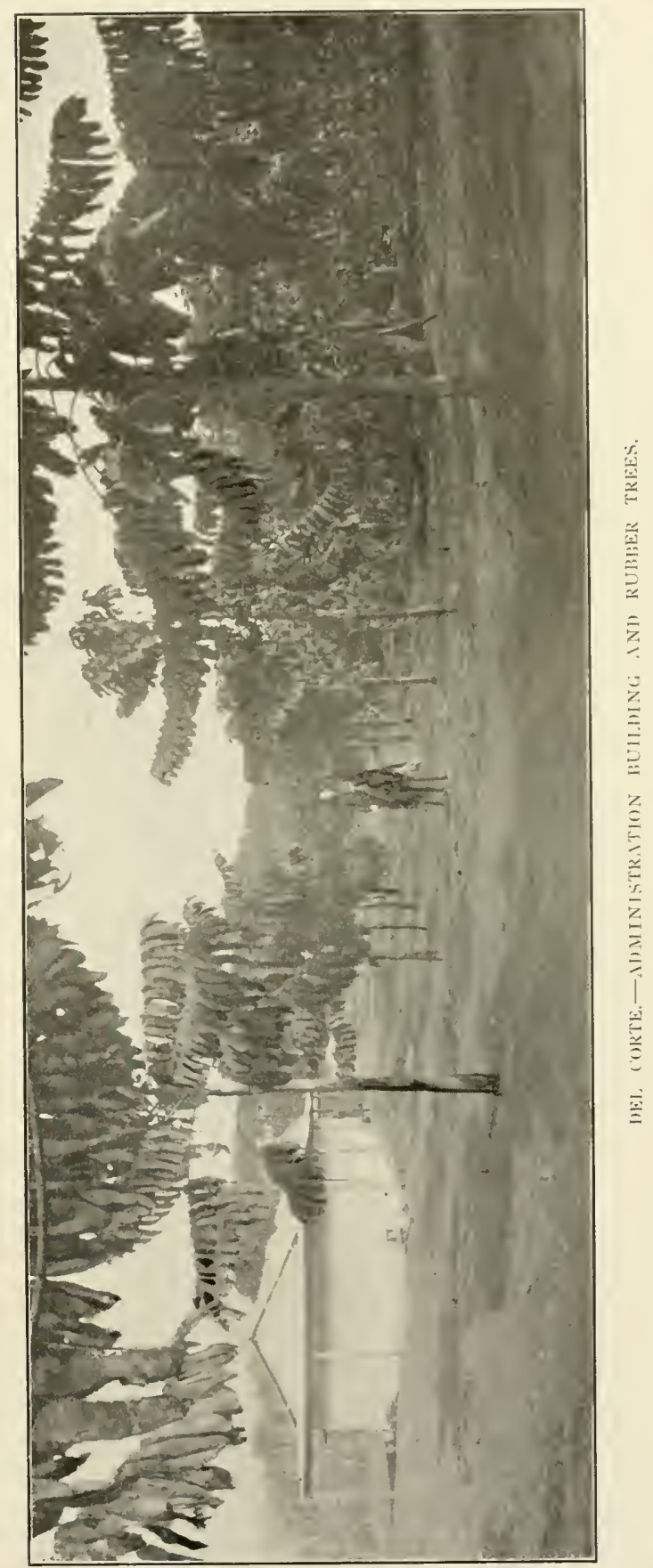


arranged for an exploring trip with him later, and the time had come to part. I tried hard to get him to visit New York with me, but with the true tropical dread of pnemmonia and grippe, he sturdily refused. With a simple handshake we parted, but I wish he could have looked into my heart, and read there the gratitude that I felt, and how I appreciated the hospitality and consideration that he had shown to the tenderfoot who dropped in so suddenly upon hin, rode his best horse, stole the affections of his parrot, and wore a hole in his favorite canvas chair.

On my return to the City of Mexico almost the first people that I met were Messrs. Warren and Willian Fish, Mr. Charles E. Sieler, Mr. S. D. Dorman, and Dr. W. S. Cockrell, all of whon have interests down in the Trinidad River district. I had met these gentlemen before, with the exception of the last named, and as he has been interested in rubber cultivation for nine years, I was glad to get an expression of opinion from him. He is a very earnest advocate of close planting. I believe he laicl it down as a rule that the distances between the trees should be six feet and six inches. He has also gone into the subject of smothering the grass by the use of the cow pea, and strongly recommends the whippoorwill variety. He said that his own observations proved that when the Castilloa was planted in a soil that consisted of a thin layer of loam over gravel, the trees did very well for three or four years, and after that seemed not only to stop growing, but that they produced very little late.r.

His remarks remind me that in transferring my notes I left out my visit to Filisola, a plantation that is not only an acknowledged failure. but one that is practically abandoned. As the record of failure is often of more value than is the story of any number of successes, I am going to ackl it right here.

It was hot-awfully hot-as we climbed up the hillsicle to the rubher trees. On the way we walked in single file. constantly thrashing onr leggings with switches to dislodge the clinging pinoleos. ( ) n the rolling ground above the landing. we found a stand of trees, said to be seven thousand in number, planted about twelve feet apart. Most of them were in the sum, but quite a lot were in among banana trees, and harl good shade. Those in the sun were knee deep in grass, which was not of one year's growth. but slowed a permanent sod. Those in the sharle were free from grass. All of the trees, however. looked aged, not in size, but from the wrinkled condition of the bark, and the gray lichen that covered it. Iet those trees were hut seven years old. They yielded some late.r. but the most optimistic seller of rubber planting stock would 
not dare predict that they would ever grow another foot. They lowker matured, funished, discouraged, and a physical examination of the soil explained it. A thin leaf mold, then sandy clay with a trace of iron, then clay, and the whole as dry as a smoked herring. was what it showerl. I variety of opinions were put forward as to the cause of the failure of this venture-mismanagement, poor soil, had seed, grass, etc.-but to my mind the soil told the whole story.

I have had so many inquiries concenning the cow pea that I want to add a word concerning it. The botanical name of the ordinary variety

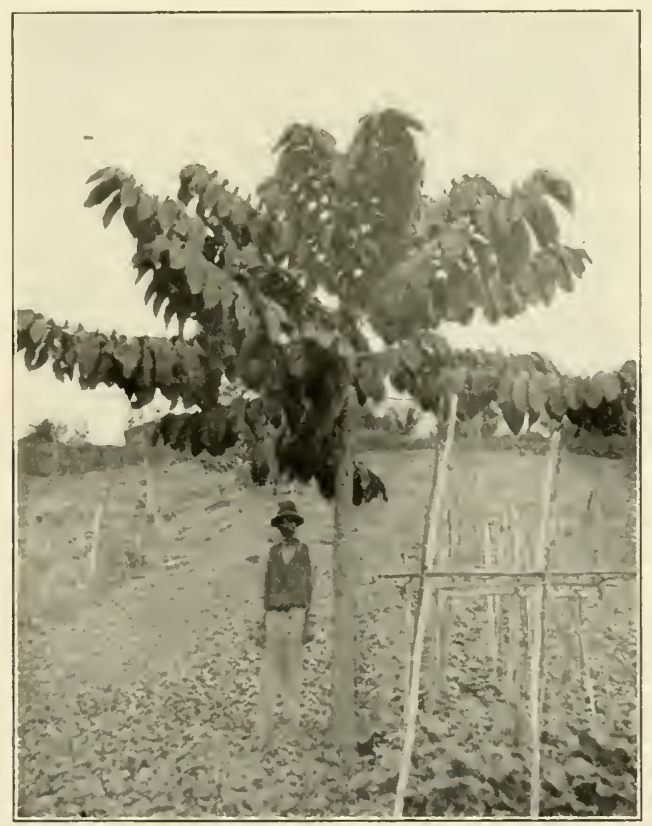

RUBBER TREE 2T MONTHS OLD FROM SEED.

is the Figna kantuing. It is one of the well known lexuminous plants of the southern states. grown partly for fodder and partly for hay. It makes the land richer because it returns to it so much of the mineral matter taken from the soil, and in addition much nitrogen from the air. There are a number of varicties used through the southern states. such as the "clay." the "unknown," and the "whipponrwill." The advantages of the cow pea are, it is a nitrogen gatherer; it shades the soil in smmer. leaving it friable and loose: it has a large root development: is adlapted to almost any sort of soil: stands heat and sunshine well; and if sown 
thickly, will, by its rapid growth and shade, effectually smother all weeds, thus serving as a cleansing crop.

There is another plant which rubber planters might well look into, and that is the velvet bean-the Mucuna prusicus (var. utilis). This plant comes originally, I think, from Tampa, Florida, and no doubt the Florida experiment station could tell all abont it. It is said to have even a more luxurious growth than the cow pea, and produces a great amount of vine, and a large yield of seeds. It covers the ground with so heavy a vine that it is reported to have killed temporarily even the cocoa and Johnson grasses.

When one is in a foreign country, and almost ready to start for home, and a bit homesick at that, there comes a moment when all deterrents are brushed aside, and one bolts. I had planned several dars sightseeing, and a stop off on the way, but instead I bolted. I met all sorts of nice chaps on the return journey, yet it was a long week that elapsed ere I sighted the skyscrapers of New York. Now that I am here. I wish somewhat that I had stayed a trifle longer, and I find myself yearning again for the open air life, the strange experiences, and the glimpses of nature-luxuriant, triumplant.

Will this wishful attitude draw me back there soon-I wonder! 
A VISIT TO RUBBER PLANTATIONS IN NICARAGUA 



\section{A VISIT TO RLBLER ILANTATIONS IN NICARAGUA.}

ON Bonki The Sunbeam-Decenliek Heat-Meeting a Water SpoutArriall at Bliefielis-Up the Esconiho-Alorning Glory Vines Anong the Rubber Trees-Derastation of Castillo. by Healy Rans-Ixteresting Experianents in Tapping-The Maniattan Plantation-Visits to Other Ruber Growers-Diselses of tue Castilloa-On a firuter to Nen Orleans.

X $Y^{E}$ three, the Importer, the Mannfacturer, and the Editor, leit Port Limon, Costa Rica, at 1.30 in the afternoon on a hot. tropical December day. The short voyage from Port Limon to Blucfields, something like one hundred and fifty miles, was to be taken on a small, fifty-two-ton schooner owned by Belanger's, Incorporated, of Nicaragua, and used in trading up and down the coast. The

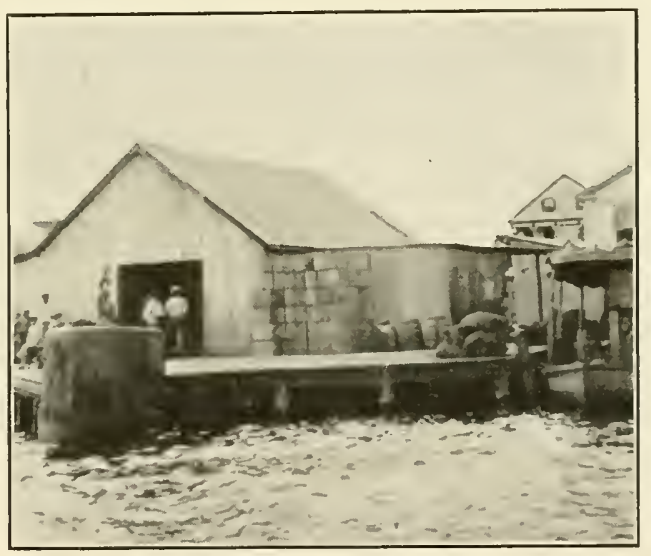

IIHARF AT BELANGER'S.

schooner was equipped with a gasoline auxiliary which took up most of the room aft, and made the rest of it so thick with gasoline fumes that it was difficult to stay in the cabin ten minntes at a time. so we lived on deck. The ressel was called the Sunbcam and was manned by a mixed crew of negroes from the Fortune Islands. San Plas Indians, and one Englishman, and was commanded by a Cayman Islander.

Starting out against a head wind, our gasoline "kicker" put us along at the rate of about four miles an hour. and we sat scorching on deck until finally the sun set and we turned in, still on deck, sleeping 
in our clothes, on a pile of old sails in the stern of the boat. The bed was far from comfortable for one at all finical about the soft side of a plank, and the Inporter did not take to it a bit. He had chosen a place next to the bulwarks, and had only one ring bolt in the small of his back, while the Manufacturer was curled in the form of an S around a huge cleat, and a part of the steering gear. However, morning came at last, and the little boat kicked along through a blazing sun at first, until it finally clouded up, and later, about three miles to the northeast, a huge waterspout was sighted. We were all so dull and drowsy that we didn't pay much attention to it at first, but when it drew nearer and nearer, and the captain furled all sail and made everything fast, we

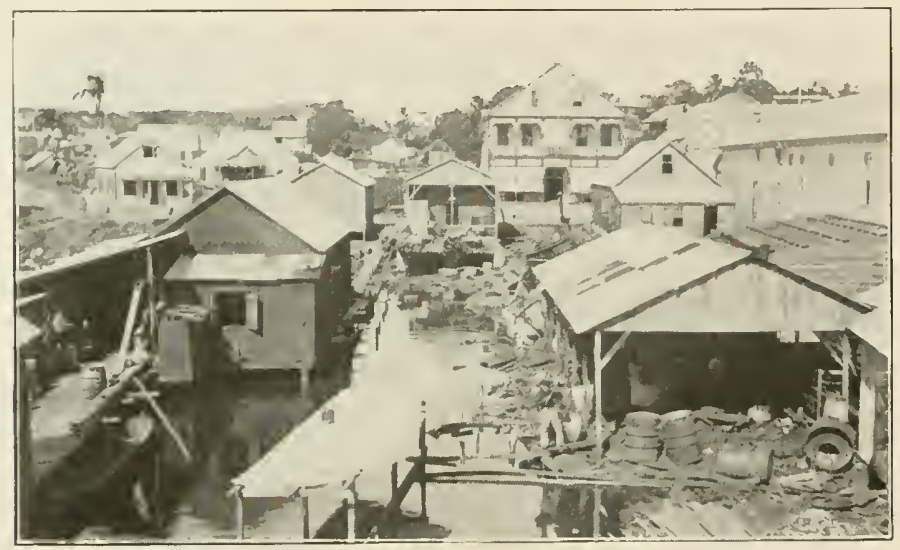

WATER FRONT IT BLUEFIELD'S.

thought it might be possible that we were going to have some fun. It was the first time I had ever seen anything but pictured waterspouts, and I had always been a bit skeptical about them; but as it got within a few hundred feet of 11 , I was a most thorough convert. It was really a most remarkable sight. The sea was quite smooth, except where the end of the great funnel touched the water. and there it was broken up into curious little wavelets. The huge circular tube of vapor did not go straight up, but slanted off into an especially lolack cloud and appeared to be a mile and a half in length. When it was near enough. the captain began shooting in its direction with an old-fashioned Colt's revolver, and the Manufacturer, getting his gun, tnok a hand in the same game. Whether the concussion dicl the work or not. I don't know, but hefore it reached us it suddenly dissolved, and in a very few seconds no trace of it was to be seen. 
After that we had no itrther excitement except the catching of a big king fish, which helped out our table immensely. That night we slept again on deck, and went through several slowers, sailing into lihnefields about nine the following norning. where the doctor passed us as "healthy, but ugly:" Then we went w) against the custom house officials at the bluff, whe fingered our belongings for anything contraband, seeming to take particular delight in ruming grimy fingers over our toothbrushes, and to have a deep anxiety to unroll camera films, and so on. We got rid of then at last, and boarding a flat-bottomed sternwheeler, were taken across the broad expanse of Bluefiekds Bay, and landed at Belanger's wharf, from which we went at once up to La Trop-

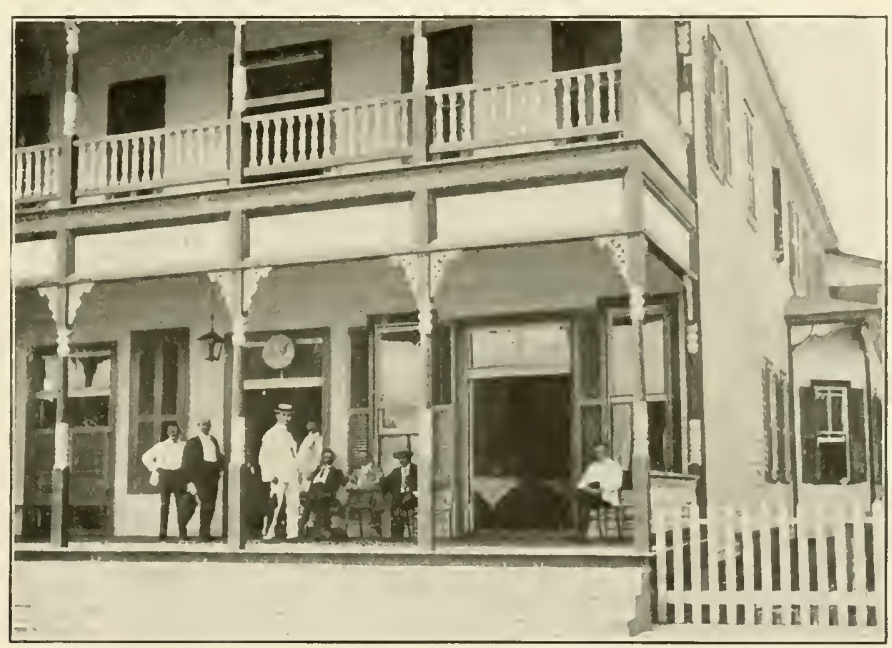

L.I TROPIC.IL HOTEL, BLUEFIELDS.

ical Hotel for a bath and breakfast. There was but one bathroom, and that was situated over the kitchen, which was proved by the sign on the wall: "Don't slop water on the floor: range just below. Gives food a soapy flavor."

After breakfast we went out and looked over the little city of frame houses, so radically different from most Central American towns. both in its architecture and in the fact that it is built on a side hill where there is a certain amount of drainage. We dicln't tarry long in Bluefields, however. for our flat-bottomed hoat, Nat, $J_{r}$. a sternwheel freighter was waiting, and with our luggage aboard we soon started 
up through the wonderful system of lagoons and waterways that were to be our pathway to the rubber plantations.

These comprise the Bluefields River, the Escondido ("Hicklen Waters") River, and a great variety of deep lagoons and waterways, intermingling in inextricable confusion, shut in by walls of tropical foliagean expanse of natural passages so great that a nay might easily be bidden there without the remotest chance of detection. Indeed. in the old days of the buccaneers, these lagoons were favorite retreats, and if closely pursued a vessel could slip into one of them, tie a few branches to her topmasts, and def $f_{y}$ discovery.

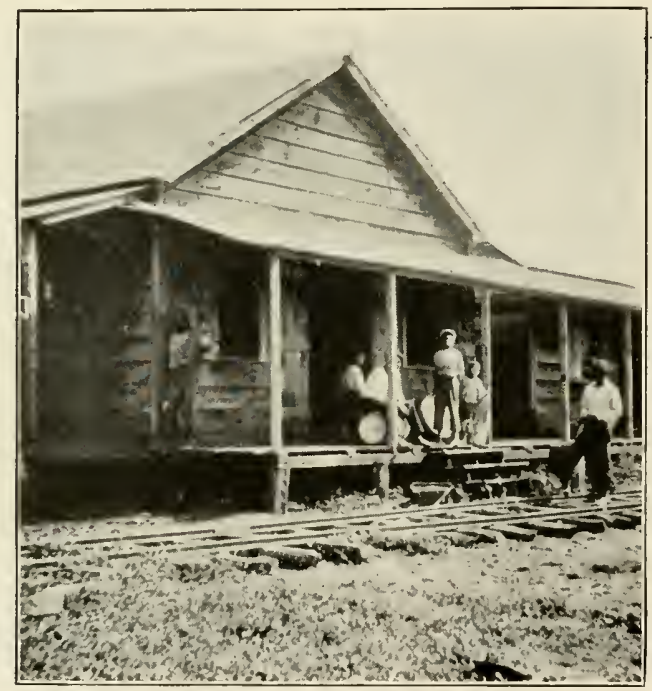

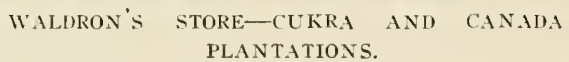

The ride up through the Escondiclo was simply entrancing. There was scarcely a ripple on the water: the foliage of palms, palmettos, mangroves, and wild bananas, interspersed with patches of pampas grass, the stalks of which were twenty and thirty feet high, bound together with vines and spangled with flowers; the huge flocks of blue and white cranes and the basking alligators-all made a panorama so wild in its tropical beatty that it added new fascinations every moment.

Finally, late in the aftemoon, we turned into Sloophouse creek, and a little later were moored at the pier belonging to the Cukra 
plantation. Here we disembarked, and leaving on lusgage to be brought up later, followed a narrow-gauge banana railway up over a little hill thromgh a part of the fiftecn-hundred-acre banana plantation of the Cukra Company, and were soon at the house of Mr. (iordon Maldron, one of the owners, where we had a bountiful sulper and a most interesting chat, chiefly on rubber. After supper, in the bright moonlight. we boarded a flat car drawn by a diminutive engine and rocle three miles into the country to the road that les to the Manluattan plantation. There saddle horses and a wagon were awaiting ns, and as it had suddenly clouded nu) and begum to rain, the lmporter and I got on the top of the baggage, preferring to trust ourselies to a wagon rather than a horseback ride through the pitchy darkness. The road was far from smooth, and we got anple exercise before reaching the plantation house.

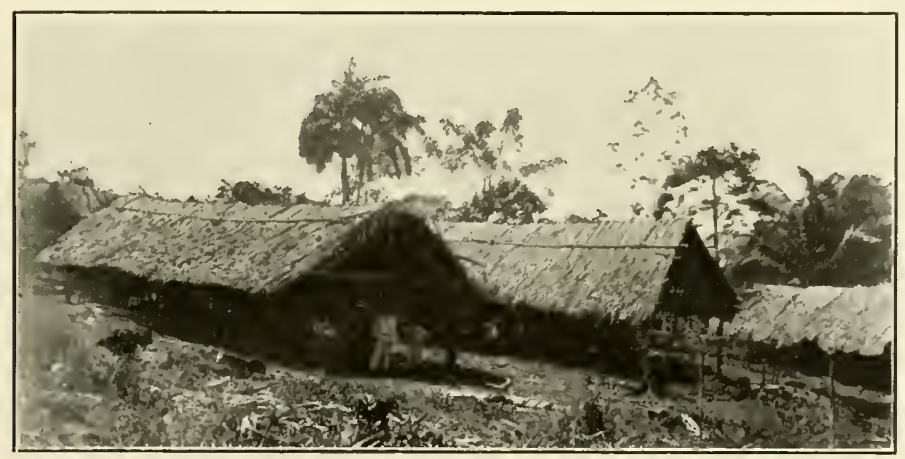

WALDRON'S CANADA PLANTATION.

We did reach it finally, at 11.30 , and turning in muder mosquito nets, slept like tops.

At daybreak the whole crowd roused out, and going to the door we found that we were riglit in the middle of planted rubber. It was on all sides of us, even in the yard. The average age of the trees was about three years and they all looked stocky and thrifty. The soil seened to be a red, loamy clay, quite porous, with considerable volcanic rock through it. and the country rolling rather than flat. The soil was excedingly deep. as was attested by several wells that had been sunk, the leepest being forty feet, which had not got through that formation.

That the trees bled very freely. I was able to prove before breakfast, as I walked around and ran my knife into the spongy bark. A little 
later, when we started out on our tour of inspection, the Importer, who would not ricle horseback, was fitted out with a sort of buckboard, drawn by a mule and driven by a Southern darkey known as Jake. The rest of us rode horses.

Amost the first thing that struck me about the planting problem down there was the remarkable prevalence of the morning glory vine. Just as soon as the land is cleared and planted it takes possession, and if it were not cut down constantly around the young rubber trees, it would most effectually smother them. When the trees get a good start, the vine suddenly dies out and the grass comes in. My belief had always been that for grass to get into rubber was fatal to the growth and pro-

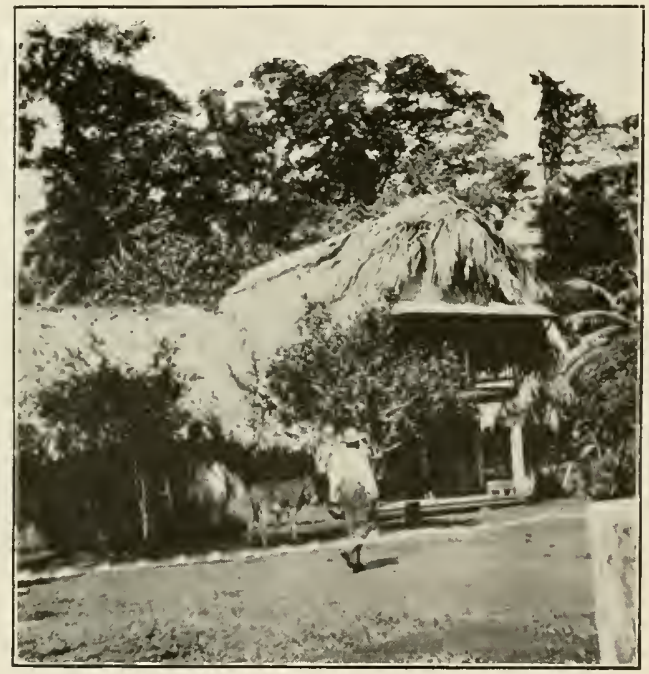

RESIJENCE OF SIM IRON.

ductiveness of the tree. I saw acres down there, however, with the grass growing among the three-year-old trees, and they were apparently as healthy and thrifty as they could possibly be. A little later the shade of the tree seems to discourage the growth of the grass, and in one planting, where the trees were between four and five years old, the grass had practically disappeared.

The refusal of the Castilloa to put up with too much water was emplasized by the fact that a section of land, containing perluaps ten acres, on the Manlattan plantation, where during the heavy rains the water had not drained away quickly enowgh, most of the trees had died. 
Speaking of the rain in this section, the local report is that there are about two hundred and fifty inches a year. I don"t know that that is the result of actual measurement, lut while we were there it certainly rained about as easily as it does in any part of the world. During a forenoun's ricle we would often go through three or four showers, not heary ones, but the gentlest sort of refreshing spring rain. The elevation of the bunch of plantations that we were visiting is about two hundres and

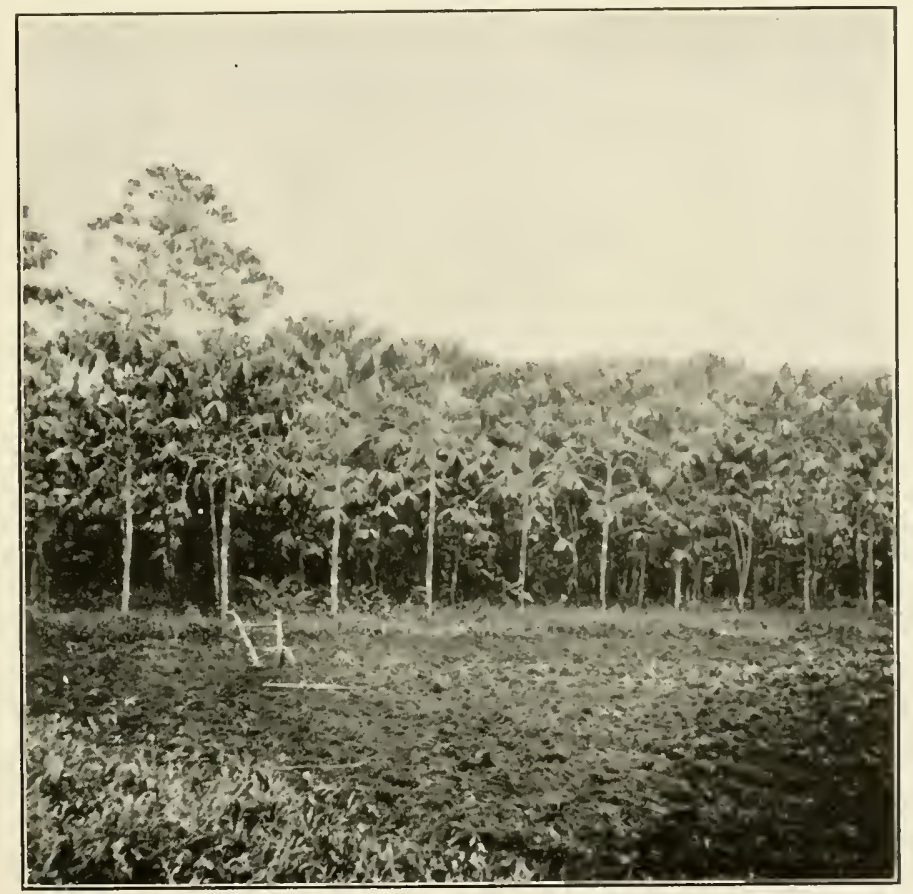

SIM IRON'S RUBBER PLANTATION.

fifty feet above sea level, and as a rule, the soil was very rich and very well drained.

One of the first plantations that we visited was owned by a genial old gentleman from Virginia by the name of Sim Iron. He runs his place himself and has about seventeen thousand trees between three and four years old. His ranch houses were more picturesque than those of the Manhattan, in that they were palm thatched and built largely in the native fashion. During a part of the year the old gentleman has his wife 
on the place with him, and they seem as happy and healthy as if they were rumning a farm in a northern clime.

After looking over the Sim Iron plantation, we visited Daytonia, now the Rubber Grove plantation, where there were some very good trees, although it was explained that the man who started the planatation sold something like two hundred thousand clollars of stock, and spent

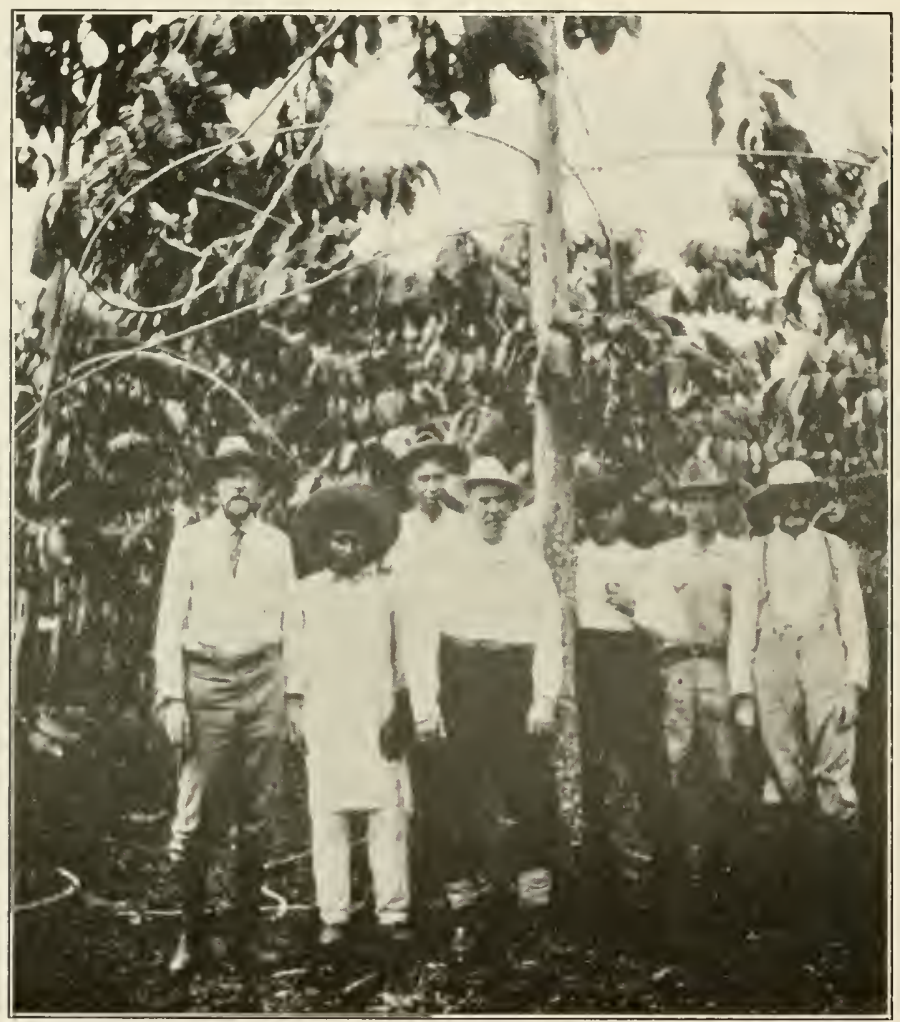

IN THE SIIADE OF A RUBBER TREE.

N Named from right to left: Sim Iron, S. W. Sinclair, J. A. Belanger, Clarles [I, Arnold, Arthur F. Townsend, The Cook, Henry C. Pearson.]

only thirty thousand dollars in planting. He was later prosecuted for frand and was sent to jail in some one of the Lnited States. The plantation was then taken over by a local company. who are getting it into gond shape.

Ifter leaving Daytonia. We visiterl some small private plantations. 
all of Castilloa, which lorsed excellently. Then we returnerl to the Manhattan House for noun breakfast, and in the afternorn walkerl across lots to look at the rubber on the Cukra plantation. Just as we wot there our first real shower came down. That was not any spring rain: it was more like a clondlourst, and kejot us pemed in the honse for nearly an hour. It cleared off, however, as suddenly as it cance on. and then we began to examine the interesting experinents that were lexing carricel on by Mr. Máldron.

He had already begun tapping some of his six-year-old trees. and close to the house where we hat taken refuge from the shower was his coagulating and arying house. In this house were galvanized inom

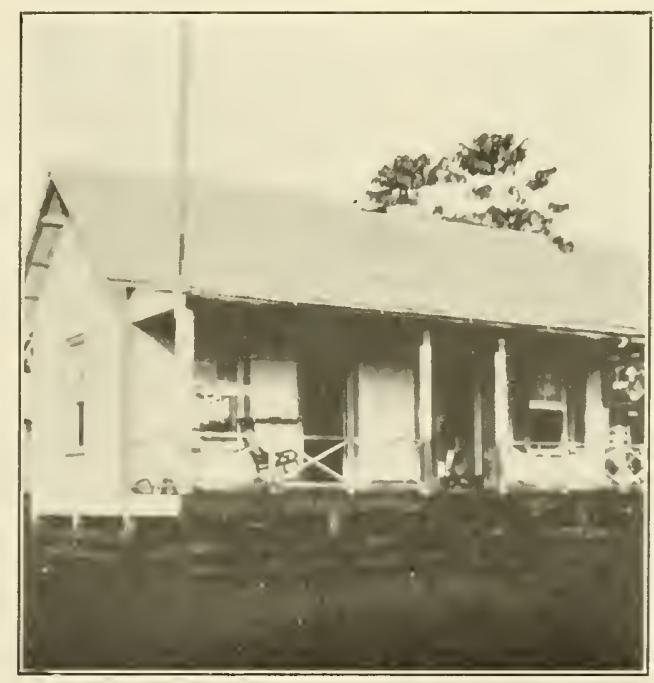

M INHATTAN PLANTATION-MUELIING HOL'SE.

cans holding half a barrel, each filled with later. mixed with water and formaldehyde, while from the ceiling lumg long strips of rubber being air dried. Mr. Waldron used the formaldehyde to keep the later from coagulating too soon, and he washerl out the regetable acids and the allummen by diluting the late.r and creaming it. He found some difficulty in coarulating. and had, therefore. fitted wi) a couple of caldrons close to the house, and was boiling the later. The rubber appeared to be very clean. but a little short. Indeed, Mr. Maldron acknowledged that he thought it was coalesced instearl of coagulated.

From the coagulating house we walked down through the rubber 

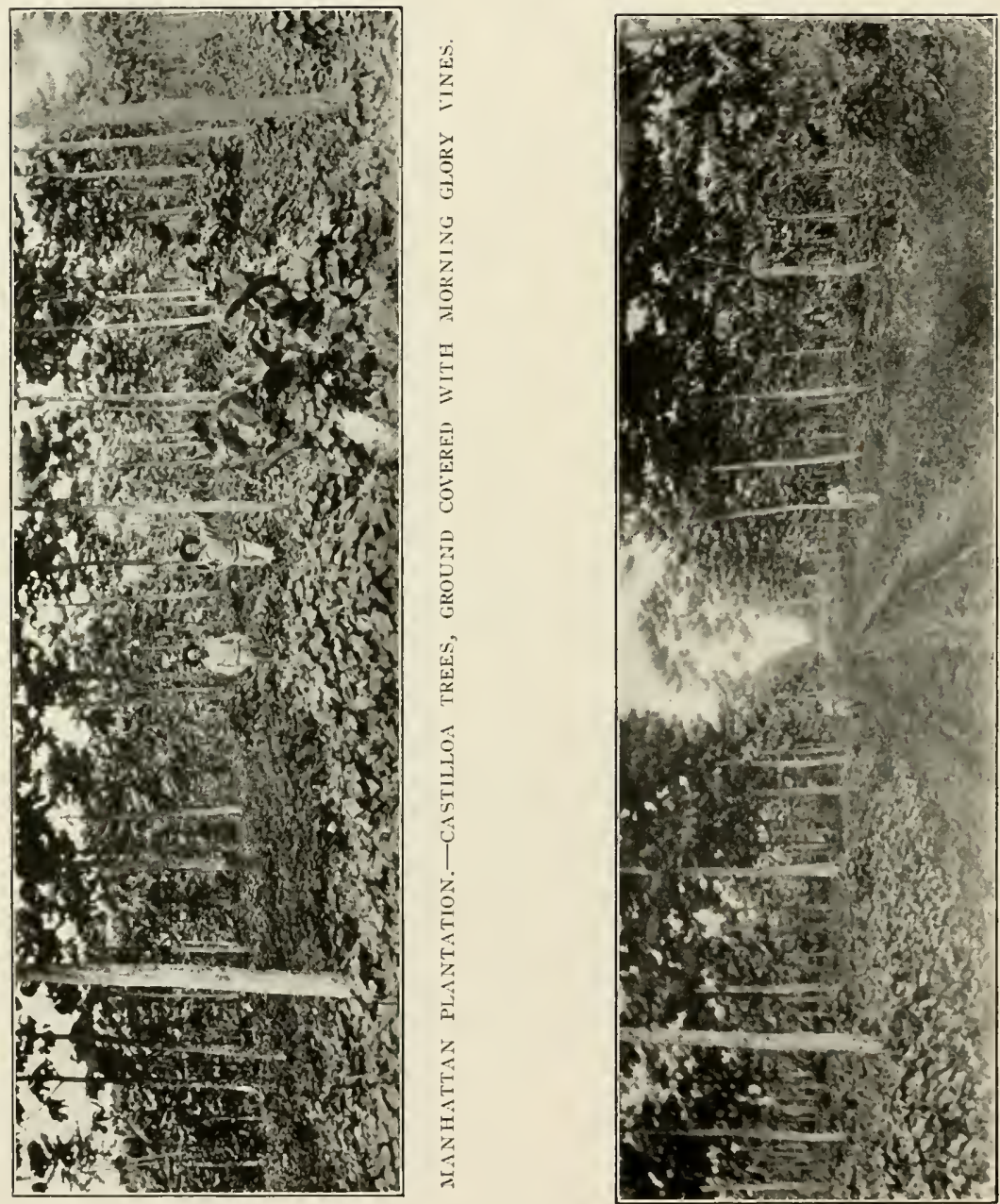
orchard to the trees that were then being tapped. This work was done very carefully and in the most cleanly way, the late. being caught in tin cups of which there were three rows of four cups each, making twelve cups to the tree. After the milk had stopped flowing and the cups had been emptied, a native was sent around witl a spoon to take off the thick creamlike exudation that gathered in the cuts. Is this was taken off before coagulation, it went into solution with the rest of the later without any trouble. Mr. Malchron was getting three omices of dry

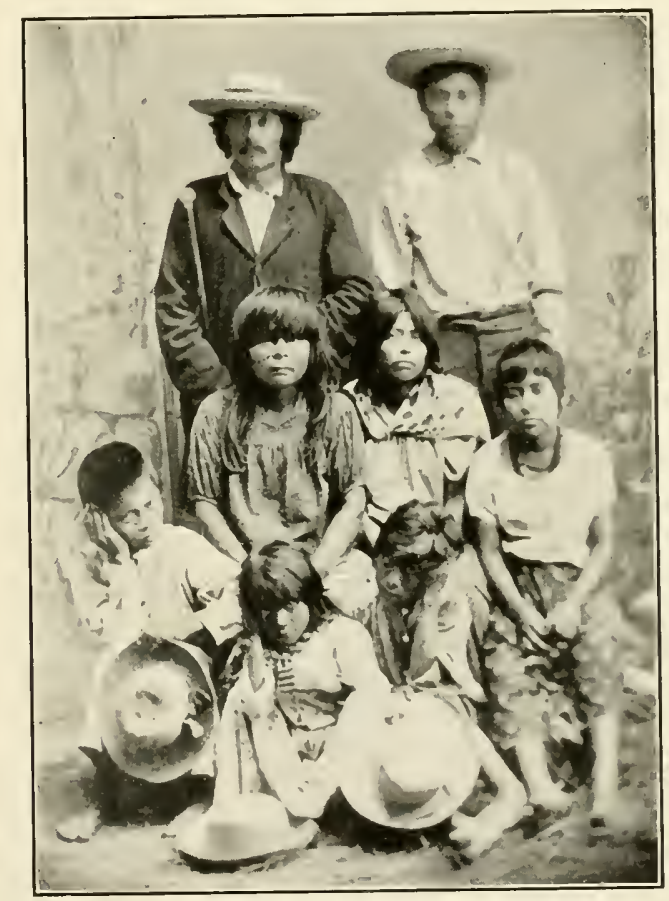

MOSQUTTO INDDIANS.

rubber from each tree and was plamning to tap them a number of times during the year. He talked of tapping by team work through the whole of the dry season, and during the wet season to slip only a couple of weeks during the torrential rains.

We tried the Cevlon tool, but it didn't seem any better than the ordinary knife for this work. The general manager of Cukra, although very much of an iconoclast, and not in the habit of following other people's lead, ackinowledged that much of his tapping and coagulating 
was only experimental, and that he expected before long to work down to a simpler and more practical system. At the same time, he claimed, that cumbersome as his present process was, it proved most thoroughly the profitableness of

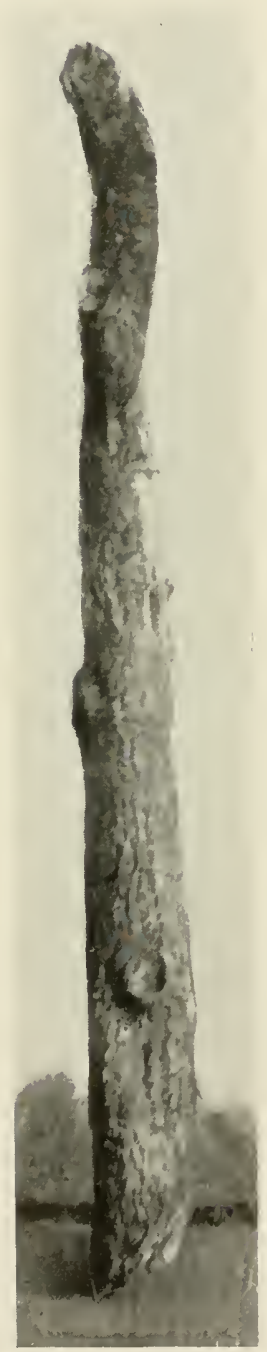

"CAstilloA" STE.I ATT.ICKED BY SC.MLE. rubber planting.

During the rest of our stay on this group of plantations, we made our headquarters at Manhattan, riding ont in varions directions and examining the rubber, and discussing it with various planters. who were much interested in making a success of it. There are in the vicinity, at a conservative estimate, about four hundred thousand cultivated Castilloa trees, the largest single plantation being the Canada plantation, of which Mr. Waldron is manager and chief owner. This plantation has about two hundred thousand trees: next to that comes the Manluatan. with about one hundred and forty thousand. This gromp of plantations lies in the form of an eclipse, abont five miles long and two miles broad.

Ifter having visited the typical plantations, collected samples. and secured all the information possible, the whole crowd saw us down to the Cukra pier, where we again embarked on the Nat. Jr., and started down the river on our way back to Piluefields.

We reached this Americanized city early in the evening, and found that a fruiter was starting for New ()rleans the next morning, and that the governor harl promised to hold it for us, so that we could not miss it. In the meantime, our friends hegan to make it easy for us to leáve the country. One of the first things to be done in leaving Nicaragua is to secure a passport, for which one pays a dollar. Mine described me as being about thirty-five years old and having red hair, but so long as it sufficed to let me out of the country 1 dich't care, particularly as the description of the Importer and the Manufacturer were even less flatterins. I have already mentioned that the custom house at Bluefields is 
situated at the bluff, sonce miles from the city itself, and it was while going over to the fruiter that was to take us to New Orleans, that we saw a very curious instance of the peculiar concessions that are held by various companies. It seems that a steamer which was mot one of the elect had come down there for a load of bananas. In other words, it didn't belong to the company having the navigation concessions. It was, therefore, not allowed to go up into the rivers or lagorns but, not to be beaten, the steamer's captain sent up to certain planters who, promptly despatched a huge scow load of bananas to the bluff where the steamer lay. The govermment catsed the seow to be laid alongside of its wharf, and proceded to discuss the unlaw fulness of the proceedings. While this discussion was going on, something like a hundred soldiers marched onto the gunwale of the scow, which careened it just enough

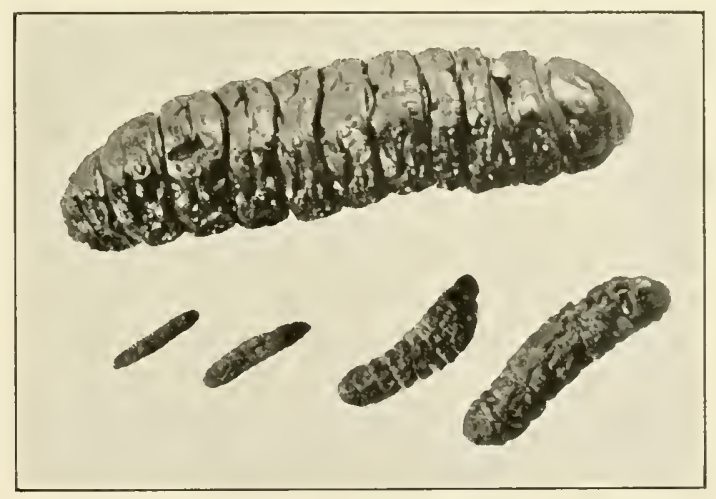

L.IRT.AE OF C.ISTILLOA BORER.

to cause the water to flow over the low bulwarks and sink the boat, bananas and all.

I tried to get a photograph of the sinking scow, but was deterred by a gentleman who said that I might get in trouble with the customs officers, and get my stuff held up if I gave evidence of being too active a partisan. This was no idle dream. for I lad trouble enough with the officials anyhow, although I was not taking anything out of the country except what I had brought in, with the exception of a few samples of rubber and some Castilloa twigs that I was taking home in order to discorer by what disease they were attacked.

Speaking of diseases of the Castilloa tree. I noticed in a yard surrounding one of the plantation houses, that numbers of trees were 
affected by scale, some of them quite badly, the insect appearing to have practically destroyed the lactiferous tubes, so that the outer bark presented a curious shrmken appearance. This scale, as far as I was able to observe, only appeared where neither undergrowth nor weeds were in evidence round the foot of the tree. All of the trees thus affected were uprooted and burned. I brought samples of the stems back to the United States, however, and through the courtesy of the experts at the Connecticut Agricultural Experiment Station at New Haven, and the Bureau of Entomology at Washington, I was able to identify the disease and also to discover simple remedies. The reports of the two entomologists follow:

DEAR SIR: Your letter with specimens has been referred to me. The tree scems to be attacked by two species of scale insects, the large brown one is a Lecanimm, and the small, glassy, greenish yellow one is an Astcrolecanium. We do not have the literature by which I can determine them specifically. From a knowledge of simliar species found in this part of the country. I should expect that a thorough spraying with kerosene emulsion or whale oil soap would destroy them, though of course experience is needed to know just how strong to make the mixture. I should try some of these made in the proportion recommended in published bulletins, and if it dici not kill them. I should use somewhat stronger mixtures.

\section{Very truly yours.}

IV. L. Britton,

State Entomologist. The Connecticut Agricultural Ex-

perimental Station, New Haven, Connecticut.

DEAR SIR: The scale insects upon the twigs which you sent represent the akee fringed scale (. Asterolecminm pustulans), and Lenaciodiaspis rugosus (?). This Asterolecanium is very common and very injuriots in the Nest Tudies. It works principally upon akee, oleander, fig, and hibiscus. Mr. Maxwell-Lefroy, the government entomologist to the West Indies, in pamphlet series No. 7 of the Imperial Department of Agriculture for the West lndies, recommends kerosene emulsion for the control of this insect. His formula and method of preparation is as follows: "Terosene emulsion: Dissolve one-half pound of hard soap in one gallon of water: ard two gallons of kerosene to the hot liquid, and immediately churn with a syringe or force pump until the mixture becomes creamy. This is a stock solution. Make up to thirty-three gallons. ['se only rain or soft water." 
The kerosene enunlsion preparation can also be applied for the Lecaniodiaspis, of which only a few specinens were fonnd on the twig which you sent.

$$
\begin{aligned}
& \text { Yours truly, } \\
& \text { li. H. CHITTENDEN. }
\end{aligned}
$$

Acting Chief, Burean of Entomology, Washington, D. C.

Another possible enemy to the Castilloa that the alert planters were seeking information about, was a wood borer which attacked the tree where the self-pruning branches broke off, and oceasionally where the

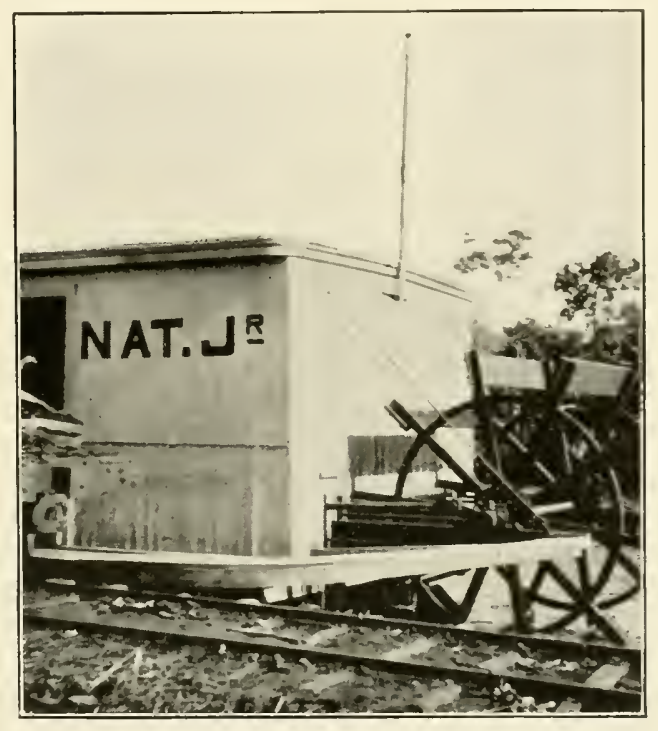

STERN OF "NAT, JR."

bark was cut or wounded. The laria of the insect are large grubs, that after penetrating the outer bark burrow upwards inside of the cambinm, and then straight through the wood, completely loneycombing it so that the trees break short off when very little wind comes. This does not always kill the tree, but it sets it back appreciably. These borers appear to be most active during the months of June and July. The planters. for a remedy. were using a mixture of tar, kerosene oil, black oil and sulphur. This killed the grub if it tonched it, hut it was very difficult to reach it because of the length of the burrow. A suggestion for keeping the borers ont was to have a gang of men constantly going 
over the trees and tarring all cuts and the sockets left by the dropping off of the temporary branches. This, however, would be very expensive and hardly practical. I was able to secure a number of specimens of the larice, and the Bureau of Entomology at Washington decided that they belonged to one of the large moths, family Cossida. Their report was that they knew little about the work of this moth, but that the best way to kill the borer was to inject a few drops of carbon bisulphide into the burrow with an oil can, closing the orifice with a little wax. The fumes of the solvent would then penetrate the lower part of the burrow and kill the grub. Professor John Barlow, of Kingston, Rhode Island, however. reported that instead of a moth it was probably a beetle. $\mathrm{He}$ suggested the same treatment for the destruction of the grub as the Bureau of Entomology at Waslington. In this connection, it may be well to recall that sometime before this an anonymous writer reported that a beetle, the Aconsymus longimanus, was troublesone in Nicaragua just in this way-that is, laying eggs in wounds in bark of the Castilloa, which developed into borers and greatly injured the trees.

The fruiter on which we finally embarked was a Norwegian of about seven hundred tons, and carried ten thousand bunches of bananas. As we were the only three passengers, we took possession of the bridge. and also of the captain's quarters, and lived high in everything except food. We went out in the face of a norther, and ran into one after another during the whole passage. The boat had no refrigerating apparatus, and to save the fruit both the fore and after hatches were kept wide open, and it was a constant matter of wonderment to me that some of the big green seas didn't topple over our bow and swamp us, but they didn't, and we sailed on by Cape Gracias a Dios, through squall after squall, the temperature all the time in the eighties, and finally, missing the delta of the Mississippi by a wide margin, ran almost to Mobile before we got our bearings. We finally got right, however, and went up the Mississippi and landed in New Orleans just in time to enjoy the fireworks with which they usher in Christmas Day. 
A GLimpse OF RUBBER PLANTING IN COSTA RICA 



\section{A GLALPSE UF RLBBER PLANTING IN COSTA RLCA.}

The First Sight of Costa Rici, the Banina Repubiac-how the Fruit is Shipped by the Uniten Fruit Company-Enterprise of the Nitive Costa Rican-The City of San Jose axu It's National Theatre-d Plantation of One Hundred Thousand Castilloas-Other Plantations of Lesser SizeWatery Latex-Sone of the Conutions Necessiry to the Success of the Castilloa.

UR first sight of Costa Rica came at five o"clock one morning. when we sighted the low-lying city of Port Limon with its background of far away mountains. It was nearly eight oclock before we made fast to the pier, and even then it took us some time to have our luggage weighed and the customs paid. The time came finally.

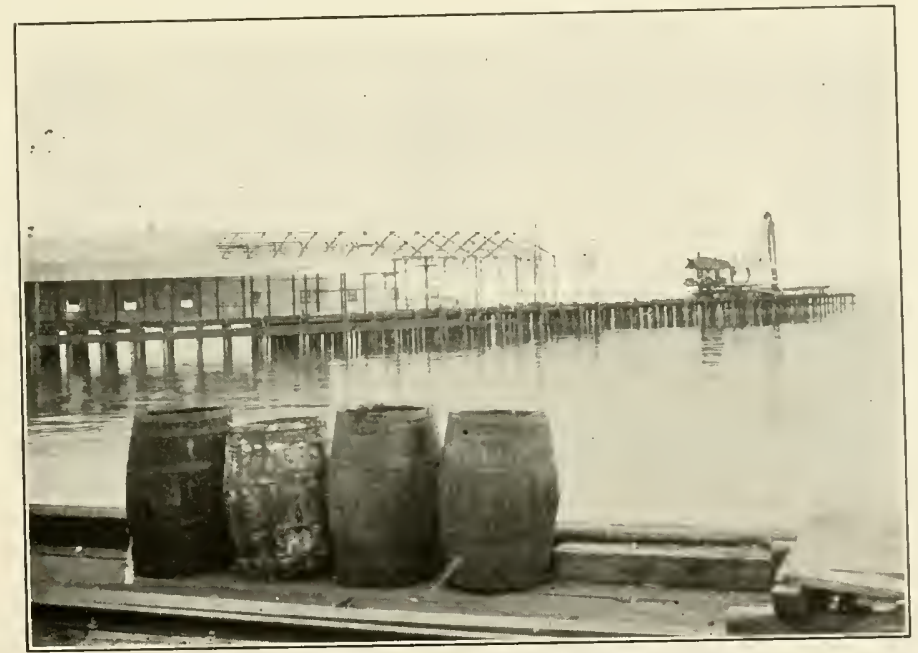

WHARF IT PORT LIMON, COSTA RICA.

however, when we were free to walk lown the long pier, through the gates, and explore the town.

Not only is Costa Rica justly called the Banana Republic, but Port Limon is a banana town, and we fully appreciated it when we saw the train loads of green fruit run out upon the piers, the huge bunches dumped upon rubber convering belts and carried smootlyly into the holds of the waiting steanships. The town, moreover, harl an alert air about 
it that was in no way sugestive of typical Spanish America. It had no very pretentious buildings, with the exception, perhaps, of the office building of the ['nited Fruit Co., but it boasted two hotels and the "Gem Saloon," where all the men congregated, and besirles that, almost everybody spoke English.

It ten oclock in the moming, the thermometer stood at $90^{\circ} \mathrm{F}$., the air reeking with moisture, and the sky covered with evil looking clouds. Nevertheless, the streets were thronged with a most vivacious mixture of porters, fruit sellers, soldiers, Jamaica negroes, Chinese, and native Costa Ricans. At 10.30 we boarded the train that was to take us to the interior, and rode for twenty miles through a flat, swampy country where

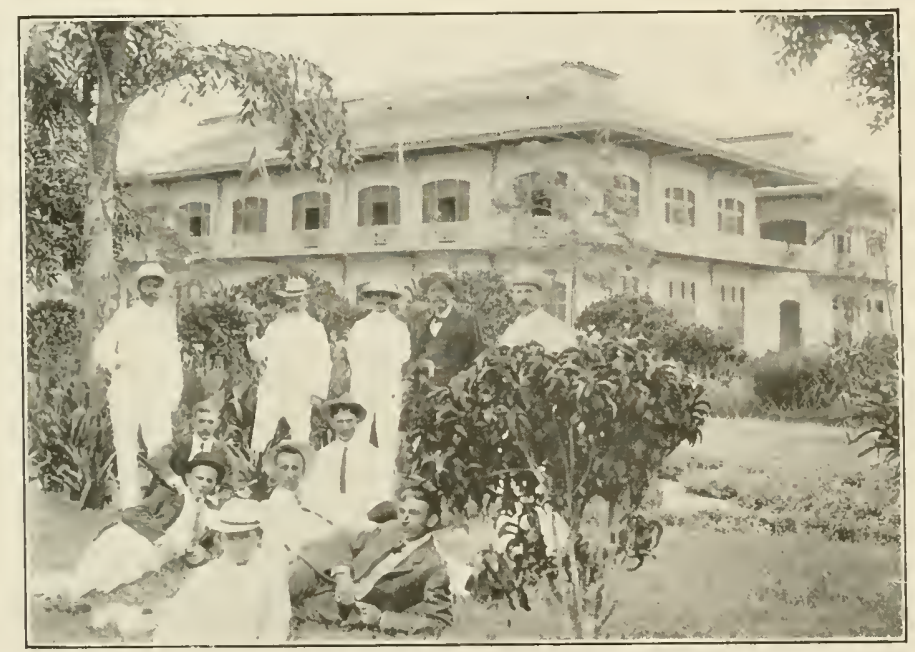

UNITED FRUIT CO.'S COMMISSARY, PORT LIMON.

even the native Costa Rican cannot live, but where the Jamaica negro flomishes and waxes fat. At intervals along the railway were little huddles of huts built on stilts to keep them out of the hlack mud, roofed with corrugated iron or palm leaves. and full to overflowing with the elony suljects of his Majesty King Edward YII.

The heads of the families that called these shanties, homes, were very largely laborers on the hanana plantations of the Lnited Fruit Co., and when it is remembered that out of Port Limon come some seven million bunches a vear, it is easy to appreciate how large a force of men is neederl to cultivate, cut, and ship this great crop. It is clamed that there are eleven thousand Jamaica negroes on the plantations near Port 
limon. For them the Luited frute co. provides lospitals, keeping out two per cent. of their wases for medical attendance: and yet. in spite of black fever, gellow fever, musquitoes, and snakes, there is not a great anomut of sickness anume these laborers. And if one can judge ly the appearance of the people, their home life in their little tin-rooferl shacks, crowded with pickanimnies, mangy dlogs, momkeys, and parrots, shows a greater measure of content than is to be fomel in the majority of settlements more farorably locaterl, and populated loy those who have a thousandfold more to make existence tolerable.

Is the train energed from the palnetto swanus, it ran through sonse magnificent banana plantations, the trees growing rankly from ricls

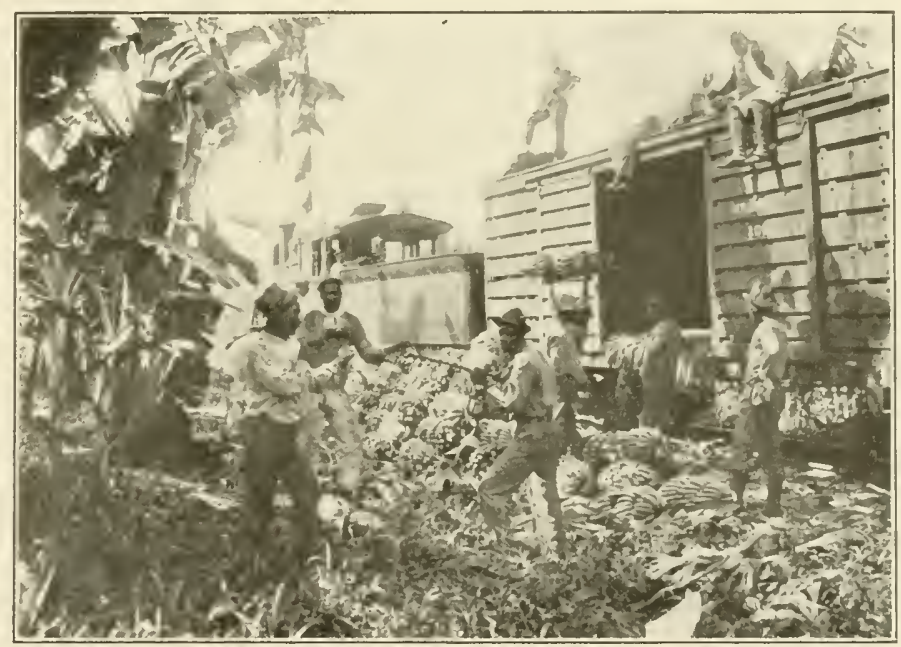

LOIDING B.INANAS ON I TRIIN.

allurial soil and the bunches of fruit heing often five or six feet long. and weighing over one humbled pounds each. The railroad, by the way. over which we were traveling. was built through the enterprise of that well known American. Mr. Minor C. Keith. who was also the creator of the sreat Cnited Frutit Co.

After a time the roal began to ascend and the scenery became more and more beautiful. Nearly the whole of the distance up to the city of San José. the way lay along the side of a range of monntains, and ran parallel with a rapidly rushing river. whose white water could be seen oftentimes for miles. As we got mp into the higher comntry, the home life of the Costa Rican began to be apparent. 
Everywhere through the broad valleys and up the mountain sides could be seen cleared farms, in many cases fine plantation houses and great coffee estates. The native Costa Rican is perhaps one of the most enterprising and independent of all the Latin Americans. Nearly every man owns a patch of land and cultivates it. The better class speak English and are very friendly to Americans, welcoming them to their country with a manly, prideful air that is extremely taking.

In the meantime the Ferrocarril Costa Rica was slowly but surely getting us up toward San José. The English locomotive was having a tough time of it with the steep grades, and it seemed every now and then as if the pull would be too much and that the heavy train would slip

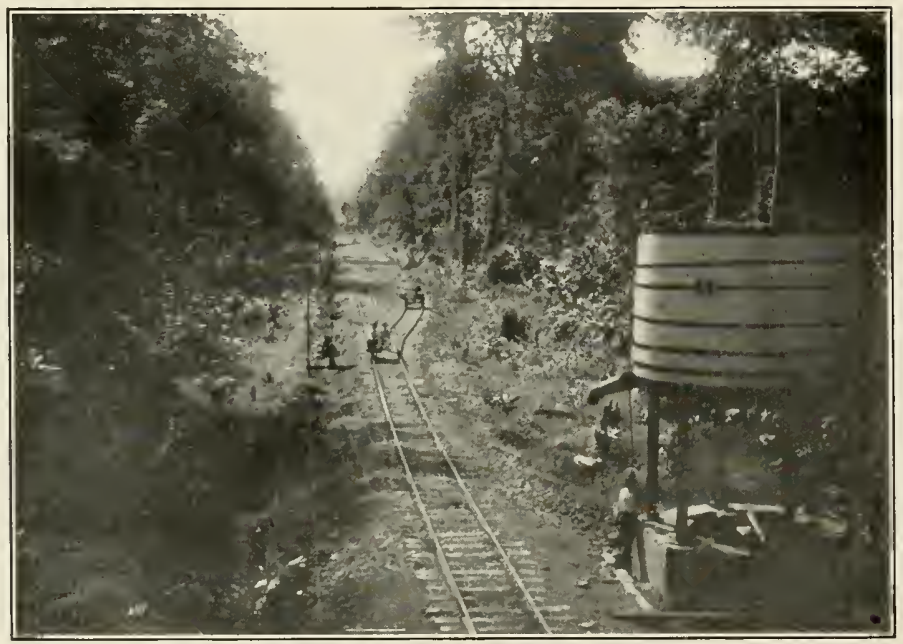

TEN MILES OUT OF PORT LIMION.

back down into the valley. The slow progress, however, gave us every opportunity to examine the track with its iron sleepers, to see where various great landslides had time after time wiped out the railroad and even dammed the swift flowing river: and to enjoy the wonderful semitropical luxuriance of the giant trees festooned with vines and studded with epiphytes: to look down into deep gorges, up the sides of steep mountains, and across broad and fertile valleys, so photographed the scenery in one's mind that the snail's pace of the train was not only not objected to, but was most welcome. At intervals all the way up were to be seen Castilloa trees, many of which had been tapped in the brutal native fashion, which amounts almost to girdling. At about fifteen 


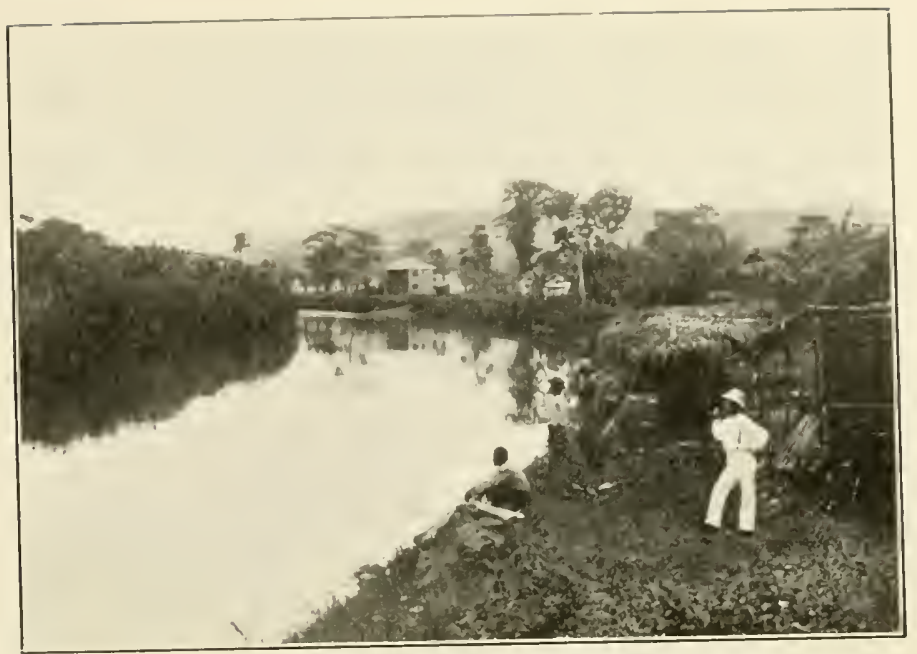

(HIRRIPU), SHOWIXG MINOR C. KITI'S PL.KE.

humbled feet altitude the rubler trees began to apparar less frequently: and when the aneroid read two thousand feet, they disappeared entirely.

After reaching an elevation of some five thousand feet, we descenderl a thonsand feet, and finally reached San José. The city is stuated in the midst of a broad and fertile valley, and is semi-tropical rather than tropical, being surrounded hy buge fields of sugar canc, corn. and growing nost of the well known tropical fruits. San José itself is a surprise.

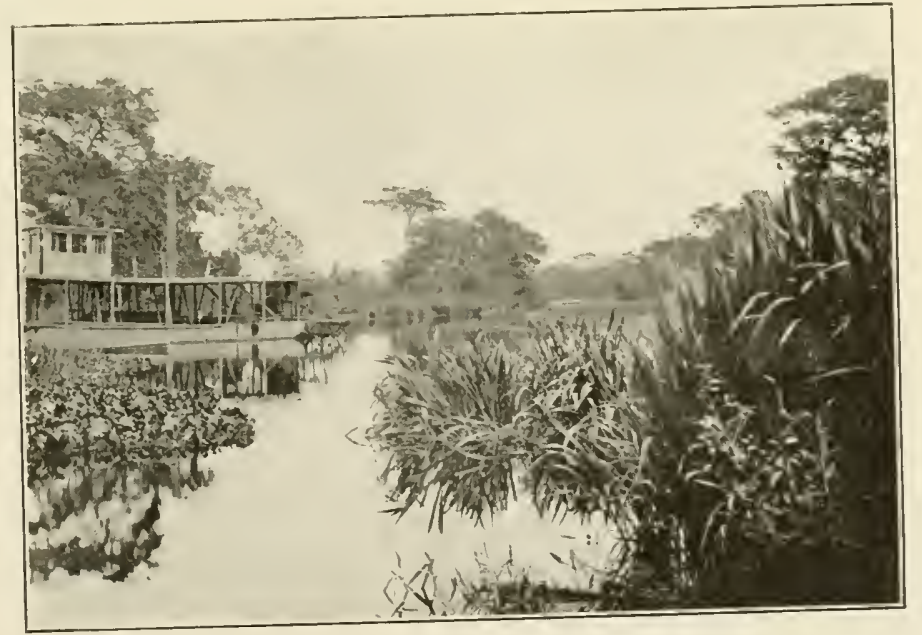

RIVER SCENE XE.IR PORT LIMON. 
With its well-kept streets, its trolley lines, electric lights, fine stores, and alert looking inhabitants, it is more like a modern American city than anything else. Although it contains but twenty-four thousand inhabitants, it gives one the impression of a city of double that size; partly. perhaps, because the buildings are nearly all two stories only, as the frequent earthquakes do not invite the erection of skyscrapers. The single unpleasant feature is the open sewage, which is said to invite typhoid. Asile from that, there is practically no disease, the climate being equable, and the people, except on rare occasions when they take too much aguardicute. give the military police little trouble.

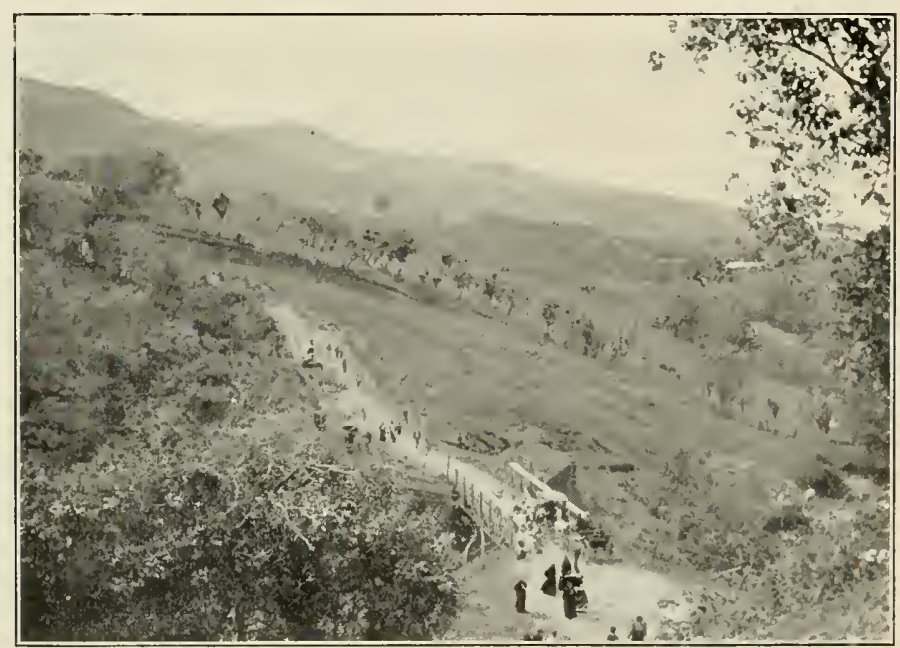

MUUNTAIN ROAI NEAR SAN JOSE.

Almost from the first of onr landing in this country we heard of the magnificent National Theatre that San José possessed. The Latin American lescription of it made it more elegant and on a larger scale than anything in New York or Lonclon. For this reason. the first view of it was a bit of a disappointment. It certainly was heautiful architecturally, and its decorations were most elaborate, but it is a question if it would hold more than a thousand with comfort. Nost of the decorative work was done ly artists who were brought from Italy, and some six hundred thousand collars gold was spent upon the building. In the foyer on the beatiful inlaicl flow were some of the mest worgeous rubber mats that I have eve: seen, in red, white, and hlue, with green leaves, yellow trumpets, golden 


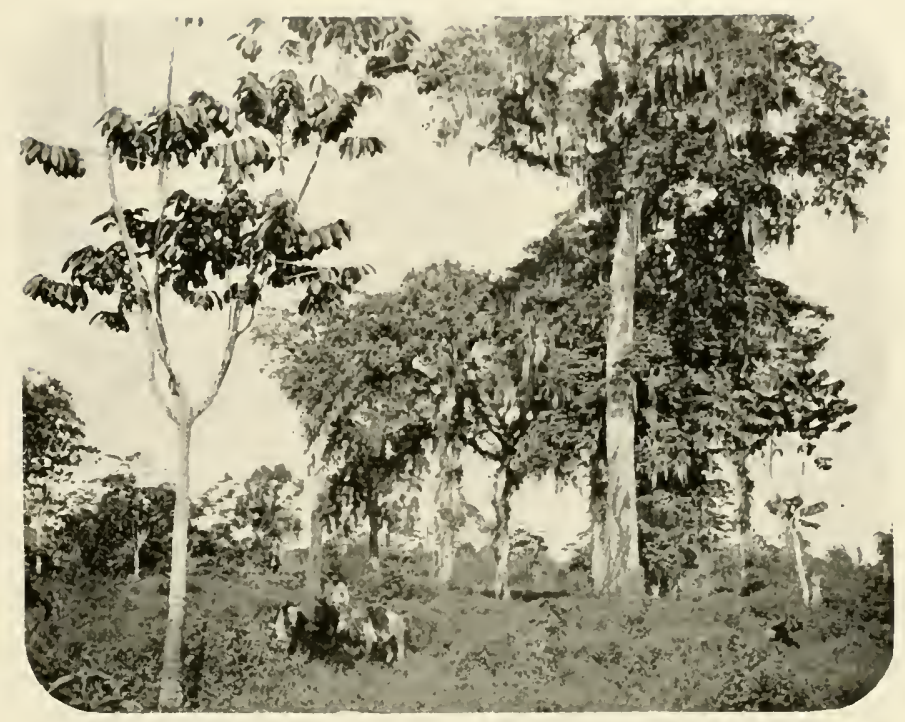

TYPICAL COSTA RICAN LANI) (LE.AREI) FOR P.ASTLRE, WITH CISTILLOA LEFT STANDING (ON THE LEFT.)

harps, etc., and they bore the imprint of the well known firm of Pirelli \& Co., Milan, Italy:

The city has large wholesale houses, chiefly in the hands of the

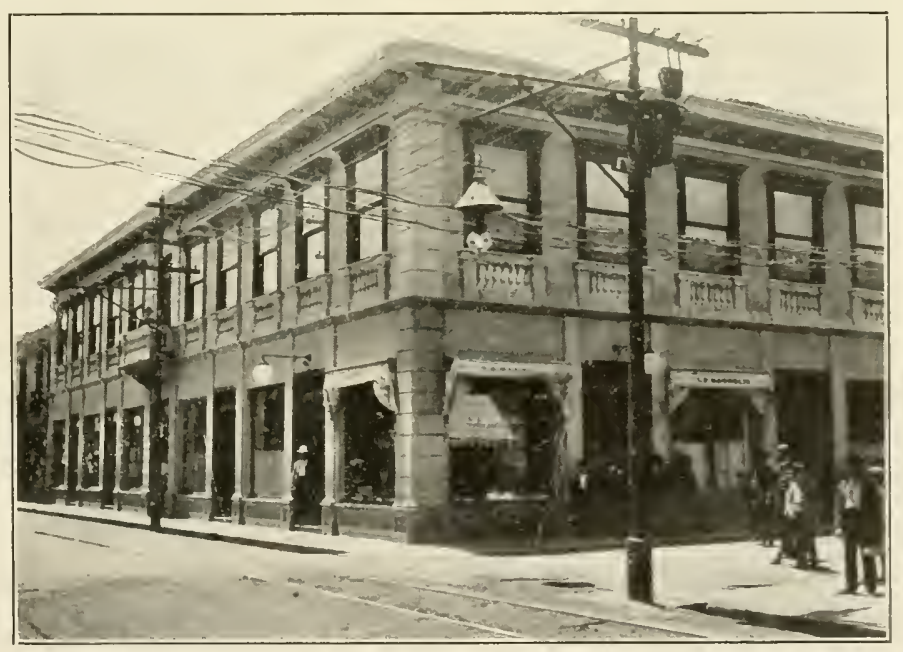

SCENE IX STREET IN SIN JOSE. 
Germans, and substantial banks, the country being on a gold basis, with the colon as a unit of value, worth forty-six cents in American money. The population of the country is three hundred and forty thousand, none of whom are Indians. Spanish is the langmage in general use, but almost everybody understands English, and it is a lelight to mingle with the people, for they have none of the sullen air so prevalent in certain parts of Spanish America.

During our stay in the country, we put up at the Hotel Imperial. where we had comfortable rooms and enjoyed an excellent table. Is a matter of course, we askerl many questions about rubber culture, but from the natives or the resident Americans we developed little informa-

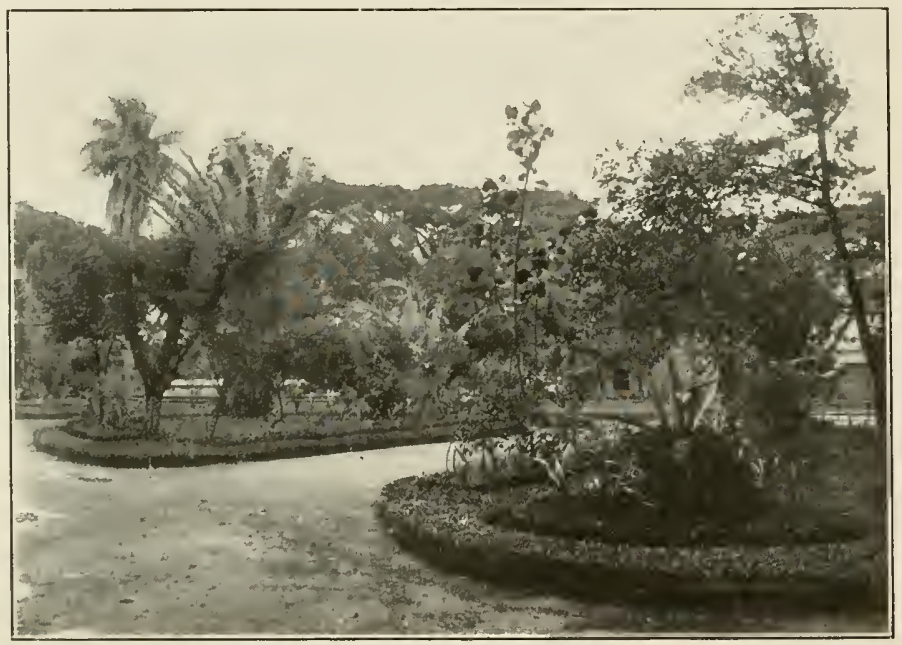

CENTRIL PARK, SAN JOSE.

tion. One of the latter explained it by saying that in that country at the present time bananas were the whole game, because they gave quicker results and had behind them the support of the Lnited Fruit (i). who were perfectly willing that the planters should make a goon thing out of their fruit. One native explained the lack of intestest in rubler planting by telling us solemnly that rubber seeds planted by man would not develop into productive trees. He said that natures way of distributing the seeds was for the hircls to eat them in order to get the sweet pulp with which they are surrounded, and mingled with their croppings, the seed grew into a tree that was a rubber producer. If it rlicl not got thromgle this prejaratory process, it amounted to nothing. 


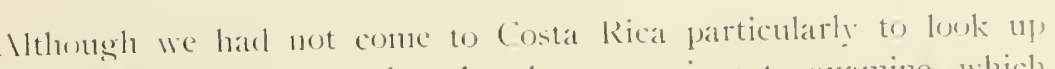
rubluer, there was one plantation that I was anxious to examine, which was said to contain over one humbled thonsand Castilloas, most of which had been interplanted with bananas. These trees were three or fontr vears old, and planted by one who had han nutsels experience in tropical forestry throughout (entral America. The Importer was su pleased with the eity of San fosé and so relieverl to get out of the heat of the lowlands that he deciled to sta! there, while the Nanufacturer and the writer took another plunge into the hot country. We, therefore. left lime for a further exploration of the city, and getting up at ra! loreak, boarled the train and retraced our steps, slicling slowly dowmwarl

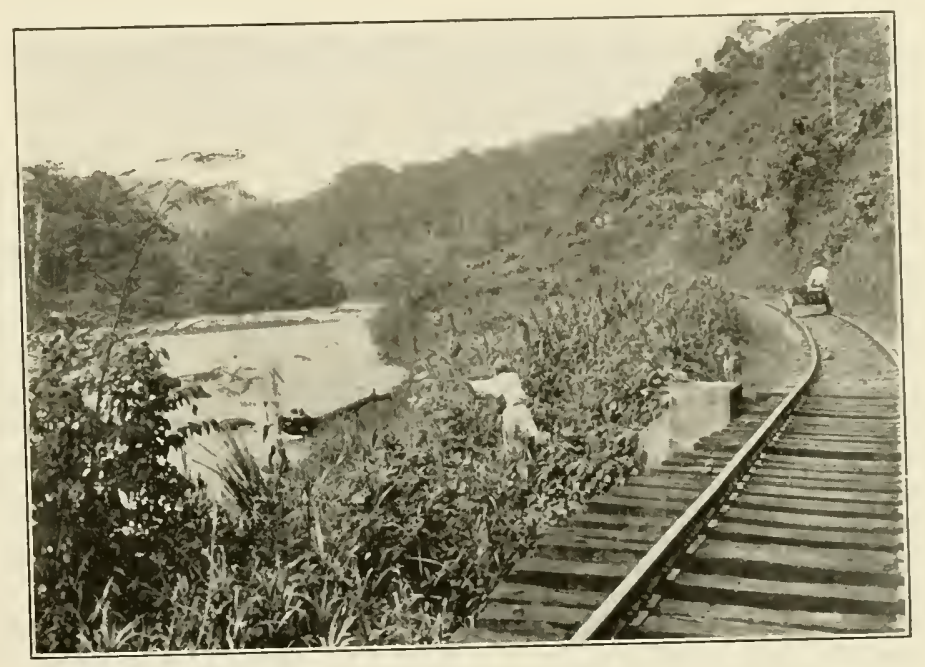

R.ILROAII ON THE WIY UP TO SAN JOSE.

for hours, until we reached the lower levels. The jommey downmard was even slower than the climb, as the engineer must be on the loukont constantly for falling rocks and for landslicles, and I fancy he is also particularly careful not to let the train get awa! from him, which, with the number of cars and the heavy freight carried wonld seem to be a not mnlikely happening. We therefore enjoyed afresh the magnificent scenery, and hefore we got down to the tropics, the lorely, springlike weather.

Reaching the plantation, we were warmly welcomed by the planter in charge, who got us horses and took ns over the planting. It was the dry season and there had been $n 0$ rain at all for five days, but the ground 


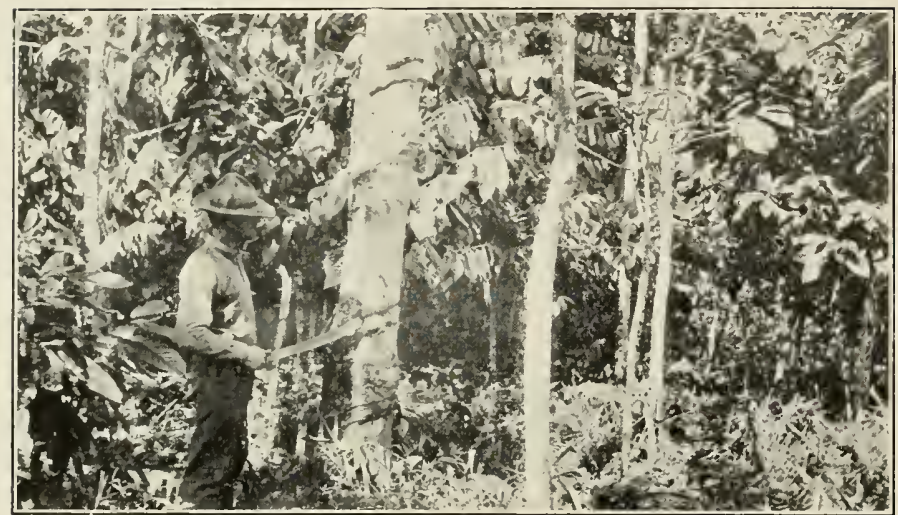

NATIVE RUBBER TEN YEARS OLD SURROUNDED BY PLANTED RUBBER AND

CHOCOLATE.

was exceedingly soggy and wet, and while the bananas were apparently very thrifty, the rubber did not lock as well as it should. The leaves, to be sure, were shedding, which made the trees look their worst, but the few trees that we tapped gave out an exceedingly thin milk, more like skimmed milk than cream, containing, for a guess, not over twenty per cent. of rubber. It is possible, of course, that at the end of the dry season this might thicken up appreciably and be worth extracting, but unless that happened, they would hardly pay to tap.

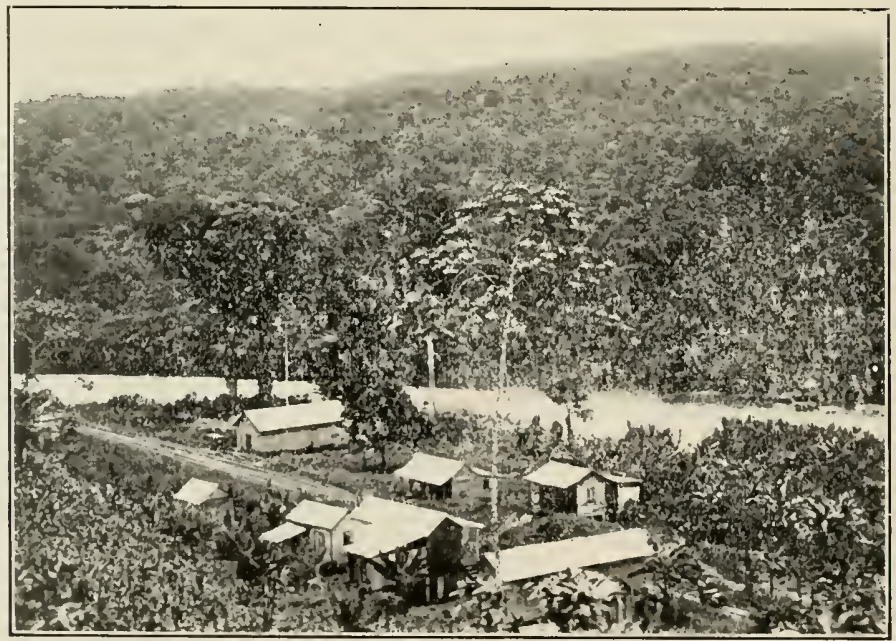

TYPICAL LOWLANI TOWN. 
In this comnection, a chat that I hacl 11 ith . Mr. John M. Keith, the

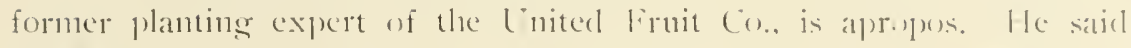
frankly that in that part of Costa Ricat he diol mot think there was much land that was available for Castillog growing: that it wats too wet: amel that he had discovereed that wild Cistilloets that grew in wet places gatre so thin a later that the rubber was not worth gathering. My frienel. the planter, had, while l was in Xew York, told me of another type of planting that he had done, by clearing wide pathways through the forest and planting (astillous so thickly that they touk entire possession of the gromul. With some little troulle we finally located two of these plantings, and they settled in my mind forever the practicability of this

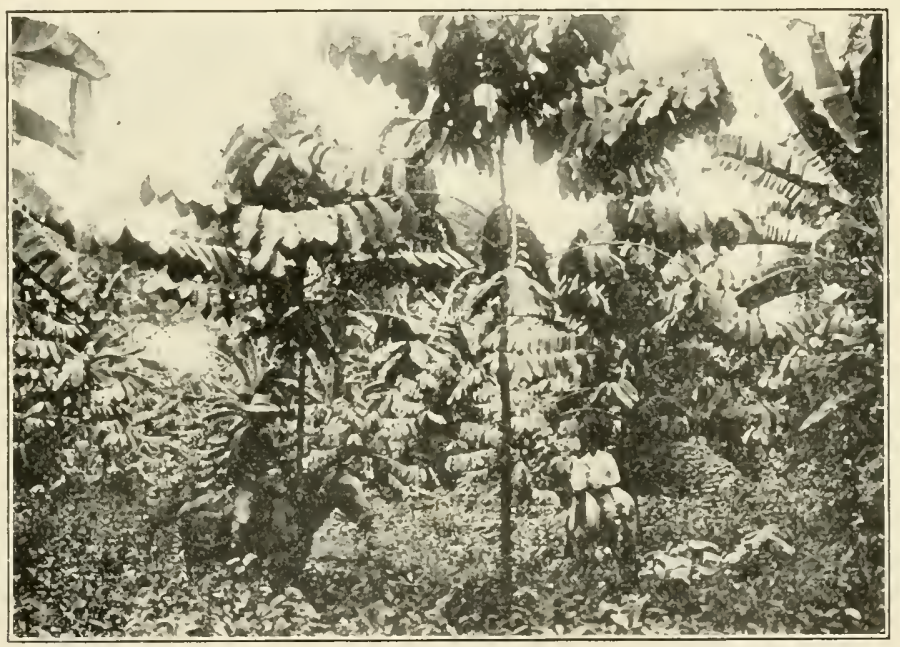

KLPLER ANI) R.INAXAS.

sort of cultivation. The Castilloas har grown like weerls, but they lonked more like fishpoles than rubber trees. liy cutting ont some of then and siving the sum a chance, no doubt something could be done. but unless some such measures were instituted, it would be vears before the tree trunks would have bark surface enomgh to (o) anything at all."

That the trouble with the first planting was not due to the presence of the bananas was proved by a look we had at a small plantation run by a German. where the ground was mucl better drained, and where the trees looked stocky and thrifty. We were also tolil that on the Northern Railway on some of the uplands, the planters were putting 
Castillod in land that had formerly been nsed for bananas and were getting excellent results.

All of this leads wp to what I think I have before written, that a deep, open soil, particularly one that cakes at the surface a little and in which there is no chance for standing water, or nothing more than a very brief inumlation, is what the Castillon calls for.

The interest in the planting of India-rubler in Costa Rica clates back some twelve or fifteen years. As early as 1892 it was reported that the wild trees wear the cities and along the coast had leen practically exhausted. and that what rubber was gathered came from the more remote valleys. In that year the amount of rubher that cance out of the country was a trifle orer six thousand dollars worth, less than half the

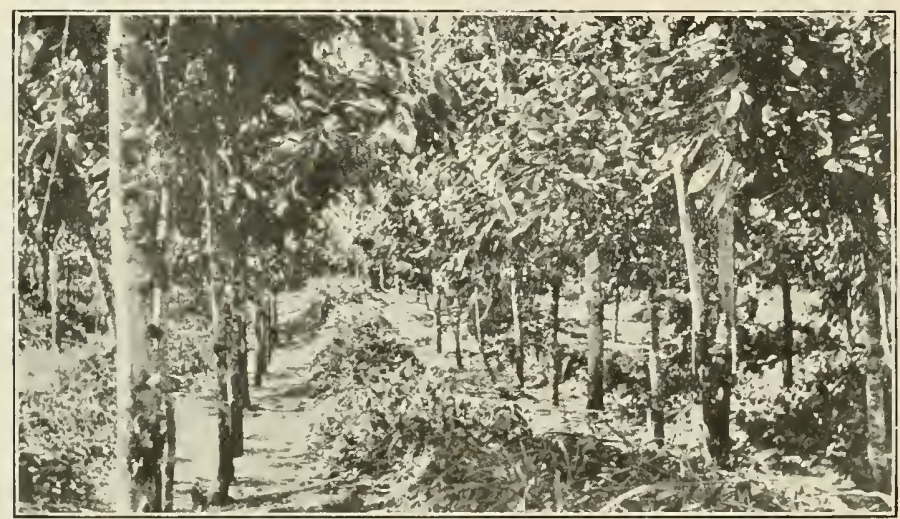

RUPHER ANI CO:IO AITERNATIXG, SIUIING METHOI) UF CLEINING.

amount shipped the preceling sear. It was about this time that the government legan to take an interest in the cultivation of rubber ancl passed laws against tapping the wild trees, and also offered prizes-cne for eight thousand dollars and another for five thousand dollars-for the hest plantations of Castillog rubber. Soth of these prizes were taken in IEgt hy Minor C. Keith, who installed two plantations near l'ore Limon, the trees, some twenty-five thousand in number, being planted with hananas and about one hundred and fifty rubber trees to the acre. It the tinle the prizes were awarled the trees were said to be eight or wine years old. When the writer visited Costa Rica, no recorel of them could be foumd, although they should have been somewhere about twenty years old, and certainly big enough to tap. The gossips of the country 
appear to believe that so much quicker profit cante to the planter through hananas that the rubluer plantations were sacrificed to that industry.

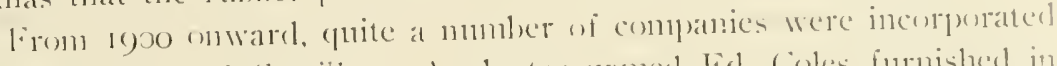
for the planting of Ceastillog. A planter named Eel. Coles furnished in 19) 02 a list of eleven planters who had put in rubler, all the way from ten to one humbled acres. Some of these plantations, if they had heen eontimed. Would have trees that should be at the present time proslucer-

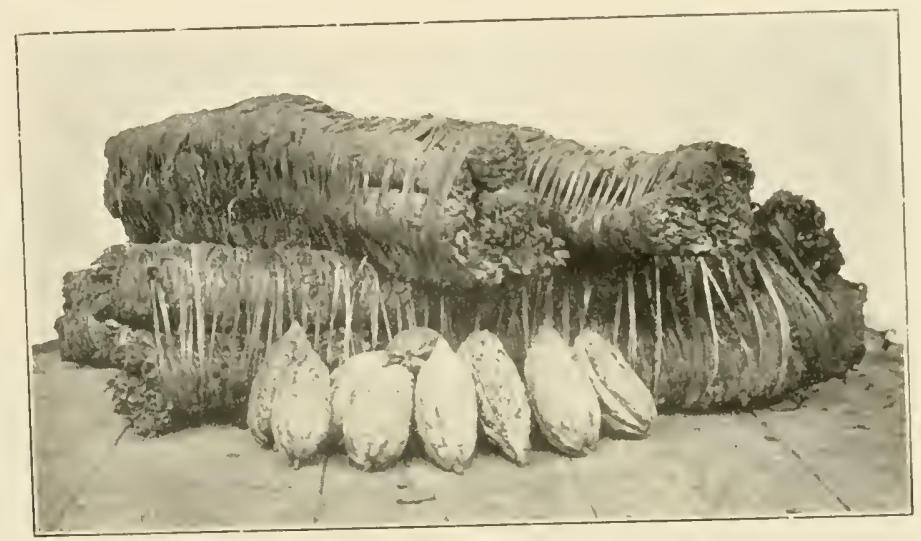

(1) IO PUIS ANI SCR IP RUDPER FROM WILD TREES.

of rubber. The fuestioning of either natives or foreigners on the gromed elicited rery little information: abent all they seemed to know or care aloont was bananas. From an American planter. howerer. we leamer that Messis. Hoffenstadt and Gillet, of Banco de la China, have a plantation. where they lately tapped six hundred Castilloas which were six or seven years old, getting a pound of rubber from each tree.

The correspondent also mentioned an American family named Hogan who were planting rubler at the mouth of the Tres Amigos Rirer. which was the beginning of the Costa Rica Development Co.. with headenarters at 1 os Angeles, California. The officers of this compan! made arrangements for us to visit their plantation, but that meant a call at Greytom. Nicaragua, to reach the Tres Amigos River. but we found that to be impossible. This company have twenty-five thousand trees, a little over three years old, and about fifteen thonsand two years old. which from the photographs that we secured appear to be in a most excellent condition.

In this comnection it is interesting to note the activity of Mr. Th. F. Koschney, an old time settler on the San Carlos River, and one who 
has studied the Castillou carefully. While not a botanist in the strictest sense of the term, his description of the varities of the Castilloa is of distinct value. He divides the Castilloa of Costa Rica into four species. the white, the black, the red, and the "tumu," the first three being all varieties of the Castilloa clastica. Botanists so far have not followed his discrimination carefully, and it is a question if rubber planters have made any distinction, nor has it been proved necessary. Of course. it would not pay planters to raise "tunu" gum instead of Panana rubber, but so far as we know, no such planting has ever been done in Costa Rica, or, incleerl, anywhere else. 
EXPLORING FOR CASTILLOA

RUBBER IN PANAMA 



\section{FIRST LETTER.}

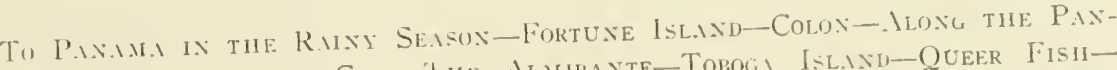

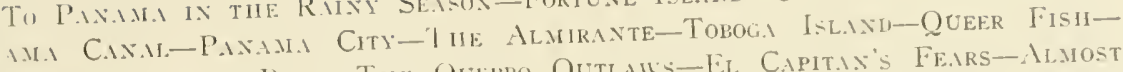

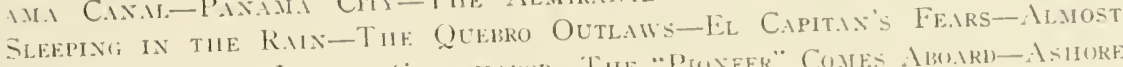

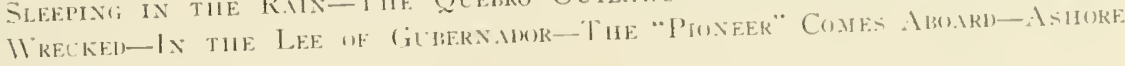
IT L..IST.

I

T was decidedly against my better judgment that I fomm myscli cu route for Central. America in May, due to reach the infant Republic of Panama during the rainy season. and when the yellow fever might be too easy of acquisition. Nerertheless. there I was. a passenger on the Allimea, with two fellow adventuress, while a third was waiting onr arrival in l'anama (ity. The exploring party consister of four-the "Prospector," a well known mining engineer: the "sont," then in Panama, getting together supplies, engaging guides, and chartering a schooner: the "Commodore." and the writer. II task was the examination of some eight bumdred square miles of wild lands, privately owned and lons forgotten.

The royage to Colon was meventful, but enjoyable, although it wrew wamer each day, and sicle awnings and wind scoops told of increasing nearness to the tropies. In dne time lirel Island Rock was sighted, where is a lighthouse, flagstaff, and thirteen cocoanut palms. but no sign of life on the dazzling white beaches. Later came Fortune Island, and stopping far off shore, the one white resident came to us in a jolly boat rowed by a half dozen husky negroes, and got his mail. Although the sea was as smooth as glass, of a wonderful, indescribable blue, and the little cluster of houses in the distance, in a setting uf araceful palms with foregrommd of smowmhite beaches, was most beautiful, the heat was killing, and we were slad when the steamer left it all behind. Later the light on Cape Maisi, Cuba, Was raised, and then came the boisterous and lonely Caribhean Sea. Heary thunder storms were soon frequent, and the heat during the da! was intense. hut the nights, as the moon was full. were glorious. Finally, on the last day of May, at eleven in the morning, we sighted the rugged coast of Colonmbia. sharlowed by masses of deep clond, and not long after we were in Colon.

Uthougli soon transferted to the train that crosses the Isthmus, we had a cliance to see the building where twenty-four [nited States 
marines stood off four humdred Colombian regulars: to take in the negro huts that cluster about the town in every swampy spot; and to size up the small, scraggy horses, the parrots, monkeys, and a good percentage of Colon's two thousand inhabitants.

The afternoon train scheduled to leave at 2.45 gets away promptly at 3.30. Almost at once the jonrney is made interesting by the relics of the French canal diggers, and such relies! Trains of abandoned cars, overgrown with vines, trees, and lusty weeds: mountains of corroding iron pipe, hunclreds of tons of rusty rails, clonkey engines, locomotives, dredges-all crumbling, rotting, sinking out of sight in the

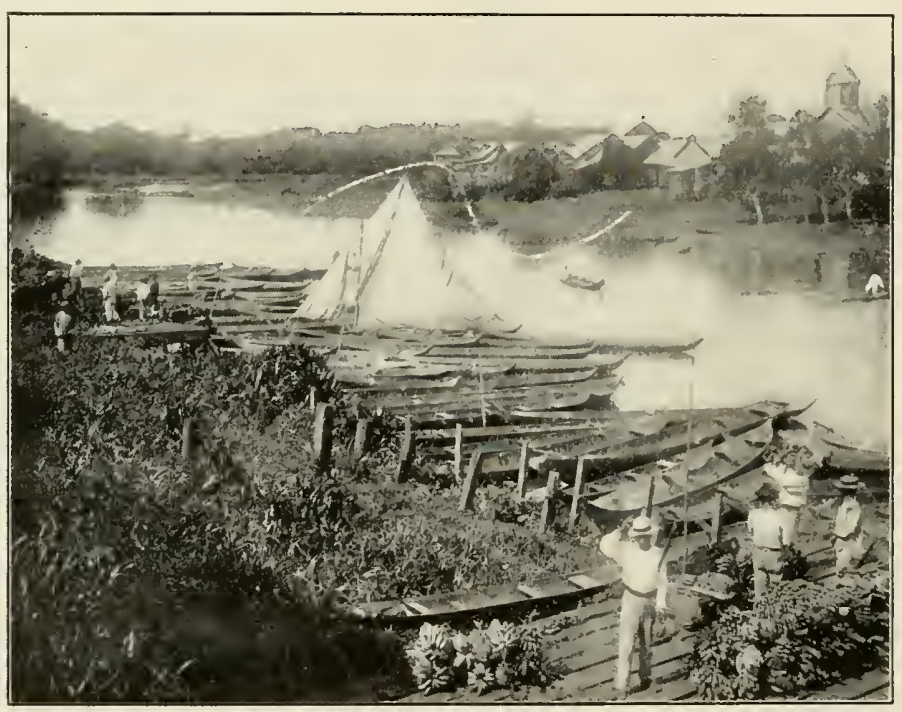

IN THE CANAI, ZONE-RIVER VIEW.

slime, or covered by the rank swamp growths. Further on were linge warehonses, said to be full of expensive machinery, and then the chateans of the French engineers, once trig and neat. now tawdry, desolate, deserted. We saw the Chagres River, and very harmless and muddy it looked; observed Monkey Hill ceinetery, and wondered why the French engineers elected to live in a swamp and be buriesl on a hill; ardmired the fine work clone in excavating the (ulebra cut; tomk note of the types of jungle wrowth, and at six in the evening arriver at the city of Panama. We were met by the seont, and at once taken to the Hotel Grand Central. 
Here was a leatly, sticky, oppressive heat, with not a breath of air stirring. The bare bethoms were like orens, and eren the come of mossuito netting that hung over the bed was to the imagrinaton at stilling as a blanket. It was to hot to think of sleep. so we wanderent about the city: interested, amused, and disgusterl-interesterl by the quaint and ancient architecture, anused by the police enstom of blowing whistles in concert when the chocks struck the hour, and disgusterl by the smells that many side streets developed.

The next morning after coffee we went lown to the water front, where, lying high and dry on the beach, as the tide was ont, was the Hmirente, the sixty-ton schooner that was to take us to our ilestination. The crew of five negroes, headed ly the mate. was slowly getting our outfit aboard, and at the same time chaffing the crews of nearby hog schooners that were unloading by pushing their sfunealing freight into the water to swim ashore as best it could.

From here we went to Don l'ablo's offices to discuss foorl, merlicines, hanmocls, ammunition, clothing, etc., until it was time for noon breakfast and the regulation sicsta. Just a word abunt Don l'allo. ()ne of the wealthy and progressive merchants of the new repullic, he not only treated us with every consideration, and purchased most of our supplics, but it was due to his alert helpfulness that we were not tied up in that torricl city for a week or more, instead of getting away in three days. but to return to our story. The breakfast was not a suceess from an epicurean stanclpoint, nor was the sicstu. for it was too lunt to sleep. So, assembling in the foyer, we watched the drown darkeys on the curbs opposite, and waiterl for the midclay leat to pass. After a time I was courageous enough to look at the themometer and it registered ninety-seven degrees Fahrenheit, the air fairly reeking with humiclity. Along in the aftemoon I wrote some letters. but conlel get no stamps, as the government had interdicted their sale at hotels. because the tourists had been in the habit of buying them for curios. instead of attaching them to letters as they should: at least that is what the clerk said.

Finally, on the aftemonn of the third day in Panama, all was reacly. The Almirante lay about a mile from shore. There is a twenty-font ticle, so it is said, and the row to the schnoner gave us a view of many cattle and hog hoats, and a good idea of the water front of the quaint city that stands at the Pacific entrance of the canal. I have saicl that the crew consisted of five, but neglected to mentin the crew cons. Jungo, and also our own. Raphatel. I hasl also forgotten the dozen live 
hens that were tied two and two, and wandered over the deck at will, as well as Domingo, the leanest, dirtiest, tiniest tramp kitten that any country ever saw.

Don Pablo and Don Ramon, another friend, came out and saw us off, and by seven o clock we were sailing out of the harbor, headed for Tuboga Island, for ballast and fresh water. All trace of the deadly heat ashore was gone, and the effects, a slight fever that all experienced, quickly disappeared. When darkness came. we slept on deck under the stars, wrapped in blankets, and awoke in the morning to find the boat at anchor just off the little town of Toboga. It was raining gently, lut

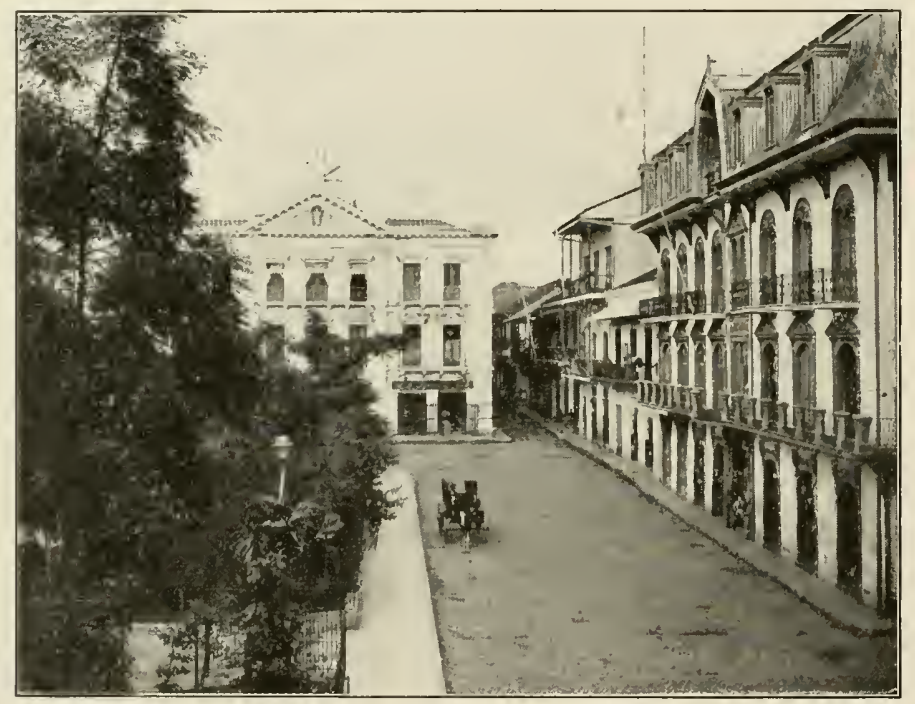

C.ATHEURAL SQI.IKE IND HOTEI, GRAND CENTR.IL, PANAMA CITY.

no one cared, and after coffee we went ashore to buy eggs, pineapples. and lananas, and incidentally to get a shore breakfast. This was served in a neat room by pretty. Indian girls, and was the best meal we had eaten for a week.

The town has about one hundred dwellings of bamboo, plastered with cow dung, and a small church. It is nestled at the foot of a high riclge. cultivated almost to the top, while about the houses cluster cocoanut palms, pawpaw and chicle trees. It is a very healthy place, as the water is good and there are no mosquitoes. Late in the afternoon we cot away, Jut as the wind was light, we did little but drift. Then it 


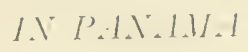

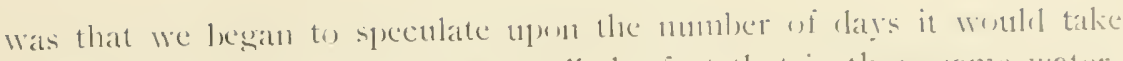
(1) reach one destination. and to recall the fact that in these same waters Cortez once lay becalmerl for seventy days, and at this season of the year, too.

The next morning we were still in sight of Poboga, and spent much of the day in rifle and revolver practice, the sulls on hits of driftweres making excellent targets. There was also the chance to size up lis Cupitan, a nervons, wiry, native L'anananian, and to discoser the very primitive icleas of cleanliness that our couk was possesserl of. For example, his plan for cleansing the tin coffec eups was to pour one

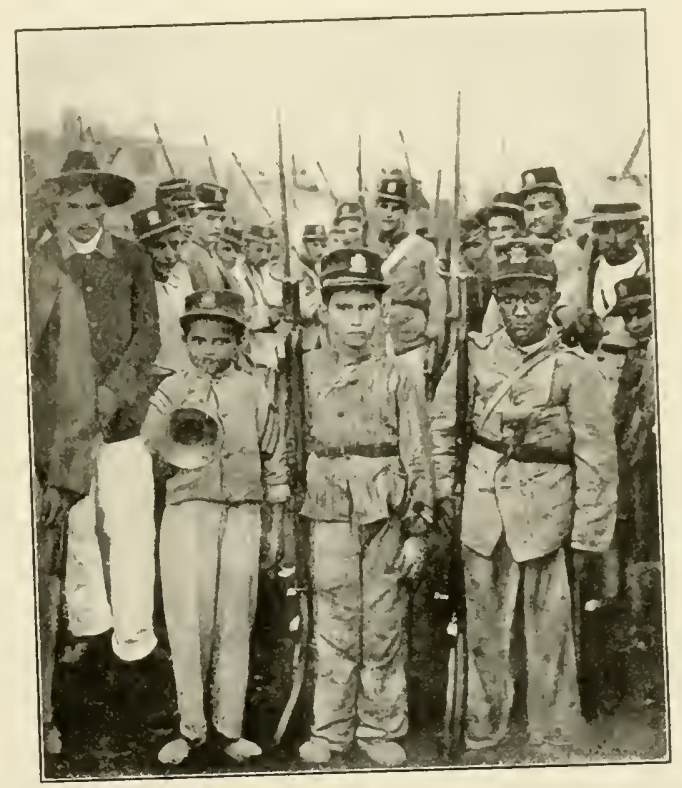

PART OF THE PANAMANIAN ARMY.

half full of water. rinse it around, pour the same water into another. and so on until all were thus washed. He also had a barrel of "biltong" or pickled beef for the crew, that was washed each day and hung on a line to dry. It certainly was strong meat, and the smell of it aft came near making us all regetarians. Slowly the boat drew on, the passengers killing time as best they could, till funally. Punta Nalo came in sight. It was at this time that our first use for the medicine chest occurred. The Commorlore rolled his sleeves high to the tropical sum, and in a few hours had a pair of the redkest, sorest arms that were ever seen. They 
gave out heat like base burners, and ached if one pointed at them, so they were anointed with cooling salves, hung in slings, and nearly cured by the time he got ashore.

Thus we sailed and drifted, chiefly the latter, sleeping on deck until driven into the little cabin by an unusually heavy shower, usually to be driven out again by the heat, the bilge smell, and the ants, of which latter we had our own private colony. After a tine, we left Panama Bay and felt the long swell of the Pacific. Then was sighted Punta Noro Puercos (Cape The-Death-of-the-Pig), and after that came a coast-rugged, mountainous, with no harbors, and the mountains shadowed by dense clouds, with all the evidences of continuous and heary tropical rainstorms.

After more drifting came I'unta Mariato, which we rounded, and turning due north, made for the Gulf of Montijo, where the schooner was to lie while the exploring party was ashore. Even after rounding the cape, the wind still continued light, and progress cane chiefly from the impulse of the Pacific swell.

In these waters were many sharks, two of which carry a half dozen bullets apiece that I pumped into them from a Remington repeater, early one morning. Then, too, there was a water snake, Culcbra marina, about three feet long, that was often in evidence, sometimes as many as thirty being seen in a day. We fished constantly, getting no bites, but the crew were more fortunate and speared some fish of a kind new to me. One, long and slim, resembling a mackerel, was of a beautiful bronze tint, with a spike on its nose, and a back fin running from the gills to the tail. Another was short, chunky, of a dingy blue color spotted with white polka dots. The natives called the former the "durado." but had no name for the latter.

Our drifting by the point did not last long, as the weather suddenly changed and the wind became so squally that the captain put out to sea lest he pile his vessel upon the inhospitable shore. That night I tried to sleep in the cabin lut it was too disagreeable, so I put on a light rubber coat and rubber boots and slept soundly on deck with the rain beating in my face. It was so scorching lot in the daytime, that, when drifting, a tarpaulin was rigged as a shield under which were swung the hammocks, making quarters that were fairly comfortable. Some one called it the "Touraine," because when it was half dome it began to rain.

Soon the schooner was off the Quebro, a part of the territory said to contain a large settlement of outlaws. These fugitives from justice had heard of the approach of the Americanos and were rumored to be 
prepared to resist any examination of that part of the land. If they l.elieved the stories told them by the Indians, that they were to be enslaver and bave numbers branded upon their foreheads, one can scarcely blame them.

The oljective point, however. was farther down the coast, so we" only saw the mouth of the Queloro River, with frowning momtains for a backgromul. Very glad we were that the Quebro was not then in our itinerary, for that part of the comtry was black with thumeler clonds, and drenched with showers that bore a close resemblence to cloudbursts.

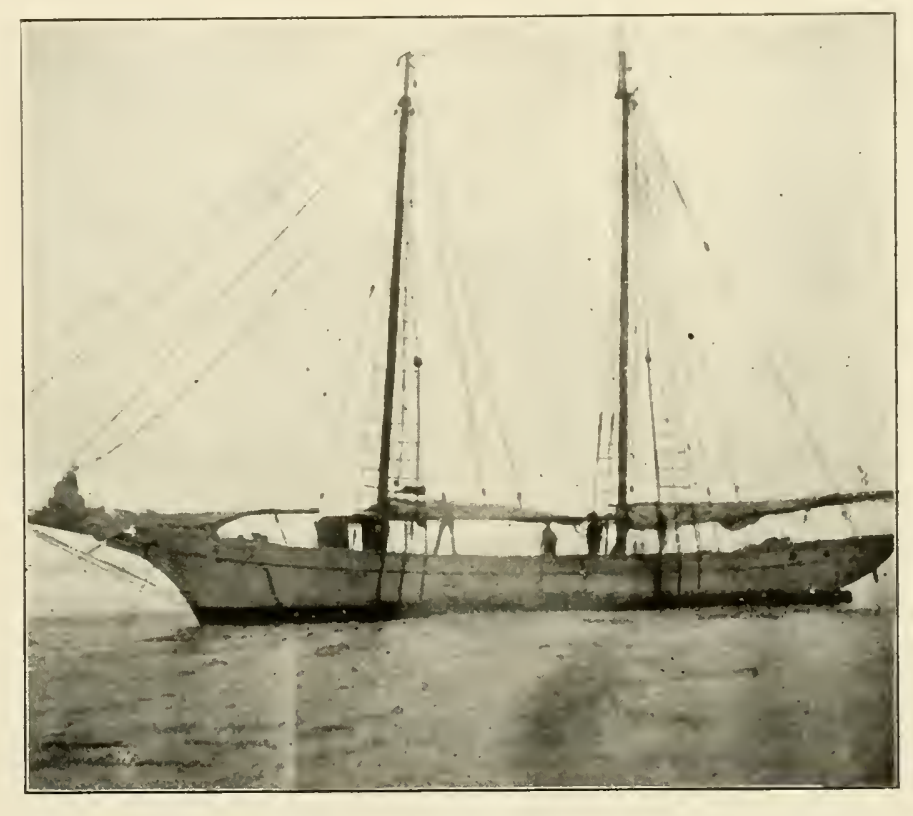

THE SCHOONER "ALMIRANTE."

Coasting along still further. we descried the mouth of the Mariato Rincr, where the first landing was to be made. Here a fresh difficulty arose. El Capitan feared the shore and wonld not go nearer than five miles without a pilot. After a lurid conference, in Spanish. Portuguese. and English, it was suggested that he circle the nearby island of Cebaco, stop at Gubernador Island and borrow a pilot. And so it was decided. and the start made just as night fell.

That night the air was heary with moisture and had in it all of the makings of an electrical storm of great violence, but asicle from the 
St. Elmo's fire that appeared at the masthead, nothing happened. The crew was much exercised abont these strange balls of light-it was Malo with a capital $M$ to all of thenn. No such superstition affecter our party, however, and when the morning cante we laughed away their fears, and as the day advancerl they grew ashamed of the terrors of the night. By noon the schooner was off Cebaco, which ends in a jagged reef where rough water is to be found. As the wind was light and the current strong. the flmirante was carried quite close to this danger point, although both jibs and the fore and mainsail were clrawing full. the latter two being wing and wing. Just as we passed the reef, with no warning at all. came a squall that was as near as possible to encling the cruise in disaster. The flmirante heeled over until her rail was tnder, and plunged forward like a race horse. El Capitan, at the tiller ropes, screeched shrill orders, and the crew worked like demons to get the flying $\mathrm{jib}$ and the foresail down. In the face of that wind it was no mean joh, as the sail was as rigid as iron, and it was not until a sailor climbed the mast and pulled the hoops down, a few inches at a time, that it was lowered. Even then it could not be tied up, but bellied far out into the water. The same difficulty was experienced in reefing the mainsail. Iint finally, after much labor, the schooner was in hand and driving ont to sea nnder jib and reefed mainsail. Is the squall had now turned into a hurricane that drove the wam spray from the wave tops into one"s face like hail, it looked as if we were likely to be driven far out of our course. El Capitan therefore decided to try to come about and rum between Cebaco and Cubernador for shelter. Three times he tried and each time missed. Then he prepared to jibe. The Americanos, however. would not have it, urging that either the rigging would part or the masts be carried away by such a measure, and he finally gave it up. Then he tried to come about again, and by lowering the jib for a monent, and raising it again, was successful; the old tub came about and headed for the haven. Then followed three hours of as rough sailing as I ever expect to see. There was no particular danger, if everything held, but the seas that pounded the side and often came aboard were lig and angry, and the wind fairly shrieked. Nothing happened except the parting of a stay, and the partial collapse of the cook's galley, and by nightfall anchor was clropped close under the shelter of Gubernador. in still water, and the weary voyagers went to sleep to the roaring of the breakers on the other side of the island.

Going ashore in the morning. we found that the island was owned by onr friend, Don Pablo, and it was here that his pearl fishing schooners 
refitted. The few inhabitants were lndian, and in lexks, habits, anel manner of living, just what one finds from Xexice all the way down to the Smazon. They were friendly and browght us pincapples that were most delicions, and after much palarere we secured a pilot. It was while Walking aleng the shore from one little settlement to another that the somt, with whom l was, had an unpleasant experience. Ife were mucke a tree that losked for all the worlel in lark and leaf like at pear tree. with a fruit that had the appearance of a small apple. We each picked half a dozen and the seout bit intos one, remarking that it tasted

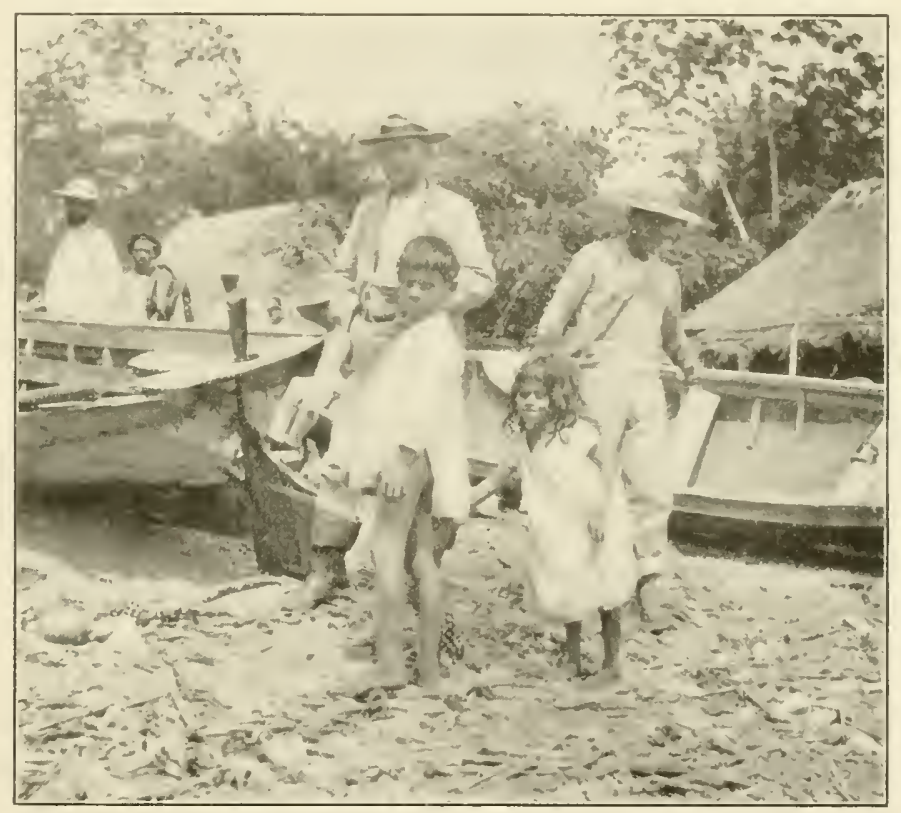

ON THE BEACH, GUBERNADOR ISLAND.

like a sweet apple. I used mine, however, to pelt the native dogs that were following. and then both forgot the cpisode. After the return to the schooner, however, while getting under way, the scout was taken suddenly ill, romiting, retching, and complaining that he felt as if he were on fire inside. We gave him such simple remedies as were obtainable, but it was hours before the attack passel off. The natives sail later that both tree and fruit, known as the bitter mansana, or arsenic apple, are intensely poisonons. A horse 
tied under the tree for a few hours becomes very ill and loses his hair, while it is sure death for a man to eat one of the apples.

With the pilot aboard, we soon gained the gulf again, and ere long were off the Palo Seco (the withered tree), where, if luck favored, guides and mules were awaiting us. This time our captain ventured within three miles of the shore and sure enough saw two men. A boat was sent, and in conrse of time, night having fallen, a light appeared dancing over the waves, and soon there stepped aboard the Pioneer, who

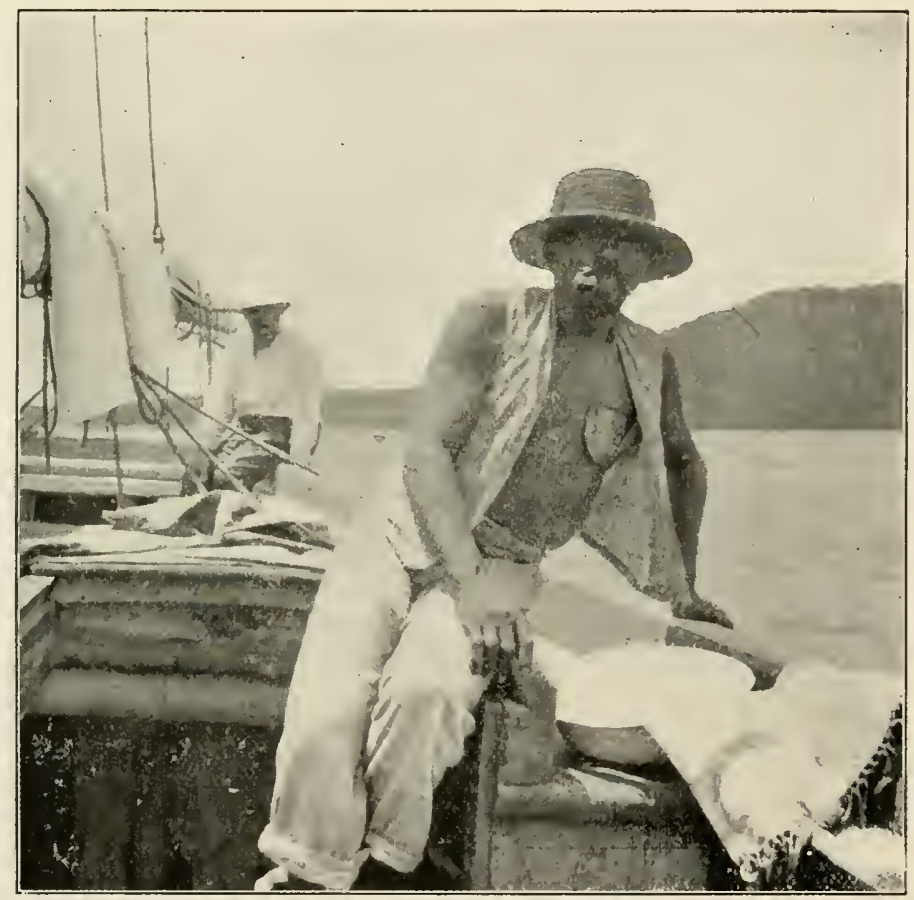

JLN(O), COOK ON THE "ALMIRANTE."

was to furnish guides and transports. He had been waiting nearly a week, and would have left the next day, believing that we had turned back or been wrecked by one of the Pacific hurricanes.

The Pioneer had been in that country for many years and his stories of rubber gathering up in the Canca, and adventures in the Darien with the fierce San Blas Indians, were most interesting. As is well known, these savages do not allow trespassers mpon their lands, althongh they do not molest those who gather rubber in the wilds adljacent to 
their domain. The Pioneer acknowledged that once le broke an agreement with a chief, stole across the river that markerl his boundary, and began work on the rich forbidelen forest. As a result, his men were shot down. one by one, until only he and one negro escaperl.

Another time he was caught far wp a river, by the dry season, and had to wait for the rains. When they finally canne and he gon his rubler afloat, they hat for provision only rice and lananas. Floating down the river one evening in the bright moonlight, they canc to a fine stretch

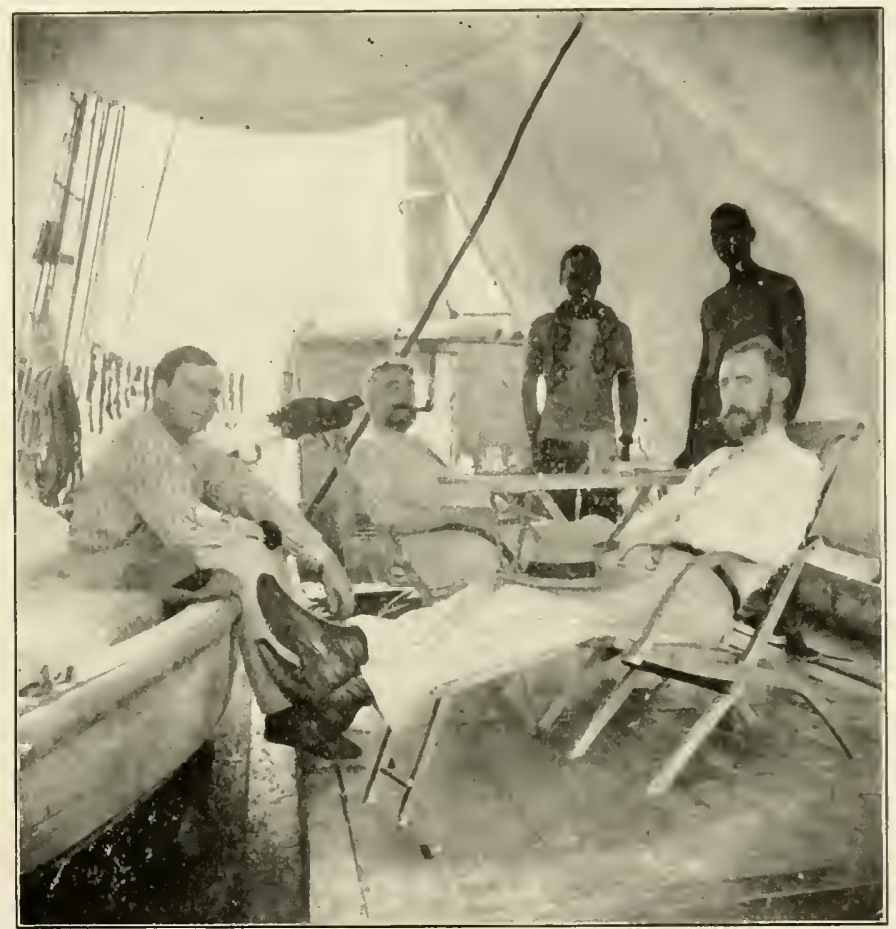

THE TOERAINE-C.NNSAS SHELTER ON THE "ALMIR.INTF."

of beach, and he at once ordered the canoe men to make camp there. They refused with every evidence of extreme terror. as they said the place was hannted. The Pioneer, tired and hungry, forced them to do as he ordered, by threatening them with his revolver. He soon had supper and was quickly sound asleep under his mosquito netting. Abont midnight, just as the moon was setting, he was awakened by a strange and dreadful cry. Sitting up to call the crew, they suddenly threw themselves upon him. held him down, and practically gagging him kept 
him quiet until the screams ceased. Then they whispered that it was death to speak aloud and returned to their slceping places. The next moning they explained that the screams came from the spirit of a man who was murdered and buried with money on him, and if any one had spoken the spirit would have at once attacked and killed the speaker. No whit impressed, the Pioneer searched the river bank, and finally found a huge and ancient sloth, which he promptly killed. And thus was the mlneasy spirit laid, for the cries ceased from that time.

The rubber trees up there, so he saicl. were from two to three feet in cliameter, and most abundant bleeders. They always cut them down to secure the rubber, as they get more that way and know that if they spared them the next crew of gatherers wonld destroy them. He said that on the land we harl come to examine, the rubber gatherers had been in the habit of cutting the trees clown, hut that two years before the practice had been stopped, and a premium of twenty-five dollars paid to any one who informed of such destruction. As the whole tract. some five humdred thousand acres, was private property, and wild, and as most of the Indians lived on the other side of the mountains, the rubber was quite plentiful, and with a very little system, the crop could be greatly augmented.

The next day was undertaken in good earnest the work of gettng our stores and ourselves safely ashore. And no light task we found it. The surf was tremendous and it was impossible, even with the skillful managenent, to get to land without being drenched, the men being landed in the ship's boat, the stores coming ashore in a dlugout.

While the goods were being landed, the Scout and the Prospector stripped and took a bath. Later they shuddered when they remembered it, for the sharks that haunt that shore, coming far into the shallow water, are hig and voracious. In the meantime I was looking at the forest. Much to my delight I found Castillon trees arowing within one hundred feet of the shore. Small ones to be sure, hut thrifty. One, about three inches in diameter, had been tapped, and from the cuts I stripped some good strong rubber. 


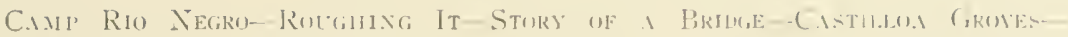

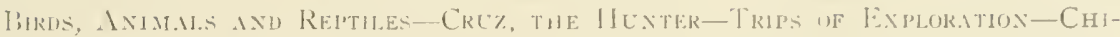

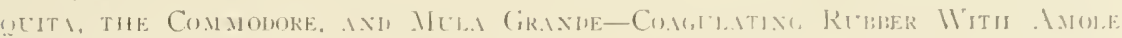

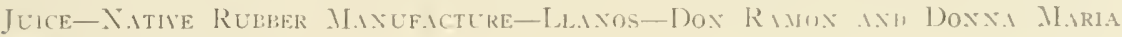
- I TREASTRE HUNT.

$\mathrm{O}$ TR plan at first, on coming aslore on the Izuero l'cninsula, liat heen to campl right where we landerl, but the "heng-hengs" (rodadors) were so troublesome that another spot had loeen chosen, some eight miles inlanel, and having turned our belongings wer to the mosos, we started on the trail for camp Rin Negro. The Commodore led. because he had brought lis shotgun and planned to shont something for supper. He made a gallant figure, striding along the trail in rubber soled shoes, and had deer or turkey appeared. they certainly would have dropped. Fut the ganc was wary, and the only creature that dropped was the hunter himself. when he inadrertently trod on a slimy log and sat down in a pool of water.

The trip took about three hon's and led slightly nphill all of the way. The trail was fair, and ran through a sort of open forest. where there were many huge trees, but not much of the dense jungle that is so often to be found in the tropics. The soil was a gravelly loam, with a clay underlay. and seemerl to he rich, while the berls of the brooks and creeks were of lard gravel and boulders. All alons the trail were Castilloas, sometimes singly, and often in clumps. None of them were over twelve inches in diameter, and most of then had been tapper. Now and then was one that had been felled a year or two hefore, and frequently we saw stumps of what must once have heen fine, large rubber trees.

Eight miles is a long distance in the tropics. and thongh lightly clarl and walking slowly. we were soon very warm, and wet through with perspiration. The Pioneer ventured the prediction that this was the last long tramp upon which the Commolore would carry an eightpound gun, and his prophecy came true. Even long journeys end. howerer, and after forling the Palo Seco, and a little later, the Negro River, we encerged into a fine grove of Castillods, and fronting it, a palm thatched house that was to he our lase of operations for many days. An hour later the mules arriver with the narg bags, and within fifteen 
minutes we were in dry clothing, had hammocks slung, and were ravenously watching the cook prepare supper of jerked venison, bacon, dago bread, and coffee. Later he made delicions chocolate, using condensed milk, and serving it in calabashes. Just here-the supper and its preparation suggests it-let me say that the little camping stove was all right, but three stones between which the fire was built were just as good, while a candle box made a fine molding board. So, too, with the hip boots of rubber-they kept us dry a couple of times in fording creeks, but it was so much easier to slop right through and dry out on

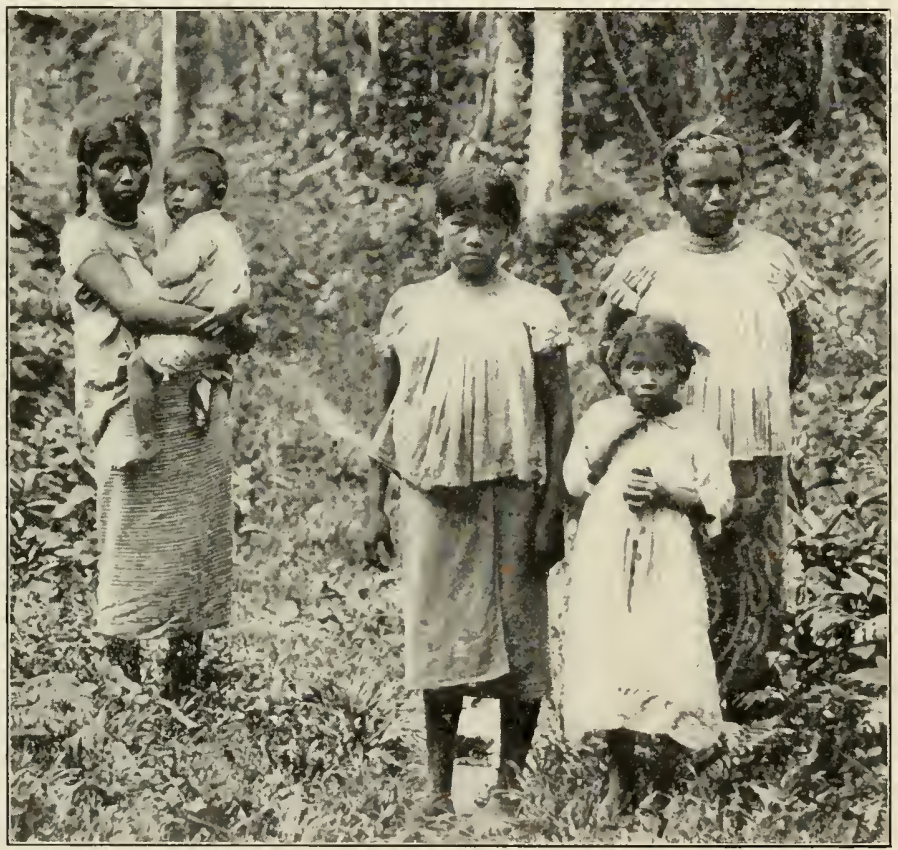

PANAMANIANS.

the march that we didn"t bother with them after the first day or two. It was lucky, however, that there were ample stores of rice and salt, for the natives had neglected to clear and plant during the dry season just preceding our visit, and the whole countryside was on the verge of starvation. Not that they worried about it particularly: they simply ate what they could set, and contentedly waited for the next dry season to come around.

Our first night in camp part of us slept in hammocks and part on 
a platform of poles, nunder which the mosos crept when the evening rain eame on. The l'ioneer lept a lantern burning. as he said it scated atway the vampire bats. It diel not frighten the insects. howerer, for the merning light slowerl four white men well speckled with red spots. Just What the insect was conld not be discovered, but it was most industrions. I counted fifty-seren well defined lites between knee and ankle, and there were others. I also discovered how to scrateh these lites and suffer no ill effects. and (oh! the joy of such scratching! The rennerly was a five per cent. solution of formine applied to the surface after an orgy of seratching. In two hours after the application, all the prosisu either from bite or finger nails wholly disappeared. It being Sumclay, our

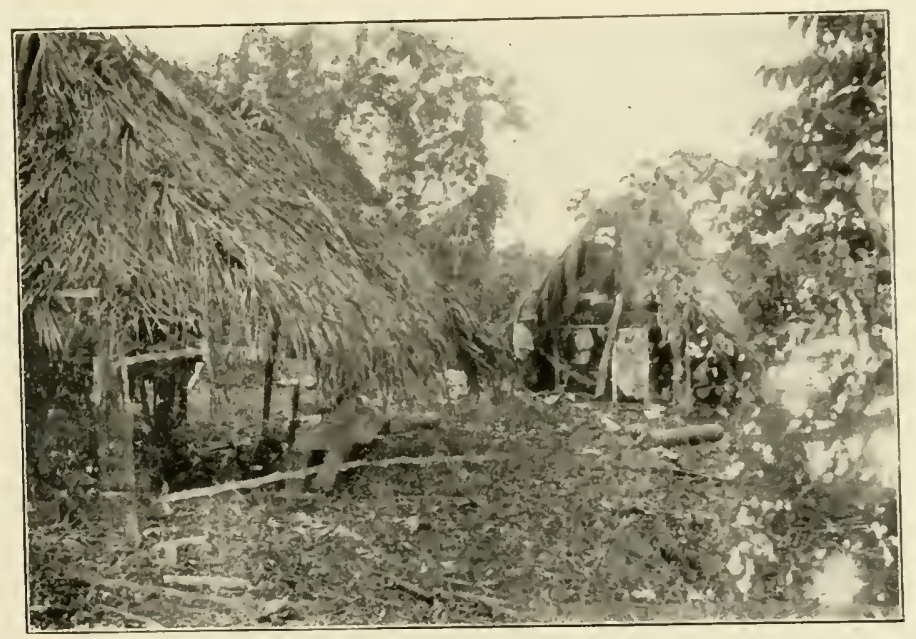

CAMP RIO NEGRO.

mozos piously refrained from work, but in spite of their scruples, they were induced to build a shelter for themselves, which they finally dicl. getting the roof on just before the afternoon downponr of rain.

In speaking of the lack of enterprise that the natives show. it must not for a moment be imagined that they are hehind the times in everything. In the utilization of public money, for example. they could give Tammany Hall points of value. To cite an instance: The hone gov. ermment at Panama City appropriated three thousand dollars for the building of a bridge over a river that Howed near a certain town. Shortly after that one of the holders of the fund approached the Pincer and asked for an estimate as to the cost of putting up the bridge, renark- 
i:- ge that he harl two thonsand dollars for it. The Pioneer offered to (lo it for that sum. but the next morning. when the papers were to be drawn, there renained only fifteen hundred dollars. Then the trustee proposed that a seven hundred and fifty dollar bridge be built, and that he and the J'ioneer divide seven hundred and fifty dollars. It took some trading to arrange that, and before it was finished there was left but six hundred clollars. Then apparently all of the officials got a slice. for two days later there was but ten dollars left. Nor has the brielge ever been built, but there is still an exeellent ford. which appears to suit the people just as well. Thus it will be seen that they expul us in the distribution of gorernment appropriations, and outclass us in some forms of piety. ()ne of our rublser cutters, for example, bore the name of Jesus Maria Dios-but he did not look the part.

During the forenoon I looked over the srove of Castilloas that fronted the house, and found that most of them had been tapped that season. Indted, one of on mosos said that they had been tapperl twice. The process of tapping here is quite different from that picturecl by most who tell of the gathering of Panama rubber. They usually describe a series of zigzag cuts, rumning one into another from the base of the tree far up the trunk. Here each cut was individual, and made with two strokes, one horizontal, and the other slightly downward and joining the first so that a small slice of lark was taken ont. In the lower part of the cut the thick later gathers and is scraped into a calubash with the fingers. The trees, as a rule, were tapped as high as the native could reach, and frequently a rustic ladder or a rough staging enabled the watherers to get higher up on the tree.

It seems that the plot of trees at Rio Negro were not self sown, but were planted by the Indian in his rice field after the crop was gathered. There were one hundred and five trees on abont an eighth of an acre of land, said to be fonr years old. The rest of the clearing had grown up to jungle, but where the rubber trees were it was quite clear and the trees big and lusty. Their conclition made me wonder if the cleaning that is carried on by wp-to-date planters is after all so much of a necessity as they believe.

Althongl it was Sunday, all went in swimming in the swift Rin Vegro, and all also went fishing (with a stick of (lynamite) but only sut one. The swimning was not prolongerl, however. because of the rudadors, that were quite tromblesome. While in the water a hand of brown faced monkeys expressed their disapproxal of our Sabbath breaking loy throwing sticks and branches at $11 \mathrm{~s}$ from the tops of the lofty 


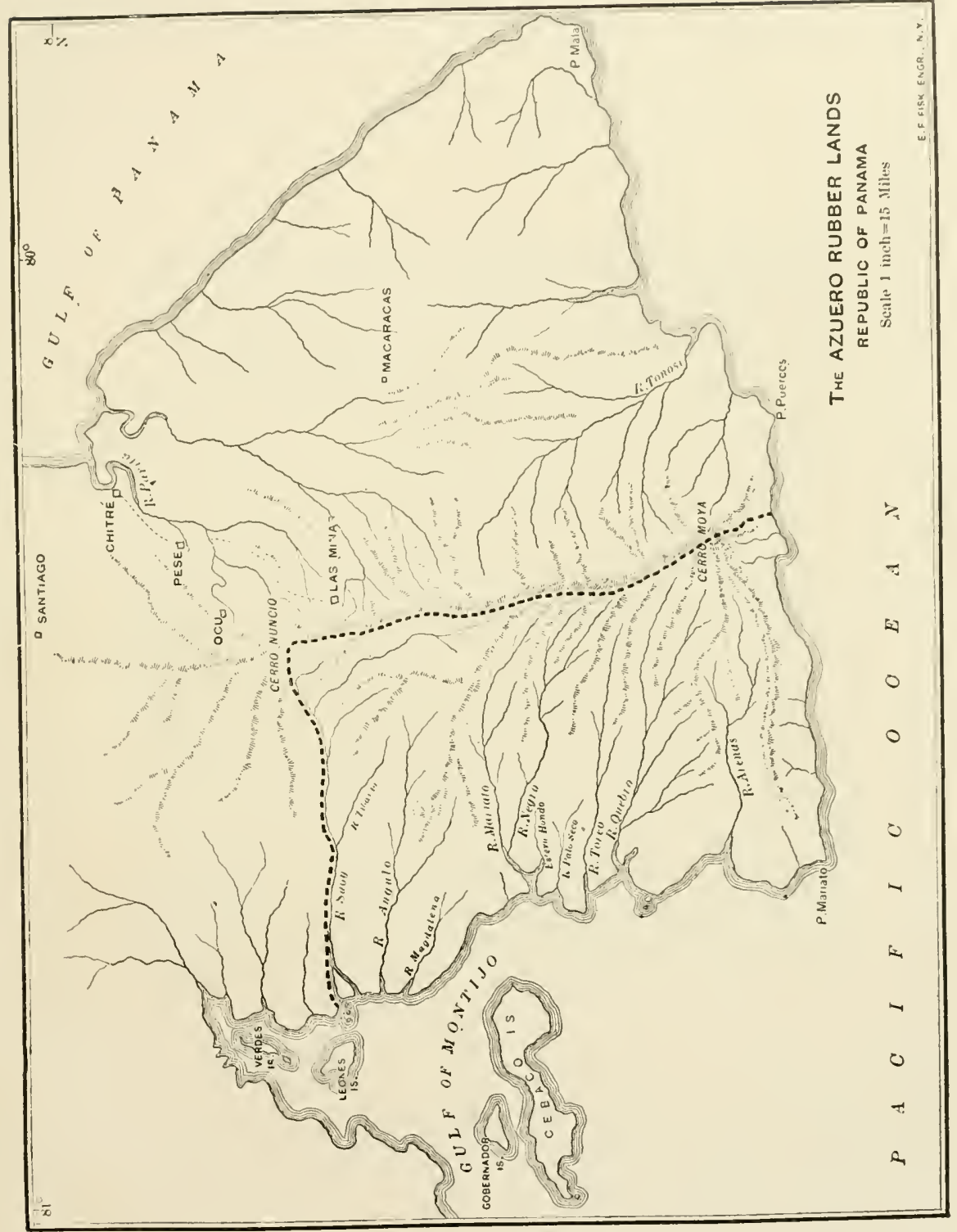


trees that hung far over the water. Speaking of the animals, there were deer, wild pigs, tapir, tiger cats, and jaguars, but they were rarely seen. Evidences of them were plenty. however. Once when we visited the llanos (grass plains), we saw where a jaguar had killed a two-yearold colt. For birds, there were innumerable humming birds, a great variety of song birds, hawks, parrots, buzzards, cranes, grouse, doves, two kinds of wild turkeys, and the justly named "fire eracker bird." We saw no snakes, but iguanas and lizards were common.

The Indians think every kind of snake, and even lizards and tree frogs, poisonous. They have, however, what they assert is a sure cure for the bites of poisonous reptiles. After being bitten, if the sufferer will shut his eyes, reach behind, and select three leaves (any kind will (o). quickly rub them together, and apply to the bitten part. a cure always results.

()ur helpers were in part Indians, descendants of the Aztecs, and in part negroes from the Canca. ()f the former was Indolencia, whose strange, complaining "monkey call" could be heard for miles. He always kept it up when alone in the woods, even if only a few hundred yards from camp. Of the latter was Cruz, a tall, loose jointed darkey, freshly pitted by smallpox. He was the hunter, and was equipped with a muzzle loading "gaspipe" gun with a percussion lock. It was worth going miles to see him flush a turkey, locate the tree in which it alighted. steal within range, and then snap cap after cap, until finally the gun went off and the turliey dropped, oftentimes getting away even then.

As it wonld be impossible to examine carefully the whole of the eight hundred square miles in the month allotted to it, we first got the general lay of the land, then laid out trips through typical sections. estimated their areas, and computed the number of trees. From Rio Negro camp (about two hundred and fifty feet above sea level) trails were cut north, south, east, and west. Then came long, hard tramps. counting and measuring trees in typical blocks, and much questioning of native rubber cutters for a fair estimate of the conditions that obtained elsewhere. One fact soon impressed itself upon me. The Castilloa was certainly better adlapted to flonrish there than any other of the native trees. In spite of the war of extermination that had been previously waged against it, it was more abundant than any other single tree. It often happened that a group of from forty to fifty could be counted from the trail, and it was a rare experience to go twenty-five feet in the lower forest without seeing at least one tree. While many of them were lofty. few were more than eight or ten inches in diancter. The very largest 
tree that 1 saw, far up in a secheled mountain valley, was not over twenty-two inches in diancter. The natives conld always pick those that are the best milkers. As a rule, these trees had a larger leaf area than the others, which accounts, I think, for the extra flow of later. Those in the dense forest seemed to bear few seerls, while on the erlges of the trails or in open places they were abundant seed bearers. There seemerl to be no leaf or bark diseases. and even trees that harl been mutilater the worst by the rubluer gatherers seemed to be somd and healthy.

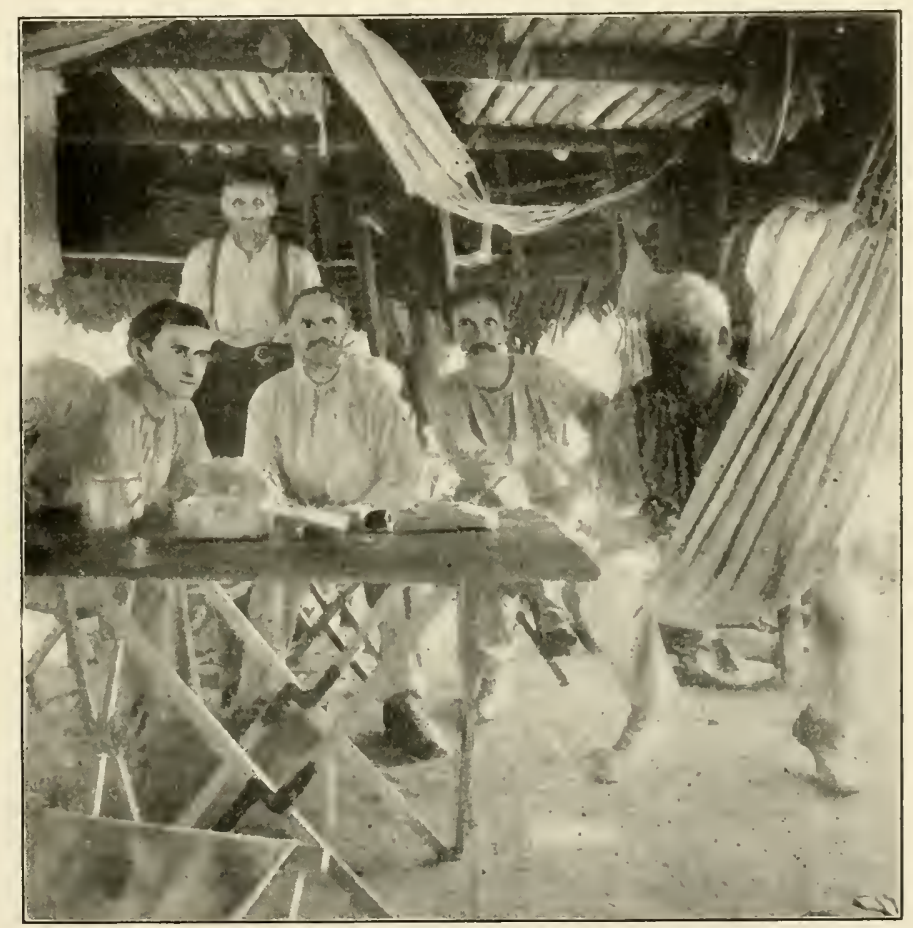

INTERIOR OF CAMP RIO NEGRO.

Exploration was, of course, greatly hindered by the heary rains that came nearly every afternoon, and sometimes in the moming as well. These swelled the rivers so that fording was difficult, and turned the steeper trails into muddy torrents. The shacks of Indians who were collecting rubber were often visited, and deserted camps always examined. A canip usually consisted of a palm thatched leanto, just hig enough for two men to sleep in, on a narrow pole-covered bench. 
In one corner was a hole in the ground about two feet deep and eighteen inches in diameter, to receive the rubber milk, and in which it was later coagulated. Three stones as big as a man's head formed the fireplace. with a bunch of dry sticks for fuel; calabashes for gathering, the machete for tapping, and the amole vine for coagulating. finish the tale of the rubber gatherers' equijment.

Although camp Rio Negro was headquarters, we were often obliged to make other camps for a few days. For example, when examining the upper valleys one thousand feet above sea level, a rulber gatherer's shack was our home for three days. Two things in particular were noted on this trip. The rubber tree rarely grew on the tops of the "hog backs" or ridges, but on the sides, and in the valleys. Nor did it grow in wet lands at all. Then the seeding of the tree at that altitude was about a month later than on lands from fifty to three hundred feet above the sea.

There was much less game in the upper country, and, weary of timned meats, it was not surprising that we tried and enjoyed parrot stew, or that the monkeys should have been turned into rabbit sternot big. black, twenty-five-pound monkeys, of which we shot several, but the little brown-faced edible monkeys.

It is not to be supposed that all work was done on foot. Wherever it was feasible either horses or mules were used, and by following the ancient Indian trails we were able to save ourselves much time and toil. The horses were small, gentle stallions and quite surefooted. I said gentle, and so they were toward all of human kind, but when turned out to browse there were some very pretty stallion fights, with no harm done, however. The mules were small, but strong, and made much trouble because they knew of the grass plains some miles distant, and were in the habit of stealing away at night and making for them. As the trails in some places were very steep, I chose a little mule called Chiquita, and she proved to be a treasure. She could ford a swift running river and keep her fect. while the others were stumbling and half swinming. I verily believe she could climb a greased pole or slide down a $\log$ chute and never miss her footing. if she so elected. The Scont. the Pioneer, and the Prospector rode horses, while the Commodore, who was a trifle over two hundred in weight, took the mula grande or big mule.

Speaking of the Commodore's mount. I thought he would have trouble, for that particular mule demanded the same treatment that the other mules received. I saw him watch me when I leaned forward in 
the saddle and eased Chiquita up a sharp rise by twisting my fingers in her mane. The Commodore however, hy reason of his stoutness, conld not easily do this, and so sat up. The big nule grew sullen. and finally, as we forded the Mariato, and elinherl its steep, clayey banks, he suddenly stopped half way np, shook himself and hegan to tip slowly over backwards. ()f course the Commodore slicl off over his tail, and sat in the river, and an instant later was holding the big mule

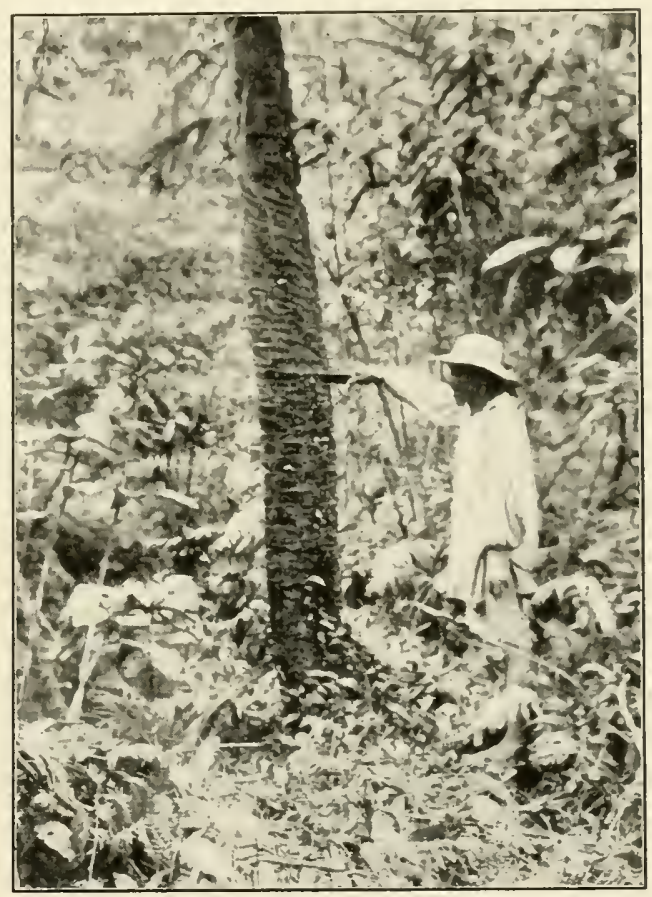

INDIAN TAPPING A CASTILLOA.

in his lap. I ought not to have laughed, nor should I, had not Chiquita turned around and winked at me.

I had long wished to see how the Indians coagulated the later of the Castilloa by the addition of the juice of the amole vine, and now had the opportunity, not once. but many times. Usually the coagulation is done in a hole in the ground; if, however, they are very careful, and are possessed of an axe, they cut a trough out of a "balsa" log and use that. When there is sufficient milk for coagulation, a buncl of vines is gathered. folded together, and pounded on a $\log$ with a heavy billet 
of wood tuntil all of the fibers are well bruised. The mass is then rinsed in water, the fluid being run through a sieve, and poured into the trough. Extreme care is taken not to stir the late.r. Instead, as it hegins at once to coagulate on the top, the rubber is gently pressed down, gathering to itself other particles, and at the same time it is forced towards one side of the receptacle. Thus by gently manipulating, squeezing, and handling, most of the coagulated rubber is finally gathered into one piece, which is lifted out and kneaded until much of the water is ont of it. Some more amole water is then poured into the remaining liquid, and by the same sort of careful manipulation another smaller slab of rubber is secured. The two are then stuck together. A week later the milk white mass of rubber will be jet black, of about half its first weight, and apparently as dry as a bone. Unless it is cut into strips and washed and dried again, and all of the anole liquor got ricl of, it will sweat and deteriorate, and have a smell that makes it most offensive.

The maclecte is used altogether for tapping by the natives in Central America. Just by way of experiment I tried two different tools that I brought with me from New York. One was a sort of farrier's knife, that did pretty well, but was not heavy enough: the other was the type of tool that is now in general use in Ceylon. While it was possible to tap with this latter tool, it did not do for the Castilloa as well as for the Herca. The strong fiber in the bark, unless the tool be as sluarp as a razor, makes the incision a tear rather than a clean cut. It is possible that the tool may be changed in shape slightly and do the work, but in its present shape it is not as good as the maclete. Speaking of the fiber in the outer bark of the Castilloa. the natives used formerly, when they found a rery large tree, to pound the bark until it was loose then cut it off and dry it, and have a beantiful snow white sleeping mat, as soft as wool, and looking for all the world as if it were the product of a loom.

Here I must mention a rubber tapping tool invented by a native Panamanian whom 1 met, and who is not only a rubber gatherer but a thinker. Although so many men have tried to evolve a satisfactory tapping device for rubber trees, it is singular that the thought of a would-be inventor in this line, almost invariably, turns first to some sort of vacuum or suction arrangement, that will not only act as a tapping tool, but pump the late out of the tree. Of course, a little stucly of the formation of the lactiferous tubes nuakes it eviclent that nothing of this sort is feasible. The suggestion, however, has come from a great 
variety of sourees, and in some cases from scientific men. Sho it was interesting to run across the same mental processes and the same sort of dednction among the natives of the rubber comntries. The illustration (page 221) shows an instrument designed and made ly the native referred to, a man named fuancho, who is shown in another illustration standing in a grove of Castilloa. The instrument consists of a cylinder of light balsa wood. wound with codline, through which runs a piston made of hard woud, one end tipped with a short iron chisel. The chisel end of the cylinder is fitted with a strip of pure rubler. a packing to be drawn tightly around the tree. The puncture made and the piston withdlaww, the hope was that the cylinder would fill with late.r. That expectation, however, was blasted, as only the usual anount of late.r followed the cut.

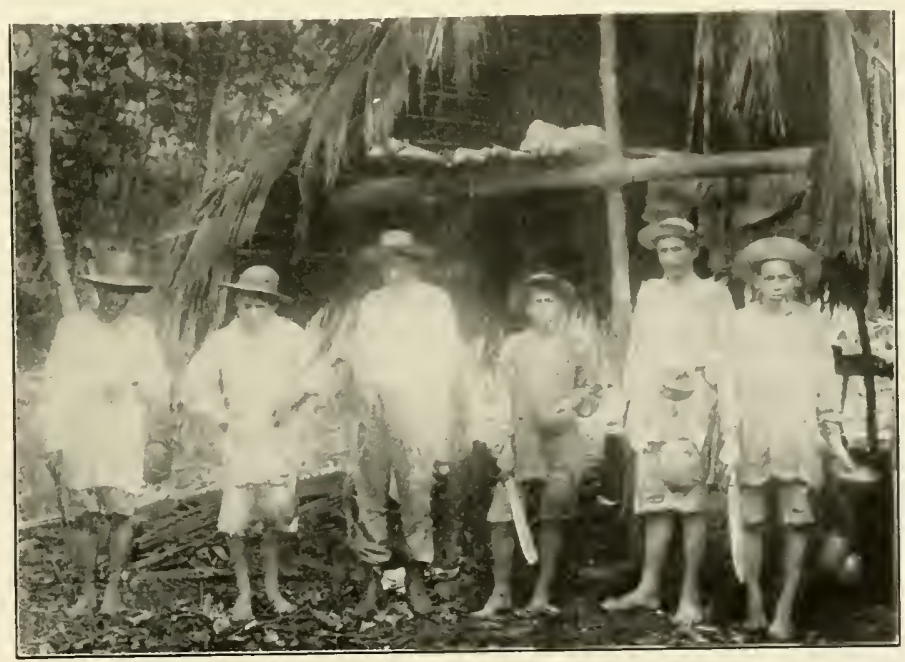

RUBBER CLTTERS IT RIO NEGKO CAMP.

Two of the long trips across country brought us out at the llanos. or grass plains-prairies containing some 25.000 acres. on which grazed some one hundred and fifty head of cattle of the old Spanish strain, but big and fat for all of that. They were not at all wild. yet to milk a cow it was necessary to muzzle her calf and tie it to her front legs, and then she seemed to feel that her offspring was getting the leclue that really flowed into a calabash. In a little oasis of trees in this prairie of rich, short grass. was a neat native house in which lived the keeper of the herd and his wife. Thin, almost to emaciation, was Don Ramon, gray haired, with the sparse beard of the true Indian. clad in white; 
he was the only energetic native that I saw on the peninsula. Donna Maria, his spouse, short, fat, and comely, in calico dress and blouse, barefooted, with a man's hat on her head, her own pipe in her mouth, surrounded by hens and dogs. cooked in a placid way that was most picturesque and restful. We slept at their house one night, but on the second visit signalled the schooner and went aboard to sleep, away from the various insects that always infest a cattle ranch.

It was during a visit to the llanos that we nearly lost the Prospector. It came about this way: From the time of the Spaniards the country has been known as a gold producer. Indeed, every brook and river showed traces of "color," while traditions of lost mines and their fabulous riches were everywhere rife. As we were not after gold, but rubber, the lost mines. or the sunken treasure slip at the mouth of the

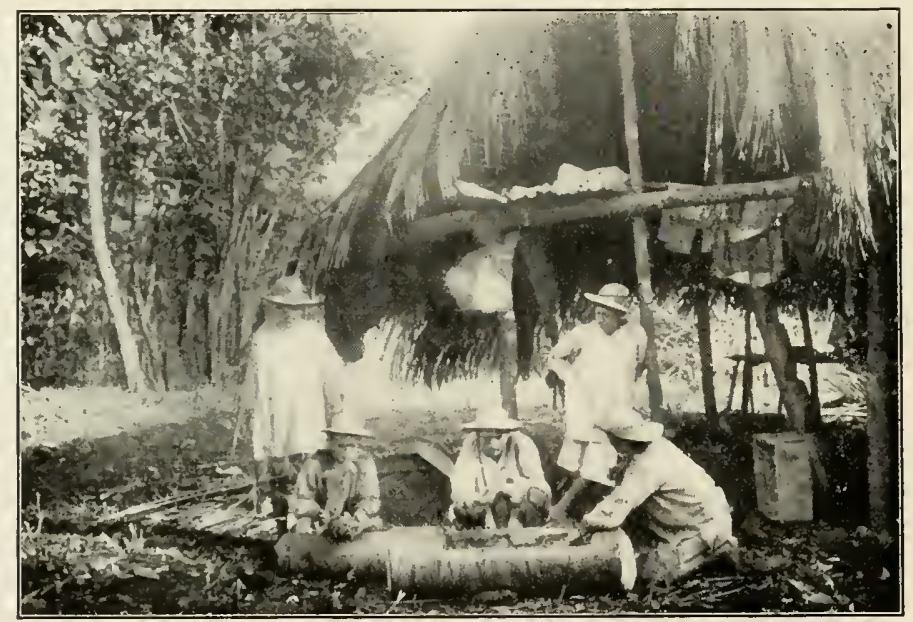

COAGLLATING RUBBER IN BALSA LOG.

Mariato, troubled us not at all. That is, not until the Niner came across the mountains, and rode into our camp with a true Western yell. He was a raw boned, good humored, shrewd Irish-American, who had been in every mining camp in North America, and who was now developing the Gallo (Golden Cock) mine. He and the Prospector got together at once and the air was full of "andesite." "quarts." and "porphory." Then they got to whispering and later parted. It was at the llanos that it all came to a head, for it was there that the Prospector began furtively to study a small diagran, and later stole away accom- 
panied by an Indian whom he hat hypnotized by the gift of a real. They took a bee line for the shore, forded the Mariato, and on a little island that is half covered ly the tide, hunted up a certain tree, strocle away so many paces by compass, and started to dig.

It was exciting to see how eagerly they plied pick and shovel. and how they started with joy when the pick struck a tree ront. And they dug and ang until they sublenly awoke to the fact that they were cut off from the main land ly the ticle. Then the Inclian went all to pieces and wept and called upon the saints. while the P'rospector uttered words unfit for publication. There was no clanger unless an alligator

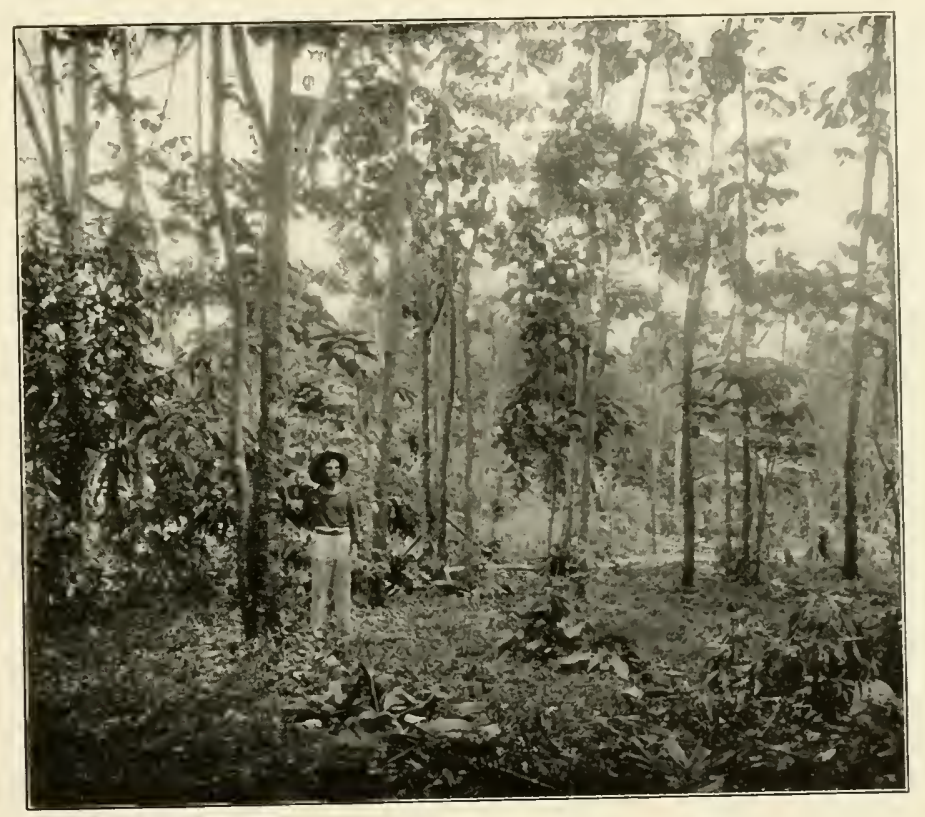

JUANCHO IN GROLE OF CASTLLOA PLANTED FY INDIANS.

or a jaguar got them, and as there was no boat the best thing would have been to wait for the ebb. Instead of that, they went further into the thicket. and a few minutes later appeared. each with a pole, and stepping into the swiftly rumning water started to cross. Very slowly: bracing themselves at every step, they waded, the water up to their breasts, and finally emerged into the shallows and were ashore. Neither of them went back, and thus ended our only treasure hunt.

The "gusano del monte," or grub fly, was quite in evidence at the llanos. I got three, the scout seven, and the rest their share-just how 
many I have forgotten. But I have not forgotten the sharp twinge, like a red hot needle, that tells of the presence of the grub in ones flesh, or the killing of it with nicotine, the heating of the spot by a firebrand, and then the desperate squeeze that shoots the inch-long intrucler out into the open.

I also learned here why it was that so many of the natives have sore feet, about half of our men being then laid off. A disease which they call the "massanora," something like chilblains, attacks them, the cause being a minute insect that is found in stagnant water or decaying vegetation. Unless cared for, the feet swell dreadfully and the skin cracks and festers, making most troublesome sores.

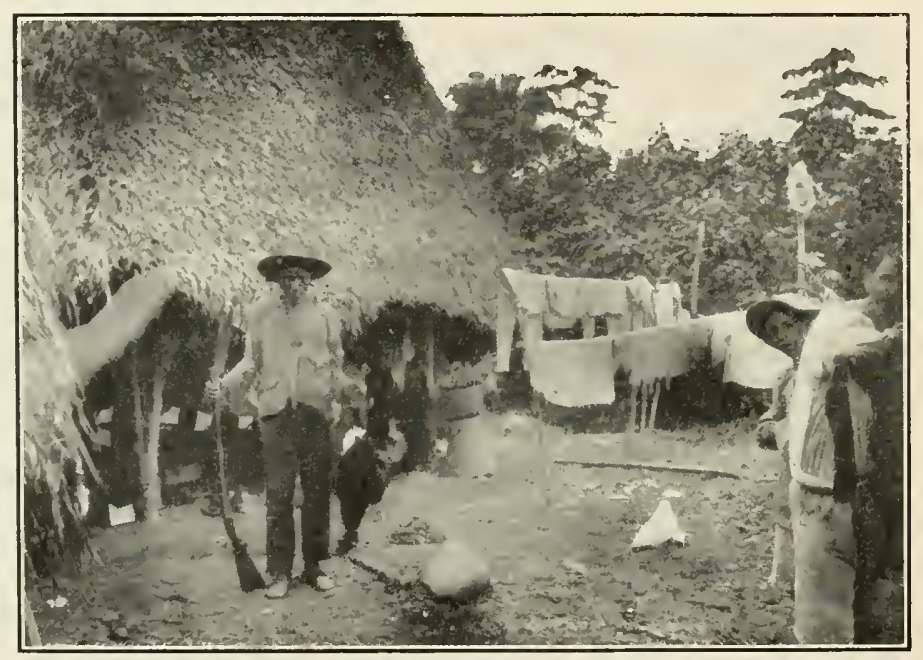

CRUZ, THE HUNTER, WITH WILD TUREEY.

One of the worst rains cance on while we were at llanos, but all were under cover-that is, all except the Prospector and the Scout, who came in drenched and cross because the rest were dry and feasting on mangos and bananas. While it rained Donna Maria was approached with the proposal that she get the Indian woman who lived near to do some washing. She got the woman to come over, but as it was a "fiesta" (St. P'eter's Day), she had religious scruples against working. Nor conld she work the next day, she explained, as that was the fiesta of St. Haul. All of which was solemnly repeated by Elias Ojo. I have not mentioned him before, but he deserves it. He was a boy about fourteen. lunchbacked, withered, with enormous black eyes, and treated 
by all the natives as a most distinguished guest, his comelition leeing due to the fact that when he wats young "a witch holied at him." Leoking at him in turn one wondered what result that losk had wpon the witch.

What with heary rains that malle the trails had and the rivers impassable for a half day at a time. the laziness of the natives, and their habit of disappearing to attend far away fiestas, not to speak of the way the mules harl of hiding in the brush when they were most neederl. we were not getting aheal ats fast as conld be wisherl. So the Prospector and the Miner, with Juancho, the best wooklsman on the peninsula, took the schooner to the (Juebro to arrange for trail cutters, or, better still, canoes ancl men to take us up that muknown river. In the meantime, the rest of us went on with the work of exploration. A few days later the Queloro expedition returned and reported no canoes, no men, and no chance of getting through until the dry season, as the rains were far worse than where we were.

It was during the alsence of the party named that the rest of us went far 11 in the mountain valleys where no white man, even in the time of the spaniards, had been, and preempting an old rubber cutter's shack, we established ourselves in (amp) lguana. We were able to make the jonney most of the way on mule back as an ancient Indian trail passed close to it. The barometer read one thousand feet elevation, but the Castillog was just as plentiful as on the lower lands, and incleed, here were the largest trees. I found also a species of Ficus that procluced a very goos quality of rubher. but was not plentiful enough to have commercial value.

Our party consisted of the Pioneer, the Scont, the Commodore, the writer, three Indians, with one pack mule, besides those we rode. Is there was no feed the mules were sent back to Rio Negro as soon as they were relieved of their burdens. The ride to Iguana, although rough in places was dolightful.

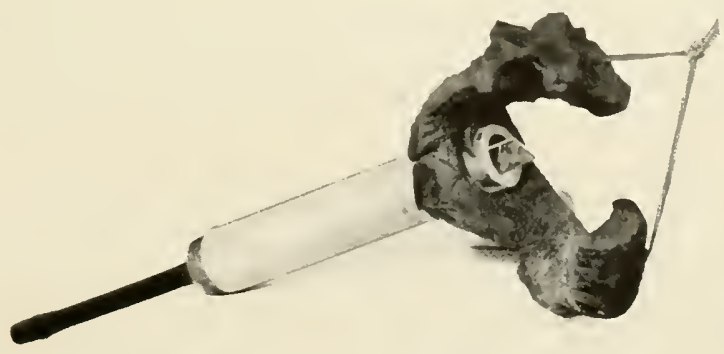

JUANCHO'S RUBEER TAPPING TOOL. 


\section{THIRD LETTER.}

Camp Iguana-Close Quarters-Provisions Low-Lucas Cruz-The Forest Primeval-Bees and Ruber-The Natives' Horror of Gold-A Land IVithout Law-Breaking Camp-Mountain Climbing-At Las Minas-The Plantation "Las Marghartias"-Fourth of July Fiesta-ON Board the Quartos Hermajos Pandia, Colon, and New York.

$\mathrm{T}^{\prime \prime}$

HE ride to Iguana, as I was saying when my last letter came to a close, was delightful. Part of the way lay through dense forest. where some of the trees measured from ten to twelve feet in diameter, then perhaps it was through an abandoned Indian farm, grown up to jungle, but still producing mangoes, bananas, and alligator pears; by climbing hills that seemed to go straight up in the air, and sliding down others that were even straighter: frightening big ignanas and little lizards; stepping gingerly over six-inch-wide columns of leaf carrying ants: always on the lookout for wild pigs, deer, or turkeys to replenish our larder: we proceeded, the whole journey full of variety and incident. The lut at Iguana, with a little repairing, gave us barely room to stretch out comfortably at night, and had any one man chosen to stretch himself diagonally across the pole hed, there would have been no room for the rest. The hut was open on three sides, was about nine feet wide, seven feet high in front, and five feet in the rear, roofed with palm, and had an earth floor. We used our navy bags as hold-alls by day and pillows by night, and slept peacefully, except when our feet went through the side of the hut, or a leak in the roof let in too much water.

Our first meal there seemed the most delicions I had ever eaten. It consisterl of camned smoked beef (the edges of the slices were too far spoiled to eat, but the middle was good), fried bread sweetened with condensed milk, boiled rice, and coffee. The meat was cooked over an open fire and served on big, wild banana leaves. Nor shall I forget the first night-the alnost deafening chirping of the crickets and tree frogs, the queer cries of the night birds, the steady drip of the dew from the trees like a slow rain, and the fireflies-low big and beautiful they were, and how still the air was, so that the flame of the candle went straight up with never a quiver.

To assist in the exploration of this part of the tract was Lucas Cruz. an old rubber cutter, the builder of the hut in which we were installed. 
He lat cone there from across the motntains twenty years before, with his father and five bothers, and harl taken out rubber ever since, selling it to the traters all the way from twenty to forty cents a pound, silver. His figures as to the ancient vield of the trees were rather indefinite. At present, however, as the trees were smaller than of yore, he tapperl

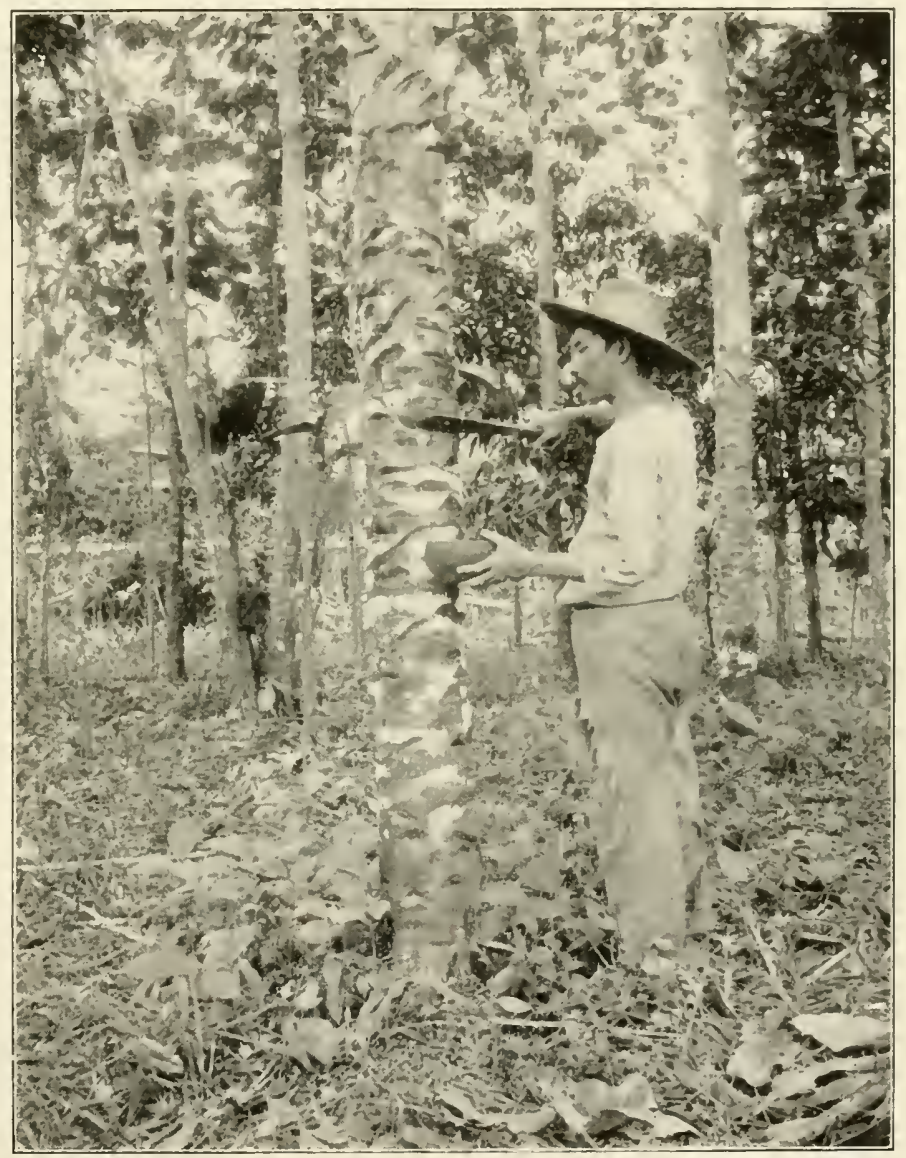

NATIVE RUBBER CUTTER WITH MACHETE IND C.ILABASH.

about thirty in a day and got six to seren pounds of milk, or from three to four pounds of dry rubber. His system was to have a helper, one of the twain tapping while the other collected the milk in a calabash.

Lnder his guidance we got out rery early in the morning. exanined the valleys and steep hillsides in various directions. and found the 
Castillow growing everywhere, and many a stiff climb Lucas gave us before the choice growths were reached. Afterward he explained that he took us only to the easy places, as from some where he went alone, we would never have returned alive. Even up bere I found stumps of hunge Custillous that had been cut down to get all of the milk. The largest trees then standing did not measure more than from sixteen to eighteen inches in diameter, but there were many of them, and thousands of a lesser size.

Pressed later for a definite statement as to what he gathered daily when rubber hunting. Lucas saicl that two years before six of them had, in this region, in seven days, gathered four hundred pounds of dry rubber. As they never work Sundays, that would mean six days

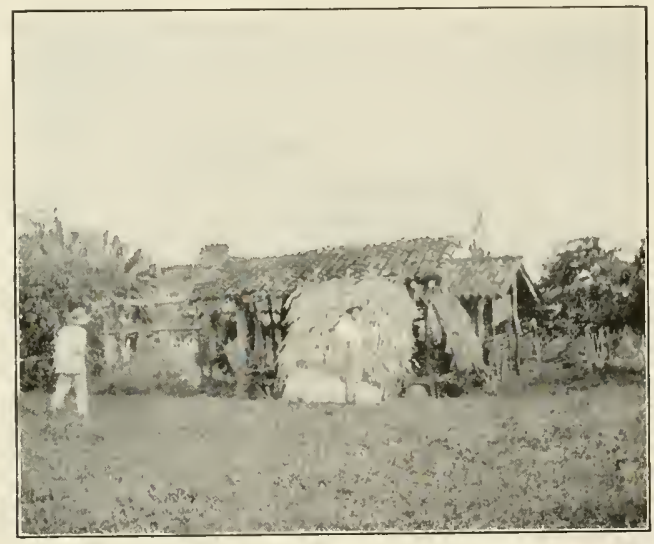

CATTLE RANCH AT THE LLANOS.

[Don Ramon in the Foreground.]

work, that is, unless they loafed three of them, which is probable. For an experiment, we sent out four men late one morning, who were lack by miklay with fifteen and one-quarter pounds of milk that after coagulation and drying made about eight pounds of rubber. As they normally get fifty cents a day, silver, equal to twenty-five cents, gold. that was not a bad return.

It is due to the man who first told how bees collected rubber late. as well as the rubber itself, from the cuts in the trees, that he receive apologies of all skeptics, for the story is true. I saw hundreds in all parts of the peninsula, and they not only love rulber, but almost everything else, and are a great nuisance in camp. What they do with the 


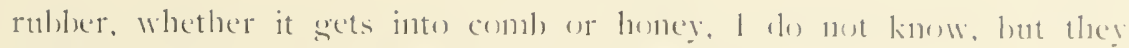
eertainly work most energetically in sathering it.

lig contting down a few trees on the top of a lofty riclue near cample. a fine view of the commtry was developed, from the somec of the vlariats River to the sea, the llamos, the Suoy River, and event the fall away gulf. It was wonderful how lucas could pick ont the Custillog miles away from this eyrie, and withont apparent mistake either.

Ifter a few days at lguana. we began to look anxionsly for the returu of the mules, for food was getting scarce, and worse than all, the coffee was nearly gone. Mlthougl signs of deer were plentiful, the hunter could get nene, and even parrots anel monkers were uot in evi-

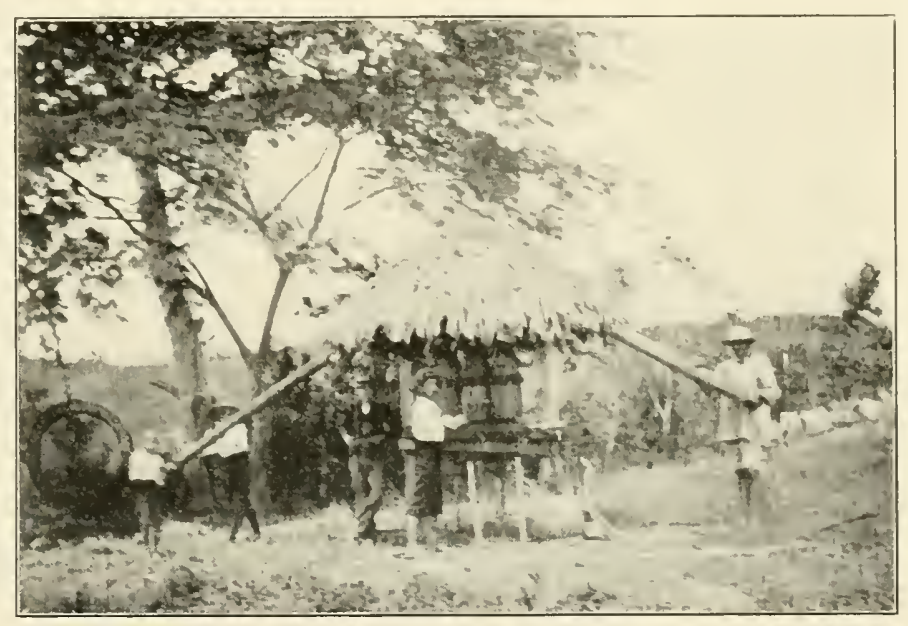

SUGAR MILL NEAR LAS MINAS.

[On Las Margharitas Plantation.]

dence. There was, to be sure, a land crab that the Indlans caught necasionally. It was as hig as a sancer, with a bright blue body. red legs. and eyes set on props an inch long. It was as giddy looking as a Chicago rtmabout, and apparently about as edible. Just as we were tiring of rice and weak coffee, the Pioneer mixed some boiled rice with condensed milk, put it in a small pan on the fire, then laid a piece of tin over the pan, and built another fire on that. In hour later we were feasting upon as fine a rice pudding as ever was cooked. And at that time the pack train appeared, and ere long we were on our way back to Rio Negro camp. 
No incidents of special note occurred on the return trip. The trails were so wet from recent rains that the many humming birds, the gorgeous butterflies, and the rich tropical flowers, were hardly noted. The swarms of horseflies that swooped down upon our patient beasts could not be wholly ignored, however, and soon all became most expert in killing them. As usual, a stray, starving dog appeared from nowhere and silently attached himself to our party. Although we knew he would crawl under our lammocks at night to give his fleas an opportunity to emigrate to richer pastures, he was accepted without protest. He harl his virtues. Nothing conld tempt him to steal, although starving, and he would allow a wild pig to cut him to ribbons that the hunter miglit get a shot, and he was after all the friend of man.

During this ride a strange thing happened: Cruz asked what the

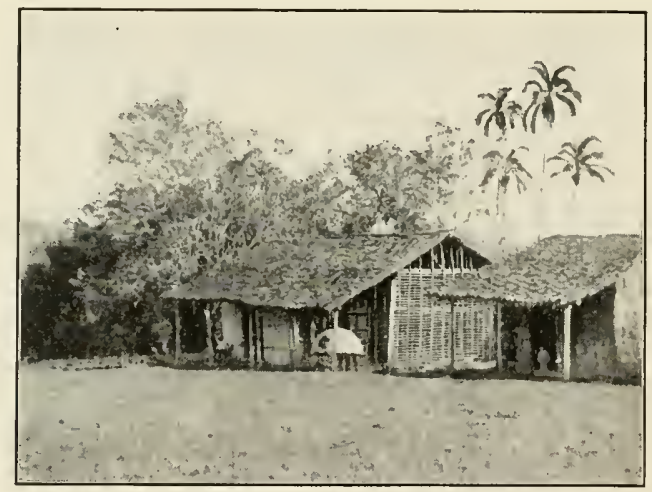

TOWN BAKERY AT LAS MINAS.

Americanos used the rubber for! It was the first tine in the memory of the Pioneer that any cholo (civilized Indian) harl ever shown the slightest curiosity in that direction. I doubt if he appreciated some of the uses described, but the making of waterproof clothing caught his fancy at once. For most of the Indians have a little bay marle of cloth and coated with rubber, mixed with gunpowder, if they can spare it, to help the sun cure it. In this, or a purse marle of iguana skin, they carry flint and steel, a bit of cotton wicking with one end let into a bone extinguisher, and tobacco for cigarettes. They are a quiet, anemic race, very superstitions, and so fearful of spirits and tigres that if overtaken by night in the forest, they climb trees, and tying thenselves to the linnlss, remain until morning. They have a lorror of gold, not 
the coin, but the raw material, ahways denying all knowlerlge of it, the probalule reason heing that the story of the cruclties of the Spanish gold seekers are still in vogue among them. There are, all told, on the eight hundred square miles of the Azuero lands, some four hundred sonls. On the other side of the monntain ranges, however, are large towns and many thonsanels of matives.

It took some time to appreciate that this was a land where practically no laws were operative. As the weeks passed and no word came from the onter world, and we learned that the few letters despatehed to the faraway Panamanian postoffice would never reach their destination, we began to realize that this was indeed a forgotten corner of the world. The natives are all good Catholics, and show their religious

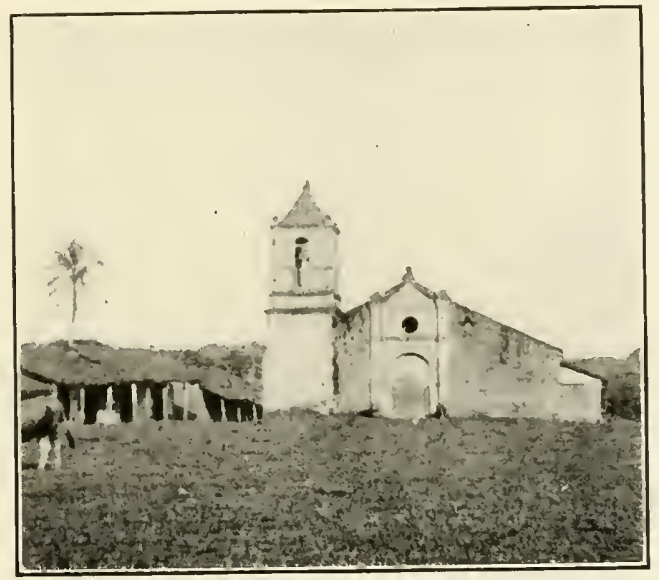

THE CHURCH AT LAS MINAS.

fervor at many fiestas, by burning candles, exploding gumpowder, and getting clrunk. In this latter state they show much energy and put 11] some spirited machete fights. If an Amcricano tries to patch up one of the wounded, they offer no resistance, but as soon as the good Samaritan departs, they take off the bandages, plaster the wound with cow dung, and if the victim dies lay his death at the door of the foreigner. How well I remember the disgust of the scout who wanted to extract a bullet that was just under the skin in the neck of a mozo whom the alcade had shot for some misdemeanor.

"Why it's only under the skin: it will almost roll out," he exclaimed in Spanish. 
Lut they would not allow the skin to be cut, although they did prop the sufferer 11 , heels in the air and head to the ground, and watched all night to see the bullet as it rolled out.

Of the thousands of shell mounds that contain the graves of their ancestors, the natives know little, and cheerfully assist the despoiler to open them and secure such relics or treasure as they may contain.

The women are quite pretty when young, particularly those who live in the mountains, and have a custom of filing their teeth so that the points are as sharp as needles, said to be most becoming, from an Indian point of view. The mountain men who are plysically the best Indian specimens, wear only a shirt and a pair of pants cut off at the knees, and are known in the lowlands as the "short pants."

That night in Rio Negro camp it was really cold. The air was damp, and it was raining heavily, althongl only a little came through the roof. We were sitting about too grumpy to talk until the gray mule took possession of the kitchen, and, in the mix-up that followed. led us to forget our woes. Then the Prospector began to talk about rubber plantations, and my conceit got a shock, for he told me of some that I had never heard of. It was on Gorgonas Island, which lies off the coast of Colombia, owned by the fine old Spaniard, Don Ramon, whom we met in Panama City, where are some five thousand cultivated trees four and one-half years old. The Prospector feared that the revolutionists from the main land might lave destroyed some of them in their periodic forays, but was not sure. Then the Pioneer took the floor. He had formerly been manager for the Darien Gold Mining Co.. and for then he cleared wide paths through the forest in which to plant Castilloa trees. The planting was in part from seed, and in part of young trees, for which he paid the natives five dollars a hundred, in silver. This was in Igoo, and there were some three hundred thousand trees on land some miles from the coast, planted at an altitude of fifteen hundred feet. Since leaving the company, his successor had planted certainly as many more.

The trips that I have ontlined are a few of many, long and short, that taken as a whole gave me a kilowledge of the lands as a whole. The final journey was to be along the "hog backs" that extended ip to the monntains, then over then and down to the further shore. whence the Almirante had been despatched to meet and convey us to Pananna City.

First came the preparations, the most important of which was the packing of the camera supplies. Considering the fact that the runle 
that bore this precions load always fell down when crossing a river, and that the searching clampness of the atmosphere harl been at work at the films for many weeks, it is a wonder that any pictures at all were obtained. Then cance the drying of clothing and a supply of hrearl. The l'ioneer tried his hand at bread baking along the lines of his rice puddling trimple, but the resulting solid cakes, scorched on the outsirle, and dough within, conkl not he honestly temed the staff of life. Py splitting open and toasting them they were edilsle, and were eaten, all but one. Which I saved for a paper weight.

On Sabado (Saturlay) morning at 6.30, we broke camp and

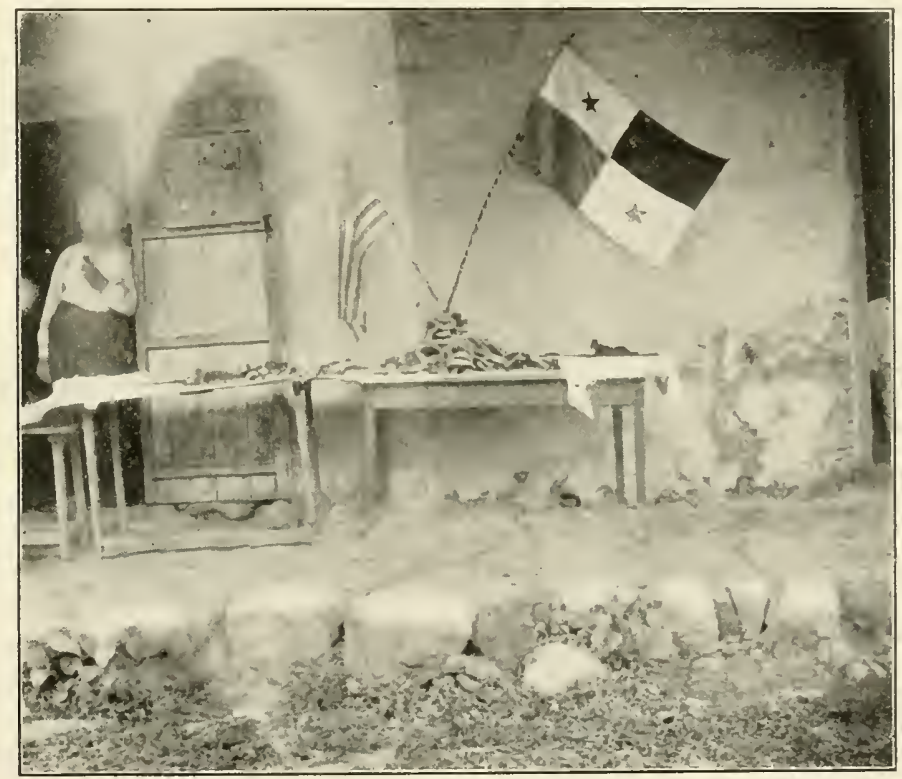

FOLRTH OF JULY FIESTA AT LAS MIN.AS.

started on what our guicles claimed would be the hardest day's work we had ever done, and it was. There was only one river to ford, the Mariato, and Chicpuita, knowing little beast, kept her feet, while the other mules and horses were stumbling. plunging. and threatening to go down stream with the swift current. Then began the steady climb. over a trail that was like the bed of a brook. through unclerbrush that tried the pack mules sorely, often stopping them completely until freed by the use of the machete. I had an army saddle on Chiquita and a 
rope bridle about her nose, but the first could not be cinclsed tight enough to stay on, and the latter was only a matter of form. Pull all I could, she went where she thonght the trail was best, and in all fairness I must say she was usually right. I do think, lowever, when she insisted on crowding so close to a sharp stub pointing down the trail that saddle and rider were both ripped off, instead of slipping her hind legs ont of the cinch and continting on after the rest, she might have waited. I certainly gave her to understand that I advised the other side of the trail, and in response to my vigorous pull her head came round until it almost touched my knee, but the obstinate little body went straiglit on.

Sone of the "hog backs" climbed were of the razorback variety-just a narrow path along the spine of lofty ridges, forested on both sides, and incredibly steep. The gray mule got in difficulties on one, lost his balance, curled up and rolled over and over until stopped by a big tree and a tangle of monkey vine. He lay at ease until relieved of the pack, then struggled to his feet and climbed back to the path, not in the least ruffled.

It must not be supposed that the trail went up all the time; on the contrary, it was a quarter of a mile up, then an eighth of a mile down, and we rode sometinles lying flat on the beast's back, at others with feet along the sides of the mule's neck and leaning as far backward as possible. Many a rod did Chiquita slide down clayey steeps, but not a misstep did she make through it all. We lunched by a brook in a deep valley where the dense shade made twilight of high noon, and then went on, the climbing worse than ever. The first signs of rebellion on the part of the beasts of burden came from the mula grande who bore the Commodore. He thought it was time lis rider walked a little, and while the Commodore paused to reason with lim the rest rode on. Very soon the way becane so steep that all dismonnted and walked. While catching breath at the top of a particularly stiff bit, we heard the Connmodore coming, puffing, panting, profaning.

"Where is your mule?" I asked.

"Blank the blankity blank beast, lue won't even allow we to lead him, let alone ride!" he exclaimed. "Refuses to associate with me, blank liim!"

And so it was. Mula grande appeared a few moments later, halted a rod away, and when approached, simply stood stock still. If the Commodore swore, he put his ears forward so as to miss none of it, and if he fell to belaboring lim with a cudgel, simply began to eat of 
the herbage with an ait of mencern that would have tempted many to slioot.

About five oclock Chepo, the pig ranch, where we must spend the night, was reached. We were tired out but happy, for in the menusy of the oldest inhabitant never had that journey been made without enconntering a heavy rain storm on the top of Montoso (over which we cane), and we had come through dry. Hammocks were swme in a big half rumed pigshed, a chicken was cooked and eaten, and we turnerl

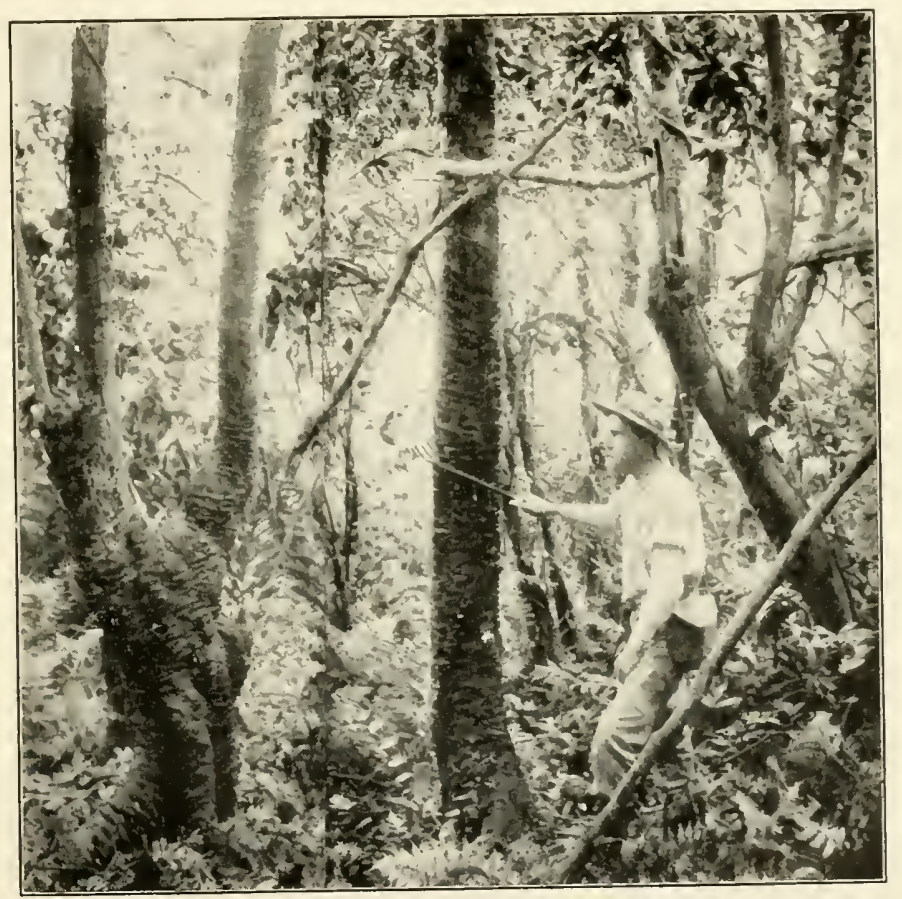

WILD "CASTILLO.," SHOWIXg STEMP OF BIG TREE FROM WHICH SPROLTA H.AD GROWN.

in. The aneroid said two thousand nine hundred and fifty feet for altitude. It was quite cool. but deliciously dry as compared with Rio Negro.

Up at five the next moning. after a hasty breakfast of Pioneer"s bread and coffee, the climbing was continued. Here there was less forest and the trail was centuries old. In places it was worn down in the red porphory until the sicles rose above the rider head. while at the hottom it was barely wide enough for the mule to walk. It was also often cut 
into by a series of from three to five foot steps, with a pool of water in the hollow of each, so the difficulty in getting along may be imagined. Finally the top of Cerro Nuncio was reached, three thousand five hundred feet in the air, and laid out before us like a map. were the plains of the other side of the peninsula. This mountain. so said the Miner, was a mass of gold bearing quartz, and a part of the property we were examining, but we left it where it was. After a rest we started down towards the town of Las Minas which was to be our recuperating and repairing station. The descent was far too steep to ride. so we climbed down, finally reaching the plains, and a little after noon, we rode into the old Indian town. Here, installed in a house owned by the Pioneer, we were soon sitting at a table, using knives, forks, and napkins, as if we harl always been accustomed to thent.

This narrative relates primarily to rubber, and it is hard to forecast just how much extraneous matter the reader will stand. But it is only fair to the writer to allow him a word concerning a part of the world which Christopher Columbus. Duke of Veragua, chose for his own, as it was his province. V'eragua, that we then were in. Not only that, but all the Indians of his time were Spanish slaves, and the amount of work that they did in digging down mountain sides for gold, is marvelous. Las Minas, founded by the descendants of Columbus, has its plaza, church, tiled houses, dogs, children, and buzzards, like all Central American towns. It also has several fine Castilloa trees, and not far away an extensive Castilloa plantation. The latter is known as "Las Margliaritas" and is owend by the alcade of Las Minas. It consists of about twenty hectares of land, planted with rubber and coffee. There are said to be some twenty-five thousand Castilloas, that for age would average about three years. One tree that was ten years old was sixteen inches in diameter, and bled freely, but the latc.r was waxy, and did not coagulate until the wax was worked out. This was not the case with all, and I think the difference was individual.

In our conversation with the Indians we learned all that they knew of the land just explored. They confessed that they did not like to go over there, as they were afraid of getting lost. They also boasted of the times when their grandfathers crossed the mountains and, filling canoes with late.t. used them as coagulating vessels, and very hesitatingly, and only after very much persuasion, they told of the sold some brought out and of the "lost mines" that had once produced such riches for the Spaniards before the Indians rose and massacred them.

Fourth of July came while we were in Las Minas, but it would take 
pages to tell of the fiesta that we gave the town, and of the buile they gave us in return. It this baile the alcade played the first violin, and was accompanied by a mantolin, a triangle, and a native drum. All day long the whole population was shonting lia't Independenciu Estados Unidos! and we in turn liza Independencia Panama!-while Amigos Americanos and Amigos Pana-something or other-were swapped back and forth most fraternally.

Visiting the old Spanish mine, the Golden lock, now being developed by Americans, we learned from the natives that at times a golden cock crows, and then all the dead men killed lyy a cave-in during the

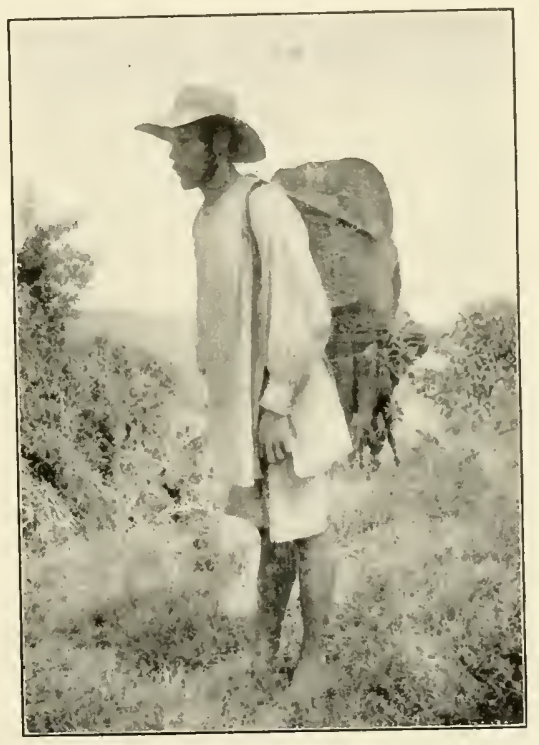

INDIAN PACK BEARER.

Spanish occupation, groan in concert. A golden bull that is somewhere inside of the mine also has a habit of roaring when certain calamities are due.

From Las Minas came the journey to Pesé, a town of some five hundred inhabitants. Here the Pioneer also had a store, and his home, where we were entertained most royally. We did not tarry long. however, as the Prospector was already suffering from painful tropical boils, and it seemed necessary to get where there were physicians. From Pesé we went to Chitré on horse or mule back-all except the invalid, who rode in a bull cart-and finally arrived at Innocentias Hotel. I 
was about as near a wreck as one could be, for Chiquita on level ground developed into the fastest, hardest gaited little trotter that I lave ever seen. She simply would not canter, and in her trot she kept up with the galloping horses and pounded me almost to jelly.

At Chitré we expected to find the Almirante, but she was not there. After waiting two days we took passage on the Quartos Hermanos, the Prospector being brought aboard on a mattress. It must not be thought he was the only danaged one, for all of us were sonewhat battered. I had a scalp wound an inch long that I had secured by going through a doorway at Innocentias without stooping enough to avoid the sharp tiles, the Scout had a cracked rib, because his horse jammed him under a leaning tree, and the Commodore had a touch of fever.

The Quartos Hermanos got away late, by poling down the narrow, muddy Parita River one and one-half miles to the bay. At the river's mouth, we met the Almirantc, and, leaving the Commodore to guard the luggage, boarded our own boat. It was liard work to get El Capitan to turn about and follow the other schooner-why, I don't know-but it was finally accomplished. But alas, hardly were the schooners a quarter of a mile from shore when both were aground. Half an hour later one could walk on the hard, black sand from one boat to the other. It would be flood tide by midnight, and if there was wind that would mean a race for Panama. So I offered our captain ten dollars, silver. if he got in first. By eleven our boat was again on even keel: ten minutes later she was under way, the breeze freshening every minute. It finally got so fresh that I could not sleep on deck but went below. With the exception of one hour's calm the wind held all the next day, and at midnight blew us into Panama harbor. But the shrewd old Portuguese captain of the Quartos Hcrmanos beat us an hour by getting to the windward and then sailing like a streak.

It was just sunrise as we dropped anchor in the bay opposite the Hotel Marina, from which picturesque hostelry many hoats put off to secure the job of putting us and our belongings ashore. This task was accomplished after much haggling, and within an hour we stood on the beach surrounded by our luggage, objects of much interest to a score of watermen. half as many dogs, and a lutge drove of wild pigs that had just been unloaded from a small freight schooner. One more hour on the beach sufficed to purcliase porters and a cart-I say "purchase" advisedly-and start our helongings toward the hotel.

Once again at the Hotel Grand Central, where were stored nost 
of our clothes, we prepared to assume the habilinents of civilization. The first thing was to induce the hotel management to open the bathroom and furnish water. After a forenoon of persuasion that was finally accomplished, and we felt better, even if the hotel employés disl not. Then followed a visit to the cable office, a second exploration of the city, and preparations for passage to New York, on the goorl ship I'ncutan, which was to sail, and diel sail, on the day following.

In our journeys about the city and along the line of the canal, I tried as far as possible to get close to the people-that is, in the way of mental, not physical contact. Of the native Panamanians I found some exceedingly well educated and active, sane, business men. They were, almost without exception, most pronounced in favor of the annexation of the young repullic by the Lnited States. The mass of the people, however, apparently wish only to be let alone, and resent the lustling ways of the Americans. I should say also that there was an exaggerated idea, in their minds, concerning the prowess of the Americans, particularly the trim looking marines who walked the streets as if each indiviclual conkl put an army to Hight.

That the canal would be put through and in less time than is generally helieved, all of the business men were agreed, and that both Colon and Panama City would one day, under the American engineers, be free from yellow fever and as hahitable and safe as Singapore or Harana none doubted, but that either city would be of great commercial importance once the canal was finished was not predicted. 

EXPERIENCES IN COLOMBIA 



\section{FAIERIENCLS IX (U)LUIII.}

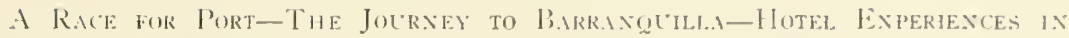

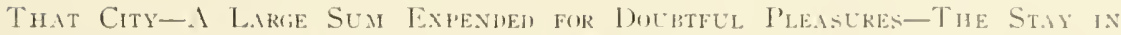

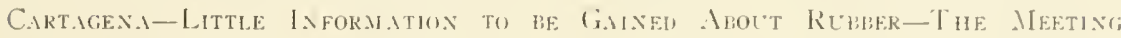

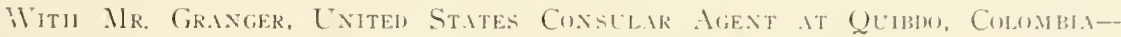
His Interestixg Semany of the State of the Indestry ind IIs Prophecy For the Future.

I Thad been wy fortune a number of times to observe the picturespue crast of Colombia from the sea, on both the Atlantic and F'acific sides, but up to the time that the good ship. Sarmiu landed we at Savanilla I had never set foot on its sacrel soil. It was, therefore. with mucl interest that I stoos on deck and watched the approach

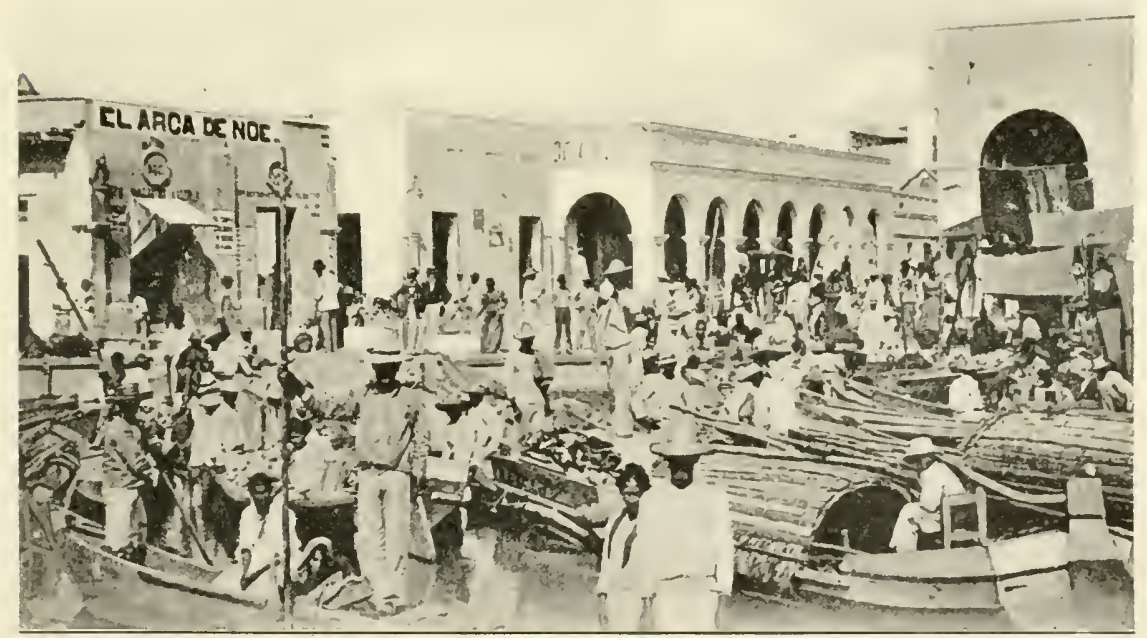

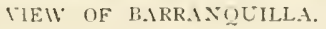

of the ressel to the three hundred-foot iron pier that is about all there is of the "Port of Colombia." There was, to he sure, a cluster of huts about the litle railway station: huts that seemed to grow up out of the desolate shore much as the cactus and mesquite did, without any lumman intervention, but the result rather, of a dry. creative impulse of some arid desert god. 
We had been shouldered and buffeted for several days by the restless Caribbean, scorched by the sun and wilted by the heat, and we were glad of the prospect of getting ashore. We therefore entered in spirit into the feelings of our captain, who was racing with a French steamer for a good mooring, and whose Tentonic oaths we piously echoed without linowing exactly what they meant. Whether this helped in the race is a questicn, lint at all events we got the berth, and as we were making fast the captain joined our group. His good nature was restored, and as we stood under the awning, not much bigger than a pocket handkerchief, sheltered from a shower, he called attention to a man standing on the pier who was General Somebody, and a personage of great importance.

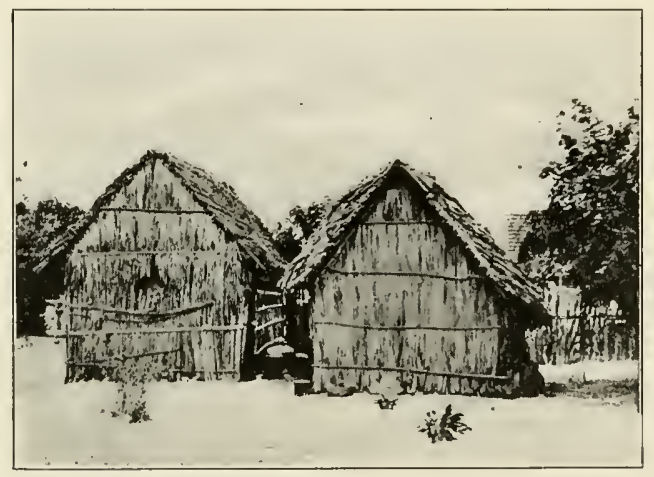

HOMES OF THE POOR.

"You mean the chap in the mackintosh?" asked an English shipmate.

"No, the man in the rubber "goat," "growled the captain.

Both of them stood pat, and the argument lasted long after we left them and stepped upon the pier, which was crowded with freight cars, natives, sailors, and the nondescript Anglo-Saxons that become residents of such places and never get either money or energy enough to get away. Did I say that it was Sunday when we landed? Well, by the calendar it certainly was the holy Sabbath, but so far as we could see, no one observed it but ourselves, which we did by rigidly abstaining from work, and preparing to journey up to Barranquilla early Monday morning. This town, which is some nineteen miles away, is connected with the port by a jerkwater railroad that has great difficulty in negotiating two trips in twenty-four hours. We therefore made all 
preparations, and as I was the only one who knew how we ask for three tickets in spanish. I was electerl treasurer, and full of confirlence approached the ticket office with the demand, "Tres boleto Barranquilla."

Ifter much conversation and considerable sign language, 1 discovered that single fare was eighty-eight dollars. romel trip being seventy-four dollars: so 1 bought round trips. thus saving forty-two dollars. The price seemed a little high, but it gave us an added respect for a corporation that could secure such prices.

Taking our places in the passenger coach which was about fifteen feet lomg. with exceedingly narrow sides, we were bestowed as comfortahly as might be. We three were the only Americanos, and the Colombians, particularly those with the store tecth, which secmed to be quite a farl. smiled at us benignly. We were unable to sit tugether. ancl

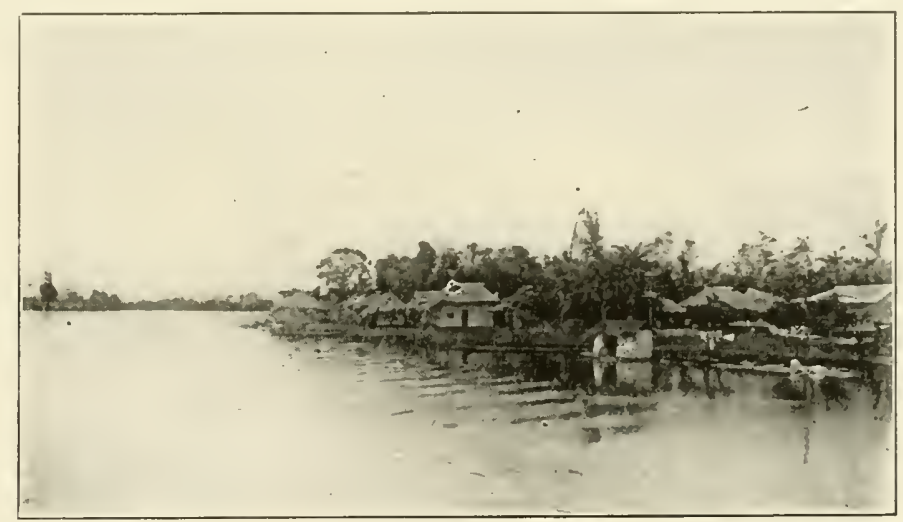

MOUTH OF THE SINU RIYER.

to one fell the luck of being seated by the side of an exceedingly dark complexinned lady with much adipose tissue. who shook with the motion of the train so that we feared her calico swathings would give way and she would run all over the floor: while between her and our companion sat a perfectly naked boy about six years old. I have forgotten how the rest of us were bestowed, I was so interested in watching the disgusted look on the face of the crowded one.

When the train was loaded and everything ready, we had the usual South American wait of about half an hour, and then finally, after much protesting on the part of the fussy little engine, the train dragged slowly along the wharf, around by the station. and following the shore took its way through most uninteresting country until we reached 


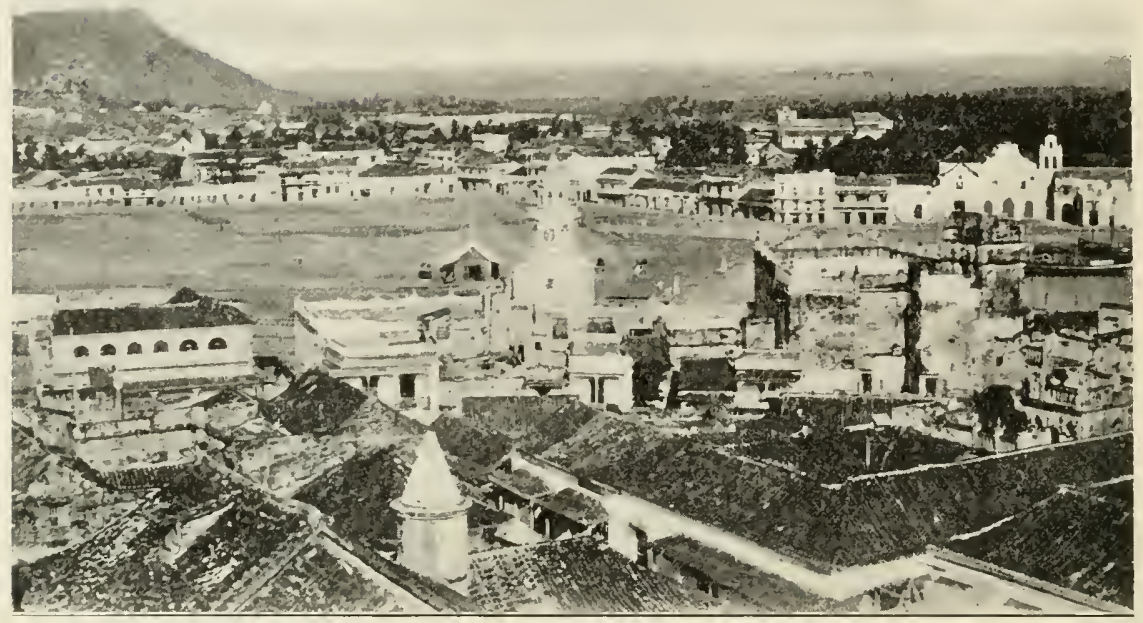

PANORAIIC IIEH OF CARTAGENA.

Barranquilla. This proved to be quite a city, Spanich-American throughout. and unspoiled by the tourists. Around the station were two score of rickety carriages, to which were attached, by rusty and nondescript harnesses, a collection of horses, carlaverous and dispirited in the

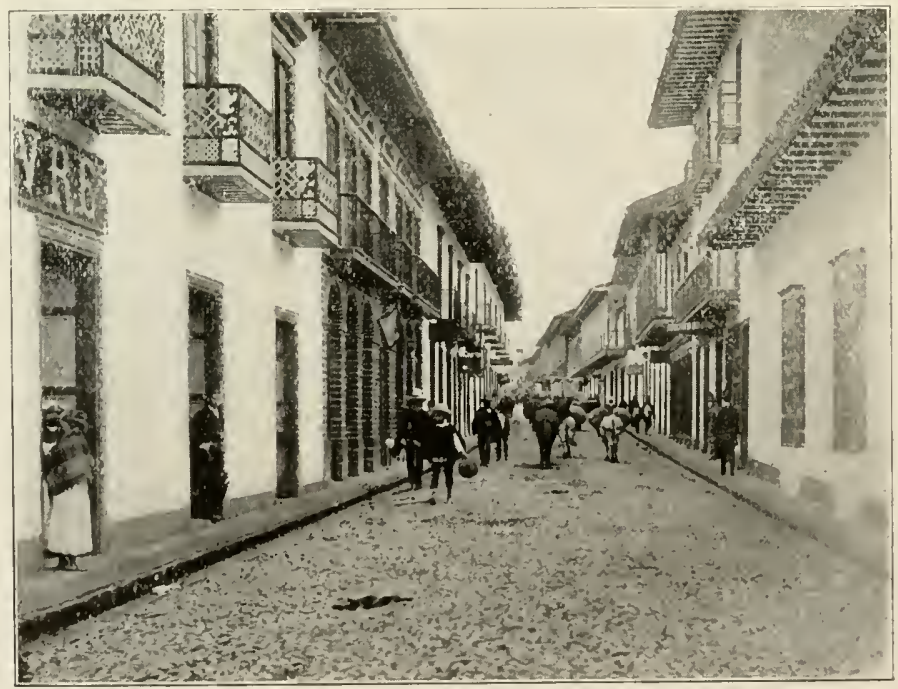

SCENE IN OLIEUC, A RUBBER TRAJING (ENTER. 


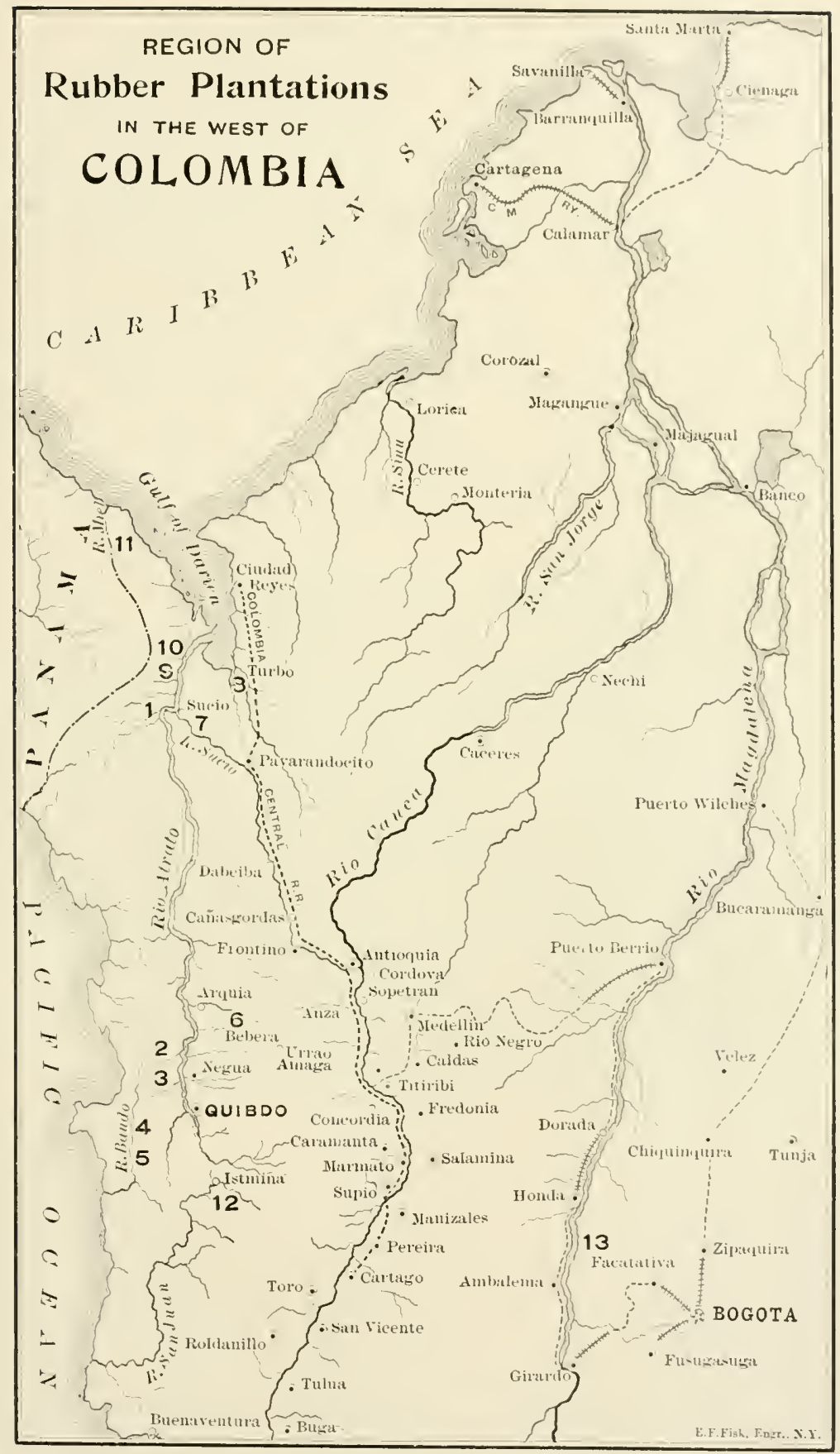

FIGLTES IN THE MAP RELATE TO THE LO ATION OF RLBBER PLANTATIONS (MEATIONED ON ANOTHER P.AGE) BELONGING TO THE FOLLOWIXG:

1. Juan C. Olier.

2. Ciceron Angel

3. Carlos Nicolas Ferret

4. Gonzalo Zuniga.

5. Melink \& Co.
6. Delfino Diaz

7. Mantuel Rios

8. Louis Gonzale:

9. Abuchar Hermanos.
10 René Granger

11. I,oni- M. Sanıamaria.

12. Francinco De B Carasco.

13. "I.e Barrigona" - De La 
extrence. Two of them succeeded, however, in getting us and our luggage to the Hotel Anglais, rum by an English woman. where we secured a room. It contained four beds, a passage way between them. a washstand, and a broad balcony overlooking the street. The heat was really terrific and the sandy streets of the town shot it up into the rooms until it seemed almost umbearable. Our stout companion by this time lad a splitting headache, so we put him to bed and began to take care of him. I secured for him a cup of tea, part of which he drank. Another got him a glass of lemonade. which seemed to do him more good than the tea, and then for the moment he felt so much better that we got a waiter to bring him wp a light meal, after which, discovering that the hotel afforded ice cream, he had a plate of that. Then lie began

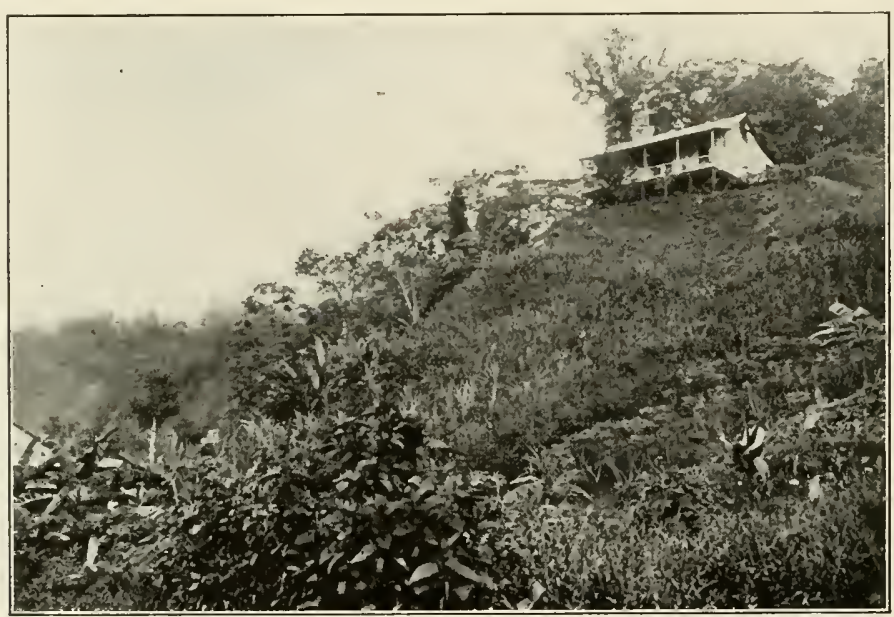

COLOMBIAN SCENERY.

to feel ill again: indeed. I think he would have refunded all he had eaten had I not shown him the bill, which was itemized as follows:

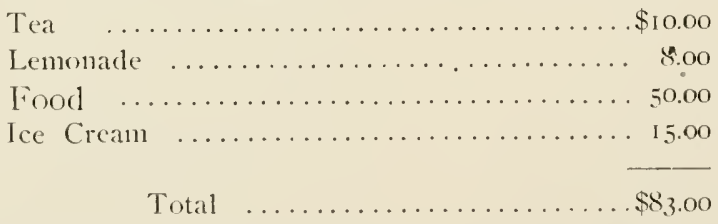

Thrifty New Englander that he was, he subdued nature, and in a swelter of perspiration annonnced his intention of keeping what he hasl paid so high for. 


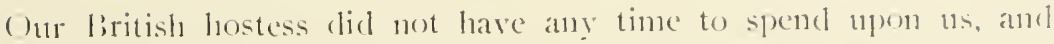
as English was an unknown language in the town, we were toubly fortunate in making the acquantance of Julius Ciesar \islal, a coffece colored, barefosted urchin, brought uj, in Jamaica, who spoke Fuglish fluently and meloclionsly. His presence so cheered the sick one that he sudelenly became convalescent. Iost his hearlache, wot up and joined us while we did the town. Julius was indeed a treasure. He explained everything to us briefly and quaintly, and incilentally gathered at his heels onc-lualf of the populatian of the town. who cared not a whit for us but who wanted to hear him talk English.

That night we dined in the main rining hall, but my appetite was

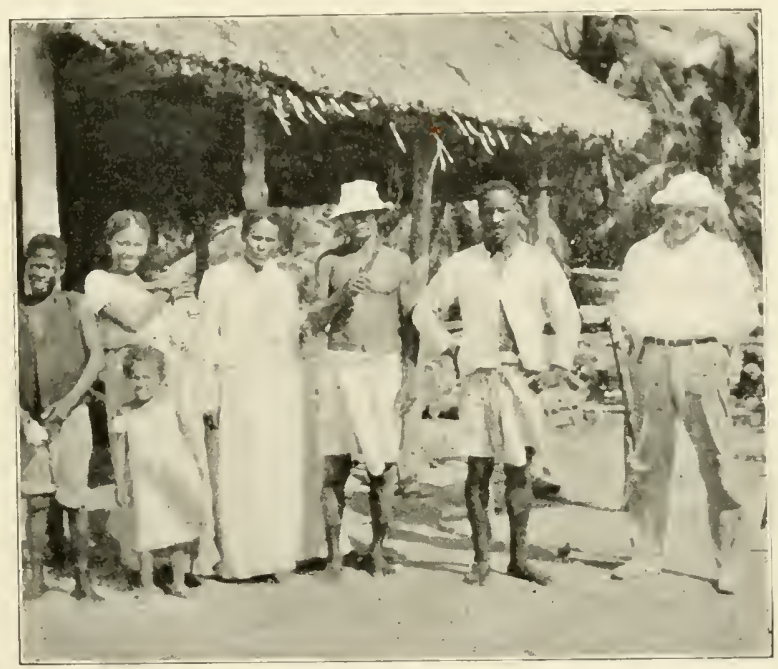

LUMBER AND WILD RUBBER CAMP.

spoiled by a sign on the wall which read: Ice cream. \$15.00: sliced ham. \$45.00; ox tongue, \$100.00.

After dimner we walked aromul in the cool of the evening. bought some Aztec pottery warranted to be genume, and later retired to onr room. It was then that we began to appreciate the deadly stillness of the tropics. The dog fight that started in the hallway ended in our room, as the combatants fell against the door and burst in. This. mingled with the evening song of several cats, the katydid chorus, and the constant whistling of the police patrol, soon lullerl us to sleep: that is, accurately speaking, it lulled one of us, who, when he once lost 
hinself, had the whole tropical chorus beaten to a standstill. As an originator of strange gasps, groans, sobs, and strangling snorts, he ontclassed anything that we had ever heard before, and while we did not sleep, we lay and listened, filled with are, as in the presence of the emperor of all snorers.

In the norning, desirous of showing on appreciation of what Julius had done for us, we asked him to name his own reward, and he decided that he wonld like a pair of shoes. We therefore purchased for him for thirty dollars a pair of stont leather shoes, and for fifteen dollars more a pair of stockings. Then loath to part with him we gave him money to purchase a ticket to ride down to Savinilla with us and

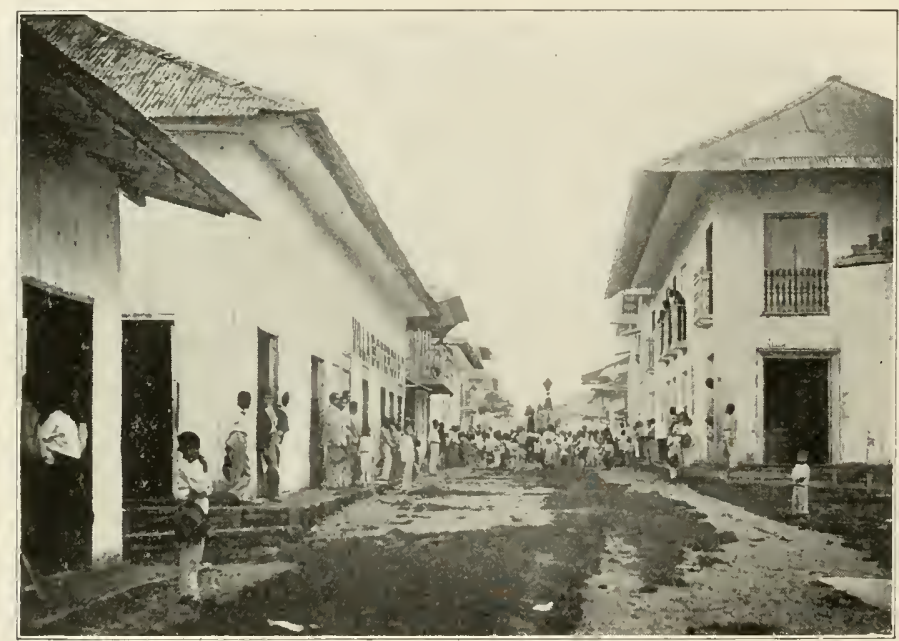

MEDELLIN STREET SCENE.

see 11 off. This he did in the thriftiest sort of fashion by buring a third class ticket, round trip, for ten dollars, and entering our first class car, calmly putting hinself under our protection, ignoring the expostulations of the outraged conductor. We found incidentally that the fact that Julius went away with us eansed a wave of indignation to run throughout the town, as they believed we had practically abducted him. A British friend, also, who had remained aboard the steamer, was very much surprised to see the treatment that we accorded Julins, and asked an explanation of it, in reply to which the Mannfacturer sairl, jocosely:

"Hin and me is partners." 
"I an sure you are, from your srammar," replied the liriton, with a sarcastic emplasis that was delightiul.

We had dimner on the boat, and after clinner 1 rendered an accomt of my stewardship, which the figures show:

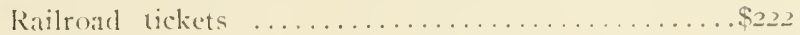

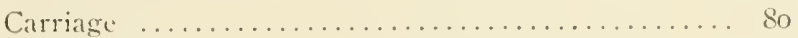

Three lemonates ...................... 24

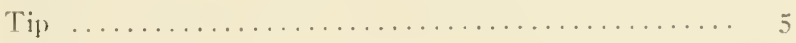

Miscellaneous, ...................... 150

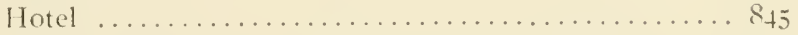

Ticket, Julius ..................... 10

Total

$S_{1336}$

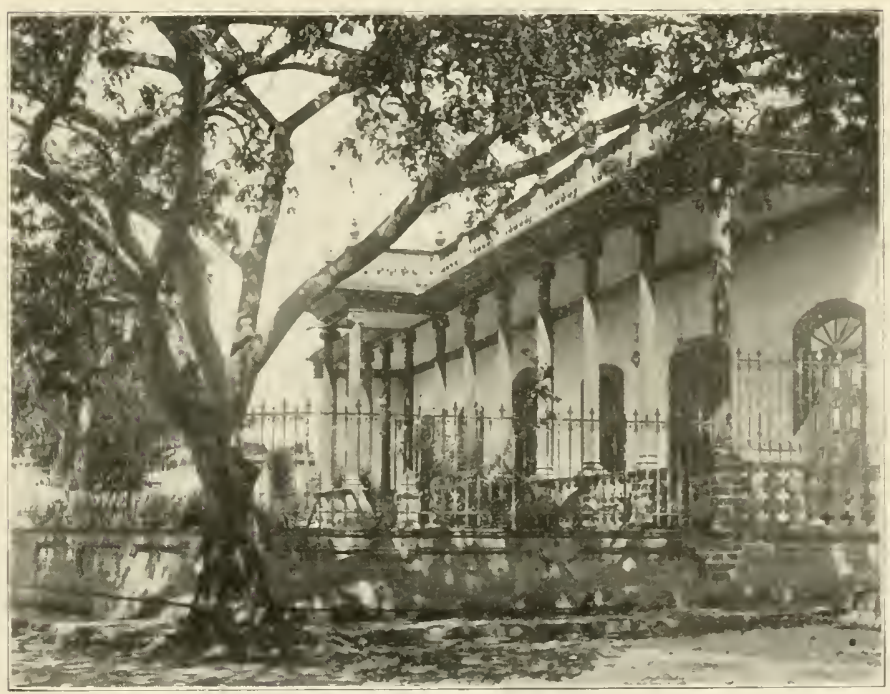

MEDELLIN-HOME OF A WEALTHY CITIZEN.

. 11 this money for twenty-four hours of doubtful pleasure! I have forgotten whether I remarked that one dollar of Lncle Sam's money was readily taken by the Colombians for one hundred dollars of their own.

The reason for the great depreciation in Colombian currency is said to be that twenty-five years ago Colombia comed both gold and silver which circulated at par, but the law allowed all debts to be paid in silver which was the cheaper, and in a very short time gold went out of use and became a subject for speculation rather than a circulating medium. 
We got away at eleven oclock that night and on the following morning were out of sight of land, continuing so all day. As there were no ladies aboard, and as it was exceedingly hot, we lived in pajamas and came nearer to being confortable than we had at any time for a week. It was told us incidentally during the day by one of the officers that the report had gone abroad in Parranquilla that the President of the Lnited States had heen assassinated - a report circulated probalny ly some one who was feeling sore about Panama. The matter furnished a clay"s

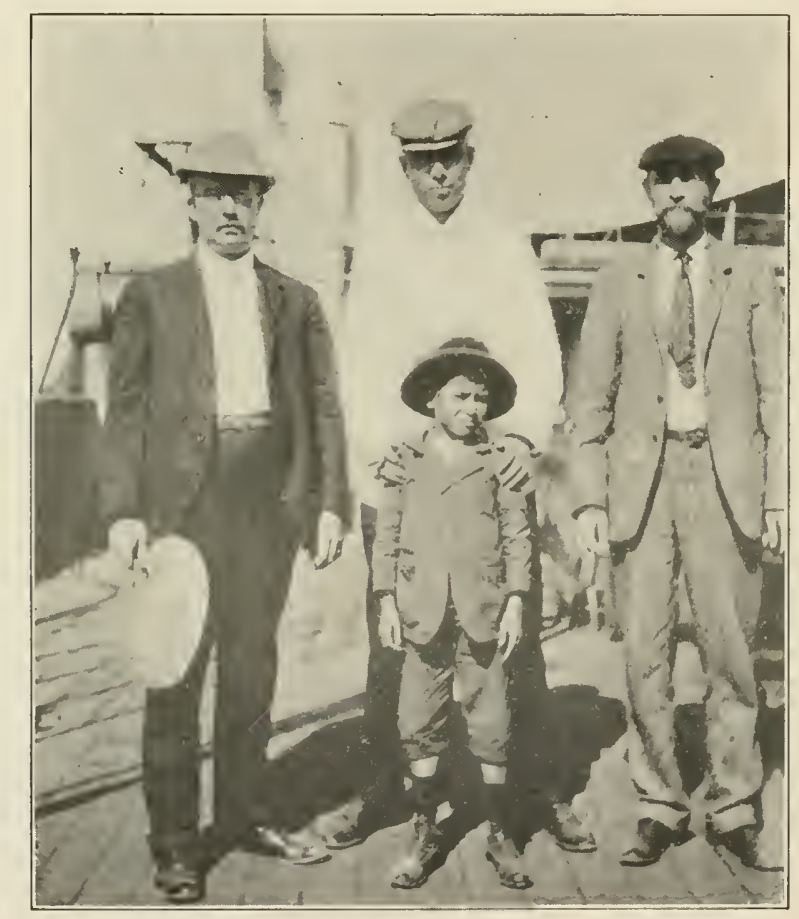

THE WRITER (ON THE RISHT) INI HIS (OMPINIONS HE VOY.IGE.

TThe boy is Julius Citesar. I

excitement, until the arrival of the next steaner confirmed its antruthfulless.

The following morning found us at the entrance of the harbor at Cartagena. We entered by the old Spanish forts, passing groves of palns, coming into a leautiful stretch of harbor. where fronting us lay the ofd walled city, huilt close to the water's edge, with a background of tree clad heights, a sight picturesque and beatutiful, and a wonderful cont- 
trast to the Colonbian towns we loarl just left. Making fast to the pier, the steaner was at once surrounded by dugonts, in which natives with monkeys, parrots, coral, etc.. tried to tempt money from the reluctant pockets of the passengers. Getting ashore we tork a short raibranl ricle to the midelle of the city and breakfasted at the Hotel Americano. Even here there were few Anglo-Saxnns. Indeed, one of the storekepers to whon we harl letters of introduction saicl at that time that there were only seven Anericans, four Englishmen, and three (icmons in (artagena. The old city was fascinating

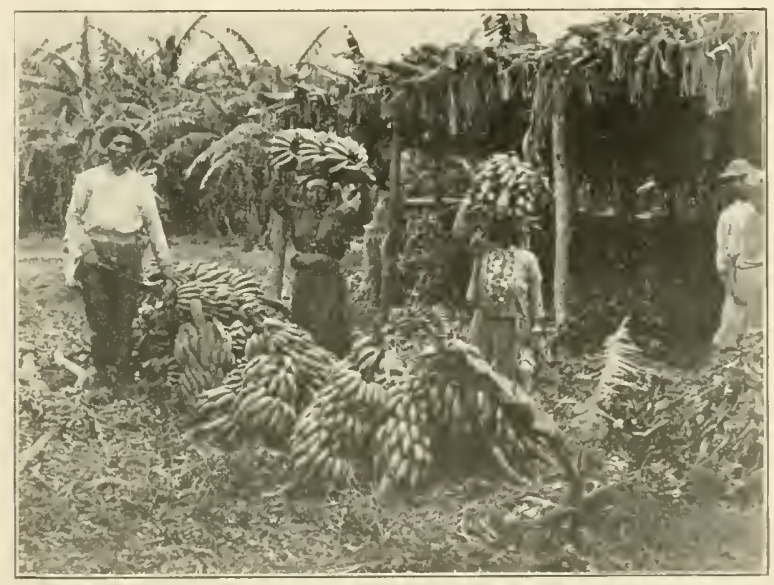

1.1X.1. IS.

in the extreme, and we spent erery moment that we ound spate in viening the walls, the catherlal, the fortifications, and the public buildings. We also went up against a mative manufacturer of P'anama hats. and each bought several of them. Inciclentally: of course, we looked for rubber, but found that there was rery little in town. Incleed, few knew anything about rubber any way, either wild or cultivaterl. A young Plitadelphian who went down with us reported that on his company"s concession. which covered some two hundred square miles, the natives had cut down nearly all the rubber trees. and that that sort of work hat followed throughout the whole of their district.

It was a very fortunate accirlent that at this juncture brought me in touch with Mr. Henry (i. Granger. Cnited States consular agent at Quibdo. Colonbia. and it is clue to his instant good will that the following reoord is here appended. 
Quibclo, by the way. on the river Atrato, in western Colombia, is a town of some commercial importance in that region, as well as a political center, being the residence of the prefect of one of the provinces. The term, "the Choco," mentioned by Mr. Granger, is a legacy from the former days, when a province existed by that name, derived from an ancient Indian race called the Chocos. The region referred to now, however, forms a portion of the present department of Cauca. Mr. Granger's information follows:

"Thirty years ago the production of wilcl rubber in the Choco amounted to several million pounds per year. The trees were cut down and bled to the branches. As the wild Castilloa here runs a free latc.r, it is gathered in kerosene cans, or holes in the ground, and is brought to market in solid cakes. Owing to the destruction of the trees, the

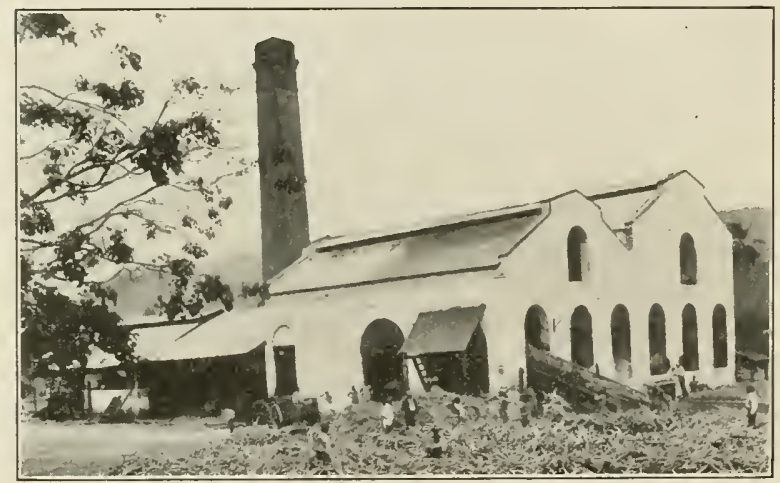

SUGAR MILL.

output steadily fell off and the cakes became adulterated by earth and non-elastic saps mixed in to make weight, until the business became pretty well discredited, and relatively nonimportant. Then attention began to be called to small lalls of rolled strips, chasa (pronounced chassa). brought in by Indians and occasional negroes, which were taken from cultivated trees by cutting the bark with machetes at intervals of a few inches, as far as a man conld reach. The cultivated trees are called "borroso" as they give a thick latc.t" which rums but a short distance down the trunk, and is gathered, when dry by tearing off the strips and rolling then into balls, or packing in boxes in which case they dry in the form of the receptacle.

"Practically all traveling in the Choco is done by water, and soon 
canoes began to arrive bringing only chawt, as this class of rubber, in view of the superior price it brought in the foreign markets. was pairl for at much higher rates than the orlinary cales. This stinulated the negroes, and about nine or ten years ago they legan to plant rubber, mitil toxlay, of the estimated population of eighty thousand negroes in the Choci, he is the exception who has not, if not bearing, at least a few dozen trees planted. And sone of them have as high as four thousand trees in a plantation.

Now, in the rubber shipped from Choco, the cale is the exception and chase the rule.

The products of the Choco are shipped by the steaner Condor ancl a number of dory shaped schooners to Cartagena on the Atlantic coast, and by dugouts to Buenaventura on the Pacific. The only two ressels

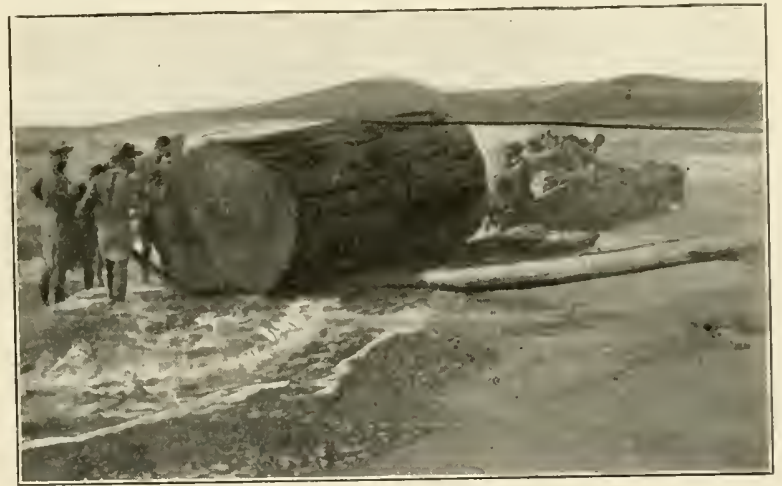

LU MBER.

which have kept a record of their classified freight for the past year are the steamer Condor and the schooner Tulia. Inquiry from their owners resulted in the statement that they carried. during this period, seventy-une and eighty tons of rubber respectively. As there are a number of other schooners which run to Quilulo and are known to bring rubber, it is entirely reasonable to place their entire total at that of the Tulia, or a general total to the port of Cartagena of two hundred and thirty-one tons per year. Señor Luis Durier of the firm of Zuniga and Diaz, at present manager of their Cartagena house, who has had extenflerl experience in the province of San Juan, says that unquestionably this region ships as much as the Atrato. But if it shipped far less we would still have a product of over a ton a day, the great majority of which is chusa, or the product of standing cultivated trees. 
"It is an accepted fact that in five, or even four years, if well cared for, a rubber tree in the Choci will give a total annual product, of various cuttings or tappings, of a pound of chasa, and that if care is taken not to injure the tree, this amonnt will annully increase. The commerce of the Chocr is in the hands of the white race, who live in the principal towns. Many have gone into rubber planting, and some

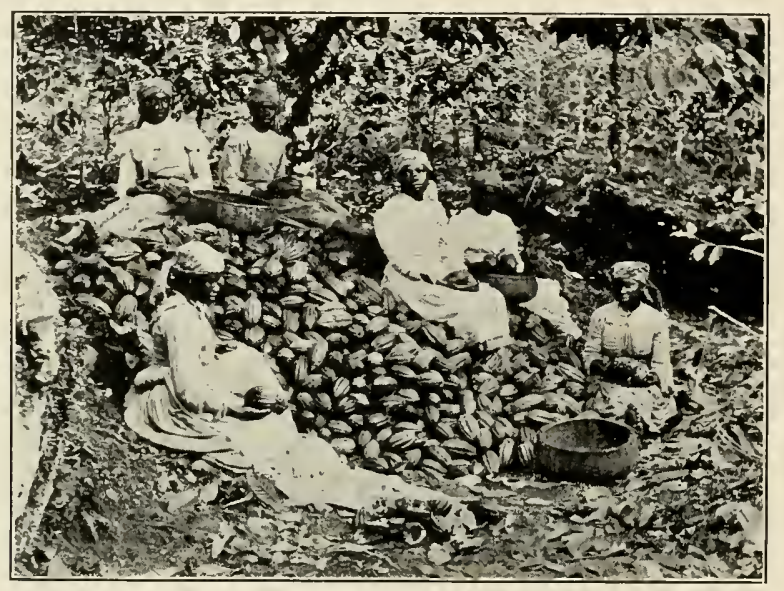

CACAO.

esteem their plantations more than their mercluandising. Anong the principal ones are:

Juan C. Olier, Rio Sucio, Atrato, Colonbia.

Ciceron Angel, Quibelo, Atrato, Colombia.

Carlos Nicholas Ferrer, Quiblo, Atrato, Colombia.

Gonzalo Zuniga, Quibrlo, Atrato, Colombia.

Meluk \& Co., Quibdo, Atrato, Colombia.

Delfino Diaz, Quiblo, Atrato, Colombia.

M,anuel Rios, Rio Sucio, Atrato, Colombia.

Luis Gonzales, Turbo, Atrato, Colombia.

Abuchar Hermanos, Sautata, Atrato, Colombia.

René Granger, manager, Yankomba, Atrato, Colonnlia.

L nis M. Santamara, manager, La Carolina, Lraba, Colombia.

Francisco de 1). Carrasco, Istmina Choeo, San Juan, Colombia.

- wot to mention the hundreds of small plantations of much larger ageregate than the above, whose planting will amount to probably about three hundred thousand trees, all of Castilloa except at La Carolina, 


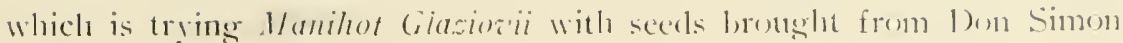
de la Torres's ranch La Barrigona on the npper Magdalena, which in turn brought seeds from (eelont.

"It is foumd that rubber to thrive in the (bece must be planter in the sum, and the acepted distance apart is four to five meters. The construction of the Colombia (intral kathoat from the (julf of Urabe (Darien) to the interior will open nu, a lot of rubler hand in arklition to the areas alreatly alcessible. Lantana raising, quarty mining, and gold dredging are industries of great promise bere, but none of them will surpass the rubler planting lusiness if the present enthusiasm continues, and jurlging from the ontlonk it will." 

A FLYING TRIP TO JAMAICA 



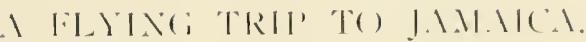

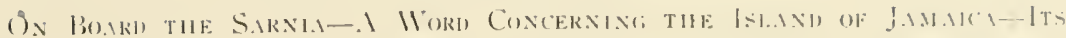

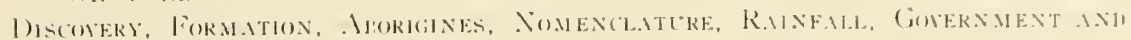

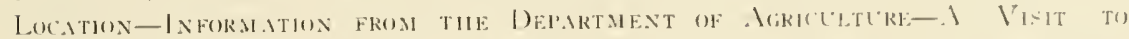

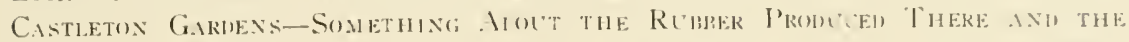

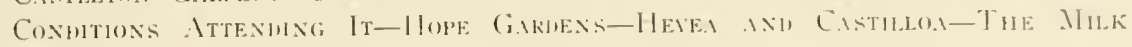
WITHE.

IAMAICA-peaceful, Certile, rich in cheap, free labor, and close to the Lnited States throngh location and language. will some day, perhaps very soon, be an exporter of India-rubber gathereel from annual crops. The beginning of experinental planting may be even before this book goes to press-hence the story of the island. brietly told.

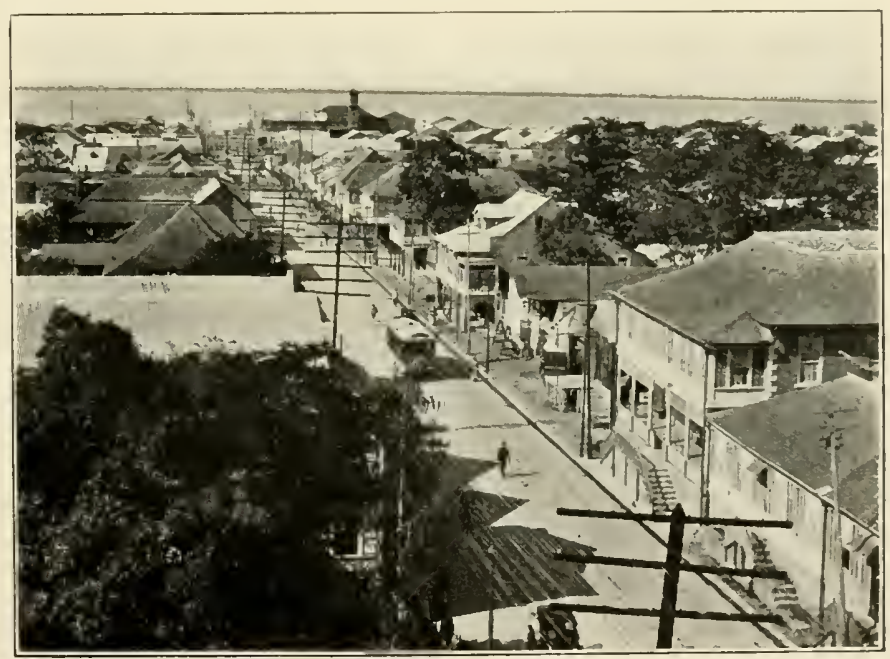

KINGSTON STREET, KINGSTON.

I had long wished to risit it and see for myself how it sized up as a place for planting rubler. This wish was intensified when Professor N. L. Britton, director of the New York Botanical Gardens. leased the English tropical experiment station at Chincona, and assured a future for Anerican botanical work in which rubber can lardly be ignorerl. I was more than glad, therefore, when my jumrnevings marle 
it convenient for me to stop and have a look for myself. We left New York late in November on the Surnia, which was crowded; so much so that one of our party, planning for my comfort, wrote a few days prior to the start:

"I have ordered the upper bunk in Stateroom Twenty-one made up especially for you, with a delicate blue counterpane, with little blue ribbon bows on the pillows which I think will match up with your beattiful complexion very well."

Newspapers, however, have special privileges, particularly when the Editor knows the agent of the line, so I was able to secure a roony cabin by myself, but alas, without the delicate colored counterpane and ribbon.

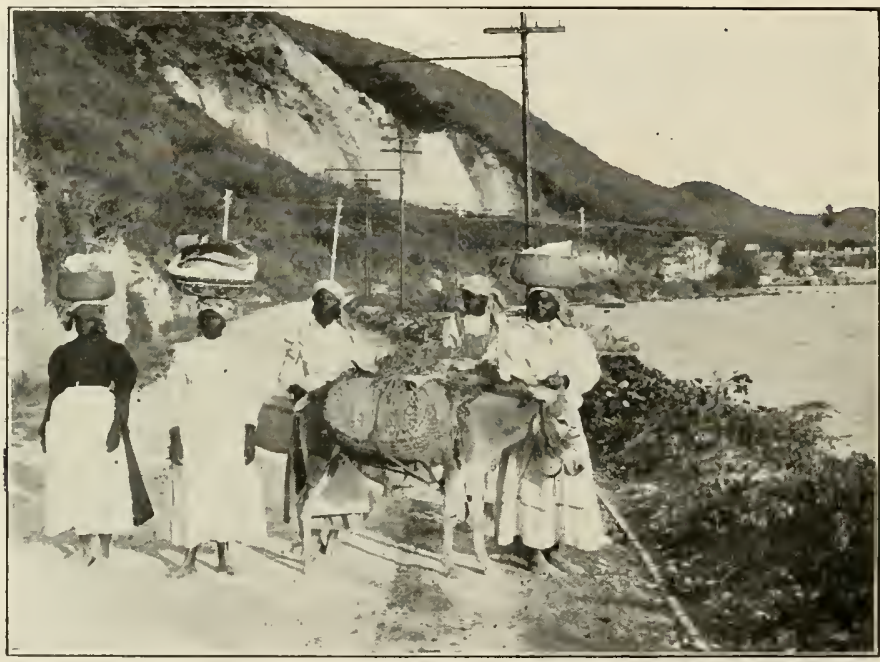

COLNTRY NEGROES.

We got off in a snow squall, stopped for an hour in Gedney Channel to ease up on a hot bearing, and then we put out to sea. It was not too rough to have the port holes open, although an occasional big wave slopped in. Our fellow passengers were a circus troupe on a two years circuit around the world, via South American ports; some mining and lumbermen bound for Colombia, and a miscellaneous lot of tourists. One of the lumbermen confessed to owning a small plantation of Castillou in IIonduras, but was far from enthusiastic about it, as he could not keep the natives from stealing the rubber, poor though the yield was. 
As we got further south it lecame warmer very rapilly, and som sweaters and heavy suits were kaid asicle. At Fortune lsland we took a lot of Jamaica negroes aboard, and one evening they came to the promenarle deck and gave a concert. It was rery darkeyish, but not half so musical as what the Anerican plantation negroes (d). () ff the coast of Cula the temperature on deck was eighty-eight degrees lahrenheit, and in my caldin, ninety-cight. It is muncessary to state where I spent most of my time.

Now just a word concerning the place we were to visit. The island of Jamaica was disenvered in ifyt hy (hristopher Columbus, who was

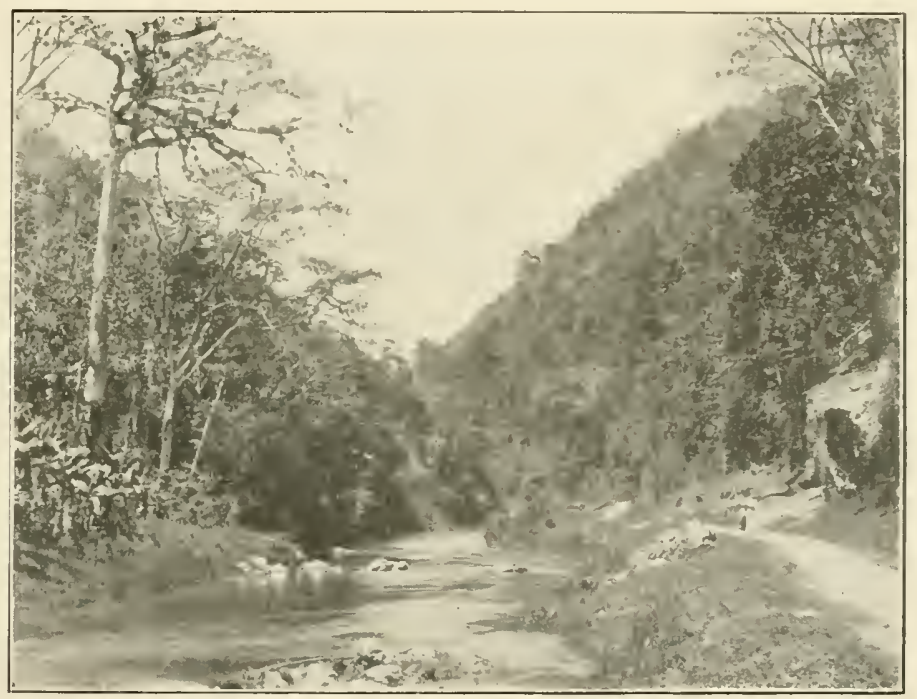

BOG WALK

very much taken by its beauty, and delighted with the politeness and good nature of the natives; so much did he and his followers appreciate them that within a few years they had robbed them of all they had and practically exterminated them. The island, by the way, was not known as Jamaica in those days, but as Chab-nlakia, from two Indian words meaning wood and water, or in the thouglit of the Indian, "watered by shaded rivulets." The Spanish softened the word to Chamakia. and in turn the English made it Jamaica.

In 1654 the English captured the island and began to colonize it. For many years they sent their convicts there to work for the planters. 
but in 168 y the labor situation was such that the government recognized slavery, and for a time all was peaceful. There were several revolts, however, on the part of the slaves, one occurring in 1760 , when sixty planters were killed and half a million dollars worth of property restroved. The rebels were finally subdued, and as a warning, one of the ringleatlers was burned at the stake and two others were put in iron cages and allowed to slowly starve to death. In I83t the British govenment insisting that the slaves be freed, arranged an apprentice system for the 311.000 slaves, by which laborers in the field were to work six years more and then be free: while domestic laborers were to work four years more. The crown also paid thirty million clollars

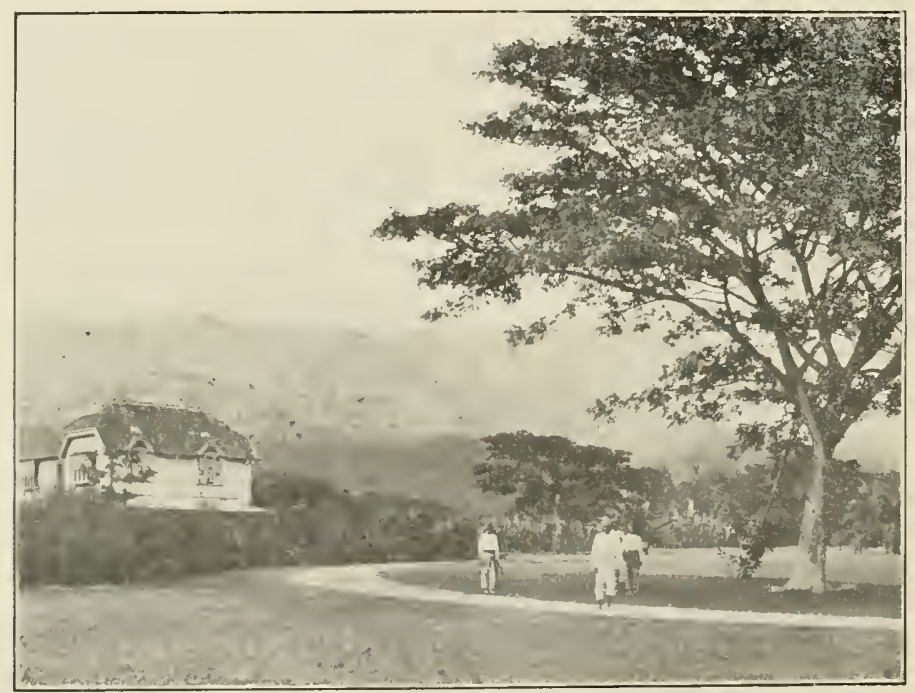

ENTRINCE TO HUPE IOTANICAL G.ARDENS.

indennity to the owners. After leeing freed, the slaves became English st1)jects with all their rights, and it is only fair to the black race to say that they have progressed remarkably; as well. perhaps, as whites woukl have done under the same circumstances. To show the proportion of whites and blacks on the island, figures from the last census are given as follows: IThites. I4.692: colored people, I21.955; blacks, 488, 24 : and 1 t.000 East Indians, Chinese, ete.

The "Jamaica nigger" at home is not a very hard worker, but he is sood natureel, self respecting, and in many cases thrifty. The island floces not afford enough work for him, and so they are to be found all 
up and down the coast of central America, where they are very promel of the fact that they speak linglish, and that they are free men.

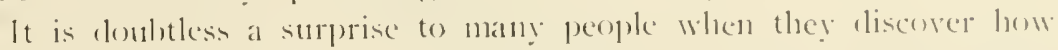
far south fantaica really is. The island lies directly oppusite (ape Gracias a Dios on the Nosquito coast of Nicaragua, amel it is so situated that when the Panama Canal is finisherl, it will lee a most impurtant strategic point. The chief business of the island is planting sugar. coffec, hananas, ete. The natives work as a rule irom seren in the morning until four in the afternom, with an hour ont for noon breakfast. They rarely work Saturelays. The average paly for field labor is fifty cents a ray. The island, although only one lumelred and forty-

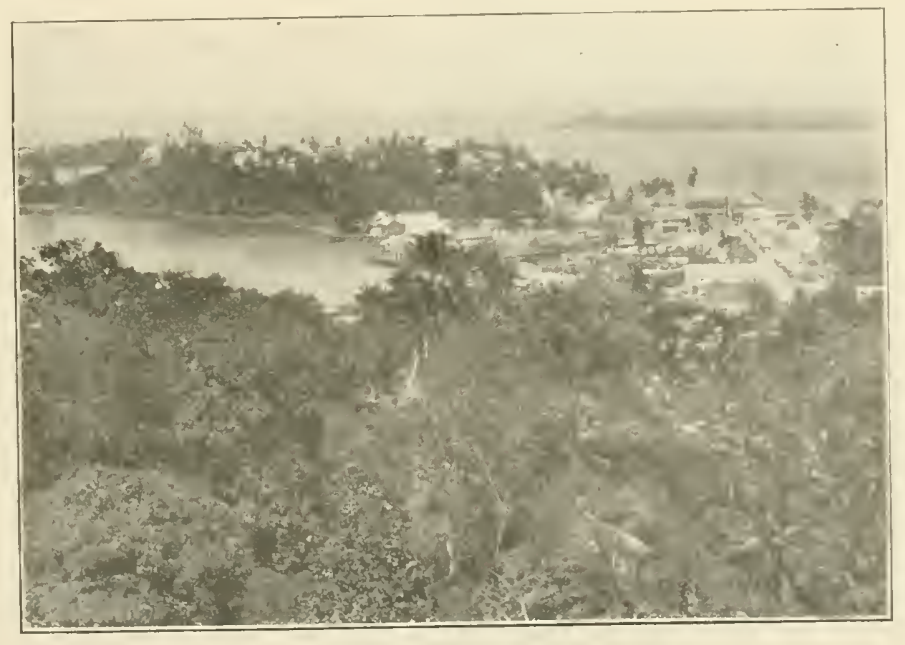

PORT ANTONIO.

four miles lo ne and forty-nine miles wisle. las a climate varving from tropical to temperate.

(One of the first questions that the prospective rubber planter alsks is. "What is the rainfall?" In no way can this he answered so comprehensively in the case of Jamaica as by the accompanying rain chart reproclnced from "The Rainfall of Jamaica." hy Maxwell l Iall, M. ... F. R. A. ... F. R. X. S., and published hy the Institute of Jamaica. The mean rainfall for the whole island annually is sixty-six incles. The northeastern end. however. has an area where the rainfall is one hundred inches and over, shown ly the darkest portion of the chart. Northwest of this there is a tract where it is from seventi-five to ninetyfive inches which is inclicated lọ the next lighter sharle. The 


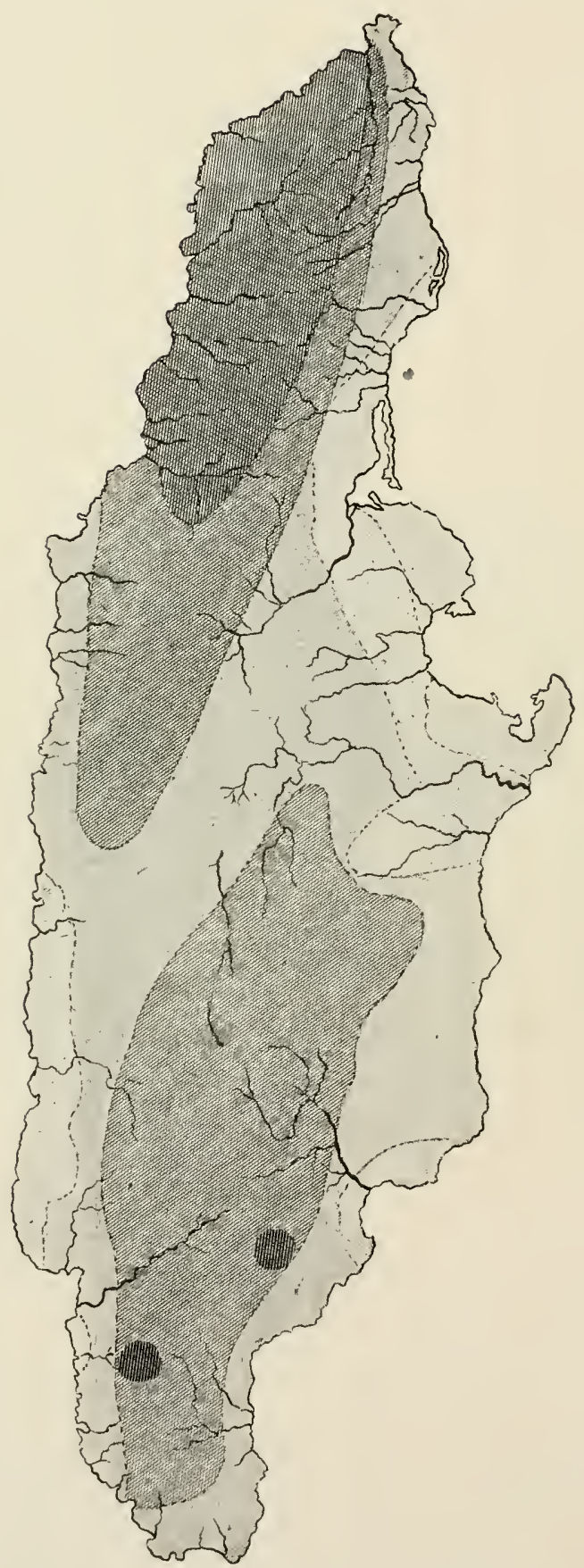

MAP SHOWING AVERAGE RAINFALI, OIER JAMAICA FOR ONE YEAR. $\hat{n}$ 
western central portion las a larese area that runs fiom seventyfive to ninety-five incles, while all along the cuast and a strip throngh the midldle of the island, there is only from forty to fifty inches, and in places thirty to thirty-five. It will thus be seen that the planter can get almost an! rainfall his crops may need. The island is of volcanic origin and indeed. has been, within the menory of man, visiterl by severe earthquakes. The formation is coral, white and yellow limestunce, and in some places, trap rock. In the river valleys there are some quite rich alluvial areas where excellent crops are prodticed. There are many thousands of acres of crown lancls not yet taken up, which are disposed of to settlers under exceedingly favorable terms.

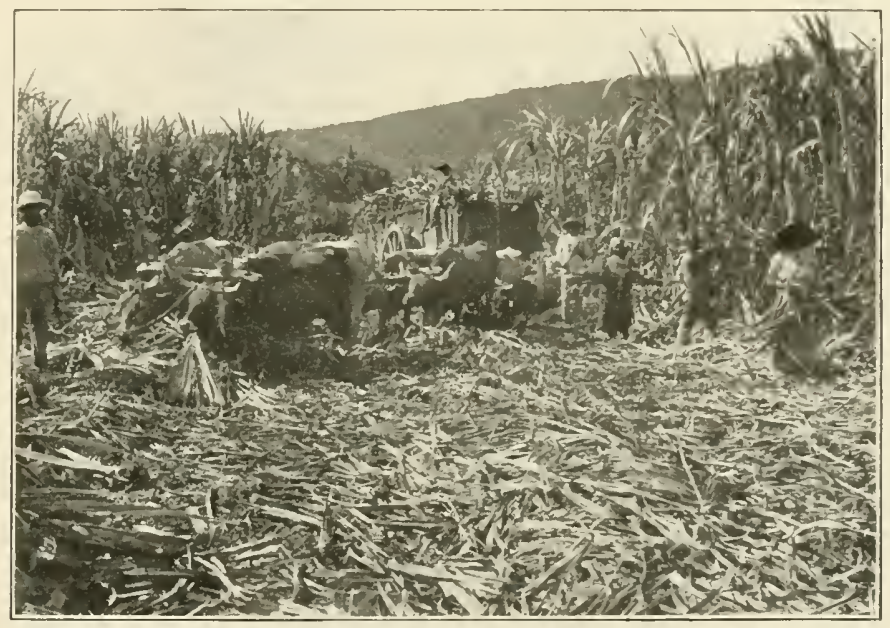

SUGAR CANE FIELI).

Tery early in the morning we passed the old Spanish fort at Port Royal, entered the harlur, and at seven oclock were tied up at the pier in Kingston. The wharf was crowded with ebony-colored "Englishmen," who bore themselves with much dignity. Pushing through them we made our way to the Myrtle Bank Hotel, where a good hreakfast was discussed, and then we did the town: that is, until the sun got a bit too hot for walking. As I wanted to get all the official information possible, we looked up the Department of Agriculture. In a short time we were fumished by the very capable secretary with maps, rain charts, reports and practical information that told pretty nearly all we wisherl to know. The officials were most prompt 
and polite, and really saved us days of hard work in what they furnished $11 \mathrm{~s}$.

The printed matter was good, but we wanted to see rubber growing, and therefore took the nineteen-mile trip to Castleton Gardens. These gardens, established some forty years ago in what was supposed to be a sheltered valley, would, if more money were spent upon them. be of great value to the whole of the West Inclies. The average temperature at the gardens is seventy-six degrees Fahrenheit, and the rainfall. I I . o7 inches, annually. The first ten miles of the journey was by excellent trolley cars and gave us a fine chance to view the country.

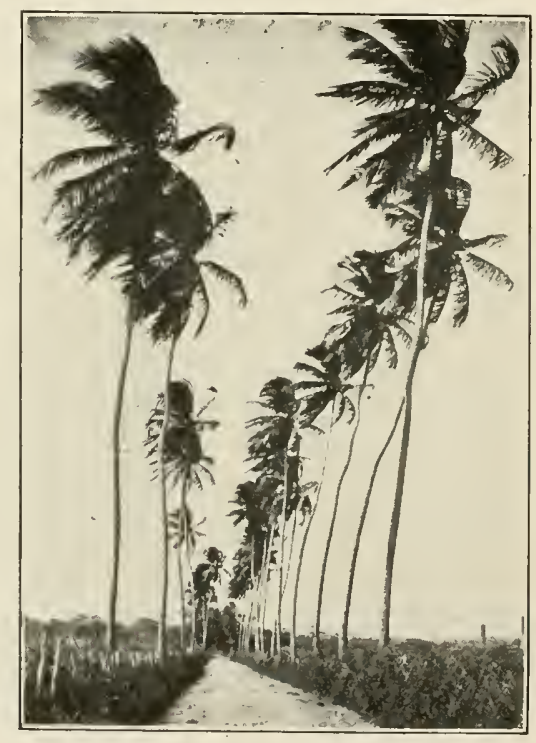

COCU.INUT PALMS.

The product most abunclant was, of course, the banana, grown in hig and little lots for the Lnited linit Company. At the end of the trolley line was the Constant Spring Hotel where we secured carriages for the rest of the journey. The way was hilly, but the roads good. and the soil although not apparently rich. scemed, under the influence of the sun and the abundant rainfall, to be very productive.

The gardens were in a measure a disappointment, as they are not large, and have a neglected look, except in parts. This is due to lack of money and not lack of interest on the part of the caretakers, the whole appropriation for the uplicep being fifteen dollars, gold, a week. 
Unfortunately when the first real experiments in rubler culture in Jamaica were undertaken, the cearat tree was selected as the hest fitterl for that climate. As far as can be learnerl, the tree behaverl exactly ats

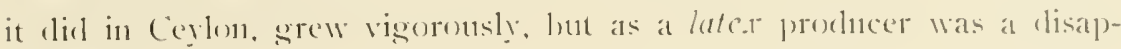
pointment.

There were several specinnens of licus elestica and Landolphius as well as some fairly good custillows. The rublue trees that gate the

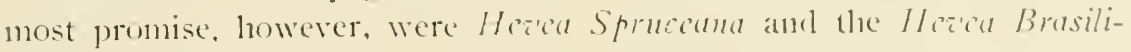
cusis. The Sprucenu was partiandarly thrifty and gave out good latex abundantly. The rubber frem it was of a lighte vellow color and very

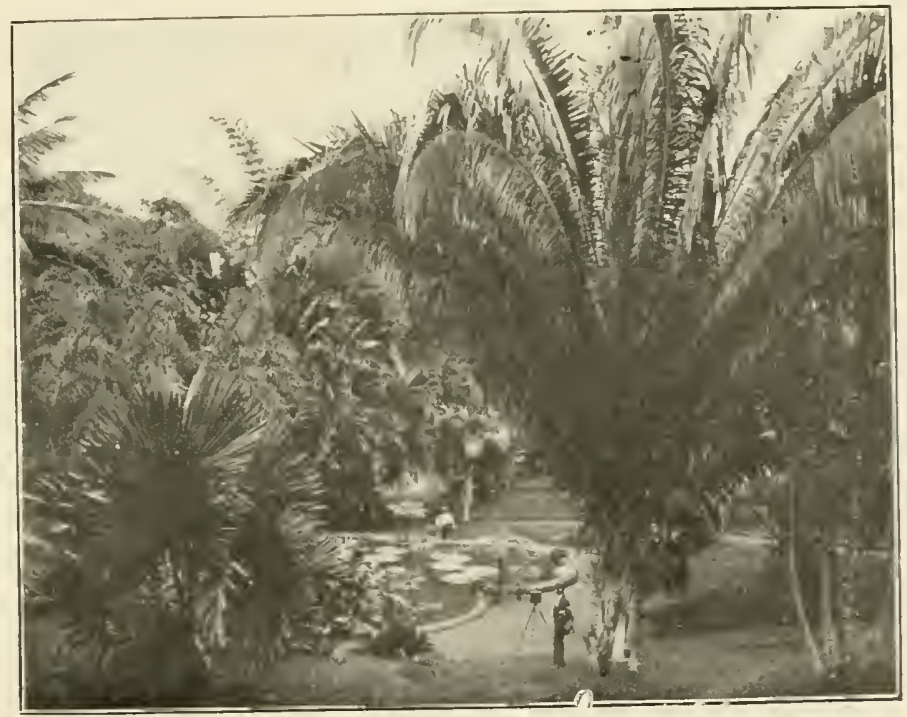

C.ITLETON G.IRIVENS

tough. The trees that we saw were only a remmant of a fine lot. most of which were destroyed by a hurricane that swept the island some little time before. Our guide. by the way. who was a negro foreman at the garden. knew the botanical nanes of all of the plants. and was indeed better posted than any white man that we saw out there.

The elevation of the gardens is three hundred and serenty feet, and there seemed to be plenty of land thereahouts that could be utilized for Heica growing. As labor (negro) is very plentiful, and the laily wage fifty cents. and as in adclition the laws are as yood as anywhere in the Fortl-given no more hurricanes-it would look as if rubler 
might be made to pay. The soil, as already remarked, is in this part of the island, poor, but royal palnus, cocoanuts, ceiba trees, indeed all of the ordinary growtlus of the tropics were in evidence. In addition to this, a few miles took one up in the mountains to almost any climate that one could choose, a valuable adjunct to a tropical plantation operated by a white man.

About six miles from Kingston are the Hope Gardens which are both for botanical specimens and great nurseries. Here are two hun-

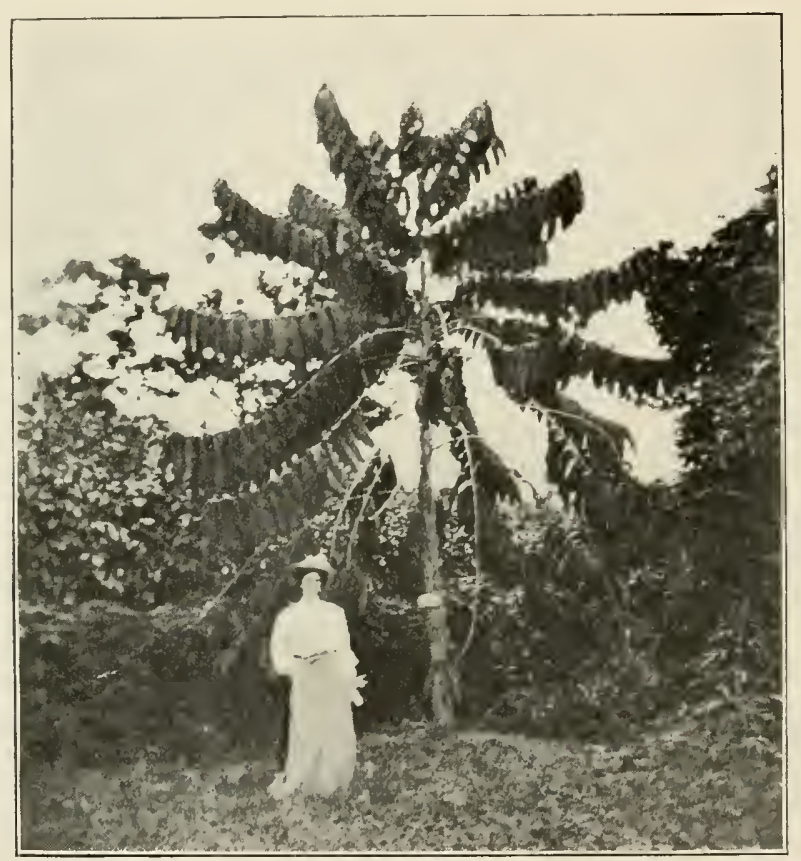

CASTILLOA ELASTICA IN HOPE GARDENS. (TREE 3 YEARS AND 6 MONTHS OLD).

dred and twelve acres, the elevation being six hundred to seven hundred feet. The annual rainfall is $54.2 \mathrm{r}$ inches and the average temperature $77.2^{\circ} \mathrm{F}$. Of the rubber trees that are growing in these gardens only: the Herea and the Castilloa are conspicuous. The former does not seem to be well at all, as it is spindling in its growth and far from vigorous. This is uncloulstedly due to the comparative dryness of the atmosphere. The Castilloa, however, showed a fine growth, due 110 doubt to the fact that it was irrigated. If its vigorous growth means 
added later, it epens up a new fielel for the planting of this tree where there is small rainfall hut plenty of water for surface work.

It may not be generally known, lut Jamaica has its own rubluer producer, a climbing shrub kuww as the llitk Withe. Its botanical name is Forsteronia foribundo (G. Dom) and its stem yields a rubber that as long ago as $\mid S(j)$ wats valued in England at seventy-nine cents a pound. That does not mean necessarily that the product is expral to fine l'arí, although it brought the l'aríl price, for the samples were very dry and showed but little shrinkage. It is a fact, however, that it was a good grade of rubber, and if the reports of the first shippers are accurate, the later is very rich in cautchonc.

To go back a little, the plant is a climbing vine or liane, and grows only in the woods in the interior, chiefly in Manchester and St. Elizabeth comties. The best manner of coagulating was fomm to be the simple application of heat. So far, it has never been exploited commercially, nor is it known whether or not the vine is susceptible of cultivation.

Reverting again to the Castillon, there is saicl to be one plantation of some three thousand trees at the western end of the island, but it is carefully guarded and information refused to all.

I have not touched upon the varied delights of Janaica to the winter tourist, nor described the many minor adventures that three Americans off for a holiclay are sure to discover, for this, after all, is not a holiday tale. It is rather a suggestion to Americans and English that Jamaica is a goorl place in which to "get busy" on the short crop proposition. 

RUBBER CULTURE IN HAWAII 



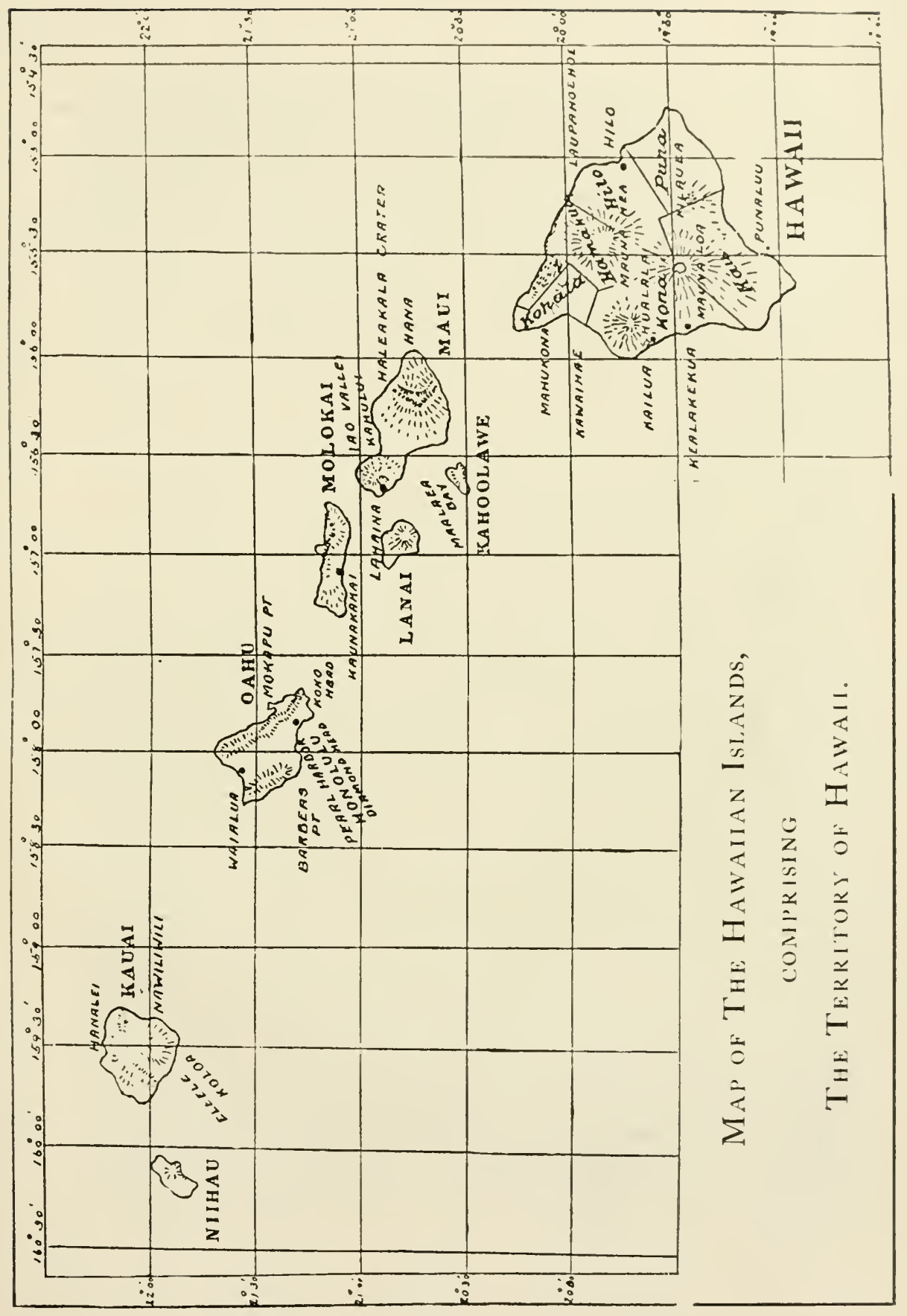




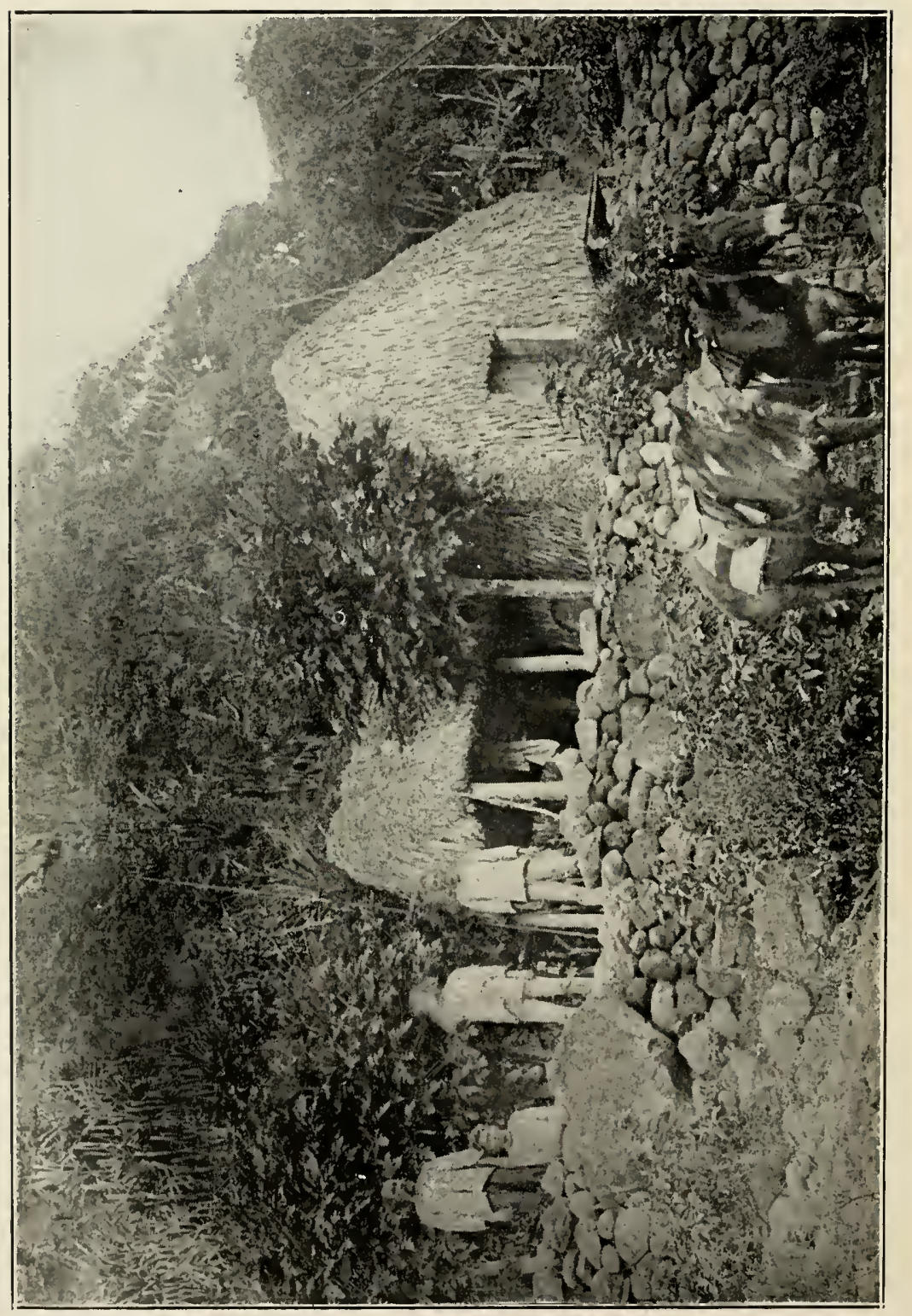




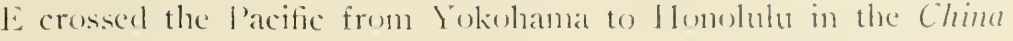
and ats passengers were few I hat a roomy, high-sturleder cabin to myself. Igainst the advice of the stewarel I kept the port open, preferring to take a chance on frowning to one on asphyxiation. Nuch water came in, lunt it diclnt touch we as I slept in the upper bunk, reached by a ladker. and my chanec proved well taken. When we crossed meridian iso we had the somewhat musmal experience of having a day forty-eight hours long. We were given two sumrises, two sunsets, and six square meals, all on liriday, and all on the fifth of the month. Had it been Thurselay or Saturday I should not have cared, lunt I hate fish, and that was certainly a long day.

Onr first sight of the Hawaiian groul came at evening from the "heat lightning" playing over one of the outlying islants, and at claybreak the next morning we were at Itonolulu (pronounced Honolulu by the inhabitants). I say at the place, but not in it, for one of our steerage crowel of Koreans, after troubling the ships doctor by developing granulaterl eyelicks, and threatening smallpox, cane down with a lunge alsscess in the arm pit that the quarantine officials cliagnosed as bubonic. So we waited while they took a section of him ashore, only to return after a few hours with the glad news that it was simply a respectable but angry boil.

After this comforting assurance we went ashore and had tiffin at the elegant Alexander Young Hotel, went out to Wakaki Beach for surf ricling, bought curios, took trolley and carriage rides, and in fact settlerl down to real hard work as sightseers. I an, however, going to put off the story of my own adventures and get right down to the story of Hawaij as it is and as it will be when it gets to he a rubber producer.

To go back a little. the sandwich islands were discovered in I 7 s by Captain Cook, whom the natives believed to be edible, and whom they at once proceerled to get away with. Sone time in the present century they were re-rliscovered ly William I. Gorham of the Gorham Rubber Company, of San Francisco. The natives did not cherish the illusions regarding him that they did toward the former discoverer and he got away with them. When I met him in Honolulu he had just subjugated every trader in the group, and was planning to sell to a srmblicate, enough of his womderful steam hose to run a pipe line from 
the volcano of Kilanea to Ilonolulu, to furnish steam for industrial purposes.

The islands comprising the territory of Hawaii are seven large ones and quite a number of little ones. They are Hawaii, Maui, Oalun, Kanai, Molokai, Lanai, and Niihan. According to the census of 1900

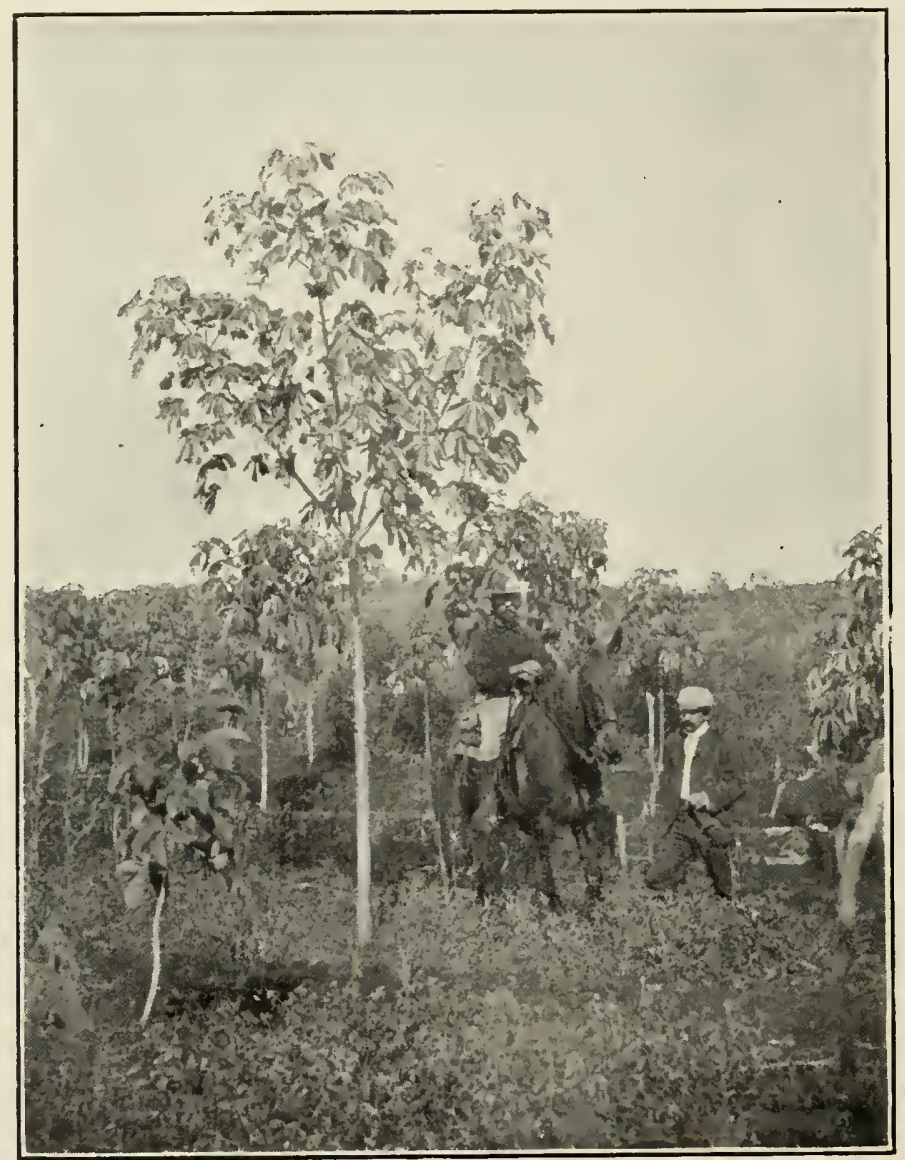

VIEWING YOUNG RUBBER.

they had I54,001 inhabitants. Of these islands, the most densely populated is that of Oahu, which has nearly 60,000 , and it is on this island that the city of Honolulu is situated. The native population to-rlay is small, being less than one third of the total, the predominant races being the Chinese and the Japanese. Probably no country in the world offers a greater variety of beatitiful scenery than does this midocean territory 


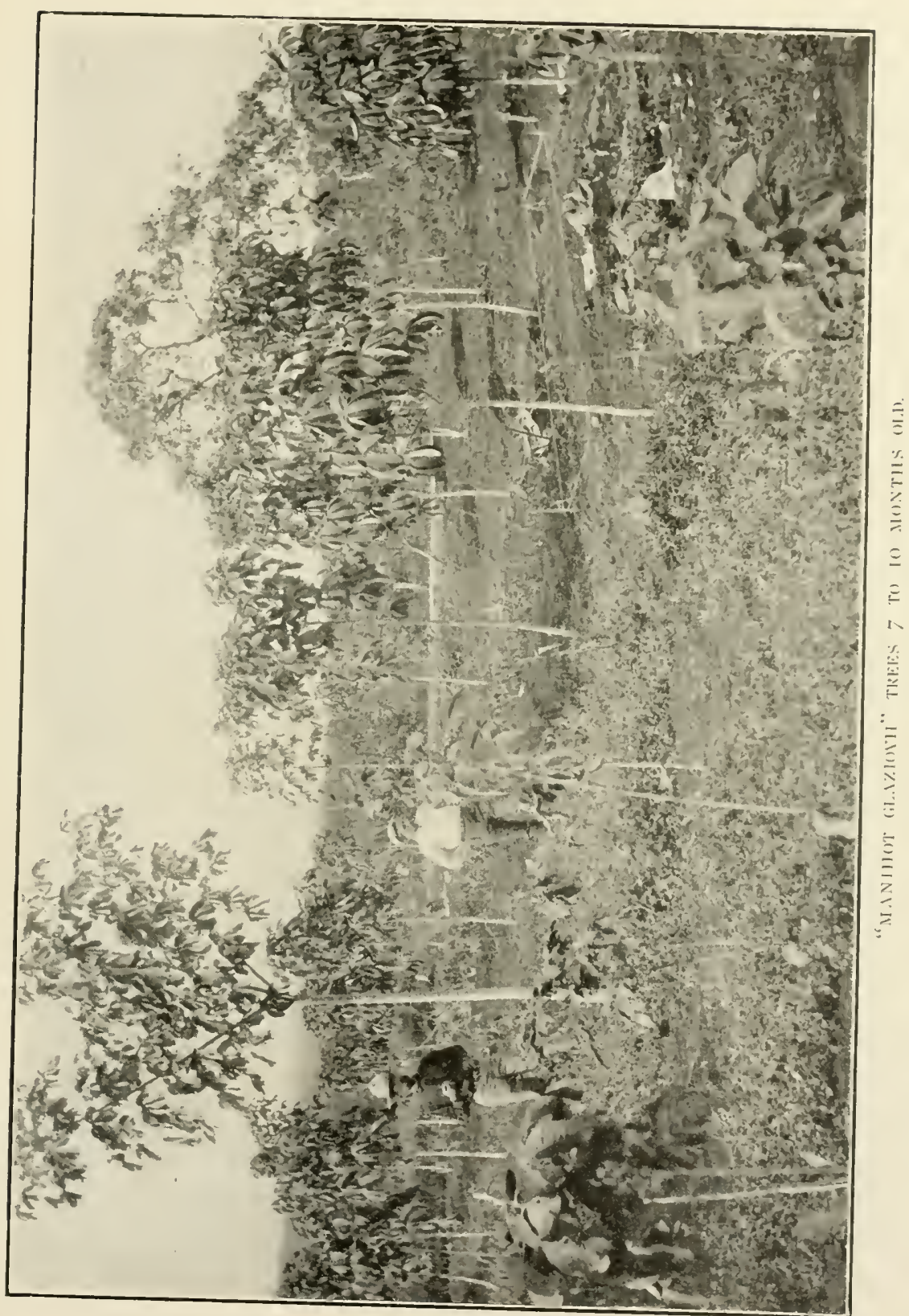


of ours, and not only is the scenery marvelous and the arable land rich and productive, but the clinuate is miformly the finest on earth. The very hottest day that the islands ean furmish will not show a temperature of over $90^{\circ} \mathrm{F}$. and it never gets colder than $55^{\circ}$. (On the mountain tops they have cool nights, occasional frosts, and sometimes a little snow,

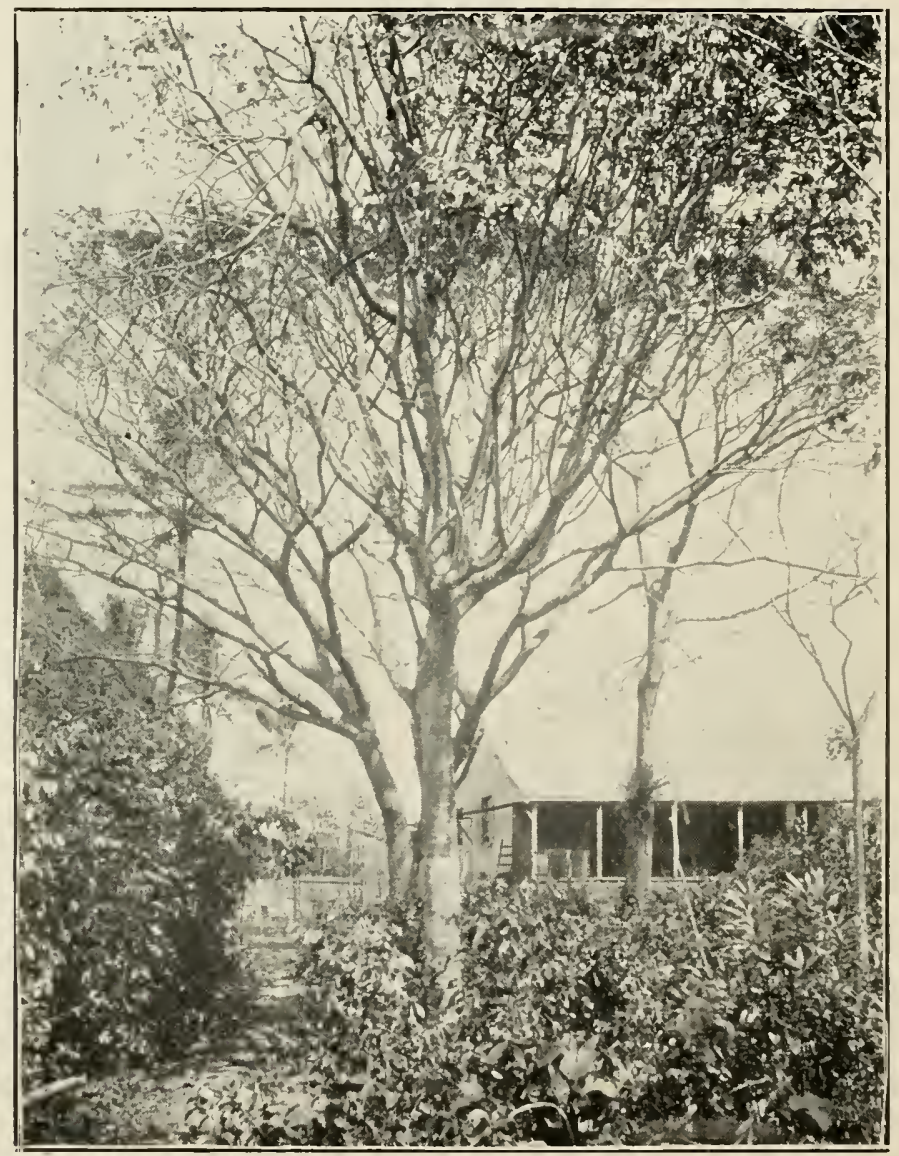

SEIEN YEAR "IIANIHOT" NE.IR NAHIKU LANDING.

but anywhere near the sea level there is heatifiul May weather the rear roumd. It is certainly a fisherman's, huntsman's, bicyclist's, antomobilist's, or general tourist's paradise, and the American people are rapidly waking up to the fact.

Sugar cane, of conrse, is the main erop in the Hawaiian islands. I have forgotten exactly the number of acres but think it is about 200.000 . 


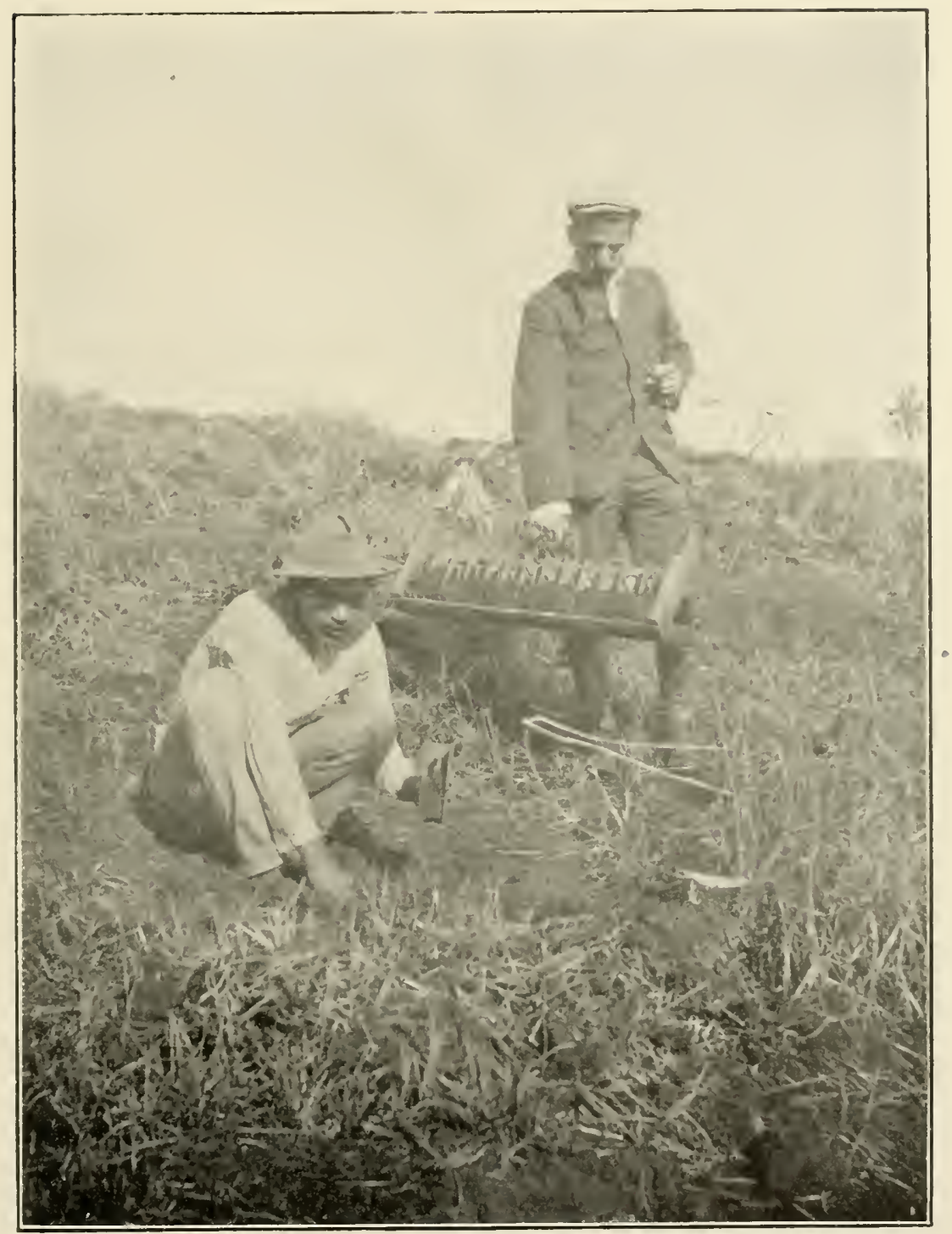

PLANTING ON NEWLY CLE.ARED LAND, NAHIKU PL.ANTITION. 
most of which are tilled by great corporations under their own plantation systems. There are, however, many small planters whose cane finds a ready market at the sugar mills. A great variety of tropical fruits such as pineapples, bananas, alligator pears, oranges, etc., are also grown and a good deal of coffee is raised while the Chinese planter is quite a feature as a rice producer.

It is claimed that there are at the present time something like fo,0oo acres of arable land on the islands, most of it belonging to the government. This may be easily acquired by those who contemplate any sort of planting proposition. Much of this land lies in sheltered valleys, and at the present time it is heavily wooded. The soil being volcanic, except on the coast plains which are of coral origin, the drainage is good and the land fertile. For certain growths, however, fertilizers are needed, and to those who contemplate taking up land in the territory of Hawaii it is strongly urged that they commmicate with the special agent in charge of the Hawaiian Experiment Station at Honolulu, who is a gentlenan of much experience and who is in a position to be very helpful. Exactly what it would cost one to purchase land it is difficult to state. Good sugar land brings from $\$ 25$ to $\$ 60$ an acre, that is, when purchased from private individuals, but bought from the govermment it would cost from sio to $\$ 15$. These holdings are classified, and the conmissioner at Honolulu can give any inquirer full information regarding what is open, conditions for the homestead lease system, right of purchase, leases, cash freeholds, and so on.

I have dwelt at some length upon this for the reason that now that rubber culture has made a leginning in the Sandwich Lslands, and particularly as these islands are now making real progress, many faces will turn towards this I'acific possession of ours, and much agricultura] development will result. It is to be hoped that a large part of this, or at least a fair proportion of it, will be along the line of rubber cultivation. Indeed it wouldn't hurt the writer's feelings a bit if the thousands of acres devoted to the luxury, sugar, were turned within the next five years into the production of the necessity-rubber.

To speak a little further about conditions for the man who wishes to plant rubber or anything else: It will be a satisfaction to many to know that there are 110 snakes or poisonous reptiles of any kind in all the islands. There are no such pestilences as are to be found in other tropical countries, and there isnt a wild beast anywhere there; nor have they yet discovered malaria. Of course there are certain drawbacks. While there are apparently no insects poisonous to man, there are many 


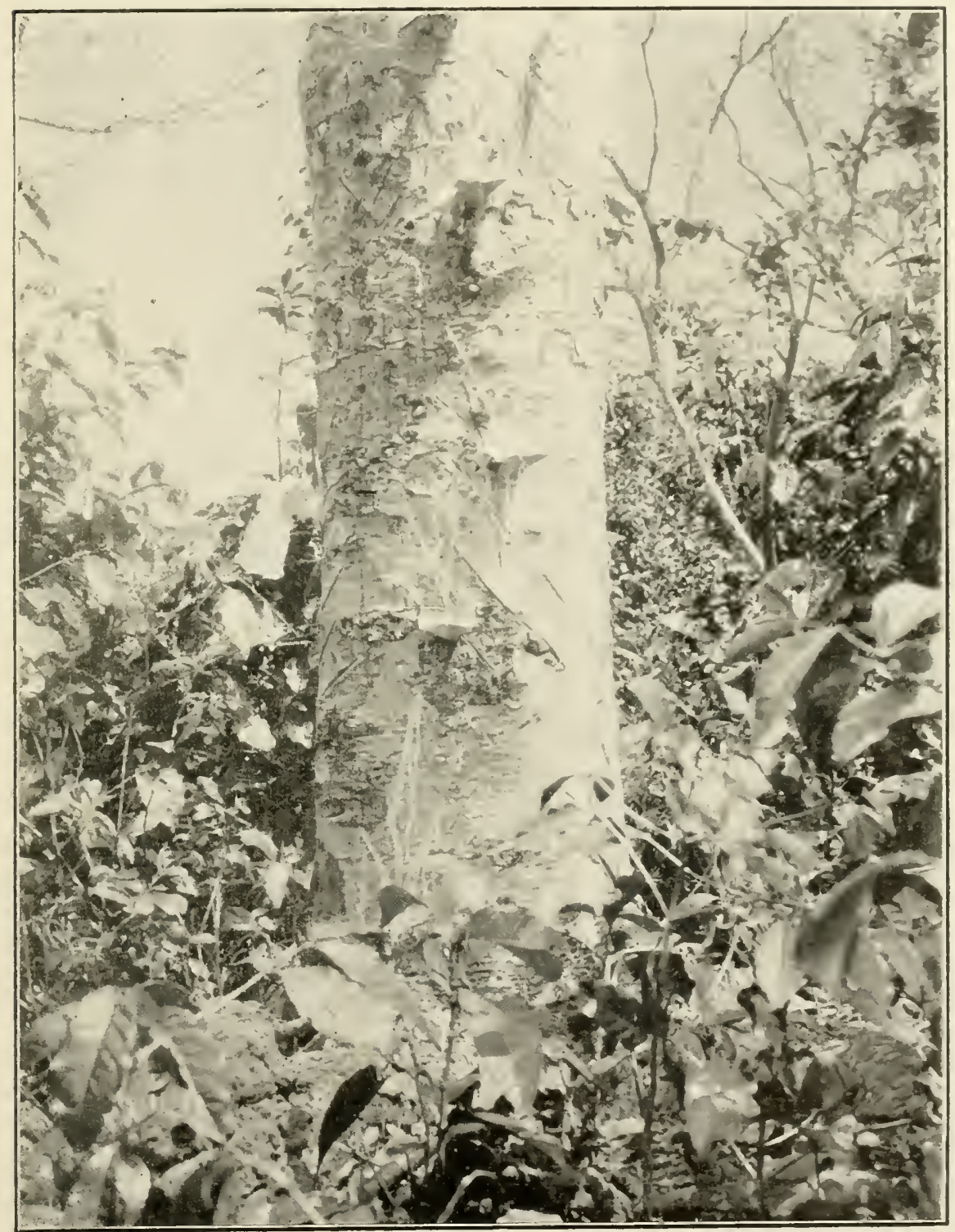

“MANIHOT GLAZIONII," NAHIKU PLANTATION. (22 INCH DIAM.) 
agricultural pests. For example, the fruit inclustry suffers from scale and mealy bugs and sugar planters are obliged to fight the borer and all his kin. Then, too, there are cut worms, plant lice. Japanese rose beetles, and lots of others of the same sort. Whether there is anything that will be injurious to rubber no one knows yet. but it is quite likely that some of the existing insects will adlapt themselves to the rubber situation as it develops. .

My interest in rubber in Hawaii dates back to I89o. during the reign of King Kalakua, with whom I had a most interesting corresponlence. That is, I wrote him some very interesting letters and got no replies. I don't say specifically that that is why he lost his throne, but any student of history knows what has happened to the islands since I received the royal snub.

The defunct ruler, however, went on record as believing that something might be done with the Ficus religiosa and the Ficus Indica which grow there in "prolific profusion.". He also noted that the bread fruit tree (-Artocarpos incisa) produced a gum that for centuries hat been used by his subjects for waterproofing purposes, and which he believed might contain a percentage of rubber. With regard to the cultivation of rubber, he pronised his royal sanction to anyborly witl money to spend to come there and spend it for rubber or anything else.

Somewhere in 1900 the papers in the Far East claimed that the United States govermment was going at once to save $\$ 30,000$,oop that it was then paying for imported rubber, by booming cultivation in Hawaii. The story was, that the mucleus was to be 100,000 rubber trees transplanted from Brazil to the newly acquired territory. Nothing, however. came of this.

It was on the island of Maui that the first real start at rubber planting was made. Seven hundred and sixty square miles has Mani, and a most romantic island it is. It is really two mountains connected by a sandy isthmus, and is wonderfully varied both in clinate and scenery. For example, speaking of climate, one side of the island is dry and barren, but the other, the windward, is exceedingly fertile. This portion, which consists on the lower levels of picturesque valleys. has plenty of rain and rich soil, and it is here that the rubler is being planted, and Ceará (Manihot) was the first tree selected. Rumor has it also that there was something like two hundred acres, part Herea and part Ficus, planted about the sane time, but no record of this planting is at present available. In 1905. however, there was formed the Nahiku Rubber Co., Linited, which took over the plantation containing 

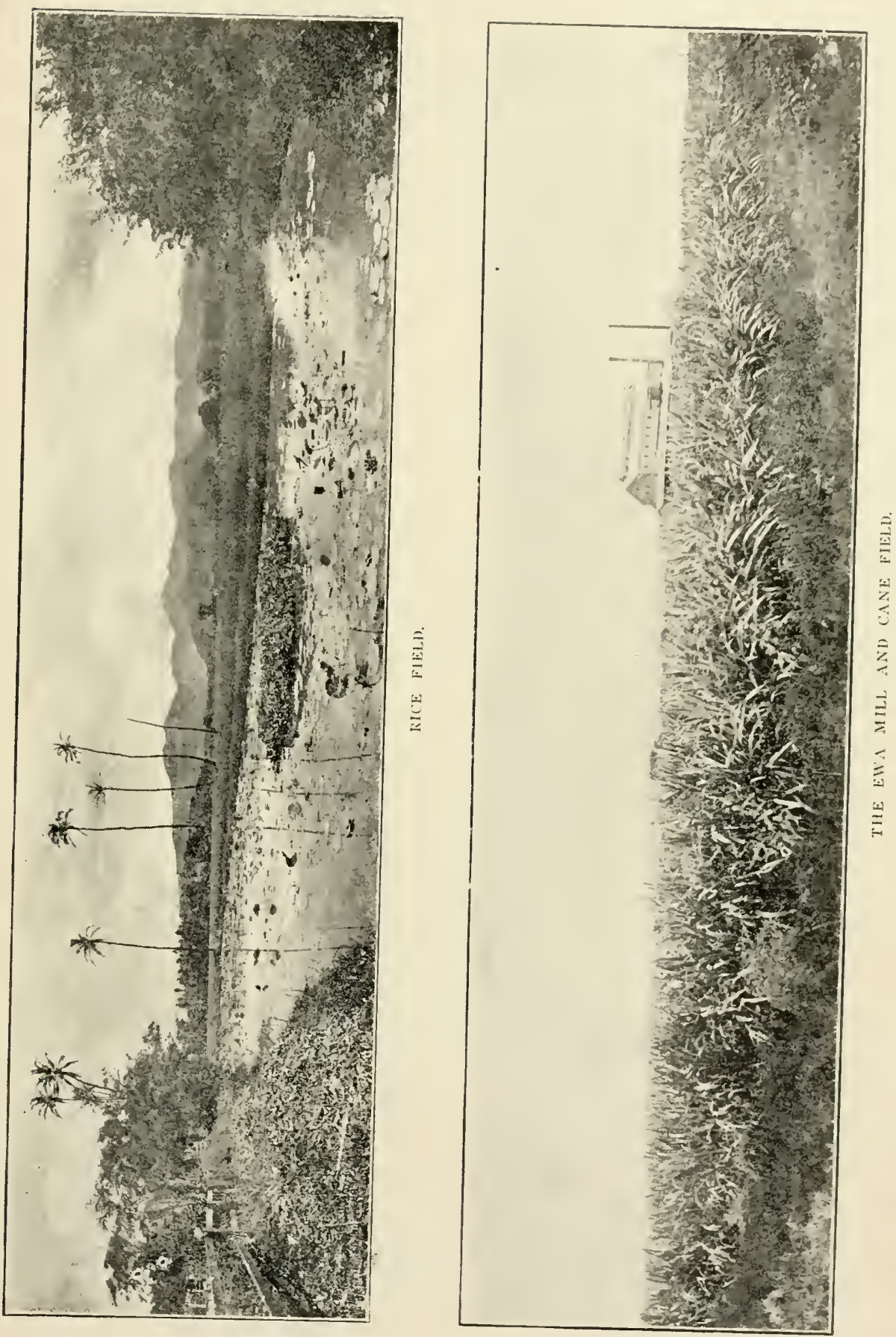
the Ceará trees planted some years before, which although few in number, had not only matured remarkably, but had some exeellent rubber producers. This was rather remarkable, that is, the fact that the trees produced latex, as the rainfall was nearly two hundred and fifty inches. and with the experience of the Ceylon planters before them many thought that the trees would be barren. The reason for this difference perhaps lies in the fact that although the rainfall is great the evaporation is very sudden so that the trees are led to expeet a dronght, which never comes. The same company are also importing seed of the Heica from Ceylon and expect to plant that on a large scale .

With regard to the vield of the Cearí trees in the Naliku plantation, six small incisions produeed an ounce of dry rubber, and this tapping may be repeated once a week through the year.

Mr. Jared G. Snith, who is in elarge of the Hawaiian experiment Station, is authority for the statement that the Manihot trees at Nahiku landing have already produced a pound and a half of dry rubber a year. This assures a good profit. He also mentions the recent incorporation of two more planting companies but gives no particulars further than that they are already planting and the young trees showing marvelous growth. As several leading business men from Hawaii have recently: been in Ceylon and the Straits studying rubber culture it is quite likely that future planting will be in part, at least, of the Herea. It is wortly of note, that the principal rubber planting in Hawaii has been done by settlers from the Lnited States. These are small beginnings, but beginnings all the same. Just keep an eye on T. H. and see if in another decalle she is not producing good rubber as well as furnishing seed for Formosa, the Philippines, Samoa, and other tropical comtries. 


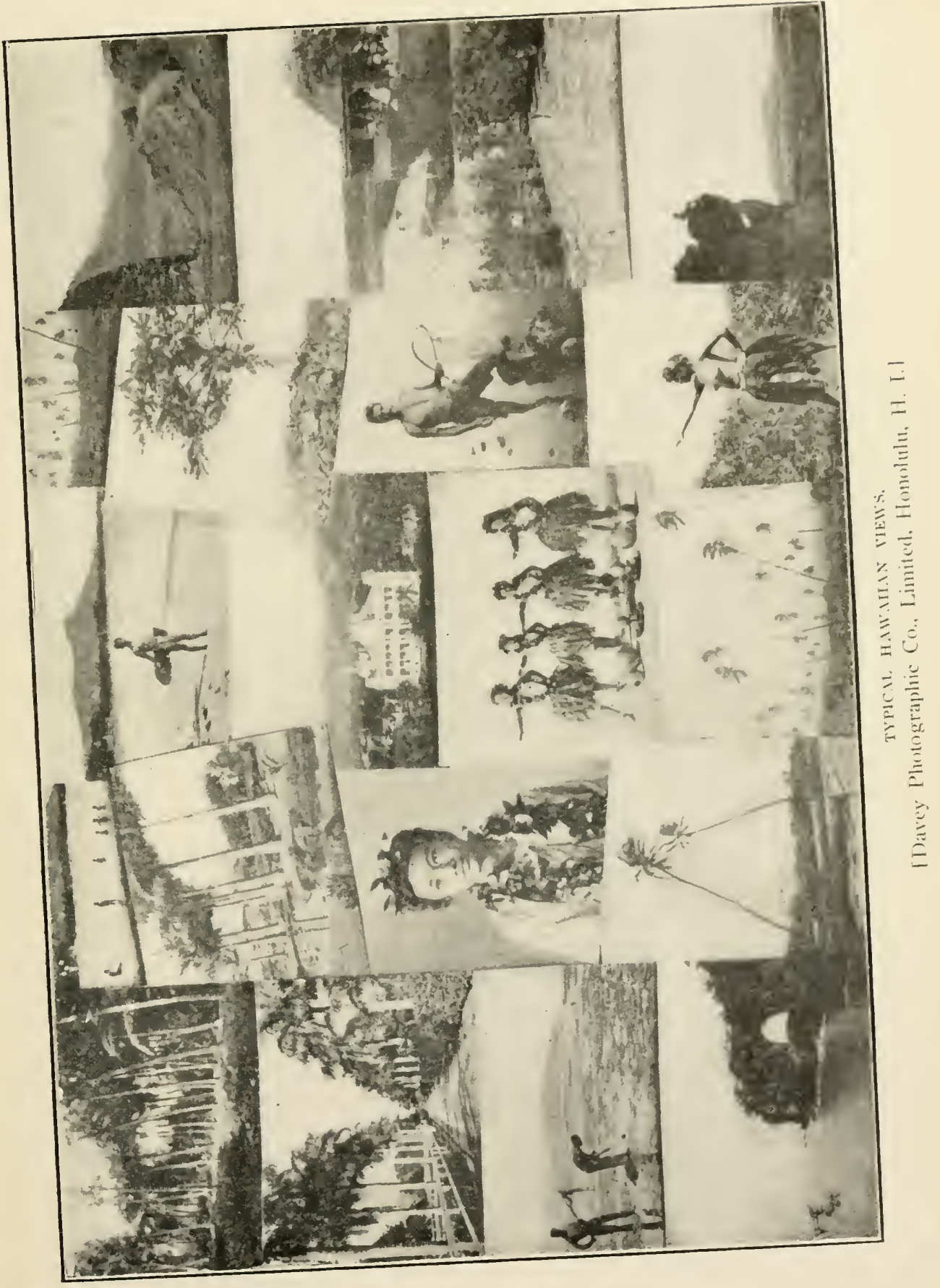






SEP 221805 



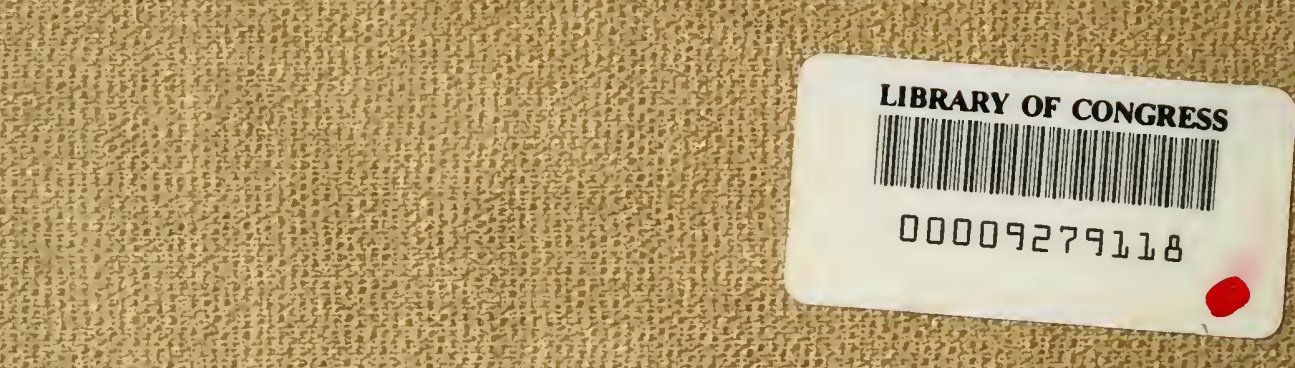

